\title{
GEOLOGY AND RECOGNITION CRITERIA FOR ROLL-TYPE URANIUM DEPOSITS IN CONTINENTAL SANDSTONES
}

FINAL REPORT

\author{
E. N. Harshman \\ and \\ Samuel S. Adams \\ Samuel S. Adams and Associates \\ 2342 Broadway \\ Boulder, Colorado 80302
}

September 1980

PREPARED FOR THE U.S. DEPARTMENT OF ENERGY ASSISTANT SECRETARY FOR RESOURCE APPLICATIONS GRAND JUNCTION OFFICE, COLORADO

This document is PUBLICLY RELEASABLE laryge rethams. Authonzing Official

Date: $03 / 28 / 2007$
UNDER CONTRACT NO. DE-AC13-76GJ01664

AND BENDIX FIELD ENGINEERING CORPORATION SUBCONTRACT NO. 79-296-S

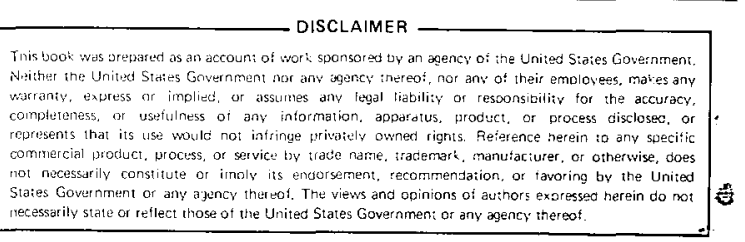

DHSTRBBUTION OF THS DOCLMEHT IS UHLLMITED 


\section{DISCLAIMER}

This report was prepared as an account of work sponsored by an agency of the United States Government. Neither the United States Government nor any agency Thereof, nor any of their employees, makes any warranty, express or implied, or assumes any legal liability or responsibility for the accuracy, completeness, or usefulness of any information, apparatus, product, or process disclosed, or represents that its use would not infringe privately owned rights. Reference herein to any specific commercial product, process, or service by trade name, trademark, manufacturer, or otherwise does not necessarily constitute or imply its endorsement, recommendation, or favoring by the United States Government or any agency thereof. The views and opinions of authors expressed herein do not necessarily state or reflect those of the United States Government or any agency thereof. 


\section{DISCLAIMER}

Portions of this document may be illegible in electronic image products. Images are produced from the best available original document. 


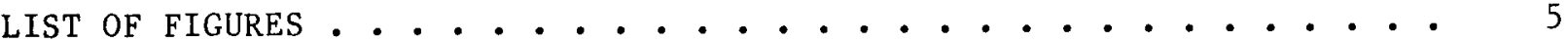

LIST OF TABLES •. •. •. . . . . . . . . . . . . . 9

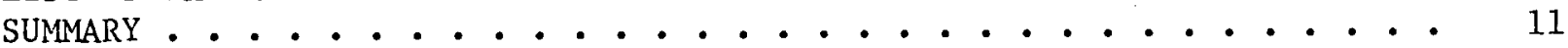

Source of Uranium ...................... 11

Host Rocks . . . . . . . . . . . . . . . . 12

Alteration ...................... 13

Ore Habits . . . . . . . . . . . . . . . . . 14

Recognition Criteria... . . . . . . . . . . . 15

Reflections and Continuing Studies.............. 16

U. S. Potential .................. . 16

INTRODUCTION . . . . . . . . . . . . . . • . . . 17

Objectives . . . . . . . . . . . . . . . 17

Sources of Information . . . . . . . . . . . . . . . 18

Acknowledgements . . . . . . . . . . . . . . 19

GENERAL STATEMENT . . . . . . . . . . . . . . . . . . . 21

TECTONIC AND STRUCTURAL SETTING . . . . . . . . . • • . . 23

SEDIMENTARY SEQUENCES • • • • • • • • • • • • • • • • 25

Black Hills, South Dakota . . . . . . . . . . . . 25

Weld County, Colorado . . . . . . . . . . . . . 28

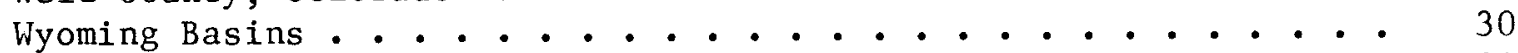

Summary . . . . . . . . . . . . . . . 32

FAVORABLE HOST SANDSTONES . . . . . . . . . . . . . . 33

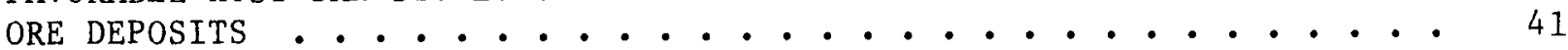

General Description .................... . 41

Shirley Basin Area... . . . . . . . . . . . . . . 44

Gas Hills Area..................... 56

Powder River Basin .................. . . 61

Crooks Gap-Great Divide Basin . . . . . . . . . . . 66

Black Hills Area .................... 78

Other Districts ................... . . . 82

Weld County, Colorado.................. 82

Kaycee Area, Wyoming .................. 84

Lake Frome Area, South Australia . . . . . . . . . 85

ORIGIN OF THE DEPOSITS . . . . . . . . . . . . . . . . . . 91

Source of Uranium and Associated Elements . . . . . . . . . . 91

Character of Mineralizing Solutions . . . . . . . . . . 96

Geochemistry at the Roll Front . . . . . . . . . . . 99

Age .......................... 104

Distribution of Elements................ 107

Pyrite-Marcasite . . . . . . . . ...... 108

Uranium . . . . . . . . . . . . . . . . 108

Selenium ..................... . 108

Vanadium ....................... 113

Molybdenum .................... 113

Iron ........................ 113

Carbon ....................... 113

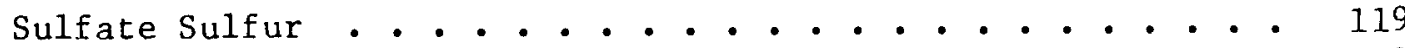

Arsenic ..................... . 119 
$\underline{\text { Page }}$

Beryllium . . . . . . . . . . . . . . . . . .

Copper ....................... 119

Phosphate ..................... . 119

GEOLOGIC-GEOCHEMICAL MODEL . . . . . . . . . . . . . . 125

POST-DEPOSITIONAL MODIFICATION . . . . . . . . . . . . 133

RECOGNITION CRITERIA . . . . . . . . . . . . . . . . . 135

Introduction . . . . . . . . . . . . . . . 135

Evaluation of Recognition Criteria . . . . . . . . . . 138

Description of Recognition Criteria . . . . . . . . . . . 141

Tectonic Structural and Regional Geologic Setting . . . . . . 141

Tectonic Setting. . . . . . . . . . . . . . 141

Structural Setting . . . . . . . . . . . . 147

Sediment Dip . . . . . . . . . . . . . ..... 147

Sediment Source Rocks . . . . . . . . . . . . 148

Uraniferous Province... . . . . . . . . . . 148

Continental Sedimentary Sequence . . . . . . . . . 149

Age .................... 149

Thickness ................... 150

Associated Sediments............... 150

Host Sediments .. . . . . . . . . . . . . . 150

Sandstone-Mudstone Proportions . . . . . . . . . 151

Thickness ................. . 151

Color .................... . . 151

Carbon Content . . . . . . . . . . . . . 152

Volcanic Ash Content . . . . . . . . . . . . 152

Host Sandstone .................... 152

Age .. . . . . . . . . . . . . . 153

Thickness . . . . . . . . . . . . 153

Area .................. . . . 154

Permeability . . . . . . . . . . . . . 154

Composition .. . . . . . . . . . . . . . 154

Depositional Environment . . . . . . . . . 155

Alteration and Mineralization . . . . . . . . . . 156

Alteration . . . . . . . . . . . . 156

Mineralization .............. . . 157

Uranium Anomalies . . . . . . . . . 157

Geochemical Anomalies............ 158

Emanation Anomalies ............. 158

REFLECTIONS AND CONTINUING STUDIES . . . . . . . . . . . . . . . . . 159

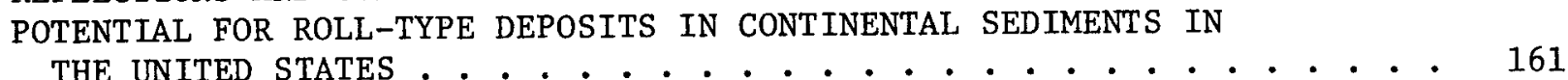

APPENDIX: ESTIMATION OF GEOLOGIC FAVORABILITY FOR THE OCCURRENCE

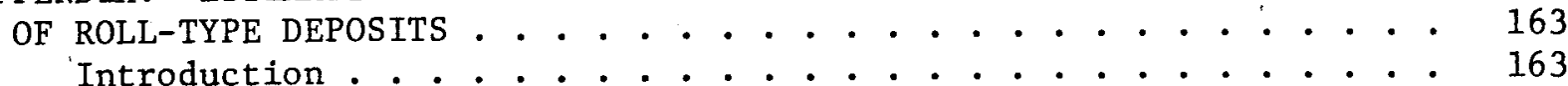

Calculation of Estimated Favorability . . . . . . . . . . 163

Completeness and Confidence of Geologic Data . . . . . . 165

Interpretation of results . . . . . . . . . . . . . 166

Examples of Favorability Estimates for Three Areas . . . . . . . 168

SELECTED REFERENCES . . . . . . . . . . . . . . . . . . 177 


\section{LIST OF FIGURES}

Number

1. Location map and structural setting for the principal uranium districts in Wyoming (modified from Harshman, 1970).

2. Principal stratigraphic units in the uranium districts of Wyoming and adjacent western South Dakota (modified from Harshman, 1968).

3. Diagramatic paleo-environment map and cross section of the Inyan Kara Group and related sediments, Black Hills region, South Dakota (modified from Renfro, 1969).

4. Generalized map showing areal distribution of White River and Arikaree Formations, interpreted from present outcrop distribution, and principal uranium districts (modified from Denson et $a 1,1959$ ).

5. Hypothetical fluvial system traversing a montane basin and associated riverine plain and debouching across a piedmont into a prograding deltaic coastal plain (modified from Galloway, 1979).

6. Geomorphic and sedimentary characteristics of bed-load, mixed-load, and suspended-load channel segments (from Galloway, 1979).

7. Regional setting of the principal uranium districts, alteration tongues and present and inferred Paleocene/Eocene drainage systems, Wyoming intermontane basins (modified from Galloway, 1979).

8. Correlation of terms used to describe various features of roll-type uranium deposits.

9. Simplified cross sections across the edges of altered sandstone tongues showing the most common types of alteration present in some uranium mining districts.

10. Map showing limits of altered sandstone associated with an upper and lower roll-type system in the Wind River Formation, Shirley Basin, Wyoming (modified from Harshman, 1972).

11. Cumulative and frequency distributions of three samples of

sandstone from the ore-bearing sandstone interval, Petrotomics Co. Section 9 pit, Shirley Basin, Wyoming (from Harshman, 1972).

12. Equilibrium relations of 175 samples of mineralizèd sandstone from Shirley Basin, Wyoming" (from Harshman, 1972): 
13. Cross sections at west edge of upper altered-sandstone tongue, Shirley Basin, Wyoming (see Figure 7). Sections A and B are in Petrotomics Co. Section 9 open pit mine. Section C is a simple "C" roll in the Utah International (now Pathfinder) underground mine (from Harshman, 1972).

14. Sma11 ore pods along the bottom of the altered-sandstone tongue about 1200 feet back from the edge of the tongue, Petrotomics Co. Section 9 pit, Shirley Basin, Wyoming (from Harshman, 1972).

15. Summary of mineral deposition in Shirley Basin, Wyoming. Lengths of arrows show relative positions and widths of zones through which minerals were deposited; dashed lines are possible deviations from normal conditions. No scale (from Harshman, 1972).

16. Depositional patterns and distribution of alteration and associated uranium mineralization in the Puddle Springs Formation wet alluvial fan system, Gas Hills uranium district, Wyoming (modified from Galloway, 1979).

17. Cross section through the 4-J pit, Lucky Mc (now Pathfinder) Anderson, 1969).

18. Basin framework, regional facies distribution of the upper

Fort Union-Lower Wasatch(?) fluvial system, and uranium operations, South Powder River Basin, Wyoming (modified after Ga1loway, 1979).

19. Cross section showing the geometry of fluvial channel-fill

facies and stacked alteration fronts. in the southwestern part of the Powder River Basin, Wyoming (modified from Galloway, 1979).

20. Generalized composite cross section of edge of altered-sandstone tongue and orebody, Powder River Basin, Wyoming, showing character of altered sand near roll front.

21. Cross section of Battle Spring, Wasatch, and younger formations in the central part of Great Divide Basin, Wyoming, showing interfingering of the Wasatch and Battle Spring Formations and the tongues of Green River Formation (Tglu and Tg1) within the Wasatch Formation (modified from Pipiringos and Denson, 1970).

22. Generalized geologic map of Great Divide Basin, Wyoming, showing distribution of the Battle Spring, Wasatch and Green River Formations (modified from Pipiringos and Denson, 1970). 
23. Generalized map and cross section of Sweetwater lline area,

Great Divide Basin, Wyoming, showing trend and relative positions of altered-sandstone tongues and the associated mineralized deposits (from Sherborne et al, 1980).

24. Cross section ( $B-B^{\prime}$ Figure 23) through Sweetwater uranium deposit, Great Divide Basin, Wyoming (modified from Sherborne et $\mathrm{al}, 1980$ ).

25. Cross section ( $C-C^{\prime}$ Figure 23) through REB uranium deposit, Great Divide Basin, Wyoming (modified from Sherborne et al, 1980).

26. Cross section ( $D-D^{\prime}$ Figure 23) through eastern part of ENQ uranium deposit, Great Divide Basin, Wyoming (modified from Sherborne et a1, 1980).

27. Cross section (E-E' Figure 23) through the western part of the ENQ uranium deposit, Great Divide Basin, Wyoming (modified from Sherborne et a1, 1980).

28. Generalized geologic map of the Black Hills Region, Wyoming and South Dakota (modified from Renfro, 1969).

29. Cross section in Goshen Hole on the west flank of the Cheyenne Basin, Wyoming (modified from Childers, 1974).

30. Uranium deposits and occurrences of the Frome Embayment and surrounding basement area, South Australia (modified from Brunt, 1978).

31. Uranium deposit locations and structure contours and basement of the Yarramba Channel, South Australia (from Brunt, 1978).

32. Cross sections across the Yarramba Channel, South Australia (from Brunt, 1978). Section locations are shown in Figure 31.

33. Longitudinal cross sections for the Tertiary Beverley uranium deposit, South Australia (from Haynes, 1975).

34. Some possible chemical reactions across a roll front, moving 100 from right to left, during the period of mineralization (modified from Rackley, 1972).

35. Distribution of pyrite-marcasite in roll-type uranium deposits in Wyoming, South Dakota, and Texas (modified from Harshman, 1974).

36. Distribution of uranium as $\mathrm{U}_{3} \mathrm{O}_{3}$ in roll-type uranium deposits in Wyoming, South Dakota, and Texas (modified from Harshman, 1974 ). 
37. Distribution of selenium in roll-type uranium deposits in Wyoming, South Dakota, and Texas (from Harshman, 1974).

38. Distribution of vanadium in roll-type uranium deposits in Wyoming, South Dakota, and Texas (from Harshman, 1974).

39. Distribution of molybdenum in rol1-type uranium deposits in Wyoming, South Dakota, and Texas (from Harshman, 1974).

40. Distribution of total iron in roll-type uranium deposits in Wyoming, South Dakota, and Texas (from Harshman, 1974).

41. Distribution of mineral (MIN) and organic (ORG) carbon in roll-type uranium deposits in Wyoming, South Dakota, and Texas (from Harshman, 1974).

42. Relations among $\mathrm{U}_{3} \mathrm{O}_{8}, \mathrm{CO}_{2}, \mathrm{CaCO}_{3}$ and organic carbon for two traverses across a roll front in the Gas Hills District (from King and Austin, 1966).

43. Distribution of sulfate sulfur in roll-type uranium deposits in Wyoming, South Dakota, and Texas (from Harshman, 1974).

44. Distribution of arsenic in rol1-type uranium deposits in Wyoming, South Dakota, and Texas (from Harshman, 1974).

45. Distribution of beryllium in roll-type uranium deposits in Wyoming, South Dakota, and Texas (from Harshman, 1974).

46. Distribution of copper in rol1-type uranium deposits in Wyoming, South Dakota, and Texas (from Harshman, 1974).

47. Distribution of selenium, vanadium, molybdenum, uranium and pyrite in roll-type uranium deposits (from Harshman, 1974).

48. Possible paths for circulation of mineralizing solutions in the Wyoming basins. Arrows indicate direction of ground water flow (from Harshman, 1972).

49. Postulated Eh and $\mathrm{pH}$ conditions during transportation and deposition of uranium and other elements in the Wyoming basins (from Harshman, 1970).

50. Composite Eh-pH diagram for the principal elements in roll-type uranium deposits, and for copper. Solid phases are underlined (from Harshman, 1974).

51. Hypothetical ground water flow paths for steeply-dipping high permeability unit between two low permeability units (modified from Kreitler, 1979). 
52. Hypothetical ground water flow paths for gently-dipping high permeability unit overlain by low permeability unit (modified from Kreitler, 1979).

53. Recognition criteria net for the rol1-type uranium deposits in continental sandstones.

54. Example of the assignment of weights to recognition criteria using the five criteria that determine Tectonic Structural and Regional Geologic Setting. Tectonic Setting is shown in detail.

55. Schematic relation between calculated favorability for rol1type deposits and the chances of a deposit being present within the area evaluated.

\section{LIST OF TABLES}

$\underline{\text { Number }}$

$\underline{\text { Page }}$

1. Physical and mineralogical data on 39 samples of unaltered, altered, and mineralized sandstone, Shirley Basin, Wyoming (from Harshman, 1972).

2. Chemical analyses of water samples from wells, springs, and drill holes, Shirley Basin, Wyoming (from Harshman, 1972).

3. Analytical data from two, sample suits across altered sandstone tongues and mineralized sandstone, Gas Hills, Wyoming (from King and Austin, 1965).

4. Estimates of the values (Scale +100 to -100 ) for recognition criteria for roll-type deposits for establishing the favorability of the criteria above them in the criteria net (see Fig. 53).

5. Hypothetical recognition criteria values, from four imaginary field areas, for the five criteria that determine Tectonic, Structural and Regional Geologic Setting. 


\section{SUMMARY}

The study of roll-type deposits during the past 20 years, since the first description of a deposit in the United States, has developed general concepts of ore formation which are accepted widely and are compatible with available data. If this were not the case the concepts would not have endured and could not have been so successfully applied to exploration using the relations of altered-unaltered sandstone. The comparative simplicity of the model, and the ease with which it has been applied to exploration have, oddly enough, probably inhibited detailed studies of ore districts that would have provided data now needed for refinement of ore controls for exploration and resource assessment programs. The most thorough study of a roll-type district was that of the Shirley Basin (Harshman, 1972) which is drawn on heavily in this report.

The general concept of roll-type formation provides a strong basis for the development of geological observations and guides, or recognition criteria, for resource studies and exploration. Indeed, industry has been developing and using them for 20 years. As the objective of this study was to identify the most useful recognition criteria and develop a method for their systematic use in resource studies and exploration, the study is best summarized by reference to the important geological observations about roll-type deposits.

Source of Uranium

(1) The source of the uranium in roll-type deposits is still not known with any certainty. Although we have learned to recognize leached granites through uranium-lead studies and have identified the availability and movement of uranium associated with certain tuffs, there is no assurance that the uranium in any of the known districts came from any identified source rock.

(2) A11 roll-type deposits of any consequence occur in proximity to rocks which are considered to contain anomalous concentrations of uranium, generally either granites or tuffs. In some cases, both uraniferous granites and tuffs are present as in the vicinity of the Wyoming basins, increasing one's confidence that these are indeed anomalous regions or, more specifically, uraniferous provinces. The importance of a uraniferous province, i.e. an area in which one or more important rock types contain anomalously high concentrations of uranium, for the formation of uranium deposits is debatable. Even we are not in agreement on whether anomalous rocks are required for the formation of a uranium deposit, or whether the leaching of normal concentrations of uranium from, say, tuffs or granites, is adequate.

(3) The occurrence of tuffs, or their alteration products bentonitic clays, within the major roll-type districts of the United States (i.e., Wyoming and Texas) as well as in association with other major types of sandstone deposits in the Colorado Plateau, presents a strong circumstantial argument that these volcaniclastic and airfall tuff deposits were important to the formation of the deposits. This is our bias, but there remains no proof that this was the case. The resolution of this question is of great importance as it could substantially sharpen the selection of potential areas. 
(4) As with the tuffs, there are uranium deposits which seem spatially related to uraniferous granitic rocks. Although the best examples are not roll-type deposits in the classical sense (for example, the Sherwood Deposit, Washington, and the "basa1" deposits of Japan), the occurrence of these deposits in immediate proximity to underlying anomalous plutons strongly suggests that such rocks are viable sources for uranium in nearby deposits. We accept this as evidence that such rocks could equally supply uranium for roll-type deposits.

\section{Host Rocks}

(1) The favorite host rocks for rol1-type type uranium deposits are arkosic and subarkosic sandstones. Physical characteristics of these sediments, such as their porosity, permeability, and physical suitability, are favorable for the formation of uranium deposits, but much more than that, the sediments reflect an entire tectonic, erosional and hydrologic regime favorable for the formation of rol1-type deposits and discussed below. Some deposits occur within multi-stage quartz-rich sandstones, that form part of fluvial to marginal marine sediments such as occur in the Black Hills, Weld County, Colorado, and the Texas Coastal Plain. These types of targets offer significant exploration opportunities.

(2) Most roll-type deposits occur within interbedded sequences of fluvial sandstones and volcanic-rich sediments which were deposited without major time or erosional breaks. These sequences are typical of Wyoming basins. Other deposits, such as those in the Black Hills and Weld County, Colorado, occur where a volcanic-rich source rock is superimposed upon a reduced aquifer. In the cases cited, the source rock is of Tertiary age, the host rocks of Late Cretaceous age, and the mineralization almost certainly occurred across an unconformity. Such geologic settings are somewhat more difficult to unravel than the typical Wyoming basin target, and therefore they offer some promise for the future. On the other hand, the deposits thus far discovered tend to be of lower grade and continuity, hence less attractive as exploration targets, but we believe that this should not necessarily be the case.

(3) The depositional enviromment of host or potential-host sediments for roll-type uranium deposits exerts an enormous influence on the formation and potential of any roll-type deposits. The manifestations of depositional environment, such as permeability, thickness, areal extent, oxidation state of sediments, the shapes of sand bodies and the sequence of interbedding between sands and mudstones, have all been considered important observations in uranium exploration. However, it has been customary to study these various features in a disjointed fashion that has probably inhibited an understanding of their individual and collective importances and the genetic relations between them. Once the detailed observations have been made, it is important to take the next step and interpret depositional environments. We see considerable value in identifying the environment of sediment deposition as early as possible in any resource study or exploration program, as an important guide to estimating the potential of an area. As discussed at some length in the report, based largely on the important work of Galloway and co-workers, sediments deposited in proximal fan or suspended-1oad depositional regimes are unfavorable for 
major uranium occurrences, but their recognition should guide the search toward the braided, coarser clastic sediments within the mid and distal fan and mixed-load sedimentary environments. This approach relies on customary Iithologic and sedimentological observations augmented by a few additional measurements and interpretations, but it yields a powerful early reconnaissance tool that can be used when only widely-spaced field observations are available.

(4) On a somewhat more detailed scale, the characteristics of the sediments exert strong control on, for example, the location and shape of alteration tongues and their associated roll-type deposits. Some of these sedimentological controls might be predicted, such as at the confluence of two major braided streams or the facies-relations between a coarse arkosic distal fan sediment and fine-grained lacustrine environment. Recognition of such sedimentary features may substantially improve resource studies and exploration. Many sedimentological features which have strong influence on the details of rolltype deposits are of such a local nature as to be unpredictable in reconnaissance work. The development of large organic trash pockets or the diversion of a major channel around a basement high, will produce convolutions in the boundary of an altered tongue and, commonly, accompanying favorable variations in the thickness and grade of the associated deposit. These features may be particularly characteristic of some districts and with experience can be anticipated or perhaps even predicted, but they are too fine scale for consideration at the reconnaissance stage. Examples would include many deposits in the Crooks fap District located where changes in host rock permeability occur, and the lack of ore continuity in the sinuous thin sands of the Lance-Laramie of Weld County, Colorado.

\section{Alteration}

Alteration associated with roll-type deposits is more variable in its habit than the simplicity of the ore-forming mechanism might suggest. The colors, mineralogy, widths, and sequences of alteration types vary significantly between districts and to some extent even within districts. Whereas some of the variations are due to the super-position of late oxidizing events on older alteration patterns related to roll-type deposit formation, there appear to be inherent differences in the alteration associated with ore formation. A11 the patterns can be recognized with some experience, but the variety indicates we have not yet seen all types. This suggests that improved techniques for recognizing alteration, particularly on bases other than color, should be developed so that resource studies and exploration will not be undermined by relations not yet appreciated. It may be that our failure to discover new roll-type districts in recent years is due, in part, to our preoccupation with the easily recognized alteration types of known districts which may well not characterize as yet undiscovered districts. Some of the observed patterns are briefly described below.

(1) The typical hematitic or pink alterations so generally thought of in connection with roll-type alteration is typical of the Powder River Basin and Black Hills deposits as well as those in the Kaycee area, Wyoming, and Weld County, Colorado. 
(2) Alteration described as "bleached" is characteristic of most of the altered sands in the Gas Hills and Crooks Gap Districts, both notably immediately adjacent to the Granite Mountains. The deposits of the Great Divide Basin, thus far only explored in subsurface, are reported to contain cream or gray alteration zones of variable but considerable width between the roll front and a trailing zone of red, tan, and yellowish iron oxides farther updip within the altered sandstone. In the Shirley Basin the altered sandstone is characterized by a greenish-yellow to yellowish color due to the presence of iron-bearing clay and the absence of iron oxides. It is perhaps important that these two districts are marginal to the Granite Mountains, but somewhat more distant than the Gas Hills and Crooks Gap Districts.

(3) The deposits of the Great Divide Basin are unusual not only for their bleached zone but for the sequence of alteration zones present in the altered tongues. In general the pattern, interpreted from drilling data and subject to subsurface confirmation, suggests concentrations of orange feldspar and iron-oxide stained clasts separating the ore of the roll front from the bleached gray or cream zones of the altered sandstone which in turn gives way farther updip within the altered tongue to red, tan, and yellowish sands. These zones are hundreds of feet wide and their widths are believed to be related to sympathetic changes in the width and grade of the deposit itself.

(4) Finally, the deposits of several districts display relatively thin zones of limonite or goethite-stained sands immediately adjacent to the roll front. These zones may be a few inches to several tens of feet wide and are believed to be the product of recent ground water movement which has oxidized part of the deposit, an interpretation which finds basis in strong disequilibrium and particularly in the presence of "no-count ore". Districts displaying these features include those of the Powder River Basin, Gas Hills, Black Hills, and Weld County, Colorado.

Ore Habits

(1) The shape of roll-type deposits is strongly controlled by the hydrology of the host rocks which is in turn controlled by their environments of deposition. In the simpler cases, the shape is related to the hydrology of a single depositional unit, whereas in other cases the presence of angular unconformities, scouring of one channel into another, and related sedimentological features complicate but commonly improve the ore deposit. These features may occur on regional or local scales, hence, may be detectable with reconnaissance scale information or may be defined only during offset drilling.

(2) There are strong indications that the distribution of reductants exerts a strong influence on the formation and habit of roll-type deposits. The deposits in the Great Divide Basin and the Beverley deposit, South Australia, seem to preferentially form tabular uranium occurrences against underlying carbonaceous-rich shales. In the Great Divide Basin crescentic roll fronts are also important, but they have not been recognized in the Beverley deposit. There is also some indication that the deposits in the Gas Hills develop more limb mineralization against carbonaceous-rich shales and the roll fronts in the Yarramba deposit, South Australia occur at the margins of incised and oxidized channels against the enclosing carbonaceous shales. These observations 
suggest that had not the extremely carbonaceous shales been present, at least the habit of the resulting roll fronts would have been different, or perhaps they would have been destroyed altogether. Considerable attention should be paid to the habit of carbon distribution within potential host sediments.

(3) There are also strong indications that the amount and distribution of reductants within the host sands greatly affect the habit of ore. In the Great Divide Basin, for example, the width of the various alteration zones of the altered tongue seem to relate to the width and tenor of the roll front. In the Powder River Basin, it has been reported that where the roll front is wide it tends to be of low grade and vice versa. Although data is lacking, it seems likely that the width-grade relations within a roll front will be controlled by the reducing characteristics of the unaltered sandstone, the rate of ground water flow, and the oxidizing capacity of the introduced ground waters. Abundant organic material and/or pyrite and slow ground water flow rates (influenced by low dips and restricted transmissivity) should yield sharp, narrow, high-grade deposits. By contrast, the combination of low concentrations of reductants, high transmissivity, and steeper dips should produce broader more diffuse roll fronts. Insofar as these features are controlled by measurable characteristics of the host sediments, improved prediction of ore types should be possible, but data to confirm these suppositions or develop better ones are not currently available.

\section{Recognition Criteria}

(1) A method is presented for organizing geologic observations into what we refer to as recognition criteria. The use of such observations to draw inferences about favorability has been employed for decades, but in an informal way. Informal methods will continue to be part of any interpretive process, and we believe this to be appropriate. We see merit, however, in attempting to identify those geologic criteria that are the most important guides to rolltype deposits and establish at least their relative importances.

(2) Recognition criteria are presented for the appraisal of areas favorable for the occurrence of roll-type deposits. Each criterion has various conditions or states of relative favorability and unfavorability, and most incorporate reference to several types of geologic observations. None of the criteria are new; in fact, they seem pedantic and shopworn. However, in the process of developing this report, in particular while attempting to establish the relative importance of the various criteria, we found ourselves thinking about many of them differently than in the past, and we suspect that some readers may have similar experiences. The recognition criteria have not been developed for those geologists expert at roll-type deposits who have been using them "in their heads", but to lend some consistency to studies performed by those with less experience.

(3) The relative importances assigned to the various recognition criteria are subjective judgements and we would have little argument with comparable but different numbers. On the other hand, to accept substantially different values would require, for us, the presentation of data different from that which we used. 
(4) A method is also presented for accumulating the favorability of numerous recognition criteria in a simple but systematic fashion so that the relative favorability for a roll-type deposit can be estimated.

(5) The methods presented for using recognition criteria suffer from several shortcomings including the non-independence of the recognition criteria themselves. While these problems detract from the mathematical and logical rigor of the method, we suspect that the errors introduced are well within errors associated with the collection and interpretation of the geologic data itself. Our attempt has been to present a system which is compatible with the quality of existing data but at the same time provides a useful mechanism for working with the large and complex volume of data and interpretations.

(6) By tying the recognition criteria as closely as possible to documented geologic observations, the results should be useful as a checklist for resource studies and exploration and a basis for improving upon current concepts and methods. This first attempt undoubtedly has numerous limitations which hopefully will stimulate improvements by others.

Continuing Studies

Throughout this compilation and interpretation of data for roll-type deposits, we have been impressed with the fragmentary nature of information on this important type of deposit. We have, therefore, included suggestions for continuing studies that might improve the evaluation of potential sources and host rocks.

\section{U. S. Potential}

The numerous manifestations of the roll-type mechanism that lead to the formation of uranium deposits makes us optimistic that discovery of new deposits and new districts will occur. The preoccupation with settings of the Wyoming Tertiary basin-type has inhibited the search in areas with less obvious potential. These areas will, nonetheless, contain manifestations of the recognition criteria discussed in this report, but will not be the obvious shallow, exposed types of targets typical of the Wyoming basins. The new environments will probably yield smaller deposits, but it would be unjustified to expect that they will necessarily be low grade, in fact, some of them may be substantially better than the customary roll-type deposits. One has only to reflect on the grade and size of the unusual Lisbon Valley District to tarnish significantly the glamour of both typical roll-type deposits and the deep deposits of the Grants Mineral Belt. The formation of roll-type deposits is controlled by several independent and several related variables, and there should be many variants on the ore-forming scheme that have not yet been widely encountered.

It is our hope that this effort will rekindle interest in the re-evaluation of both known roll-front regions and those which, based on imaginative interpretation of the criteria presented, might join the ranks of the productive. 


\section{INTRODUCTION}

This report reviews the geology, genesis, and controls of roll-type uranium deposits for the purpose of describing those geologic recognition criteria which seem most useful for the evaluation of areas with potential for new deposits. The review on which the report is based is part of the National Uranium Resource Evaluation (NURE) program of the U. S. Department of Energy (DOE).

Ro11-type uranium deposits will be a major factor in the domestic uranium industry constituting as they do between 40 and 50 percent of domestic reserves and an additional 25 to 35 percent of current estimated U.S. resources producible at forward costs of $\$ 50$ or less (DOE, 1979). The importance of these deposits has led to intensive exploration activities over the past 15 years, from which numerous discoveries have resulted and much has been learned about the characteristics and distribution of these deposits.

The literature on roll-type deposits is replete with descriptions of aspects of individual deposits and interpretations of their genesis and controls. On the other hand, there is a paucity of thorough, systematic studies of individual deposits or comparisons between different deposits. Much of the requisite data on the composition, mineralogy, etc., of the host and probable source rocks are lacking and can only be accumulated through carefully designed geologic studies of considerable duration. This review and synthesis of available data on the better-described areas, focusing on the similarities and differences of individual deposits and districts, has attempted to develop an improved set of geologic recognition criteria for purposes of resource evaluation and exploration, augmented wherever possible by information from unpublished sources.

The project was originally proposed in 1978 by the junior author as one part of a project to review six major types of uranium deposits considered to have significant potential for discovery in the United States. It was the intent to retain the services of six experts, each intimately familiar with one of the deposit types. The contract was awarded in November 1979, and the senior author was engaged to prepare the majority of the descriptive and interpretative material. The junior author edited and collaborated on portions of the manuscript, and developed the recognition criteria section, which we then jointly applied to the roll-type deposits.

\section{Objectives}

The objective of this study is to contribute to the NURE program by providing a more comprehensive synthesis of the geology of roll-type deposits and a more systematic methodology for handling geologic information. The mission of the NURE program is to prepare more reliable and comprehensive uranium reserve and resource estimates for the United States. Preliminary reports have presented interim estimates of reserves in a series of cost categories, and estimates of resources in certainty categories (probable, possible, and speculative). Reserve estimates are based almost entirely on company data supplied to the 
Department of Energy. By comparison, estimates of undiscovered resources are based upon: (1) geologic judgement, which compares the geologic characteristics of known uranium districts with areas perceived to have uranium potential, and (2) assigns to the latter resource-potential estimates based upon the general geologic similarities, the comparative areas involved, and the grade and tonnage characteristics of the known district.

The uncertainties associated with resource estimation are considerable and generally accepted procedures for preparing such estimates have not been available. One major uncertainty, to us the first and most fundamental uncertainty, is the selection, collection and interpretation of geologic information. Whereas the subjectivity of comparing geologic characteristics of known deposits and districts with untested areas will never be entirely eliminated, it seems that the process might be improved by attempting to identify the most critical geologic observations, herein referred to as recognition criteria, and then to estimate and accumulate the degree of geologic similarity for these observations.: This possibility became an important part of the objectives of this study which may be summarized as follows:

(1) Review the geology of the principal rol1-type districts through descriptions of the geologic characteristics of each and identify their important similarities and differences.

(2) Review concepts of genesis and ore control, emphasizing the development of general principals based upon similarities between individual

$\therefore$ districts and differences which set districts or aspects of districts apart from the typical deposits.

(3) Establish if significantly different types of roll-type deposits exist and if new variants are likely to be discovered.

(4) Identify geologic characteristics which can be expressed as recognition criteria, the presence or absence of which most strongly affects the favorability or potential of an area for the occurrence of a rolltype deposit.

(5) Develop a simple method for ranking the relative importance of the recognition criteria.

(6) Develop a method for accumulating the favorabilities derived from individual recognition criteria so as to estimate the favorability for a roll-type deposit in a reasonably systematic but practical fashion.

Sources of Information

The descriptive and interpretative material in this report has been taken from published and unpublished reports on the principal roll-type uranium deposits in the Wyoming Tertiary basins and deposits elsewhere, obtained through discussions with geologists with first-hand knowledge of these deposits and through the writers 'interpretations and personal investigations of uranium deposits in the Wyoming basins. Although some minor deposits are discussed, much of 
the data concerns the five major rol1-type districts for which the available data base permits at least a reasonable description of the deposits.

Through numerous discussions with both exploration and research geologists, we have attempted to accumulate as much information and informed opinion as possible. In some cases previously unpublished data was made available to us and is included in the text. In numerous other cases, we found that data simply does not exist even for the seemingly most basic questions, such as uranium mineralogy. We have attempted to be thorough in our coverage of the domestic roll-type districts, but have included references to foreign deposits only where substantive data are presented. For example, we make reference to certain deposits in Australia which are well described. The literature on deposits in Russia, by contrast, has had considerable impact on the geochemical interpretation of roll-front deposits in this country but deposit descriptions themselves are less complete.

Our emphasis has been on the collection and review of well-documented data and observations so as to present a reliable data base for the interpretation of ore genesis and controls and the preparation of broadly useful recognition criteria. Attempts to develop more specific and refined criteria have not met with great success, mostly because of the lack of data for most deposits, but also because of the differences between deposits.

Less attention is paid to some of the details of ore solution chemistry and ore precipitation than some readers might prefer. Many topics, such as the nature of soluble uranium-organic complexes, although poorly understood, contribute relatively little uncertainty to exploration and resource studies, and have not been considered. Similarly, a thorough discussion of the relative importance of carbon-bearing versus carbon-free sulfide systems in roll-type formations seems to us an unnecessary pursuit at this time. Field and laboratory data demonstrate the dominance of the carbon-bearing systems, as well as the effectiveness of relatively carbon-free systems. The real questions, in our minds, are the effects of variable amounts of carbon and pyrite and differences in their distribution on the development, grade and tonnage characeristics of roll-type deposits, and here the basic data are generally lacking.

\section{Acknowledgments}

The writers wish to acknowledge the contributions of their many associates in the uranium industry whose ideas, observations, and data through the years have directly or indirectly become a part of this report. We have included many in the 1 ist of selected references, but there are additional dozens who contributed during discussions, field trips, and mine visits.

More specifically, we wish to thank those who gave freely of their time in editing the manuscript, particularly Merle Crew, Department of Energy; M. O. Childers, Power Resources Corporation; S. R. Austin, Robert Horton, C. A. Jones, and others, Bendix Field Engineering Corporation; J. F. Davis, Rocky Mountain Energy Company; and H. C. Granger and E. S. Santos, U. S. Geological Survey. Their comments substantially: improved the report, but they do not necessarily endorse its contents. Jo Ann Fankhauser skillfully prepared numerous drafts of the manuscript and performed innumerable other tasks essential to the completion of this contract. 
The term "roll-type" deposits has been applied to epigenetic accumulations of reduced uranium and other minerals located along the interface between altered and unaltered portions of a sandstone host rock. The ore generally crosscuts, but in part may be peneconcordant with sedimentary features of the host. The orebodies are broadly crescentic in cross section but may exhibit many irregularities in outline. Some geologists consider all uranium orebodies in sandstone in the western United States to have had a similar genesis, and they point out the many similarities between the various types described by earlier investigators. We feel that the deposits that have become known as "rolltype" have certain characteristics that suggest a distinctive genesis and thus we prefer to consider them as occupying a separate niche in any classification based on genesis and/or physical characteristics. The Texas Coastal Plain deposits are of a roll-type, but they will be discussed in a separate report titled, Geology and Recognition Criteria for Sandstone Uranium Deposits in Mixed Fluvia1-Shallow Marine Sedimentary Sequences, South Texas.

The descriptive and interpretative material in this report, including the recognition criteria, is based principally on the following mining districts that are shown in Figure 1:

(1) Shirley Basin District, Wyoming

(2) Powder River Basin Districts, Wyoming

(3) Gas Hills District, Wyoming

(4) Crooks Gap-Great Divide Basin District, Wyoming

(5) Black Hills District, Wyoming and South Dakota

Geologic data on several other districts were reviewed. Some of those with characteristics of roll-type deposits are discussed in this report. Those districts that failed to meet the diagnostic criteria of having the principal orebodies limited to an interface between altered and unaltered sandstone host are not discussed in this report. 
Selected references: Houston, 1969; Keefer, 1970; Love, 1970; Lipman and others, 1972; Gilluly, 1973; Tweto, 1975.

The major roll-type deposits discovered to date are found in intermontane basins filled with clastic sedimentary rocks (Fig. 1) and distant from the margins of continental blocks. The basins range in size from a few hundred square miles (Shirley Basin) to several thousand square miles (Powder River Basin). The basin centers are generally from a few to a few tens of miles from the granitic cores of major mountain ranges that flank them. Tectonic and erosional processes were involved in basin formation and subsequent basin filling, but in most places tectonism did not greatly affect the basin fill that is host for the uranium ore deposits.

The basins in which roll-type deposits are found are all related to the Laramide orogeny, and most of them were developing, as we know them today, by Late Cretaceous or Early Paleocene time. Subsidence, uplift, and displacement along faults at the margins of some basins continued through most of the Tertiary and influenced the type of sediment deposited in the basins.

Two possible mechanisms have been proposed to explain the orogenic forces that produced major tectonism and magmatism distant from the continental margins. Lipman and others (1972) proposed a model that relates the Laramide orogeny in the Rocky Mountain province, of which the Wyoming intermontane basins are a part, to a suspended subduction zone extending several hundred miles westward from the east front of the Rocky Mountains. Gilluly (1973) rejects the concept of a subduction zone so far from continental margins and proposes instead that orogeny was caused by inhomogeneities in the crust and mantle and by irregularities in the zone over which the continent drifted.

Tweto (1975) in a study of the Rocky Mountains in southern Wyoming, Colorado, and northern New Mexico, found that tectonic features controlling many of the uplifts date from the Paleozoic and Precambrian and that vertical forces reactivating old structures rather than horizontal forces played the major part in the Laramide orogeny. He believes that there is little support for the concept that horizontal forces were responsible for the Laramide orogeny and magmatism, but he makes no choice between the Lipman and Gilluly models.

Sma1ler but significant roll-type uranium deposits are found in Cretaceous sandstones on the west flank of the Black Hills uplift and on the west side of the Denver Basin in Weld County, Colorado. Although the host rocks are older than those in the Wyoming basins, the uranium deposits are believed to be related to events of Laramide and slightly younger age. 


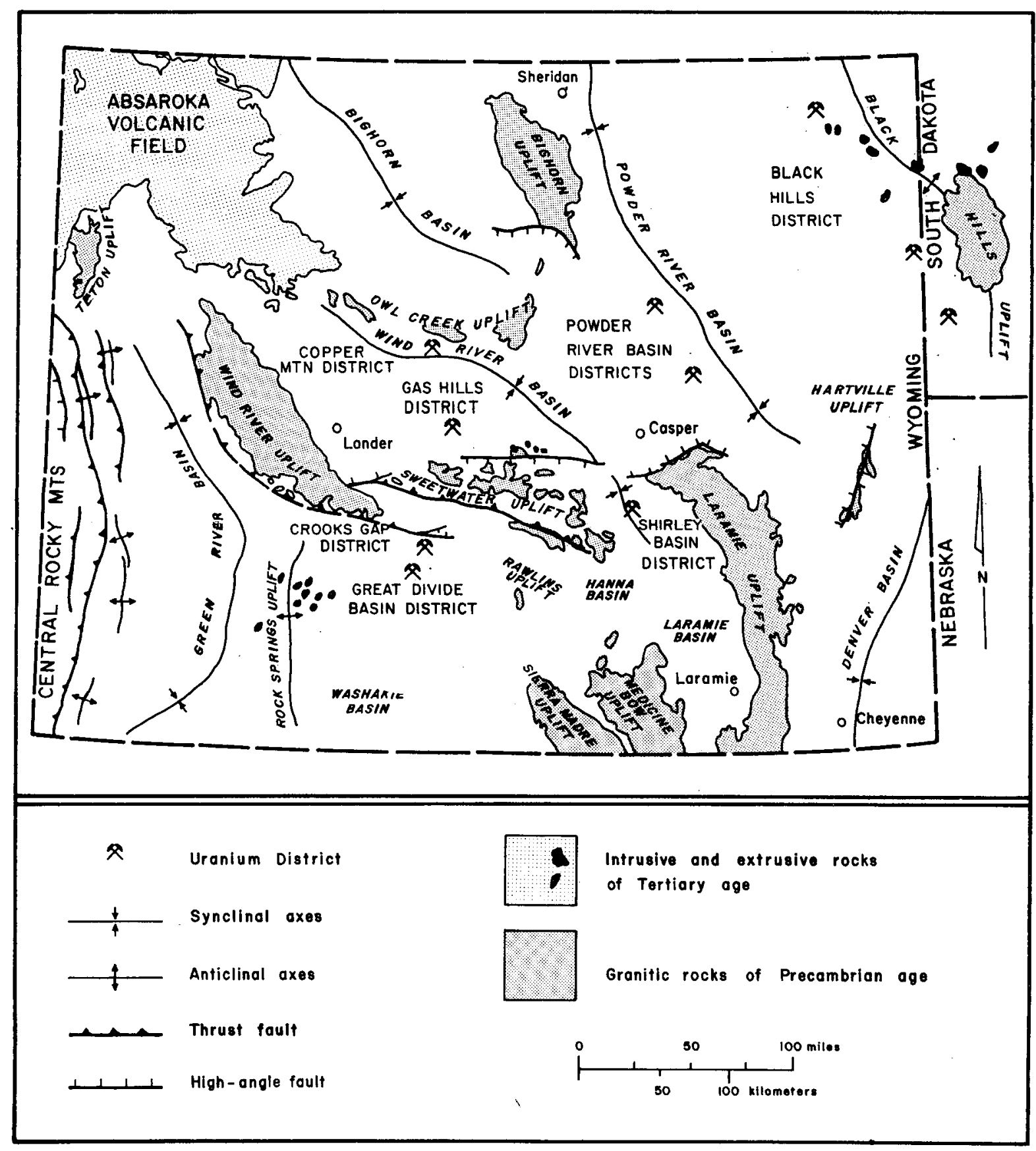

Figure 1. Location map and structural setting for the principal uranium districts in Wyoming (modified from Harshman, 1970). 
Black Hills, Wyoming-South Dakota

Selected references: Waagé, 1959; Robinson and others, 1964; Hart, 1968; Renfro, 1969; Gott and others, 1974.

The host rocks for the deposits discussed in this report range in age from Cretaceous (Black Hills) to Early Eocene (Shirley Basin, Gas Hills, Powder River Basin, Crooks Gap-Great Divide Basin). The principal stratigraphic units are shown on Figure 2. The deposits of the Black Hills district, Wyoming-South Dakota, and Weld County, Colorado, occur, respectively, in older and younger Cretaceous sediments whereas the more important deposits of the Wyoming Basins occur in Tertiary sediments.

The host rocks for the uranium deposits in the Black Hills area are sandstones of the Lower Cretaceous Inyan Kara Group. The Group is underlain by the continental siltstones and claystones of the Jurassic Morrison Formation and overlain by the Lower Cretaceous marine Skull Creek Shale. There is no regional stratigraphic break between the Inyan Kara and the underlying Morrison Formation, nor is there one between the Inyan Kara and the overlying Skull Creek Shale; the Group appears to have been deposited during a period of transition from continental to marine conditions (Fig. 3). The Inyan Kara Group ranges in thickness from 300 to 600 feet.

Waagé (1959) has divided the Inyan Kara Group into two formations--the Lakota Formation (lower) and the Fall River Formation (upper). Both Renfro (1969) and Hart (1968) have described the stratigraphy in relation to the ore deposits in the Black Hills area and the descriptions that follow are based largely on their publications.

The Lakota ranges in thickness from about 200 to 500 feet. It is non-marine, has a poorly defined contact with the underlying Morrison Formation, and in many places the contact must be arbitrarily picked. The Lakota is a sequence of fine- to coarse-grained, buff to white channel sandstone and conglomeratic sandstone, and interbedded varicolored siltstone and claystone. The basal part of the sequence consists of thin, discontinuous, dark gray to black, sandstone and claystone containing organic matter as humates and thin seams of low-grade coal. These beds grade upward into, and in some places are cut out by, a sequence of intertonguing sandstones, dark gray and composed of chert, quartzite, and quartz grains. These sandstones contain considerable organic matter and interstitial pyrite. The sandstones range from fine-grained and silty to coarse-grained and conglomeratic. Some are well cemented, others contain little cement and are friable. The claystones range from hard and silty to semi-plastic; many are bentonitic. Some of the sandstone lenses are broad and sheet-like, others are long and narrow. These massive sandstones thin from southeast to northwest, indicating that the serliment originated in an uplifted area to the southeast of the present Black Hills. The thinning of these sandstones accounts for the thinning of the Lakota Formation from southeast to northwest. 


\begin{tabular}{|c|c|c|c|c|c|}
\hline \multicolumn{3}{|c|}{ Geologic time units } & $\begin{array}{c}\text { Centrat and southeastern } \\
\text { Wyoming area }\end{array}$ & \multicolumn{2}{|c|}{ Black Hills area } \\
\hline \multirow{8}{*}{$\begin{array}{l}0 \\
0 \\
0 \\
0 \\
0 \\
0 \\
0\end{array}$} & Quaternary & $\begin{array}{l}\text { Recent and } \\
\text { Plei stocene }\end{array}$ & \multicolumn{3}{|c|}{ Stream alluvium and terrace gravels } \\
\hline & \multirow{7}{*}{ Tertiary } & Pliocene & Ogallala Fm & \multicolumn{2}{|l|}{ Ogallala Fm } \\
\hline & & Miocene(?) & Browns Pạk Fm & \multicolumn{2}{|l|}{ (Absent) } \\
\hline & & Miocene & Arikaree Fm & \multicolumn{2}{|l|}{ Arikaree Fm } \\
\hline & & Oligocene & White River Fm & \multicolumn{2}{|l|}{ White River Fm } \\
\hline & & & Wagon Bed Fm & \multirow{2}{*}{$($ Absent) } & \multirow{2}{*}{ ' } \\
\hline & & Eocene $* *$ & Wind River* and Wasatch* Fms & & \\
\hline & & Pal eocene & Fort Union Fm & \multicolumn{2}{|l|}{ Fort Union* $\mathrm{Fm}$} \\
\hline & \multirow{9}{*}{ Cretaceous } & \multirow{6}{*}{ Upper } & \multirow{2}{*}{ Lance $\mathrm{Fm}$} & \multicolumn{2}{|l|}{ Hell Creek $\mathrm{Fm}$} \\
\hline & & & & \multicolumn{2}{|l|}{ Fox Hills Ss } \\
\hline & & & Lewis Sh & \multirow{2}{*}{\multicolumn{2}{|c|}{ Pierre Sh }} \\
\hline & & & Mesaverde $\mathrm{Fm}$ & & \\
\hline & & & Steele and Cody Shs & Niobrara Fm & \\
\hline & & & Frontier $\mathrm{Fm}$ & $\begin{array}{l}\text { Carlile Sh, Gree } \\
\text { and Belle Four }\end{array}$ & $\begin{array}{l}\text { horn Fm, } \\
\text { he Sh }\end{array}$ \\
\hline & & & Mowry $S_{1}$ & Mowry Sh &. \\
\hline $\begin{array}{l}-1 \\
\overrightarrow{0} \\
0 \\
0\end{array}$ & & Lower & Thermopolis Sh & $\begin{array}{l}\text { Newcastle } \mathrm{Ss} \text { and } \\
\text { Skull Creek Sh }\end{array}$ & \\
\hline$\stackrel{n}{\infty}$ & & & Cloverly Fm & $\begin{array}{l}\text { Fall River }{ }^{*} \text { and } \\
\text { Lakota Fms* }\end{array}$ & $\begin{array}{l}\text { Inyan } \\
\text { Kara* Gr. }\end{array}$ \\
\hline & & & Morrison Fm & Morrison Fm & \\
\hline & & & Sundance $\mathrm{Fm}_{\mathrm{m}}$ & Sundance Fm & \\
\hline & Jurassic & & Gypsum Spring Fm & Gypsum Spring Fm & \\
\hline & & & Nugget Ss & (Absent) & \\
\hline & Triassic & & $\begin{array}{l}\text { Jelm and } \\
\text { Chugwater } \\
\text { Fms }\end{array}$ & Spearfish Fm & \\
\hline & & & Dinwoody $\mathrm{Fm}$ & 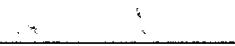 & \\
\hline & & & Goose Egg & Minne kahta Ls & \\
\hline & Permian & & $\begin{array}{l}\text { Phosphoria and } \\
\text { Park City Fms }\end{array}$ & Opeche Fm & \\
\hline & $\mathrm{D}-\mathrm{i}$ & & Tensleep Ss & Minnelusa Fm & \\
\hline & Pennsy $\perp$ van 1 & & Amsden $F_{m}$ & . & \\
\hline 答 & Mississippi & & Madison Ls & Pahasapa Ls : & $\because$ \\
\hline$\stackrel{\circ}{\mathscr{C}}$ & Devoni an & & $($ Absen $t)$ & Engl ewood $\mathrm{Fm}$ & 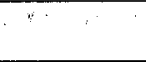 \\
\hline$\Xi$ & Otrian & & D. & Whitewood Ls & \\
\hline & Urdovician & & B1 ghorn Lol & Winnipeg Fm & \\
\hline & & & Gallatin Ls & Deadwood Fm & \\
\hline & Cambrian & & Gros Ventre Fm & & \\
\hline & & & Flathead Ss & (Absent) & \\
\hline Pre & cambrian & & Granitic and me & morphic rocks & \\
\hline & $\begin{array}{l}\text { * Pr } \\
\text { * } \text { Th } \\
\text { is } \\
\text { Di } \\
\text { Gas }\end{array}$ & $\begin{array}{l}\text { nicipal ur } \\
\text { mountainw } \\
\text { designated } \\
\text { ide Basin, } \\
\text { Hills Are }\end{array}$ & $\begin{array}{l}\text { anium-bearing unit } \\
\text { ard facies of the was } \\
\text { Battle spring Format } \\
\text { and Puddle springs F } \\
\text { a }\end{array}$ & $\begin{array}{l}\text { tch Formatio } \\
\text { on in the Gr } \\
\text { rmation in } t\end{array}$ & at \\
\hline
\end{tabular}

Figure 2. Principal stratigraphic units in the uranium districts of Wyoming and adjacent western South Dakota (modified from Harshman, 1968). 


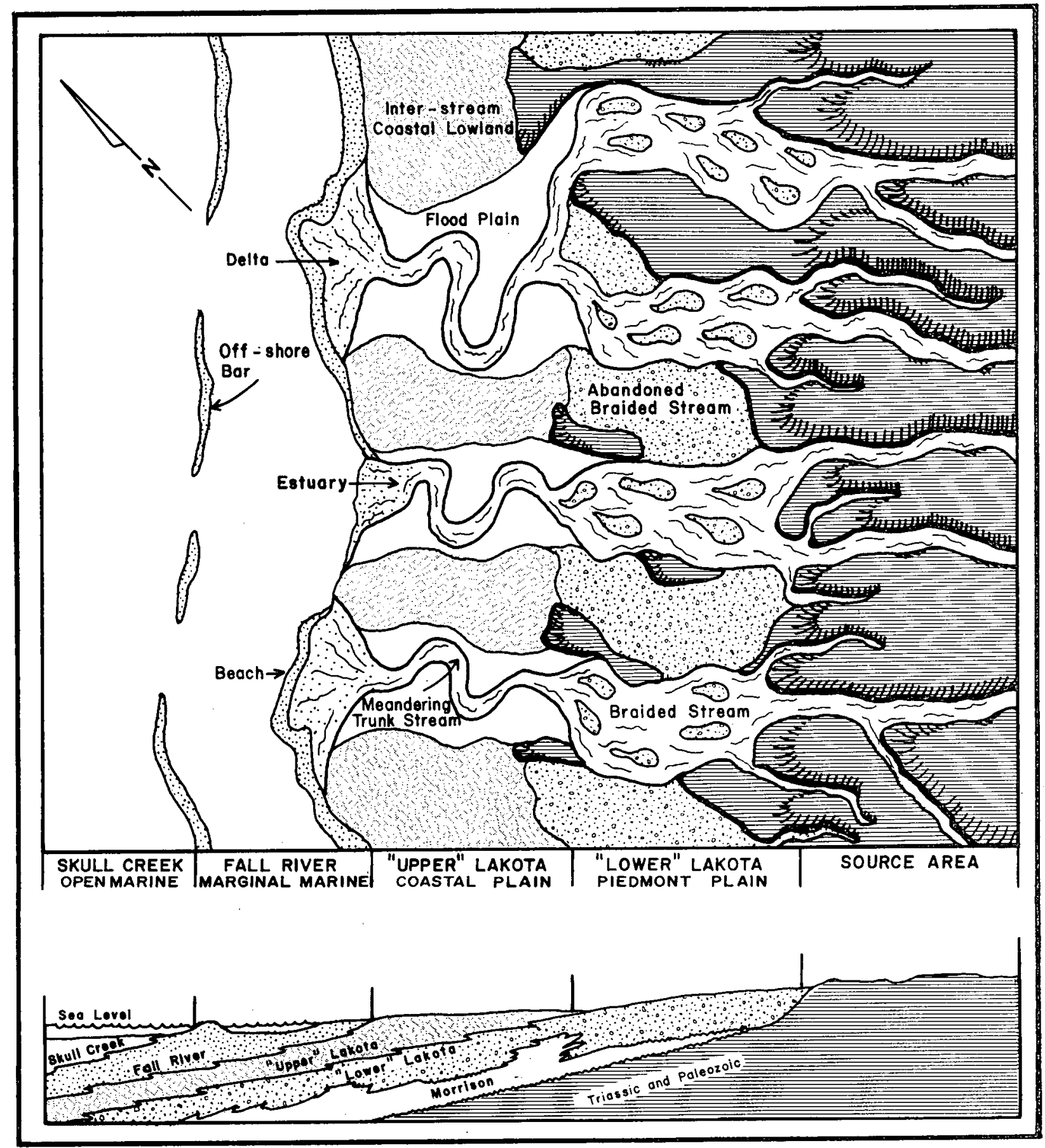

Figure 3. Diagramatic paleo-environment map and cross section of the Inyan Kara Group and related sediments, Black Hills region, South Dakota (modified from Renfro, 1969). 
The Fall River Formation overlies the Lakota with marked disconformity. It is 75 to 150 feet thick and consists predominantly of gray, buff, or brown, fineto medium-grained silicious sandstone interbedded with a few thin gray to black siltstones and claystones. The sandstones are thin bedded, tabular or tabular cross laminated. The sandstones commonly contain worm borings, ripple marks, and casts of marine organisms, features characteristic of shallow marine environments. The thin-bedded, laminated, character of the Fall River contrasts markedly with the massive character of the non-marine Lakota Formation. The uranium deposits occur in both the Lakota and Fall River Formations (Fig. 3).

Weld County, Colorado

Selected references: Weimer, 1973; Childers, 1974; Reade, 1976.

In Weld County, Colorado (Fig. 4), the host rocks for the roll-type uranium deposits are the Fox Hills and Laramie Formations of Late Cretaceous age (Fig: 2). The Fox Hills conformably overlies the marine Pierre Shale. It consists of several thick, moderately cemented sandstones separated by carbonaceous shale. The sandstones are generally medium- to fine-grained, gray to white, micaceous, and silicious. In some places thin lenticular beds of lignite are present in the section. The Fox Hills sediments were deposited in a littoral environment and represent the transition from marine to fluvial conditions of sedimentation. The Fox Hills is as much as 350 feet thick.

The Lance Formation conformably overlies the Fox Hills. It consists of shales, siltstones, and mudstones, occasional lignite beds and large channel sandstones deposited in fluvial, mudflat, and lacustrine environments. The sandstones are medium- to fine-grained, quartzose to feldspathic, micaceous, pyritic and contain considerable fine-grained carbonaceous material. They are light gray to white where unweathered. The sandstones are much cross-bedded, show slump features, and appear to have been deposited in major stream channels with moderate to low gradients. The Lance is as much as 1600 feet thick.

The White River Formation of 01igocene age (Fig. 2) unconformably overlies much of the late Cretaceous rocks in the Weld County area. The White River comprises a sequence of arkosic, coarse-grained to pebbley sandstones, deposited in channels that in some places cut into the underlying Cretaceous rocks, overlain by siltstones and mudstones. All of the Oligocene rocks contain considerable tuffaceous material, the source of which was probably in northwestern Wyoming. Except for the basal part of the White River Formation, the rocks are of low permeability. The Arikaree Formation of Early Miocene age disconformably overlies, or at one time overlay, the white River Formation. It consists of fluvial deposits of sand, gravel, and clay, containing considerable tuffaceous material, derived from the mountains that lay to the west. 


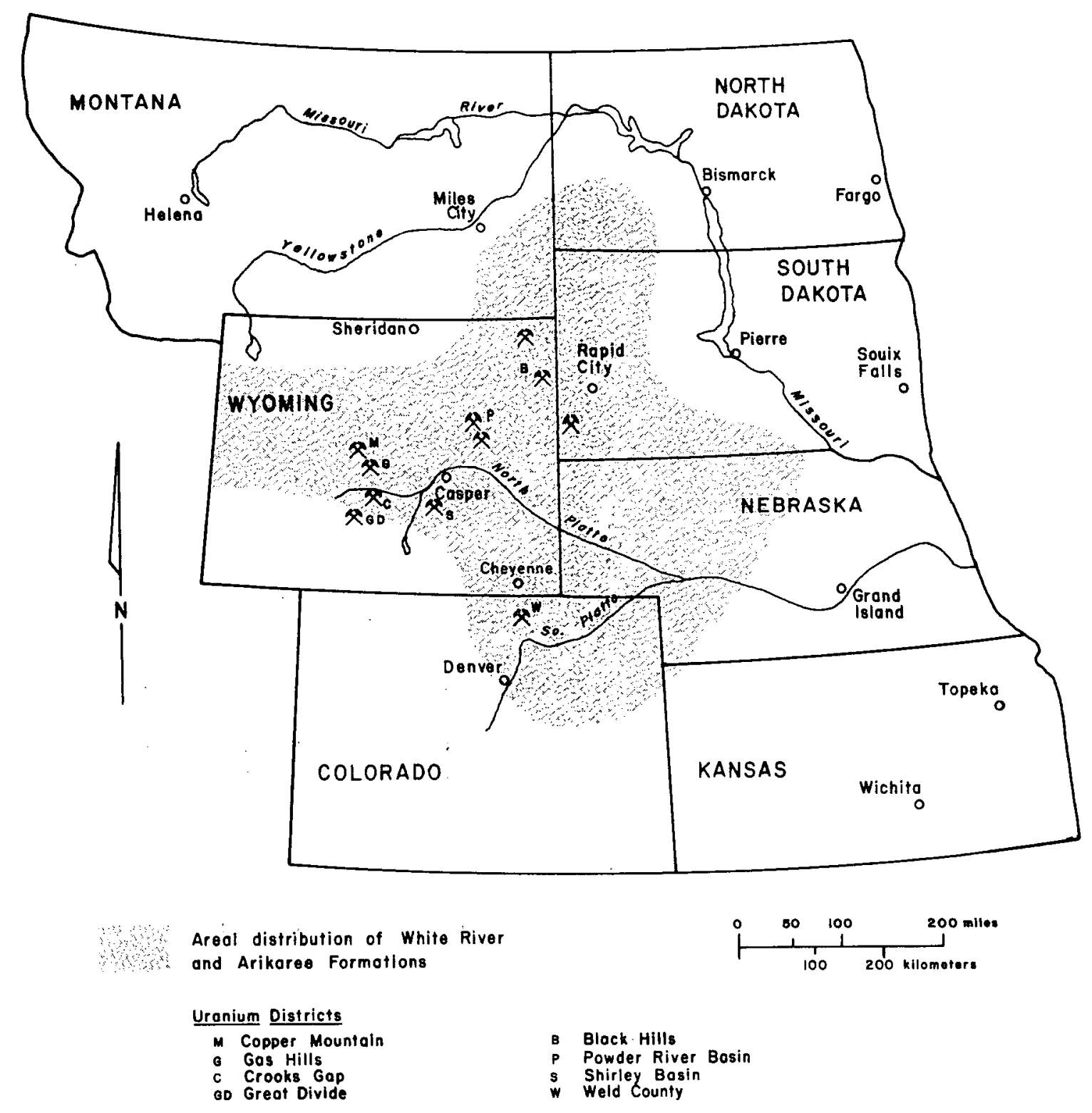

Figure 4. Generalized map showing areal distribution of White River and Arikaree Formations, interpreted from present outcrop distribution, and principal uranium districts (modified from Denson et a1, 1959). 
Wyoming Basins

Selected references: Masursky, 1962; Sharp and others, 1964; Sharp and Gibbons, 1964; Stephens, 1964; Van Houten, 1964; Soister, 1968; Houston, 1969; Keefer, 1970; Love, 1970; Pipiringos and Denson, 1970; Denson and Chisholm, 1971; Childers, 1974; Harshman, 1972; Dah1 and Hagmaier, 1976.

The largest and highest grade roll-type uranium deposits are found in Tertiary rocks filling the Wyoming basins. The fill ranges in age from Paleocene to Quarternary, but only the Paleocene and Lower Eocene sandstones contain significant deposits.

The Paleocene Fort Union Formation is present in all the Wyoming basins, but in the Shirley Basin it was largely removed by erosion prior to deposition of younger rocks. According to Denson and Chisholm (1971), it consists of very fine-grained sandstone and quartzite with admixed silt, clay, and coal, all of fluvial or lacustrine origin. Although the Fort Union is predominantly a fine-grained, impervious formation, it contains coarse stream debris, particularly near the mountain fronts that flank the basins. The coarse debris is composed largely of quartzite, limestone, chert, and sandstone pebbles derived from the Paleozoic and Mesozoic rocks exposed in the uplifts. Arkosic material is rare. The thickness of the formation ranges from less than 100 feet in the Shirley Basin to as much as 3000 feet in the Powder River Basin. The Fort Union rests on an erosion surface of several hundred feet relief cut in folded and faulted Paleozoic and Mesozoic rocks that floor the basins, and it is overlain unconformably by rocks of Early Eocene age.

The Wasatch, Wind River, and Battle Spring Formations (Fig. 2) of Early Eocene age are host to the principal uranium deposits in Wyoming. The three formations are approximate time equivalents, and have many lithologic, textural, and compositional similarities. They comprise a sequence of arkosic sandstones, conglomerates, siltstones, claystones, carbonaceous shales, and coal, of fluvial and lacustrine origin. In contrast, with the underlying Paleocene rocks, the Wasatch and stratigraphic equivalents contain much granitic debris indicating that erosion had stripped the sediments from and exposed the granitic cores of the uplifts that border the basins.

On a regional basis, Lower Eocene rocks can be divided into two distinctive lithologic units--a mountainward facies comprising coarse clastic rocks with boulders as much as 25 feet in diameter, and a basinward facies comprising fine-grained clastic sediments with some interbedded pebble, cobble, and boulder beds. The two facies interfinger and intertongue, the areal extent of either facies being determined by the vigor of the streams transporting the clastic debris toward the center of the basins. Interfingering of the Wasatch (basinward facies) and Battle Spring (mountainward facies) Formations is shown on Figure 21. Correlation of gross 1ithologic units can be made over many miles, but individual coarse-grained beds have limited continuity. Sandstone units range from a few to 200 feet in thickness. They are separated by siltstones and claystones of similar thickness. Wasatch and equivalent rocks are not present, in the Black Hills or. Weld County uranium districts but are present in the Gas Hills; : Shirley: Basin, Powder River Basin, and Crooks Gap-Great Divide Basin. The total thickness of the Wasatch and equivalent rocks ranges 
from about 500 feet in the Shirley Basin to more than 3000 feet in the Crooks Gap-Great Divide Basin area. A more detailed description of the ore-bearing sandstones in the Wasatch, Wind River, and Battle Spring Formations will be found in a subsequent section of this report.

Rocks of the Upper Eocene Wagon Bed Formation are present in the Gas Hills and Shirley Basin areas of Wyoming; and they were probably present at one time in the Crooks Gap-Great Divide Basin area. They overlie the Lower Eocene with apparent conformity. The Wagon Bed comprises a series of silicious bentonites, siltstones, mudstones, sandstones, and yellowish or greenish-gray tuffs. In some areas the tuffs have been altered to clinoptilolite; in other areas they are relatively unaltered. The lower portion of the Wagon Bed contains considerable poorly-sorted arkosic sandstone similar to that in the underlying formation, and there appears to be no depositional break between the two. The formation is largely of fluvial origin and contains appreciable amounts of volcanic ash. According to Denson and Chisholm (1971), this is the most impervious formation in the Tertiary sequence. In some areas the Wagon Bed Formation had been completely removed by erosion at the end of Eocene or the beginning of 0ligocene time, but where present, it may be as much as 300 feet thick.

Unconformably overlying the Wagon Bed, or the Wasatch, Wind River or Battle Spring where the Wagon Bed has been eroded, is the White River Formation of 0ligocene age. It is comprised of tuffaceous siltstones, claystones, sandstones, and conglomerates, as well as some fresh water limestone and relatively pure tuff beds. The clastic rocks are pastel shades of pink, gray, green, and tan; the tuffs and limestones are white.

In the Gas Hills and Shirley Basin areas, the White River Formation can be divided, on the basis of lithology, into two units of about equal thickness. The lower unit contains predominantly fine-grained rocks with lenticular sandstones and conglomerates near the base in some areas; in other areas varigated claystones and/or white tuff beds are present at or near the base of the unit. The upper unit consists of fine-grained rocks, similar to those in the lower unit, interbedded with coarse-grained, lenticular sandstones and conglomerates. The coarse-grained rocks appear to be fanglomerates deposited by streams originating in the mountains that flank the basins. These coarse clastics are good aquifers and give rise to many springs.

The White River Formation at one time probably covered most of central and eastern Wyoming, northeastern Colorado, and the western parts of South Dakota and Nebraska (Fig. 4). It has been eroded in recent times from the Black Hills area, from the Powder River Basin (except for a few small remnants in Pumpkin Buttes) and from the Crooks Gap-Great Divide Basin area. Where present in its entirety, the White River averages about 850 feet thick.

The Arikaree Formation of Early Miocene age and the Ogallala Formation of Late Miocene and Pliocene age overlie the White River in parts of Wyoming and Colorado. The Arikaree is present in the Weld County, Shirley Basin, and Gas Hills districts, where it is composed of white, buff, or tan, fine- to mediumgrained, poorly bedded sandstone. A chalky white conglomerate is locally present near the base. According to Denson and Chisholm (1971) "good:sorting, laterally persistent lithology, and the general absence of coarse detritus and 
of locally derived debris are outstanding characteristics." The formation is in part fluvial, in part aeolian, and consistently tuffaceous. Its eroded thickness rarely exceeds 200 feet.

The Ogallala Formation has been removed by recent erosion from most of the uranium-bearing districts. Where present, it is separated from the underlying Arikaree by a major unconformity. Its 1ithology ranges greatly from area to area, but for the most part it is composed of fluvial siltstones, claystones, sandstones, and conglomerates that may contain considerable fluvio-volcanic material and opal cement.

\section{Summary}

The sedimentary sequences which host the uranium deposits of the Black Hills and Weld County districts are marginal marine sequences deposited respectively in a marine transgression and a marine regression. They are in marked contrast to the Tertiary basin fills of continental clastic sediments found in the Wyoming basins. The basin fill sediments reflect the high relief and rapid erosion caused by block faulting and mountain uplift which was followed, not surprisingly by explosive acid vulcanism as evidenced by the high tuffaceous content of the Wagon Bed, White River, and Arikaree Formations. 
FAVORABLE HOST SANDSTONES

Selected references: Harshman, 1968; Childers, 1974; Rackley, 1976; Ga1loway, 1979; McGowen, 1979.

Most host rocks for roll-type uranium deposits are similar in their physical, mineralogical, and geochemical character, as well as in their position of deposition in the fluvial sedimentary cycle. A knowledge of these characteristics and the sedimentary processes that produced them is of utmost importance in ore-potential estimates of large areas and in selection of smaller areas for exploration. A brief discussion of the sedimentary depositional system taken largely from Galloway (1979) and McGowen (1979), will serve as background for discussions of the host rocks in the Wyoming basins and Black Hills.

Depositional systems are efficient sorters of clastic material and different environments within the system are generally characterized by specific geologic characteristics which make some environments subsequently favorable and some unfavorable as hosts for uranium deposition. In general there is a progressive decrease in the clast size from the upper or mountainward part toward the distal or basinward part, a change that relates directly to host rock favorability.

Figure 5 is a hypothetical plan and section of a complete depositional system, showing the gradient, character of flow, physiographic regions traversed, character of the stream sediment load, and depth of the water table. In traversing from the proximal fan to the delta, the trunk channel changes from bed-load to mixed-load, and suspended load in response to changes in gradient, sediment and discharge. Most of the host rocks in the Wyoming basins and in the Black Hills fall in the upper (right) half of the figure, that is, in the bed load-mixed load part of the depositional system. At the mountainward end of the clastic depositional system is the alluvial fan ${ }^{1}$ which may be either wet or dry depending on the nature of the climate during deposition. The fans in the Wyoming basins were deposited under tropical or semitropical conditions and are of the wet type. Alluvial fans are characterized by the great size range of their detritus from boulders several feet in diameter to fine-grained silt and clay. They are deposited near the sediment source, under high energy intermittent stream flow, and in areas where streams pass from mountain fronts into adjacent basins. In cross section they are wedge-shaped piles of debris, thicker and coarser-grained near the mountain front, and thinner and finergrained at their basinward extremity. Those in the Wyoming basins range in length from a few miles or tens of miles, as in the Gas Hills and Shirley Basin, to as much as 30 to 35 miles in the Great Divide Basin.

\footnotetext{
IIn this report the term "fan" is restricted to those cone-shaped piles of debris deposited where streams issue from mountain fronts onto adjacent lowlands (McGowan, 1979). Galloway (1979) uses the term more broadly in discussing the Westwater Canyon member of the Morrison Formation in the Grants Mineral Belt, New Mexico. In that district he refers to the entire Westwater depositional system as a "wet alluvial fan" which may correspond to alluvial apron in some readers' terminology.
} 


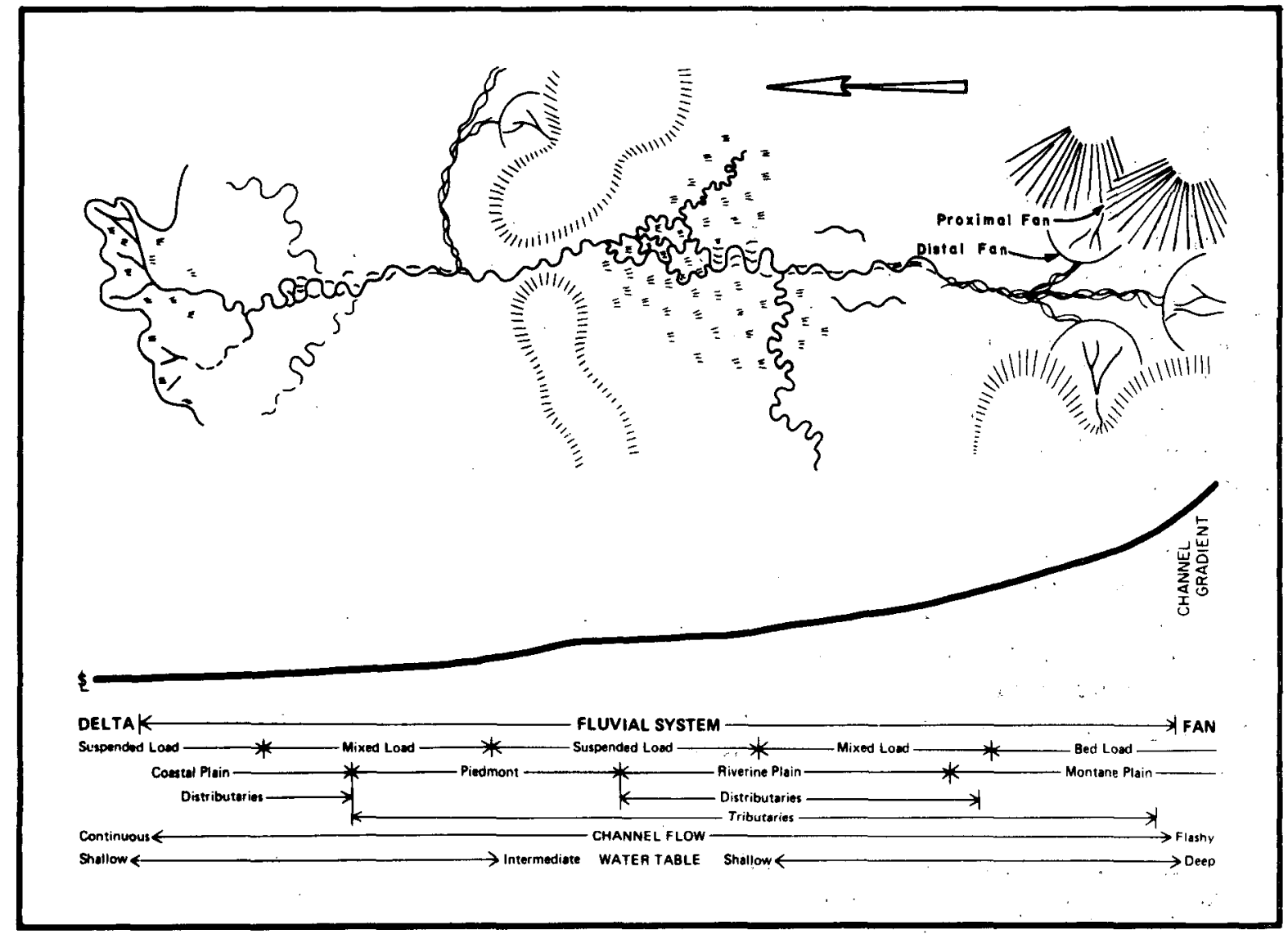

Figure 5. Hypothetical fluvial system traversing a montane basin and associated riverine plain and debouching across a piedmont into a prograding deltaic coastal plain. (modified from Galloway, 1979).

A single straight channel generally occupies the upper (or proximal) part of a wet fan, but a short distance down the slope the single channel gives way to: a braided stream with many small channels. In the distal part of the fan, where the clast size decreases and the stream gradient becomes lower; the braided stream system gives way to a single channel system.

Permeabilities are very high in the coarse debris of the proximal (upper) part of the fan, water tables are low and organic material generally is sparse. Boulders and gravel are the dominant clasts. In the midfan area permeabilities decrease somewhat but remain high. Organic material remains sparse, and water tables are low. Gravel and sand are the dominant materials. Toward the toe (distal part) of the fan, grain size and permeabilities decrease, the amount of organic material increases, and the water table rises. Sand is the predominant detritus, but some silt and clay may accumulate interbedded with it. This distal part of the alluvial fan system is a favorable host rock for rol1-type uranium deposits. 
Downstream the distal part of the fan merges with the upper, more vigorous, part of the fluvial system, a system that serves mainly to collect and transport material toward the sea. However, large volumes of clastic material may accumulate in intermontane basins, large interior lakes, and stable coastal plains.

Fluvial systems consist of a mixture of channel fill, channel margin, and flood-basin deposits. Channel fill deposits form the framework of a fluvial system and include both aggradational and lateral-accretion depositional units. Channel margin deposits occur during flood stage when sediment is deposited along channel margins as water overflows the confining stream banks. The velocity of the unconfined water decreases rapidly and the coarser entrained sediment may reach the broad interchannel areas to form the interchannel flood-basin deposits. Sedimentation in the flood-basin is slow and reworking by burrowing and plant growth destroys the primary sedimentary textures. In moist climates, organic productivity is high and lignitic deposits may form.

Channels have been classified according to the ratio of the bed load to the suspended load which the stream transports, and one such classification is summarized in Figure 6. Bed-load and suspended-load channels are the end members of channel types which evolve from the upper or proximal to the distal

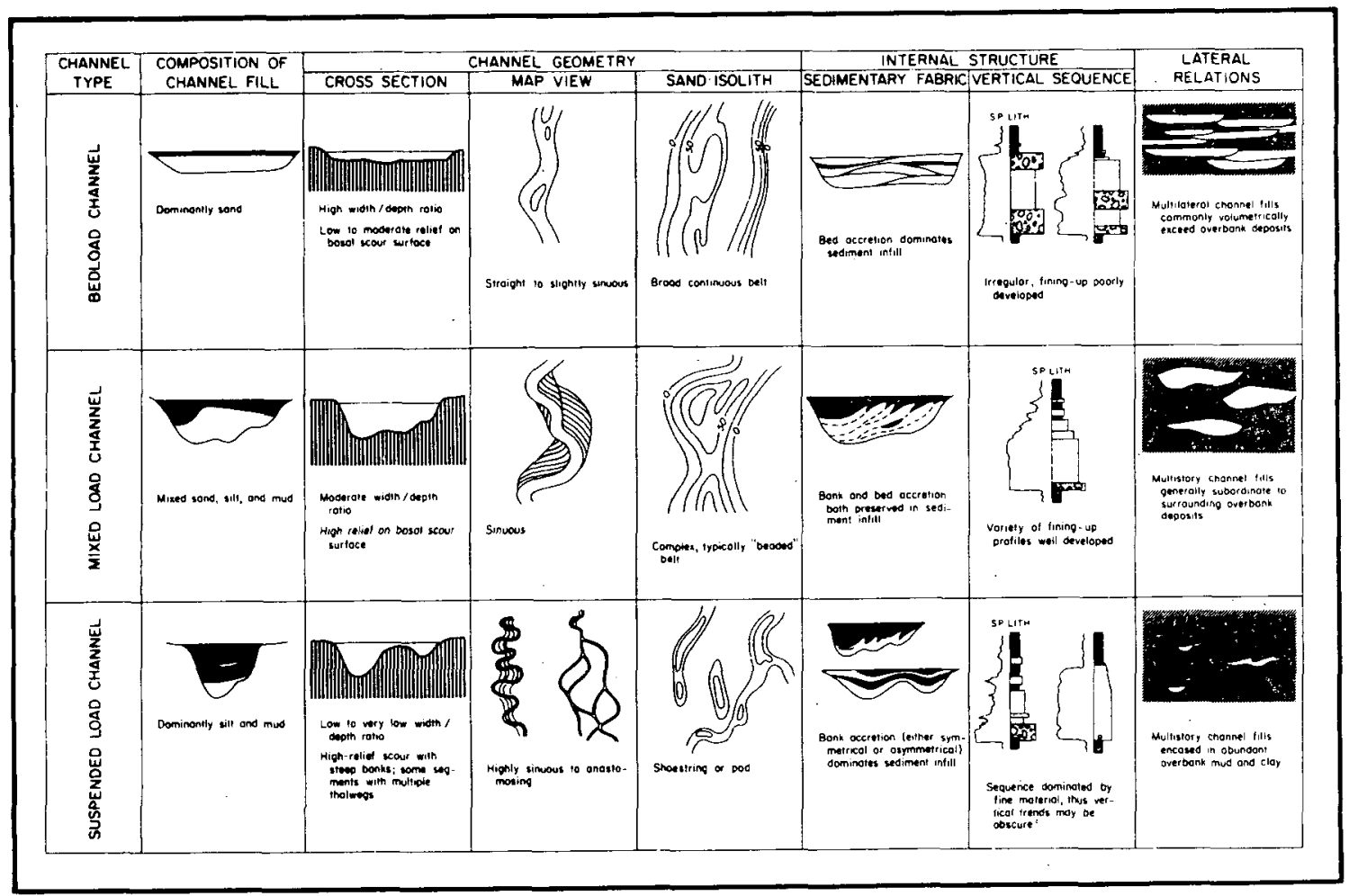

Figure 6. Geomorphic and sedimentary characteristics of bed-load, mixedload, and suspended-load channel segments (from Galloway, 1979). 
or downstream part of the fluvial system. Bed-load channels are characterized by relatively steep gradients, straight to slightly sinuous channels, lateral erosion and deposition, coarse-grained channel fill, and high width/depth ratios. In contrast, suspended-load channels are characterized by relatively low gradients, sinuous channels, vertical erosion and deposition, fine-grained channel fill containing abundant suspended-load sediment, and low width/depth ratios. Mixed-load channels occupy a middle position.

Bed-load channel fills consist principally of fine- to medium-grained sand, although coarse sand and gravel may be significant components. Interconnecting multilateral sand bodies are a common feature. Water tables in the interchannel areas are generally deep because these systems occur in the upper reaches of basins and the flood plain and channel sediments are permeable. Some carbonaceous material occurs in both sandy and silty material. The coarse-grained units of bed-load channel fills are favorable hosts for uranium deposits.

Mixed-load channel fills contain considerable sand along the channel axes, but this material may be subordinate to the overbank deposits. Channel fill units are vertically stacked. Water table depths are governed by water level in the channel and much of the channel fill and low lying backswamps remain saturated; organic material is common and is preserved by high water tables. Uranium deposits occur in the coarse-grained units of mixed-load channel fills.

Suspended-load channel fills are characterized by low sand percentages, and considerable organic debris protected by high water tables. Sand units are lenticular in cross section, and tend to be stacked and encased in finegrained sediment. Flood basin deposits consist of swamp and lacustrine muds and clays. Suspended-load channel fills are generally unfavorable for rolltype uranium deposits, but may contain uranium associated with the lignitic material common in this class of fluvial sediments.

The most favorable host rocks for known roll-type deposits, or perhaps more accurately the hosts containing the largest and/or highest grade deposits, are the Early Eocene sandstones of the Wyoming basins. They are friable, fine- to coarse-grained or pebbley, arkosic, and contain considerable pyrite, carbonaceous material, and occasional iron-stained mudstone clasts. The sandstones range from a few to a few hundred feet in thickness, and they contain tabular mudstone splits. Crossbeds are universally present, as are sand- or siltfilled channels. Individual sandstone beds within units that are predominantly sandstone have limited lateral continuity, but the sandstone units may extend for as much as 20 or 30 miles (Davis, 1969; Sherborne and others, 1980). These sediments were deposited under coarse bed-load conditions or on the distal parts of wet alluvial fans (Galloway, 1979).

Carbonaceous material is dispersed through the host sandstones with somewhat greater concentration on cross stratification beds. This organic debris is generally fragments of leaves and twigs, although Childers (1974) reports humic material coating sand grains in some of the Wyoming deposits. A few large sections of tree trunks and branches, some silicified and others carbonized, are present in the Shirley Basin host rocks. The organic carbon content of the host rocks ranges widely from place to place but probably averages 0.5 percent or less. 
Pyrite is present in all of the uranium host rocks. It is generally disseminated through the sandstone, but also may be present in large amounts locally as a cement in coarse-grained sandstone or replacing carbonaceous material. Pyrite content of sandstone in an ore-bearing unit (but unaffected by oreforming processes) ranges from about 1 to 3 percent. The pyrite is thought to be diagenetic and to have been formed by the reaction of biogenic hydrogen sulfide with iron-bearing minerals in the sandstone. The habit and character of pyrite related to the ore-forming process will be discussed later in this report.

There is little siliceous or calcite cement in the Eocene host rocks although these friable sediments have been compacted by the weight of several thousand feet of clastic material that overlies or once overlaid them. Calcite concretions are sparingly present in the host sandstones but are not characteristic of them. Calcite contents (based on acid soluble and mineral carbon determinations) of favorable sandstones unaffected by the mineralization processes are generally less than 1 percent. Calcite related to ore deposition will be discussed later in this report.

Detrital heavy minerals constitute 2 to 5 percent of the sandstone in the Shirley Basin (Harshman, 1972); included are most of the minerals characteristic of clastic sediments derived from plutonic and metamorphic rocks. Denson and Chisholm (1971) show an average content of about 1 percent heavy minerals in the Lower Eocene rocks of Wyoming and adjacent states, and Bailey (1969) shows somewhat less than 1 percent of heavies in the Crooks Gap sandstones.

Below the water table, and where not altered by the ore-bearing solutions, the host sandstones have not experienced oxidation either at the time of their deposition or subsequently. They are generally light gray or greenish gray, the color being dependent on the amount of pyrite, the amount of organic material, and the mineralogical composition of the sediment. The fine-grained rocks interbedded with the sandstones are greenish gray, dark gray, brown to tan, and almost black when high in organic material. They range from firm claystones to compact but somewhat friable siltstones; much of the material can be classed as mudstone.

Sandstones of the type just described have a limited distribution in the total volume of material deposited in the Wyoming basins. A brief discussion of the early history of sedimentation will help position the favorable host rocks geographically within the basins and relate the depositional environments to the fluvial system discussed in earlier paragraphs.

Sedimentation began shortly after Laramide faulting and uplift outlined the Wyoming basins and mountain ranges as we know them today. As erosion stripped the sedimentary rocks from the flanks of the uplifts, fine-grained second cycle material was deposited in the basins. In some places the granitic cores were exposed in Paleocene time and coarse arkosic sediment was deposited near the mountain fronts. Uplift, and probably down warping continued into Lower Eocene, and well-defined braided streams carried arkosic debris from the mountains into the basins. By present-day standards, these streams were large, as was their bed load. Huge fans, some more than 30 miles long, deve1oped on the flanks of the basins. Coarse boulders were deposited toward the 
centers of the basins. In periods of high flow the streams left their banks and deposited fine-grained clastic debris in inter-stream areas and on flood plains while at the same time coarse-grained material was deposited in the stream channels. There was considerable lateral shifting of the streams and some channeling of previously deposited sediment. These are the sediments of the Wind River and Wasatch Formations which host the ore deposits. Although the lowest parts of some of the basins were occupied by shallow lakes and coal swamps, all of the ore-bearing Wyoming basins had exterior drainage.

Fossil evidence indicates that the humid warm climate that began in the Cretaceous continued through the Early Tertiary, probably becoming temperate by Middle 0ligocene. The tropical climate supported growth of lush vegetation in uplands and along streams. It also caused deep weathering of the granitic rocks in the uplifts, rapid transfer of the eroded arkose down the basin slopes, and massive deposition of material in the basins. Dry periods may have alternated with wet periods, but most of the arkose remained saturated and reduced chemically, a critical factor in subsequent ore deposition. Figure 7 (Galloway, 1979) shows the two major Paleocene-Early Eocene drainage systems in Wyoming, as well as other geologic features related to the principal uranium mining areas.

As the uplands were eroded and the basins were filled, the vigor of the streams decreased and the arkoses deposited in Early Eocene were buried by finegrained clastic sediments admixed with volcanic debris from vents that became active in western and central Wyoming in Middle. Eocene time and remained active through the Pliocene (Houston, 1969). This burial by the White River and younger formations subsequently served to protect the Early Eocene arkosic rocks and their uranium deposits from Pleistocene and Recent erosion and oxidation.

The 1ithologies favorable for ore deposition are found principally in the central part of the fluvial system briefly described above. The very coarse debris deposited high on a basin margin is probably subject to intensive oxidation during dry periods when stream flow is low and ground water tables fa11. The reducing environment so necessary to the ore-forming process is thus destroyed soon after the deposition of any organic debris, if in fact reducing conditions ever existed. Additionally, the rate of ground water flow through this material is probably much greater than that believed to be optimum for forming the oxidation-reduction interface necessary for ore deposition. This environment would correspond to the proximal parts of the fan.

The flood plain and lake bed deposits in the lower part of a basin remain reducing long after deposition but they are so very fine-grained and impermeable that movement of water through them is greatly inhibited. This environment would correspond to the riverine plain in Figure 5. Between these two extremes is a region where stream gradients are moderate and permeable carbonaceous channel sands with considerable longitudinal continuity, interbedded with fine-grained sediments, are deposited in shallow but wide stream channels. These are the sediments that contain most of the uranium deposits of the Wyoming basins.

The uranium deposits in the Black Hills and Weld County, Colorado, areas are found in rocks deposited under hydrologic conditions somewhat different than 


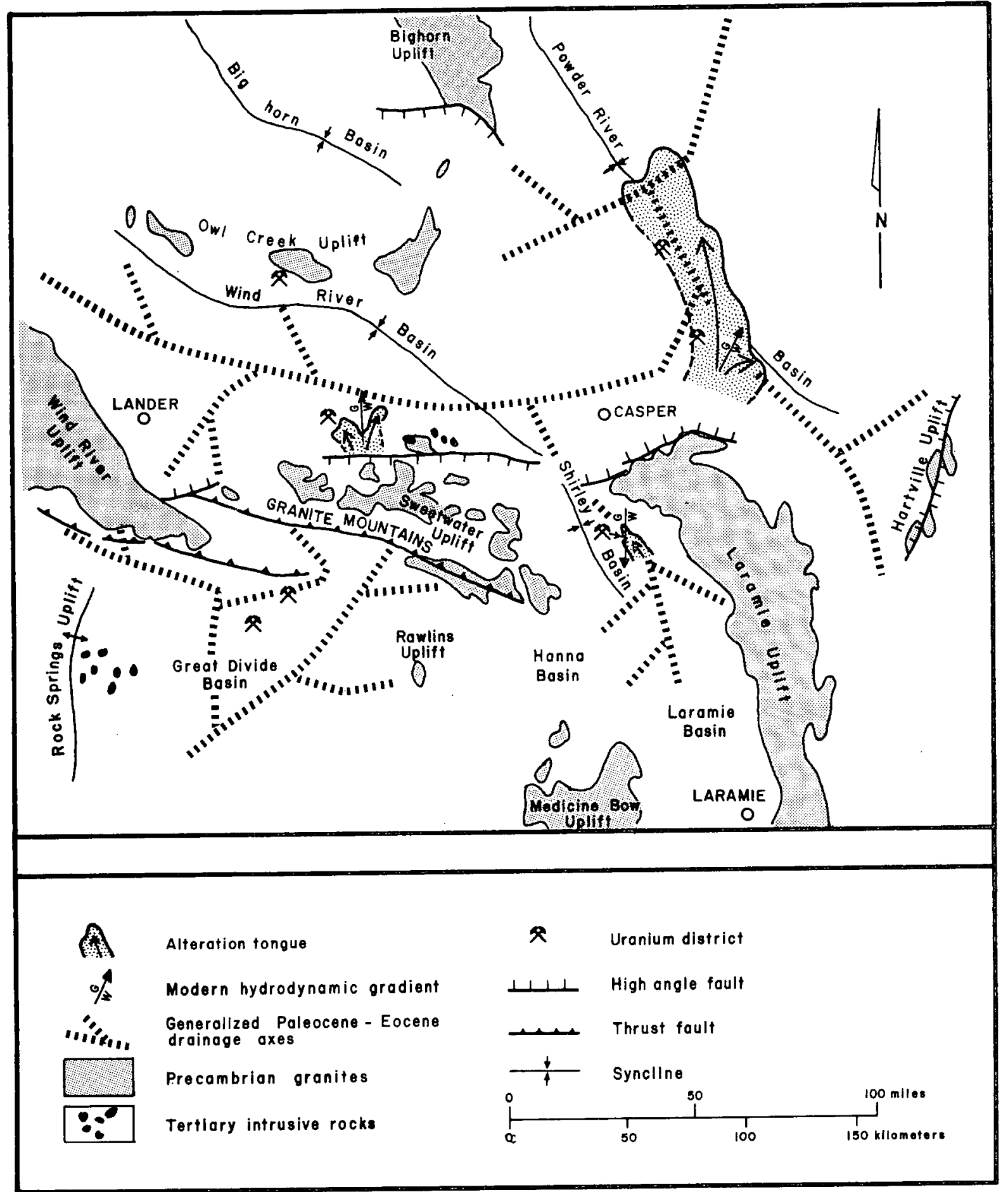

Figure 7. Regional setting of the principal uranium districts, alteration tongues and present and inferred Paleocene/Eocene drainage systems, Wyoming intermontane basins (modified from Galloway, 1979). 
those in the Wyoming basins. In the Black Hills the hosts are part of a sequence of Lower Cretaceous (Inyan Kara) sedimentary rocks deposited by streams of moderate gradient flowing northwesterly somewhat parallel to the axis of the present Black Hills uplift. The sediment is highly siliceous and according to Cuppels (1963) it was deposited in a "stable shelf environment of a continental platform." The shelf lay to the east of the inland sea that invaded the area at the close of Inyan Kara time. The lower part, or Lakota Formation, consists of many intertonguing lenses of cross-stratified, fine- to coarse-grained fluvial sandstones, fine-grained flood plain deposits, lake beds, and occasional beds of lignite. Many of the sandstones are in large interconnected lenses, but some lenses are small and isolated. The streams moved latera11y within their rather broad channels and changes in the vigor of the streams caused considerable cutting and filling. This depositional environment would correspond to coastal plain-piedmont environment of Figure 5 .

The upper part of the Inyan Kara Group, or Fall River Formation, is transitional between the fluvial sediments of the Lakota Formation and the marine shales of the overlying Skull Creek Shale. According to Ryan (1964) the Fall River rocks are of continental origin, but they were deposited under lagoonal or coastal swamp conditions in the "terrestrial phase of a deltaic environment." This concept agrees with that expressed by Renfro (1969) who identifies the "Lower" Lakota as fluvial piedmont-plain, the "Upper" Lakota as fluvial coastal-plain, and the Fall River as marginal marine. The Fall River sandstones, like those of the Lakota, are highly silicious and carbonaceous. The analogy in Figure 5 would be the coastal plain-delta depositional environment.

In contrast to the host rocks in the Wyoming basins, those in the Black Hills are in smaller sandstone units, are of lower permeability, are less arkosic, and over large areas are probably much less transmissive. These factors limit the size and grade of the uranium deposits in the Black Hills.

The Weld County deposits are in Late Cretaceous fluvial and marginal marine sandstones of the Fox Hills and Laramie Formations. The host rocks are generally quartzose to feldspathic, medium- to fine-grained sandstones containing considerable carbonaceous material. Sandstone thicknesses range from a few to as much as 100 feet. The environment of deposition, paleoclimate, and general character of the host sandstones are more comparable to the Black Hills than to the Wyoming basins. 
In discussions that follow, a number of terms will be used to describe the various physical and chemical components of roll-type uranium deposits. The terms used in this report are those used by Harshman (1972) during the 1 ast 18 years in describing rol1-type uranium deposits of Wyoming, South Dakota, and Texas. They have been generally, but certainly not universa11y, accepted by other authors and for this reason a correlation of the most commonly used terms is presented to assist investigators in applying the principles discussed in this report to descriptions of deposits prepared by authors using other nomenclature. Figure 8 shows the principal features of roll-type uranium deposits and a correlation of the more common terms used to describe them.

Rol1-type uranium deposits are everywhere genetically and spatially related to tabular masses or tongues of altered sandstone. The altered tongues range considerably in size and shape; they may be as much as one hundred or more square miles in area and several tens of feet thick. In most districts there are several altered tongues within a generally favorable sequence of beds, each separated from the other by an interval of fine-grained impervious sediment. In some instances superimposed tongues of altered sandstone are connected by altered sand filling a depositional breach in the bounding impermeable sediments. Although altered tongues frequently overlap, their edges are rarely superimposed. Tongues of altered sandstone may or may not completely fill the sandy interval in which they are confined. Incompletely filled intervals occur most frequently at the ends of the altered tongues.

The character of the alteration differs from district to district, but the overall effect of alteration is one of oxidation. Similarities between altered sandstone in the major districts include: (1) a distinctive change in color from the normal gray of unaltered sand; (2) a selenium content considerably higher than in unaltered sand; (3) a eU/U ratio generally higher than in unaltered sand; (4) calcium carbonate, organic carbon and sulfate contents much lower than in unaltered sand; and (5) partial or complete destruction of some or most of the heavy minerals, particularly pyrite and magnetite. Figure 9 is a simplified cross section of the principal types of alteration in some of the uraniûm mining districts discussed later in this report.

The largest orebodies occur at the margins of the tongues of altered sandstone and extend outward for distances of a few to as much as 300 feet. They are. somewhat crescentic in cross section, but simple crescent-shaped orebodies are rare. Ore is not continuous along the edges of the altered tongues, but it may extend laterally for several thousand feet. Small orebodies are found on the top and bottom surfaces of the altered tongues and associated with small bodies of residual unaltered sandstone enveloped by the tongues.

Typically, ore in a roll-type uranium deposit is in sharp contact with the host sandstone on the concave side or trailing edge, but on the convex side or leading edge the uranium content of the ore gradually decreases until it merges with unmineralized sandstone. 


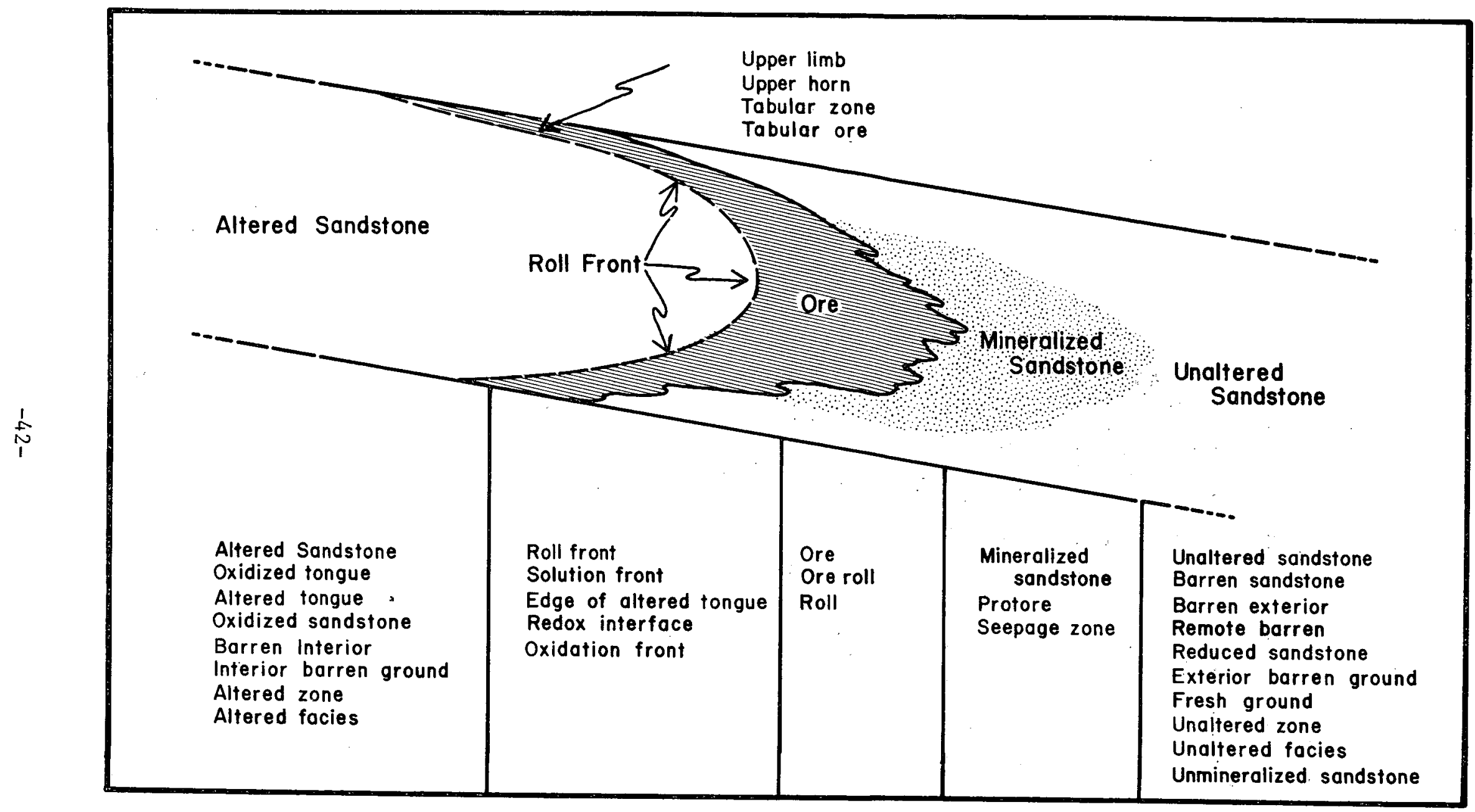

Figure 8. Correlation of terms used to describe various features of roll-type uranium deposits. 


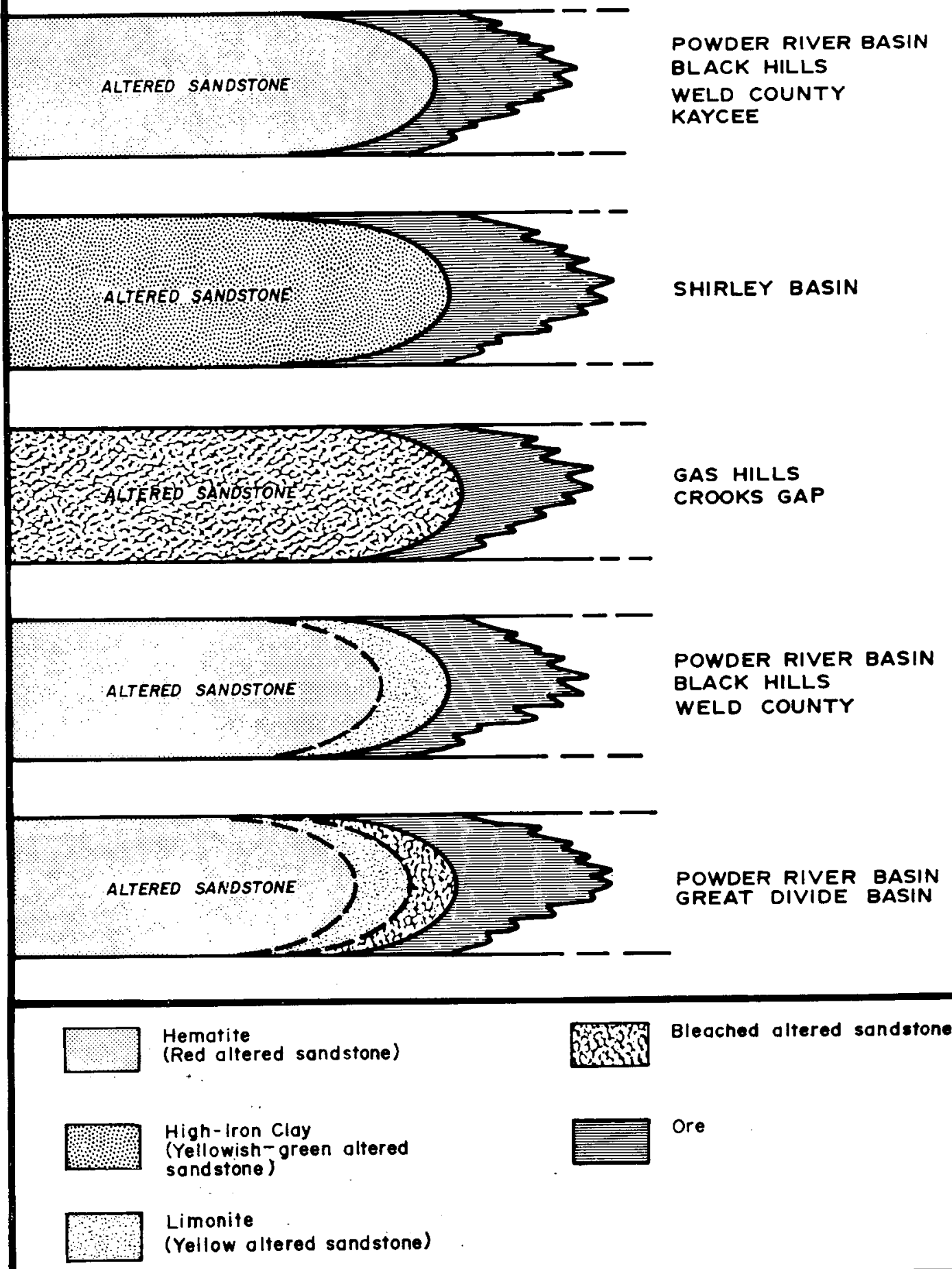

Figure 9. Simplified cross sections across the edges of altered sandstone tongues showing the most common types of alteration present in some uranium mining districts. 
Primary ore minerals are uraninite and coffinite emplaced as coatings on sand grains, as a cementing material filling the voids in the sandstone, and possibly replacing organic detritus. The uranium content of mineralized sandstone may be as high as 60 percent in small specimens, but is generally less than 1 percent. Since the term ore applies more to economics than to geology, it is impossible to determine an average grade for ore in roll-type deposits. The average grade of ore as mined in most deposits ranges from 0.05 to 0.25 percent $\mathrm{U}_{3} \mathrm{O}_{8}$.

Sedimentary structures appear to have exercised some control on ore deposition, but in many cases ore indiscriminantly cuts across such structures. It may be generalized that gross sedimentary features controlled the position of the orebodies, and that to some extent minor sedimentary features influenced their form.

Several elements, in addition to uranium, have been deposited in the minera1ized area adjacent to the altered tongue. Genetic theories proposed to explain solution, transportation, and deposition of uranium must also account for the presence of these elements and the sequence of their deposition.

The following summary of the sedimentary environment, habit, and mineralogy of the deposits in the most important roll-type uranium mining districts is presented in order to show the many similarities, as well as the differences, exhibited by the deposits. These data will be used to hold speculation on the genesis of roll-type uranium deposits within the bounds of reason.

Shirley Basin Area

Selected references: Melin, 1964, 1969; Bailey, 1965; Harshman, 1968, 1972; Rackley, 1972 .

The Shirley Basin is a structural and poorly defined topographic basin lying between the Laramie Mountains on the east and the southern part of the Sweetwater Mountains (Shirley Mountains) on the west (Fig. 7). Ore is associated with two well-defined tongues of altered sandstone. The basin contained reserves of over $125,000,000$ pounds of $\mathrm{U}_{3} \mathrm{O}_{8}$ that have been and are being exploited in one underground mine and several open pits.

The Wind River Formation of Early Eocene age is the host rock for the Shirley Basin deposits. It is an arkose derived principally from the Sweetwater Mountains to the west and deposited within the reaches of a braided fan and channel fluvial system flowing northerly through a basin, open to the north, eroded in Cretaceous and older rocks (Fig. 7). Sediments in the western part of the basin were deposited on a broad alluvial fan, those in the central part in the main channel and adjacent overbank areas of the trunk stream, and those in the east part in tributary channels and flood plains of streams originating in the Laramie Mountains on the east flank of the basin (Harshman, 1972).

The major deposits are in a well-defined belt of favorable sandstone that lies west of a 100 to 400 foot high ridge on the Pre-Wind River erosion surface. 
The ridge, now buried, is believed to have controlled the position of the favorable belt by controlling the area in which easterly flowing high gradient tributary streams joined the northwesterly flowing low gradient trunk stream. During periods of high water, the tributary streams carried coarse arkosic material into the lower reaches of the basin where it was deposited and interbedded with fine-grained material and lignite being deposited by the sluggish trunk stream. This produced a sequence of coarse-grained arkoses interbedded with fine-grained, lignitic mudstones--an ideal host for subsequent uranium deposition.

Ore in the favorable belt has been deposited at the margins of two altered sandstone tongues developed along the axis of the old trunk stream. Their size, shape, and generalized boundaries are shown in Figure 10. The two altered tongues are separated by 50 to 75 feet of siltstone, but hydrologic investigations, relating to solution mining of orebodies, showed that the two sandy intervals are interconnected. The lower altered tongue is in a single sandy interval that rests on the old Pre-Wind River erosion surface. The upper altered tongue is in two sandy intervals that in some places are separated by 30 to 40 feet of sandy siltstone and which in other places rest one on the other.

The upper altered sandstone tongue ranges in thickness from a few feet near its western edge to about 70 feet several hundred feet from the edge. It is generally concordant with the low dip of the Wind River Formation, but in some places the altered-unaltered sandstone contact cuts sharply across sedimentary structures. At its northern end the upper altered tongue lies at a depth of about 450 feet. Toward the south it climbs at a rate of about 70 feet per mile. The length of the upper altered tongue at one time may have been considerably longer than shown on Figure 10, for toward the south it loses its identity when it passes into the zone of surface weathering and eventually crops out.

The positions of the altered tongues within the Wind River sandstones appear to be related to permeability factors in the host sediments. There is a noticeable fining of the host sands in both the upper and lower altered tongues toward the east and in the lower altered tongue toward the north. The position of the northern part of the upper tongue is governed by a pinchout by onlap of the sands on a high area of the Pre-Tertiary erosion surface. Toward the west the sands in the upper tongue pinchout while those of the lower tongue continue for several miles but rise with the increase in elevation of the Pre-Wind River erosion surface.

Size analyses run on 21 samples of sandstone (14 altered and 7 unaltered) showed no obvious differences in the physical properties of the sands. Figure 11 shows typical frequence and cumulative distribution curves. It may be concluded from these data that: (1) alteration has not noticeably affected the physical properties of the sand, and (2) that physical properties on a local scale have not determined the location of the altered sandstone tongues, although on a regional scale those properties must have had a major influence on their locations.

Color is the most striking difference between altered and unaltered sandstone in the Shirley Basin. Unaltered sandstone, where unweathered, is generally 


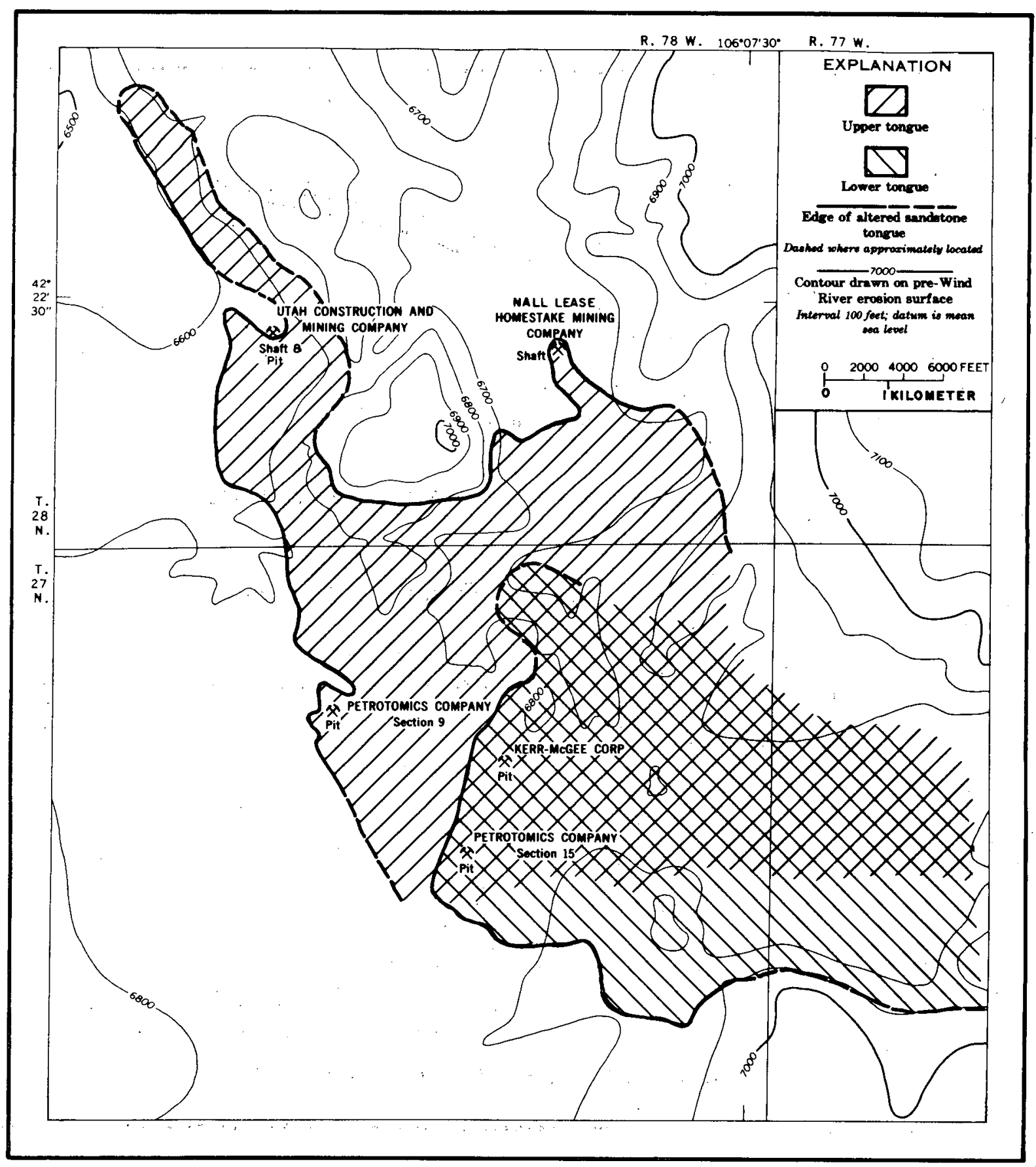

Figure 10. Map showing limits of altered sandstone associated with an upper and lower roll-type system in the Wind River Formation, Shirley Basin, Wyoming (modified from Harshman, 1972). 
medium to light gray, while altered sandstone is almost everywhere greenish yellow, although in one area near the Nall lease (FIg. 10) it is orange, red, or reddish brown. In most places the color difference can be easily recognized in undisturbed samples or in drill cuttings, but in some places the color difference is very subtle and can be recognized only in cuttings containing considerable silty material. When samples of altered and unaltered

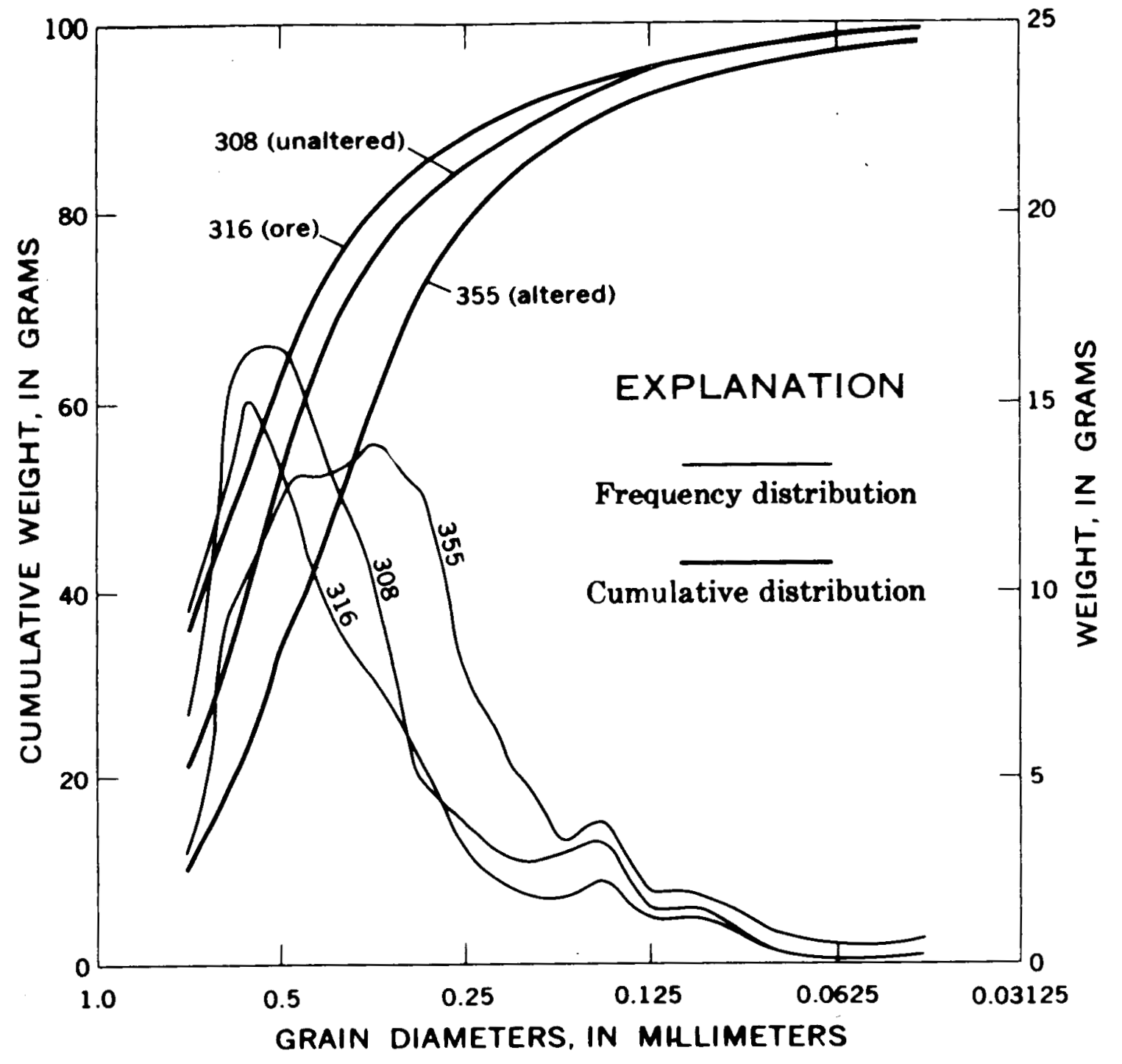

Figure 11. Cumulative and frequency distributions of three samples of sandstone from the ore-bearing sandstone interval, Petrotomics Co. Section 9 pit, Shirley Basin, Wyoming (from Harshman, 1972). 
sandstone are screened, the diagnostic colors are retained by silt-and claysized fractions. The minus $0.074 \mathrm{~mm}$ (200 mesh) fraction of an altered sandstone sample contained 36 percent of the iron in the total sample although that fraction constituted only 3.3 percent of the weight of the total sample. In sharp contrast, the minus $0.074 \mathrm{~mm}$ fraction of an unaltered sandstone contained only 12 percent of the total iron in the sample. X-ray analyses of the clay-sized $(-0.002 \mathrm{~mm})$ fraction of altered sand show the clay mineral to be high-iron montmorillonite. Similar analyses of unaltered sand show the clay mineral to be montmorillonite low in iron. These data suggest that the color differences between altered and unaltered sandstone result from the amount and oxidation state of iron in the fine-grained fraction of the sandstone. The iron probably substitutes for aluminum in the clay lattice.

Although not found in the minus $0.002 \mathrm{~mm}$ fraction, considerable kaolinite was found in the minus $0.074 \mathrm{~mm}$ (200 mesh) fractions of both altered and unaltered sandstone. Thin sections of the friable sandstones were poor, but the clay minerals seemed to be evenly distributed between the sand grains and to have been deposited with the sand. S. R. Austin (written communication, 1980) reports that some iron-rich montmorillonite originated by alteration of amphibole minerals. Alteration of feldspar, particularly microcline, even in the altered sandstone was minimal, a surprising fact considering the other changes in the sandstone produced by the mineralizing solutions.

Table 1 summarizes the results of a study of 39 samples of ore, altered sandstone, and unaltered sandstone. This study, made to determine the changes caused by alteration, confirms what can be seen in drill cuttings and mine exposures. The data suggest that alteration has destroyed pyrite and calcium carbonate, had little effect on the heavy minerals other than pyrite, and has not increased significantly the clay and fine silt $(-0.008 \mathrm{~mm})$ fraction of the sandstone.

Field and laboratory evidence show that carbonaceous materia1, common in the Wind River sandstones has been largely destroyed during the alteration processes. Cross-beds containing considerable vitreous carbonaceous material with a woody texture on the unaltered side of an altered-unaltered contact continue into the altered sandstone, but the carbonaceous material becomes dull and sooty and within a foot or so from the contact has been almost totally destroyed. Chemical analyses for organic carbon confirm this destruction.

$\mathrm{Fe}^{+2} / \mathrm{Fe}^{+3}$ ratios in the host sandstones changed considerably during alteration. Analyses of several suites of samples across orebodies in the Shirley Basin show that unaltered sandstone has a $\mathrm{Fe}^{+2} / \mathrm{Fe}^{+3}$ ratio of from $2.0: 1$ to $4.5: 1$, but in sharp contrast the ratios in altered sandstone range from 1.5:1 to less than $0.4: 1$.. The total iron contents of altered and unaltered sandstone are about the same.

Altered and unaltered sandstone differ markedly in their selenium contents. Analyses of several hundred samples show that selenium in unaltered Wind River rocks ranges from about 1 to $4 \mathrm{ppm}$; the higher amounts are generally in the fine-grained carbonaceous beds. Selenium in the altered sand is about one order of magnitude higher, ranging from 10 to $40 \mathrm{ppm}$. 
Table 1. Physical and mineralogical data on 39 samples of unaltered, altered, and mineralized sandstone, Shirley Basin, Wyoming (from Harshman, 1972).

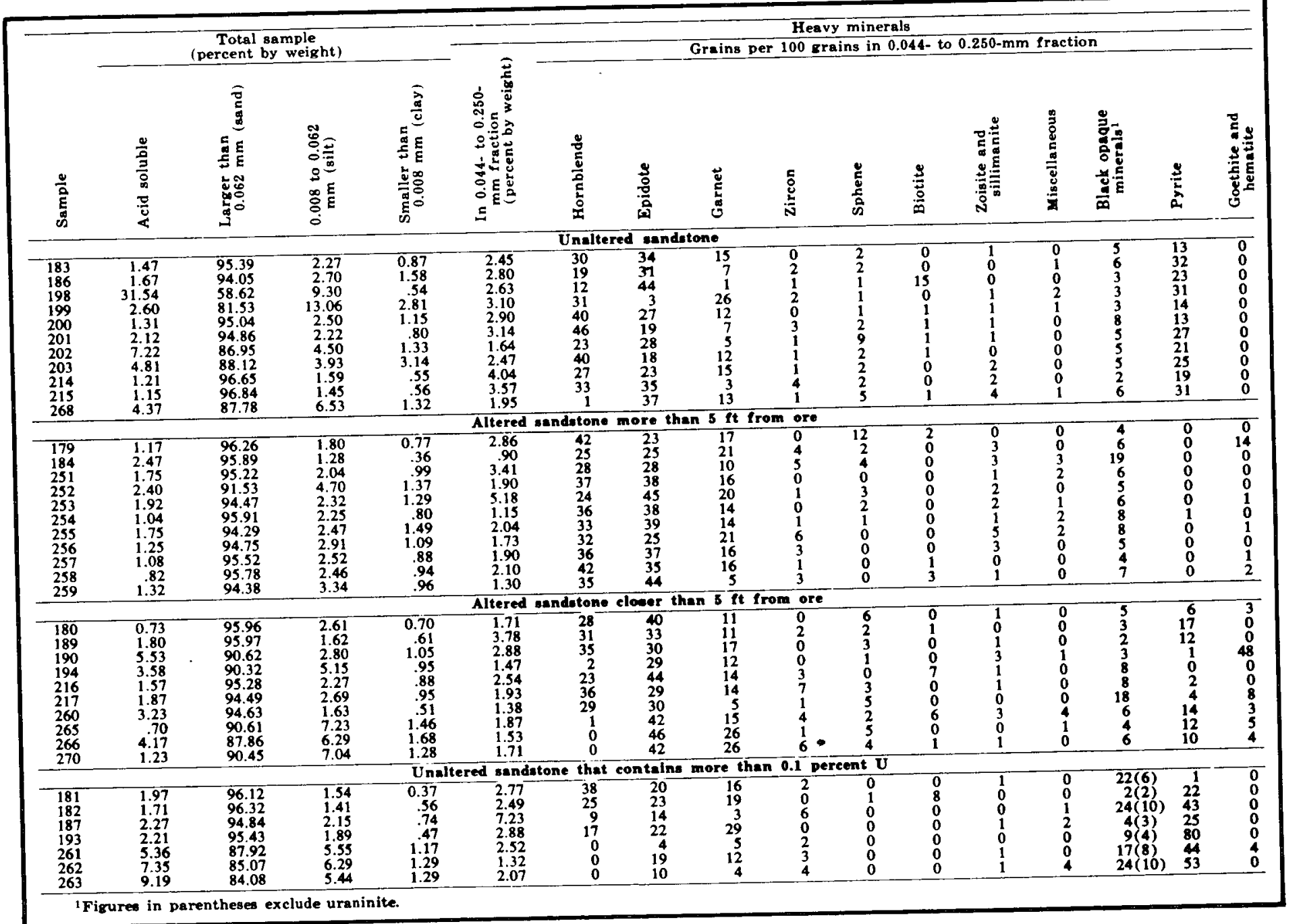


Uranium and its daughter products are higher in altered sandstone than in unaltered sandstone distant from ore. Unaltered, unmineralized sandstone from the ore-bearing interval and barren sandstone above the ore-bearing interva1 contain from 4 to $5 \mathrm{ppm}$ uranium and averages about $5 \mathrm{ppm}$. Altered sandstone several thousand feet behind the roll front contains from 6 to $15 \mathrm{ppm}$ uranium and averages about $7 \mathrm{ppm}$.

Figure 12 is a plot of the U:eU ratios of 175 samples from the Shirley Basin deposits. It clearly shows a disequilibrium in favor of eU in samples containing less than 0.1 percent uranium, a common occurrence in many uranium

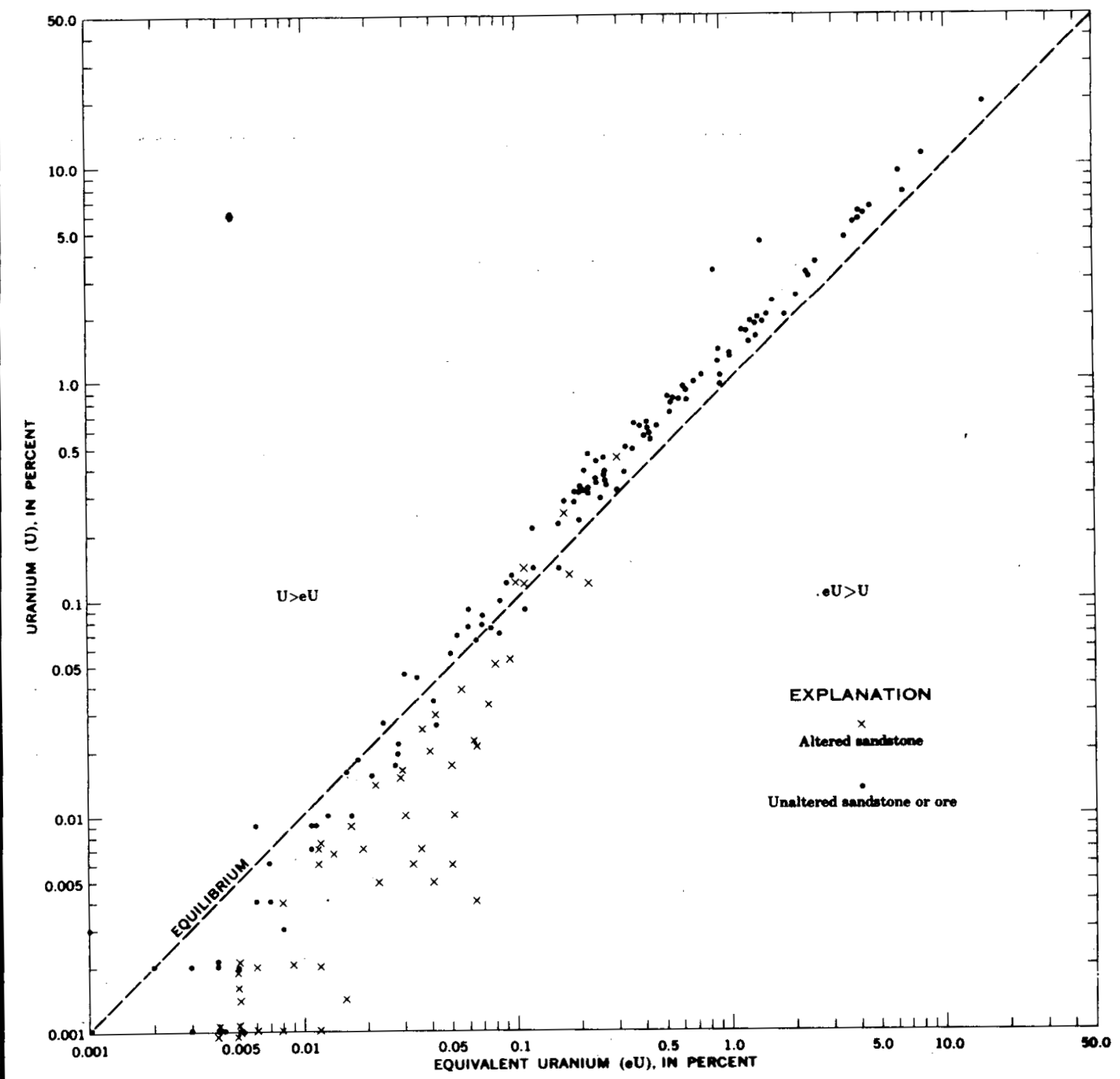

Figure 12. Equilibrium relations of 175 samples of mineralized sandstone from Shirley Basin, Wyoming (from Harshman, 1972). 
deposits, but more to the point it shows that in these weakly mineralized samples the disequilibrium is greater in the altered than in the unaltered sandstone.

Other elements that have been affected by alteration of the host sandstone are copper, sulfate sulfur and arsenic, which were removed during alteration, and vanadium, present in very minor amounts, which was added during alteration. These and other elements related to the ore-forming processes will be discussed later in this report.

The major ore deposits are at the edges of the altered sandstone tongues in zones that separate altered from unaltered sandstone. The inner contacts of ore and altered sandstone are generally sharp; but the outer contacts of ore and unaltered sandstone are gradational. In its simple form an orebody is crescentic in cross section, and in plan it is elongate parallel to the margins of the altered sandstone tongues. Ore boundaries generally cut the bedding of the host sandstone at sharp angles although the horns of the crescent may be peneconcordant with the bedding. Many of the orebodies are complex and consist of several rolls connected by thin zones of mineralization. Simple and complex ore rolls are shown in Figure 13. Small ore pods are found on the

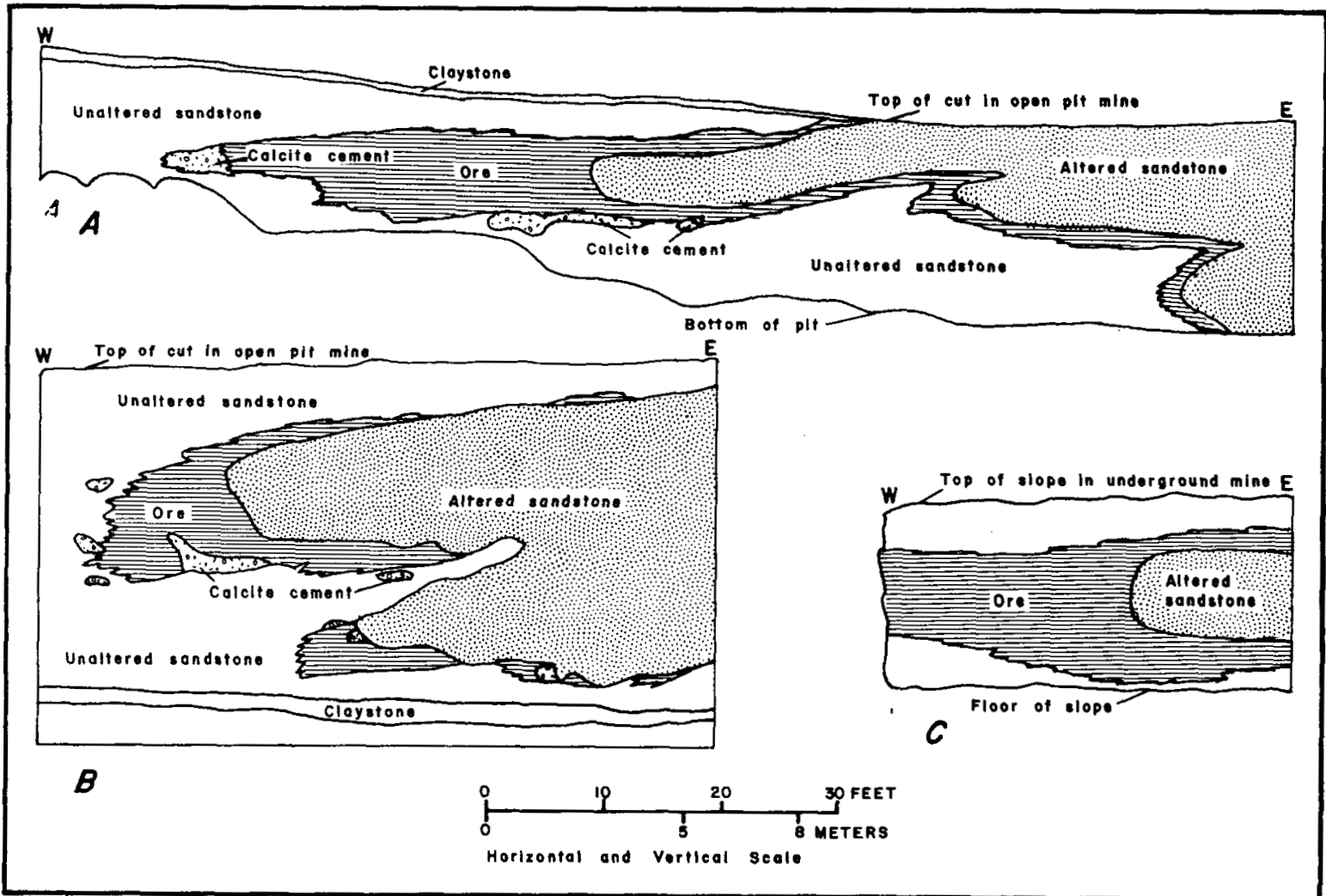

Figure 13. Cross sections at west edge of upper altered-sandstone tongue, Shirley Basin, Wyoming (see Figure 7). Sections $A$ and $B$ are in Petrotomics Co. Section 9 open pit mine. Section $C$ is a simple " $\mathrm{C}$ " roll in the Utah International (now Pathfinder) underground mine (from Harshman, 1972). 
top and bottom surfaces of the altered sandstone tongues some distance from their edges, and small ore pods are associated with small irregular bodies of unaltered sandstone of low permeability that extend into, the altered tongues or may be present as islands within the tongues. Such an ore pod is shown in Figure 14.

Individual orebodies in the Shirley Basin are not extensive either in lateral dimension or in total tonnage. Ore may extend a few hundred feet from the edge of an altered sandstone tongue, may extend laterally for 2000 or 3000 feet, and may be as much as 30 feet thick. Orebodies of this size contain several hundred thousand tons of ore. Most orebodies are considerably smaller. Ore in place contains from a few hundredths to as much as 20 percent $\mathrm{U}_{3} \mathrm{O}_{8}$. The grade of ore mined in the Shirley Basin ranges from a few hundredths to a few tenths of a percent $\mathrm{U}_{3} \mathrm{O}_{8}$ and reflects mining, milling, and marketing costs more than geologic factors. The highest grade ore may or may not be immediately adjacent to the altered sandstone. In this characteristic, the Shirley Basin deposits are similar to those described by Kashirtseva (1964) from undesignated areas in Russia. If orebodies at the margins of the altered tongues are asymmetric in cross section, there appears to be some tendency for the highest grade and largest orebodies to occur on the lower 1imb or "horn" of the crescent as shown in Figures 13A and 13C. Exceptions are common. Ore not at the margins of the altered tongues seems to be equally distributed along the top and bottom surfaces of the tongues.

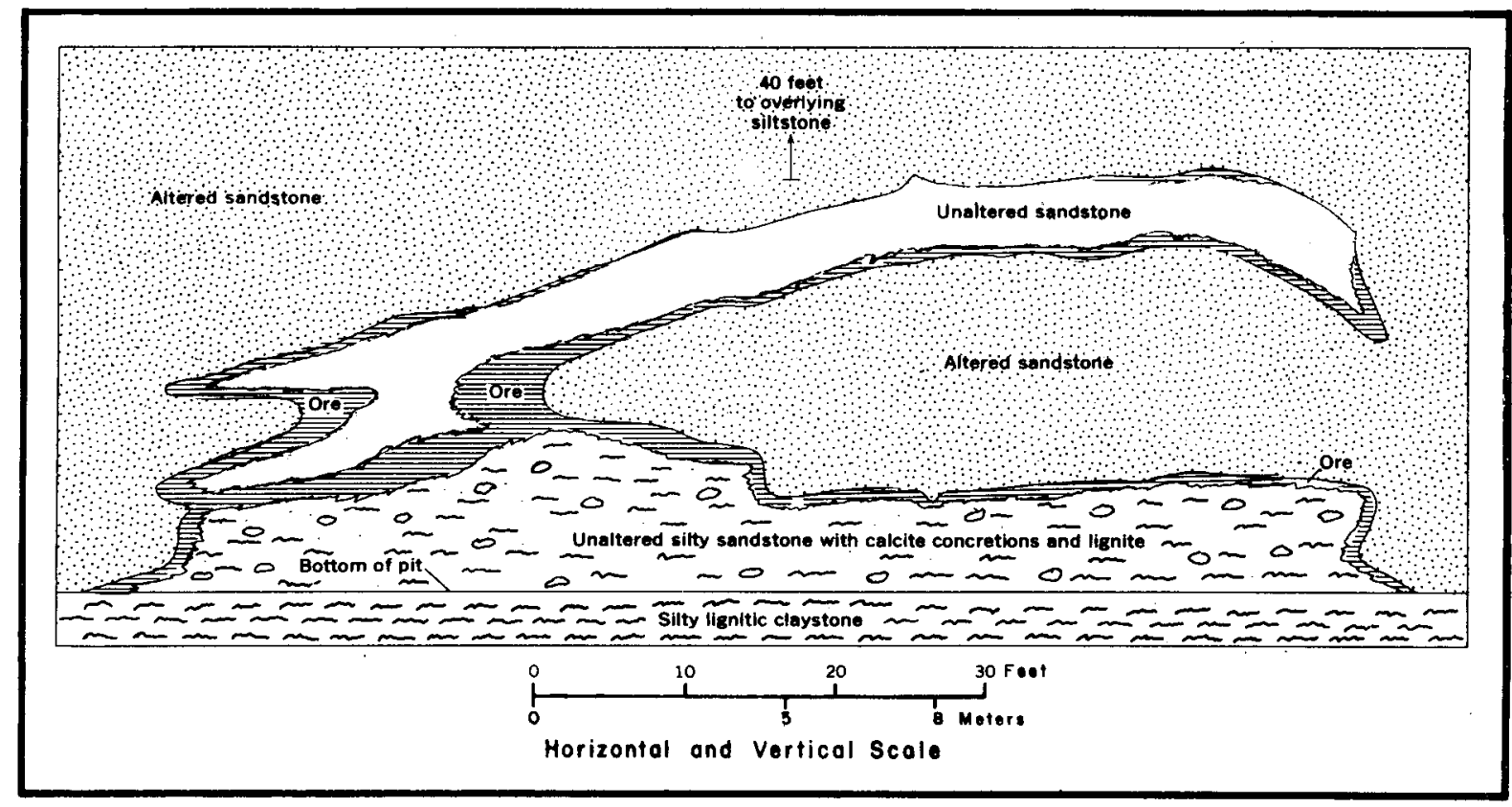

Figure 14. Small ore pods along the bottom of the altered-sandstone tongue about 1200 feet back from the edge of the tongue, Petrotomics Co. Section 9 pit, Shirley Basin, Wyoming (from Harshman, 1972). 
The Shirley Basin deposits are mineralogically simple. The principal epigenetic minerals are pyrite, marcasite, uraninite, native selenium, ferroselite, hematite, and calcite. Pyrite is abundant in the ore and widely distributed in small amounts in the host sandstone, as well as in altered sandstone very near ore. Unaltered sandstone contains about 1 percent pyrite disseminated through the rock, replacing carbonaceous material, surrounding clay galls, and in some places cementing graveliy cross beds. The pyrite is untarnished, generally euhedral to subhedral, and much of it is in very small grains attached to the sand grains. Some pyrite replaces clay and some occurs as grain aggregates. The widely distributed pyrite is considered to be diagenetic and to have formed prior to ore deposition.

Pyrite related to ore deposition is abundant, in some places more abundant than uranium. It occurs in the ore as small euhedral to subhedral crystals, as small aggregates of grains, as coatings on sand grains and as botryoidal masses filling open spaces in the host rock. Most of the euhedral pyrite is untarnished or only slightly tarnished, but the pyrite coating sand grains is tarnished irridescent or bluish-black. In polished sections of ore, pyrite is seen to replace feldspar along cleavage fractures and to form single and multiple rims on sand grains. Multiple pyrite rims are generally separated by a rim of uraninite.

Mineralized sandstone with the highest pyrite content is most commonly in contact with altered sandstone, but in some places it is separated from altered sandstone by a few feet of material with a lower pyrite content. On the outer extremity of the orebodies, pyrite extends farther from the altered sandstone tongue than does any other ore mineral except possibly calcite.

Marcasite is present in ore in minor amounts. It is most abundant in ore near the contact with altered sandstone where it occurs in small lath-like grains intergrown with pyrite or in small isolated grains dispersed through calcite.

Uraninite is the only identified uranium mineral in the Shirley Basin ore although coffinite well may be present. Some uranium may be present as an organic-uranium complex, or chelate, but the presence of such material remains unconfirmed. X-ray diffraction studies suggest that the uraninite contains considerable $\mathrm{UO}_{3}$. Uraninite fills the pores of the host sandstone, coats and fills fractures in sand grains, and replaces parts of grains--particularly feldspar. Uraninite forms the inner rim on some sand grains, but in most cases it forms an outer rim on an inner pyrite and/or marcasite rim. If three rims are present, uraninite lies between an inner and outer pyrite-marcasite rim. In some polished sections, thin veinlets of pyrite-marcasite fill what appear to be shrinkage cracks in uraninite sandwiched between two pyritemarcasite rims. The lateral extent of the zone of deposition of uraninite is only slightly less than that for pyrite.

Selenium is present in a narrow sharply defined zone astride the contact between altered sandstone and ore. In the ore, selenium is present as small acicular crystals of native selenium; in altered. sandstone the selenium mineral is ferroselite. Additional selenium is contained in pyrite, particularly in the unoxidized ore-bearing part of the selenium-bearing zone. Similar selenium mineralogy and distribution have been reported in roll-type deposits in the USSR (Kashirtseva, 1964). 
Calcite is distributed as a cementing material in ore and in a zone or halo surrounding ore (Fig. 13, A and C). Its distribution is less uniform than that of other epigenetic minerals, and it tends to occur in concretionary masses ranging from a few inches to several feet in diameter. In many places calcite is localized around accumulations of carbonized plant debris, and generally this calcite contains hematite. The presence of hematite in this reduced environment has not been explained adequately, but it has also been observed by S. R. Austin (written communication, 1980) at the Peach mine in the Gas Hills, Wyoming. In some samples of high-grade, calcite-cemented ore, calcite replaces feldspar grains around which uraninite previously had been deposited, and this calcite is obviously younger than the uraninite. In other samples, uraninite forms a rind around calcite concretions that are barren in their interior. This calcite is older than the uraninite in the sample. Small corroded calcite concretions are found in a zone a few feet wide that borders the altered sandstone tongues. Almost all of the calcite in and surrounding orebodies, be it younger or older than the uraninite with which it is associated, is thought to be a part of the genetic processes responsible for the Shirley Basin ore deposits as will be described in later paragraphs.

Figure 15 is a graphic summary of epigenetic mineral distribution and deposition in the Shirley Basin ore deposits. In a general way, the tails of the arrows at the left side of the figure indicate the points at which the various elements or compounds began to deposit as a unit of ore-bearing solution flowed toward the right from the altered sandstone tongue to the left. The arrow lengths show the relative widths of the bands through which deposition occurred, and the arrow heads show the points at which deposition stopped for the particular position of the roll front shown. As the roll front advanced to the right, so also did the zone of precipitation for each element or compound.

Selenium was the first element to be deposited from a unit of solution flowing from the altered tongue through the zone of mineral deposition. Pyritemarcasite, uraninite, and calcite followed in that order, but with considerable overlap in time and place of deposition. Hematite was probably deposited last, but its place in the genetic sequence is not well documented. This hematite may have resulted from alteration of earlier iron-bearing minerals as it commonly surrounds dark spots within the calcite.

The sequence of deposition at any given point in the mineralized zone will not be the same as the sequence of deposition from a unit of solution flowing through the mineralized. zone. Because the zone of deposition is a dynamic feature, migrating in the direction of solution flow, the first mineral to be deposited at a given point will be that mineral whose band of deposition extends farthest in the direction of flow, and the last mineral to be deposited will be the one whose band of deposition extends the least distance in the direction of flow. The "downstream" limits on the deposition bands are shown by the arrowheads in Figure 15, and the sequence of initial deposition at a point in the mineralized zone will be selenium, pyrite, hematite, calcite, uraninite and selenium. 


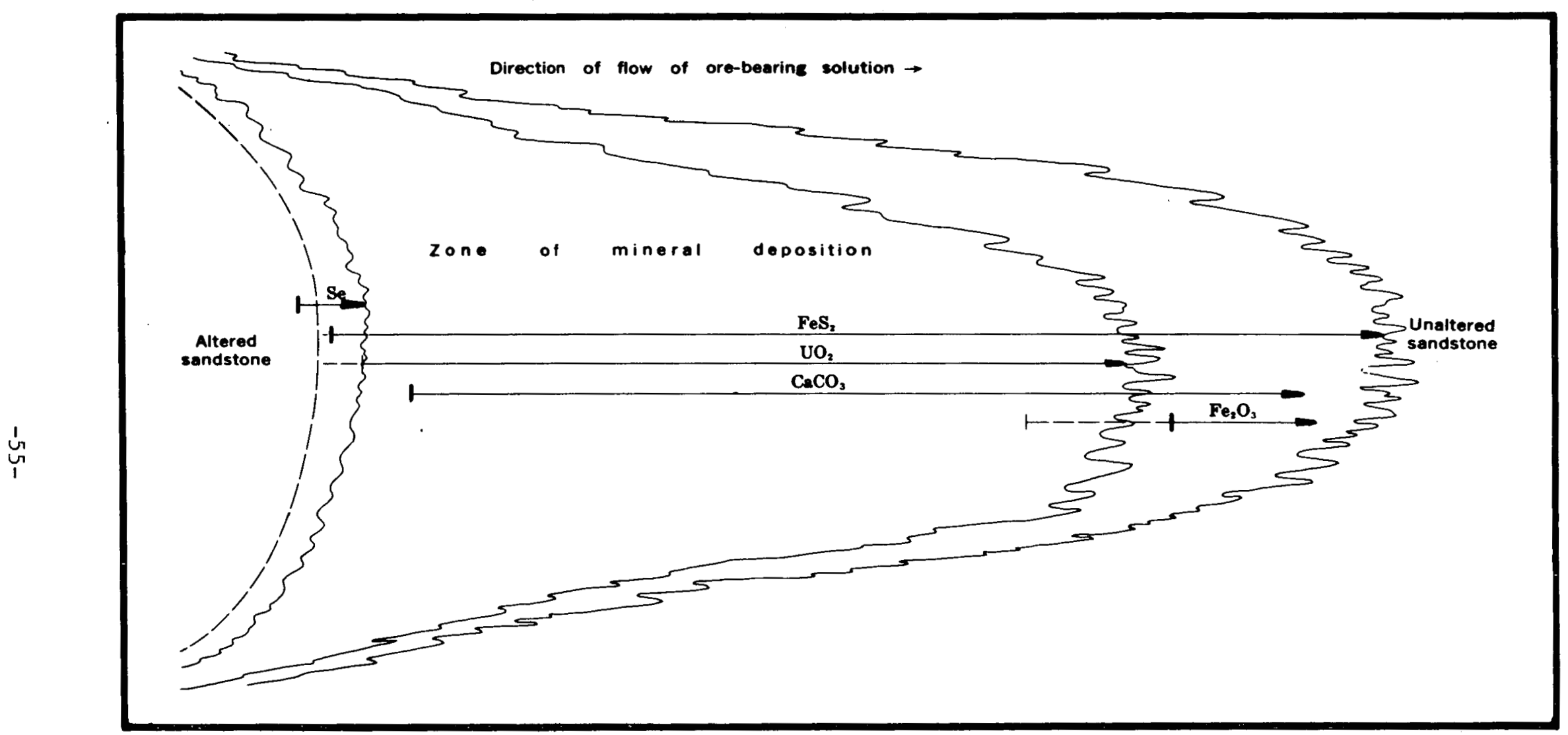

Figure 15. Summary of mineral deposition in Shirley Basin, Wyoming. Lengths of arrows show relative positions and widths of zones through which minerals were deposited; dashed lines are possible deviations from normal conditions. No scale (from Harshman, 1972). 
Gas Hills Area

Selected references: Soister, 1968; Harshman, 1968; Anderson, 1969; Armstrong,. 1970; Rackley, 1972.

The Gas Hills district is on the south flank of the Wind River Basin (Fig. 1). It lies between the Granite Mountains on the south and a series of northwesterly trending folds in Cretaceous and older rocks that separate the district from the axis of the Wind River Basin 10 or more miles to the north (Fig. 16). The district has production and reserves of at least $150,000,000$ pounds of $\mathrm{U}_{3} \mathrm{O}_{8}$ that is being exploited by numerous open pit mines.

The host rock for the Gas Hills uranium deposits is the Wind River Formation of Early Eocene age. Soister (1968) divided the Wind River into three units: (1) a lower fine-grained member, (2) the Puddle Springs Arkose Member, and (3) the upper transition zone. The lower fine-grained member ranges in thickness from 0 to 130 feet and consists principally of mudstone. It is not orebearing. The Puddle Springs Arkose Member ranges in thickness from 400 to 800 feet and is the host for the Gas Hills uranium deposits. The upper transition zone is as much as 120 feet thick in the extreme western part of the area, but in the principal mining district it is thin and Armstrong (1970) has included it with the Puddle Springs Arkose Member.

The lower fine-grained member was deposited on the north flank of the Granite Mountains. (Sweetwater uplift) by meandering streams flowing northward into the Wind River Basin. The basin surface was mature but broken by rocks in a northwest trending sharp fold. The earliest Wind River sediments were deposited in the central part of the Wind River Basin and progressively younger sediments were deposited toward the south where they onlapped the Granite Mountains.

Following renewed uplift of the Granite Mountains and exposure of their granitic core, the Puddle Springs Arkose was deposited on the older rocks. This favorable host is part of two large coalescing alluvial fans whose position were governed by the principal streams flowing northward from the Granite Mountains into the Wind River Basin, and by topographic features which protruded above the general level of the south flank of the Basin (Fig. 16). Here, as in the Shirley Basin, topographic irregularities have had considerable influence on the distribution and character of favorable host rocks. For more detail on deposition of the Wind River sediments in the Gas Hills area, the reader is referred to Rackley (1972).

Galloway (1979) describes the principal facies of the Puddle Springs Arkose as follows:

Intermediate and distal alluvial fan conglomerate and moderately-sorted medium to coarse sandstone grade northward (downslope) into bed-load dominated fluvial channel-fill sands. A few sandy boulder-to-pebble conglomerate horizons, which can be mapped over wide areas, are braidedchannel and sheetwash deposits of individual fan lobes. 


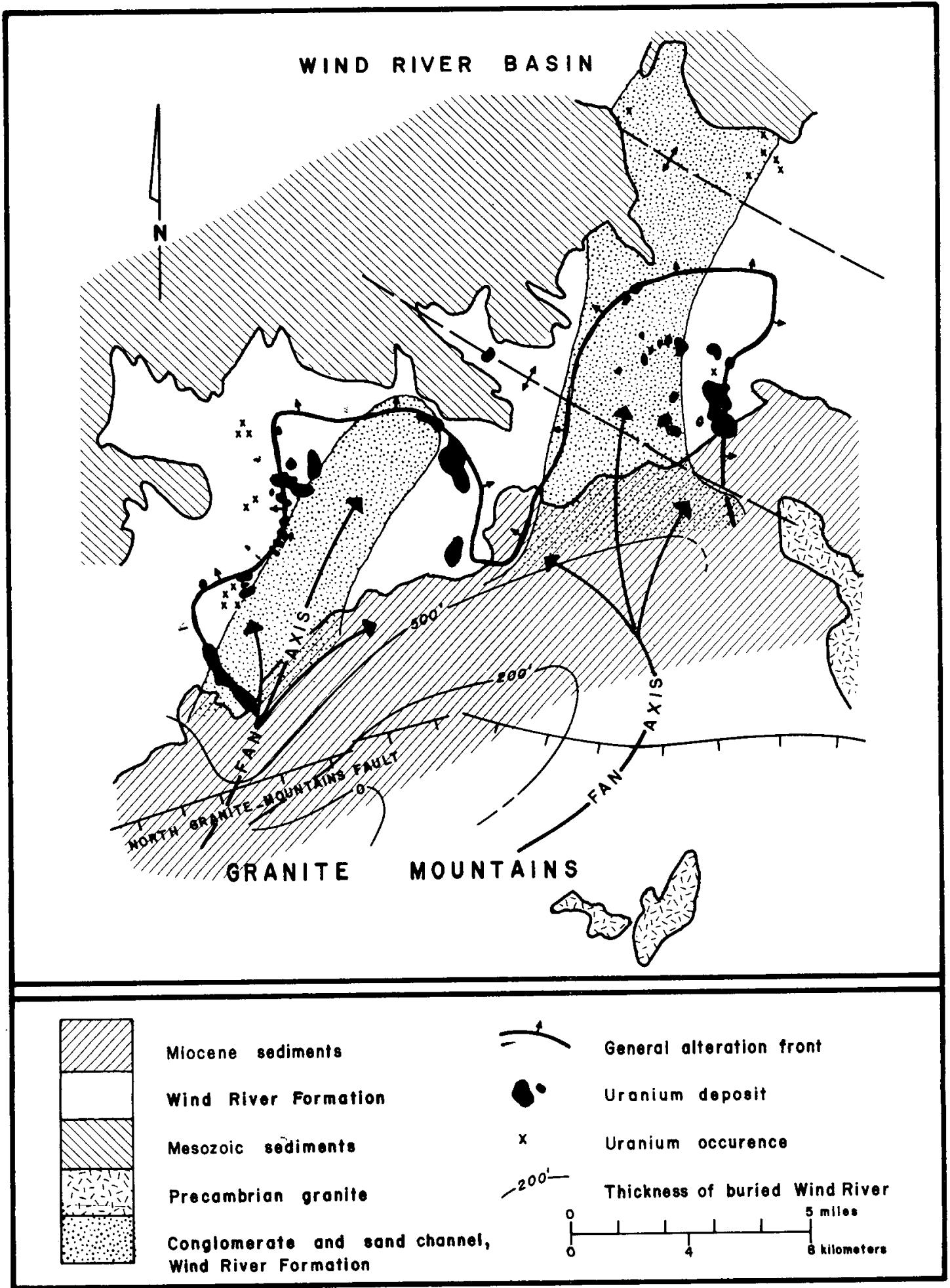

Figure 16. Depositional patterns and distribution of alteration and associated uranium mineralization in the Puddle Springs Formation wet alluvial fan system, Gas Hills uranium district, Wyoming (modified from Galloway, 1979). 
He believes that deposition was by "multiple, laterally migrating, shallow, flashy, straight-channel and braided bed-load streams."

The Gas Hills ore deposits are similar, in many aspects, to deposits in the other Tertiary-filled basins of Wyoming. They are located in three somewhat parallel trends or belts within the large multiple lobate tongue of Puddle Springs Arkose (Fig. 16). The orebodies are located principally at the margins of a large irregular tongue of altered conglomeritic sandstone although some ore occurs on the top and bottom surfaces. The Gas Hills altered sandstone tongue is larger, thicker and considerably more complex than either. of the two altered tongues in the Shirley Basin, a fact undoubtedly related to the more complex sedimentary character of the Gas Hills alluvial fan compared with the distal alluvial fan and bed-load fluvial environment of the Shirley Basin.

The altered sandstone tongue in the central Gas Hills is as much as 300 feet thick and contains many mudstone lenses separating permeable sandstones. It is generally concordant with the dip of the host rock which is now 1 to 3 degrees to the south (toward the source of the arkose). The reversal of dip from the flat northerly depositional dip to the present flat southerly dip occurred after ore deposition as a result of collapse of the Granite Mountains, probably in late Miocene time:

In the Gas Hills one can recognize again a broad control of the altered sandstone tongue's position by the gross permeability of the host rock. There is a noticeable fining of the material in the fan toward the east and west and in the regions where the sediments lap on paleotopographically high areas. As theory would suggest, the position and lobate nature of the altered tongue is controlled by the position of the two principal paleostreams responsible for transporting the arkose into the basin.

The character of the alteration in the Gas Hills is in part unique to this basin and in part similar to that in other Wyoming basins. Color, a diagnostic characteristic of altered sandstone tongues, ranges from creamy to almost white and has been described as "bleached". This is the pervasive color of the altered sandstone and is in marked contrast to most other basins. According to King and Austin (1966), the color results from alteration of feldspar and alteration and/or dissolution of dark detrital minerals. This does not explain, however, the absence of some ferric oxide phase in the altered sandstone. Normal unaltered, unmineralized sand is gray to greenish gray, pyritic, and carbonaceous. Mineralized sandstone ranges from 1ight to dark gray depending on its mineral content.

Various studies have been made on the Gas Hills ores, particularly on those from the central part of the district (King and Austin, 1966; Files, 1970; Harshman, 1974) to determine the distribution of elements and minerals in and near orebodies. Combining the results of these studies, which are not always consistent with each other or within themselves, the following conclusions can be made with reasonable certainty: (1) using unaltered sandstone as a reference, the alteration process has increased the amounts of selenium, vanadium, ferric iron, and perhaps uranium in the altered sandstone; and (2) the altered sandstone is depleted in calcium carbonate, sulfate, pyrite, total iron, organic carbon, arsenic, ilmenite, magnetite, and perhaps copper and molybdenum. 
Available data suggest that other changes may have taken place, but they are not consistent enough to draw firm conclusions. Ferrous/ferric iron ratios are considerably lower in altered than in unaltered sandstone, but the amounts of iron in both the altered and unaltered sandstone are considerably greater than in the Shirley Basin. The disequilibrium in favor of eU in low-grade samples is greater in altered than in unaltered sandstone, but the difference is not as great as in the Shirley Basin. The distribution of these and other elements and minerals in and near the ore deposits will be discussed more fully in a following section of this report.

The Gas Hills orebodies are considerably larger than those in the Shirley Basin, although the grade of the ore mined and the distribution of uranium in the ore are similar. Orebodies are as much as 30 feet thick, but according to Armstrong (1970) the average thickness of "good orebodies" is 10 to 15 feet. The best orebodies extend laterally for several thousand feet with little or no interruption; thinner orebodies are of far less lateral extent. The thickness and complexity of the altered tongue in the Gas Hills (Fig. 17) has given rise to a series of stacked en echelon orebodies that in total form the edge of the altered tongue. As a result, orebodies occur through an interval of about 300 feet even though only one altered tongue is present in the district. In most places rolls are stacked so that successively higher rolls are displaced farther into unaltered sandstone. The area of alteration, therefore, decreases downward in the sandstone. In plan view the roll fronts may parallel one another or they may cross, for each roll front has its own sinuosity. Anderson (1969) notes that uneconomic calcite-cemented uranium and pyritebearing sands "not associated with the altered sand" in the lower part of the Puddle Springs Formation may have formed before the roll-type deposits.

The lower limb of crescent-shaped orebodies generally extends farther back beneath the altered tongue than does the upper limb, and this ore is generally thicker than upper-limb ore. The lower-limb ore is almost always underlain by mudstone, upper-limb ore may or may not be overlain by mudstone, and if not, the upper limb and the upper surface of the altered tongue are separated from the next overlying mudstone by unaltered, unmineralized sandstone.

Uranium is present as uraninite, coffinite, and possibly as a complex with organic matter. Most investigators report uraninite as the most prevalent uranium mineral, but files (1970) reports the uraninite/coffinite ratio to be about 40/60. Other epigenetic minerals in the ore are pyrite, marcasite, jordisite, selenium (probably as ferroselite and native selenium), goethitelimonite, and chlorite. Files (1970) found very fine-grained coffinite associated with the clay fraction of the ore-bearing sandstone. Vanadium and phosphate, although present in small amounts, have been concentrated in the ore. Uraniferous carbonate fluorapatite and autunite were found in surface outcrops at the time of discovery of the district ( $\mathrm{S}$. R. Austin, written communication, 1980), but the mineral form in the unoxidized ore is not known.

The paragenesis of the ore minerals in the Gas Hills deposits appears similar to that in the Shirley Basin (Fig. 15), except for the presence of jordisite in the Gas Hills suite of minerals. Molybdenum, not present in the Shirley Basin, is plentiful in the Gas Hills and jordisite was the last mineral to be deposited from the ore-bearing solution. 


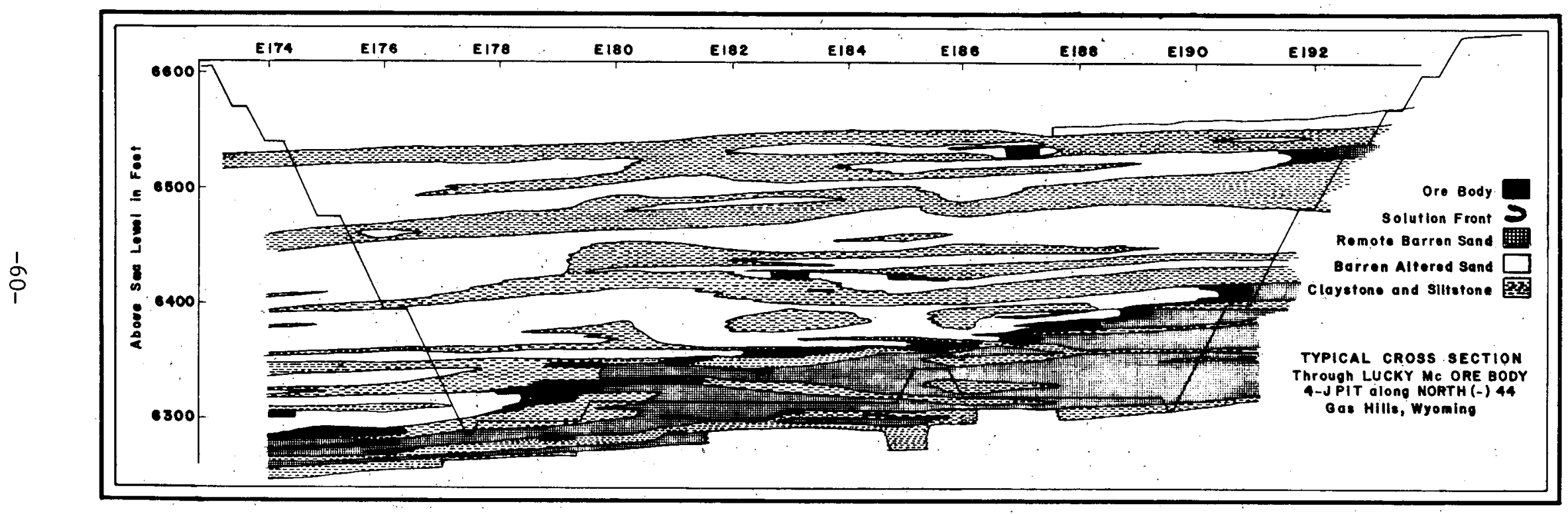

Figure 17. Cross section through the 4-J pit, Lucky Mc (now Pathfinder) mine, Gas Hills uranium district, Wyoming (modified from Anderson, 1969). 
The preceding discussion of the Gas Hills mining district has been limited to those deposits considered to be primary and to have suffered little or no change since their deposition. In addition to the primary deposits there are, however, near-surface oxidized deposits, one of which led to the discovery of the district, and deposits of reduced ore that are generally lenticular and represent uranium redistributed from older roll-type deposits. They will be discussed briefly later in this report. The primary ores, however, are the most important economically for they contain over 90 percent of the ore in the district, and they are all important in any attempt to understand the origin of the deposits and thus determine exploration guides to new deposits.

\section{Powder River Basin}

Selected references: Sharp and Gibbons, 1964; Sharp and others, 1964; Mrak, 1968; Davis, 1969; Langen and Kidwe11, 1974; Dah1 and Hagmaier, 1976.

The Powder River Basin is a topographic and structural basin, open to the north and bounded by the Laramie Mountains on the south, the Hartville Uplift on the southeast, the Black Hills on the east, and the Bighorn Mountains and Casper Arch on the west (Fig. 1). The Tertiary history of the basin began in Laramide time with downwarping of the basin and uplift of bordering highlands. The early Paleocene rocks (Lower Fort Union Formation) consist principally of second cycle fine-grained clays, silts, and muds derived mostly from Cretaceous rocks and deposited by sluggish meandering streams flowing northward through the basin. In Late Paleocene or Early Eocene times, erosion had exposed the granite cores of the ancient Laramie and Granite Mountains and with renewed uplift and increased vigor of the streams arkosic debris began to enter the basin. Deposition was by streams flowing toward the topographic axis of the basin then northward through its open end. According to Galloway (1979), the "influx of coarse, arkosic debris (was) through a well integrated axially trending bed-load to mixed-load fluvial system that is preserved as parts of both Upper Fort Union and Wasatch Formations (as defined by conventional stratigraphic nomenclature)." This bed/mixed load facies grades laterally and downslope into fine mixed-load and suspended-load channel fills. In addition to the channel-fill facies, there are flood plain silts containing small tributary channel sands and silts, as well as swampy lacustrine deposits of muds and coals. The fluvial system in latest Paleocene time (Upper Fort Union) is shown on Figure 18. The Paleocene rocks reach a maximum thickness of about 3000 feet in the southern Powder River Basin and the Wasatch Formation ranges in thickness from 1000 to 1500 feet, thickening from south to north (Sharp and Gibbons, 1964). Dips in the southern and eastern part of the basin are 2 degrees or less but are as high as 20 degrees in the western part.

The ore-bearing sandstones near the southern edge of the Powder River Basin have been placed in the upper part of the Fort Union by some investigators and in the lower part of the Wasatch by others (Dahl and Hagmaier, 1976; Davis, 1969; Denson and Horn, 1975; Langen and Kidwell, 1974). For the purpose of this report, following the work of Denson and Horn (1975), they will be considered to be lower Wasatch, for in reality the precise age has little importance. The orebodies are at the edges and to a lesser extent on the top and 


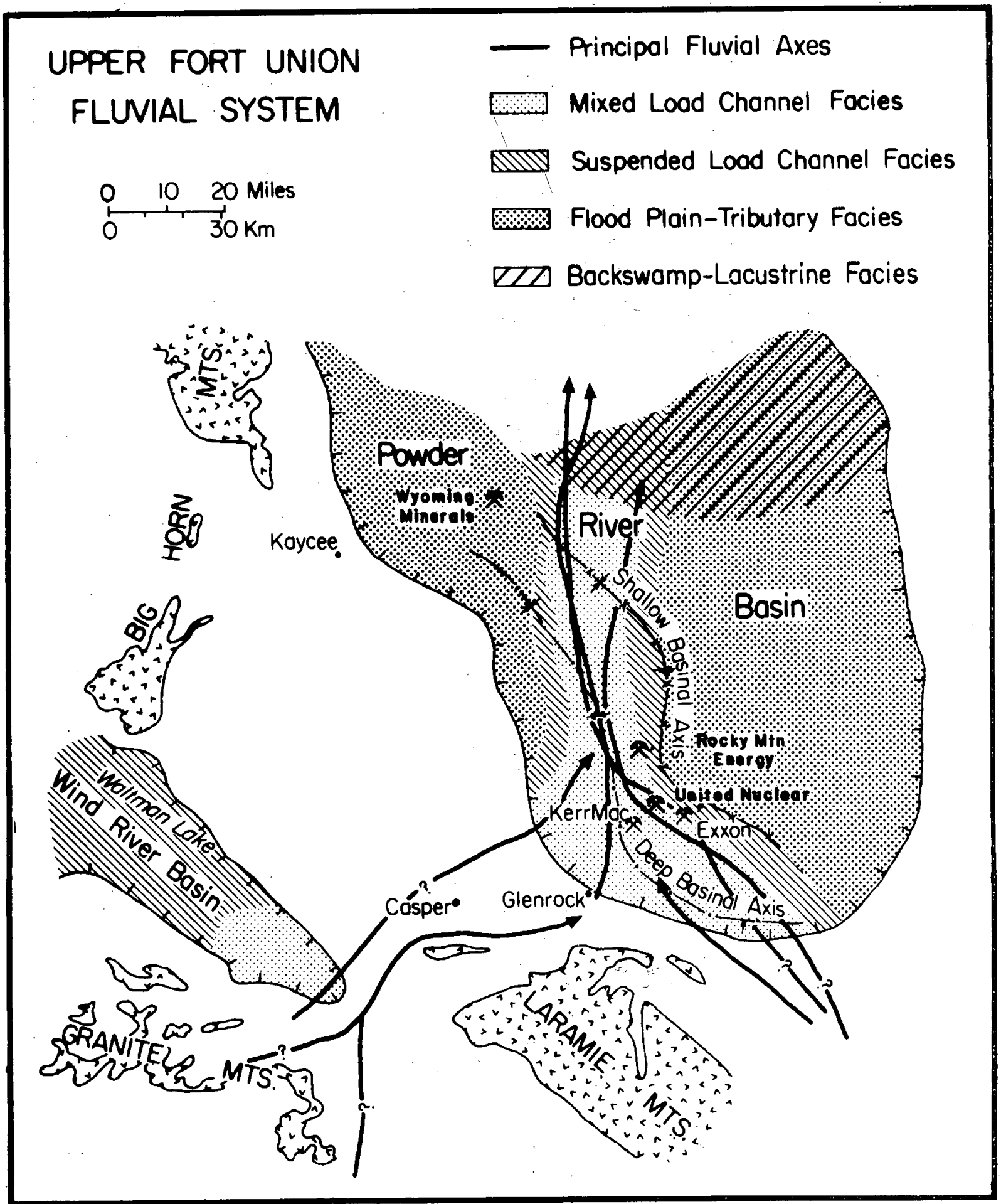

Figure 18. Basin framework, regional facies distribution of the upper Fort Union-Lower Wasatch(?) fluvial system, and uranium operations, South Powder River Basin, Wyoming (modified after Galloway, 1979). 
bottom surfaces of two or more composite tongues of altered sandstone several times larger than those in other Wyoming basins. Altered sandstone tongues occur in an area about 80 miles long and 5 to 20 miles wide (Curry, 1976). Within that area individual sandstone units are as much as 300 feet thick. Principal sand units may be separated by as much as 100 to 200 feet or more of claystones and siltstones (Davis, 1969) although most of them are interconnected. Figure 19 shows the complexity of the Fort Union-Wasatch fluvial system in the southern part of the Powder River Basin, as well as the interconnecting sands.

The basement topographic controls which in part governed the positions of the altered sandstone tongues in the Shirley Basin and Gas Hills areas are absent in the Powder River Basin. The position of the Powder River altered tongues are governed by the geographical locations of the highly transmissive channel sands deposited by the principal streams flowing into the basin from the south and west and then northward along the axis of the basin. The lateral boundaries of the altered tongues are governed by decreases in permeabilities of the sediments away from the stream channel toward areas of overbank, flood plain, and suspended-load deposition. Northward the altered tongues are limited by the predominance of fine-grained, lacustrine, suspended-load meander belt, and swamp sediments. The exceptional length of some of the altered sandstone tongues is due to the continuity of the permeable sands in which an individual bed can be traced along the basin axis for many miles (Davis, 1969).

The altered tongues in the Powder River Basin differ from those of the Shirley Basin and Gas Hills both in color and complexity. The altered tongues in the Powder River Basin are characterized by three distinctive colors that contrast sharply with the light gray of normal unmineralized sandstone. The main body of an altered tongue is red, due to hematite staining on the sand grains. A zone of yellow, goethite-bearing sandstone lies between the red altered sandstone and ore. In some places a zone of white bleached sandstone is present between the goethite-bearing zone and the ore. Figure 20 illustrates the sequence of red, yellow, and bleached alteration zones in an altered sandstone adjacent to ore.

In addition to color changes, the alteration process has increased the content of selenium, uranium, ferric iron and perhaps chromium in the sandstone and decreased the content of manganese, carbonate, organic carbon, and sulfide sulfur. According to Langen and Kidwell (1974) some of the heavy minerals such as pyroxene, hornblende, and biotité, have been destroyed in the altered sandstone. The total iron content of the sandstone does not appear to have been changed by alteration, but available chemical data (Sharp and others, 1964) are from surface outcrops where weathering may have affected the iron content of the samples. The U/eU ratios are generally slightly more than 1 for samples containing more than 0.10 percent uranium and generally slightly less than 1 for samples with less than 0.10 percent uranium, a common characteristic of many uranium deposits in sandstone.

The Powder River uranium deposits are similar in most aspects to those in the other Wyoming basins. Although of ten irregular in outline, they are roughly crescentic in shape, and they lie at the edges of the altered sandstone tongues. Contact with altered sandstone is generally sharp while the leading edge of a deposit progressively contains less and less uranium and finally 


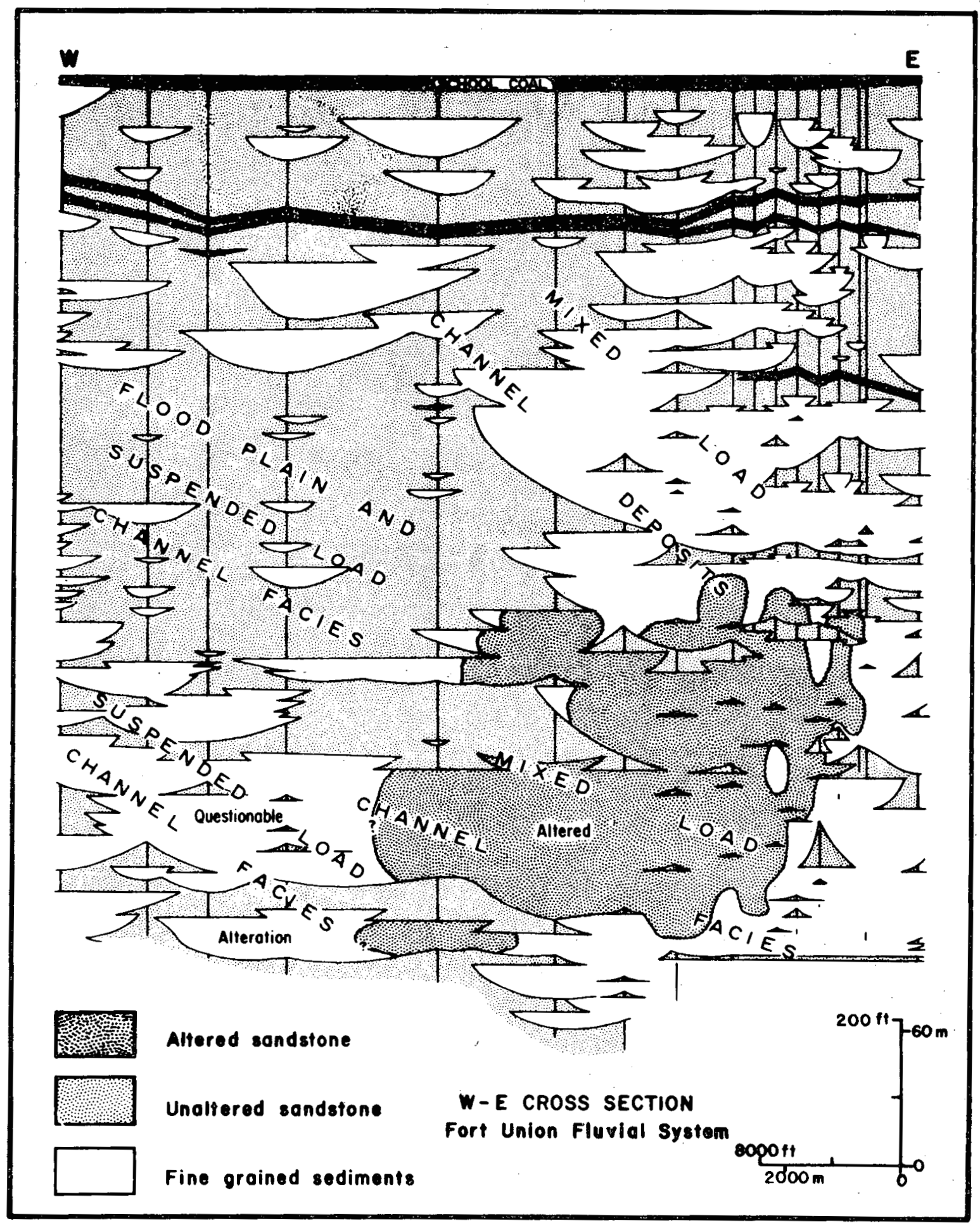

Figure 19. Cross section showing the geometry of fluvial channel-fill facies and stacked alteration fronts in the southwestern part of the . Powder River Basin, Wyoming (modified from Galloway, 1979). 


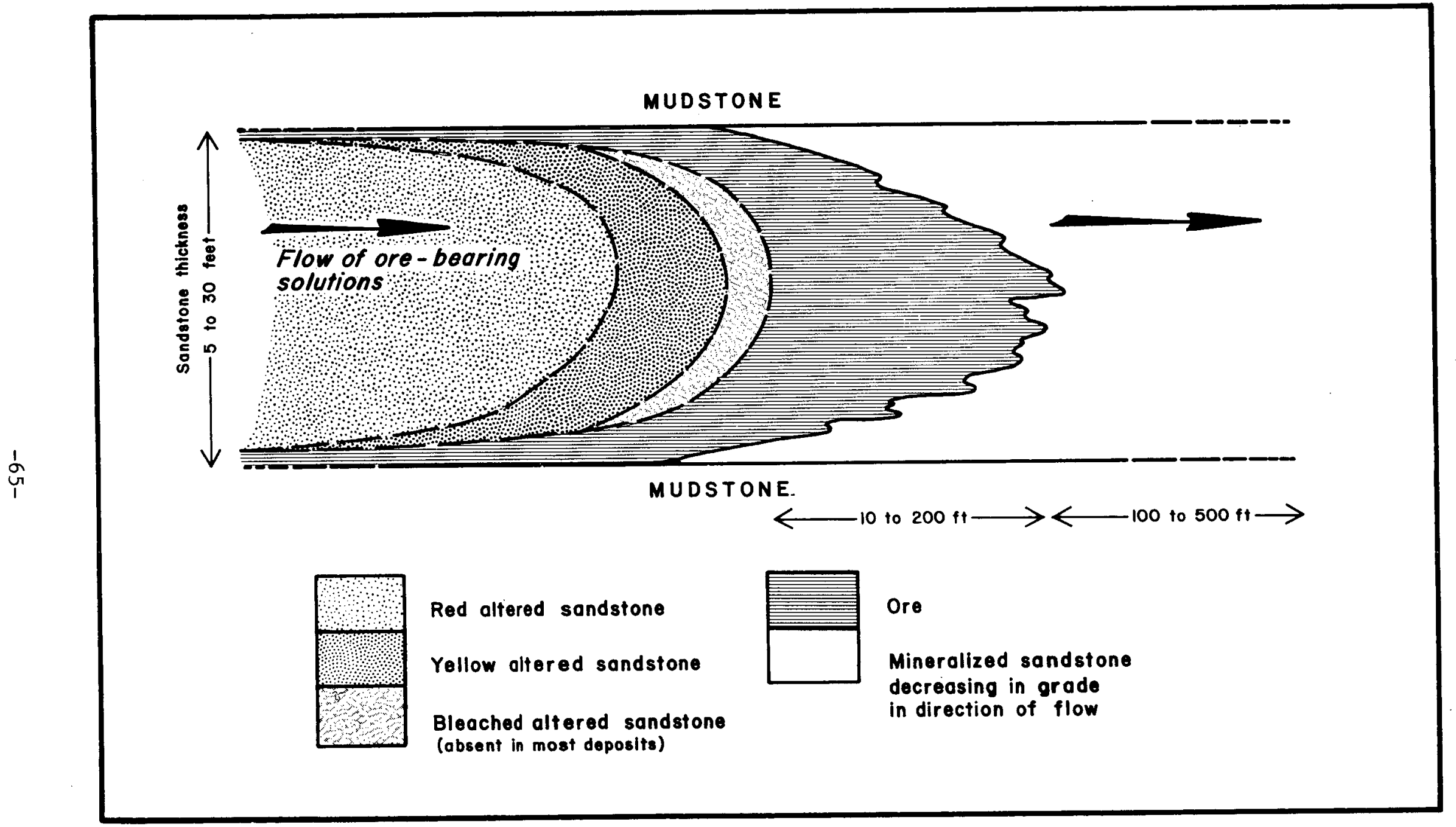

Figure 20. Generalized composite cross section of edge of altered-sandstone tongue and orebody, Powder River Basin, Wyoming, showing character of altered sand near roll front. 
fades into unaltered unmineralized sandstone. Some of the Powder River deposits differ from those in other basins in that they have a relatively wide zone of low-grade mineralized sandstone (less than 0.1 percent $U$ ) between the higher-grade ore and the unmineralized (unaltered) sandstone (Fig. 20). This transition zone, generally a few tens of feet in other districts, can be several hundred feet wide and 10 to 40 feet thick in the Powder River Basin. The width of this zone appears to be inversely related to the width and grade of the higher-grade ore it adjoins (Davis, 1969). The edge of an altered sandstone tongue (or roll-front) is generally mineralized, but it is not everywhere ore-bearing. Orebodies may extend for several thousand feet along the edge of an altered tongue and be as much as 30 feet thick; generally they are less extensive.

The principal ore minerals are uraninite, coffinite, and pyrite-marcasite, native selenium, calcite and possibly some unidentified vanadium mineral. The ore minerals fill open spaces in the sandstone, coat sand grains, and fill cracks in as well as replace parts of the sand grains. The distribution of several elements and minerals in the ore and adjacent sandstone will be dealt with more fully later in this report.

Near-surface oxidized deposits have been discovered and mined in the Powder River Basin and, as in the Gas Hills, such deposits (Pumpkin Buttes area) led to the discovery of the district. Economically, these secondary deposits are more important than those in the Gas Hills, but they are unimportant to an understanding of the primary roll-type deposits in the basin.

Ore reserves and ore already mined in the Powder River Basin total at least $150,000,000$ pounds of $\mathrm{U}_{3} \mathrm{O}_{8}$. This resource is being exploited by open pit, underground, and solution mining methods.

Crooks Gap-Great Divide Basin

Selected references: Stephens, 1964; Bailey, 1969; Pipiringos and Denson, 1970; Love, 1970; Childers, 1974; Sherborne et a1, 1980.

The Great Divide Basin is about 3500 square miles in area and is bounded by the Granite and Wind River Mountains on the north, and Wamsutter Arch on the south, the Rawlins Uplift on the east, and the Rock Springs Uplift on the west (Fig. 1). It is a structural and topographic basin with interior drainage, and it is located astride the Continental Divide. The basin contains three types of uranium deposits: (1) low-grade $(0.003 \pm \% \mathrm{U})$ deposits in coal, described by Masursky (1962); (2) secondary, near-surface deposits of schroeckingerite, described by Sheridan et al (19.61); and (3) roll-type, to be discussed in this report.

The roll-type uranium deposits in the Crooks Gap-Great Divide Basin area are in the Battle Spring Formation of Early Eocene age. Because the Battle Spring is a mountainward facies of the Wasatch Formation, some geologists do not accept its formational rank (Love, 1970). The Battle Spring is a composite wet alluvial fan deposited by at least three principal streams flowing southward from the Granite Mountains into the ancestral Great Divide Basin. It is 
the stratigraphic equivalent of the Puddle Springs Arkose that was deposited at about the same time in the Gas Hills area on the north flank of the Granite Mountains. The Battle Spring Formation is as much as 4000 feet thick. It was deposited on the slightly folded fine-grained rocks of the Paleocene Fort Union Formation where present, and on the folded pre-Tertiary rocks where the Fort Union was absent. It is, or was, overlain by tuffaceous rocks of late Eocene, Oligocene, Miocene, and Pliocene age, lithologically similar to those in the Gas Hills and Shirley Basin areas.

Concurrent with deposition of the coarse debris in the alluvial fans close to the Granite Mountains, the Wasatch Formation was deposited in the center of the basin. The Wasatch is of fluvial, lacustrine, and paludal origin, and it contains several tongues of the Green River Formation. The main body of the Green River Formation 1ies to the southwest in the Green River Basin. The Wasatch and Battle Spring Formations interfinger and intertongue in a belt 15 to 20 miles wide, trending northwesterly, and located 20 to 30 miles southwest of the northern edge of the Great Divide Basin (Figs. 21 and 22).

The first roll-type orebodies to be discovered and mined, and the ones about which the most data are available, are those in the Crooks Gap area on the northeast flank of the Great Divide Basin. These deposits are in the lower 1500 feet of the.Battle Spring Arkose in sediments that range from mudstone through coarse-grained sandstone to very large boulder conglomerates. Much of the Battle Spring is poorly sorted, and there are abrupt changes in the character and permeability of the arkosic debris. This material contains some carbonaceous trash and some carbonaceous siltstone and mudstone, but generally there is not much plant debris. In McGowen's (1979) depositional system, it would be classified as a proximal or medial wet fan sediment.

Within the Battle Spring arkosic pile are some areas of fluvial conglomerate, sandstone, silt, and clay that show moderate sorting as well as moderate to good 1ithologic continuity. These rocks are related to several principal streams that flowed from the Granite Mountains southward into the Great Divide Basin. There is considerable carbonaceous material associated with these sediments, and they appear to have been deposited by bed-loaded streams in an aggrading fluvial system. Most of the uranium deposits in the Crooks Gap area of the Great Divide Basin are in these fluvial rocks. Dips in the Crooks Gap area are steeper than in other Wyoming basins, ranging from a few to as much as 20 degrees southeasterly. The steep dips are believed to have resulted from post-ore faulting that occurred along the South Granite Mountain fault on the southern flank of the Granite Mountains (Fig. 22).

In addition to the roll-type uranium deposits in the Crooks Gap area, similar deposits are found in fluvial sandstones located well down the northern flank of the Great Divide Basin, where the coarse-grained rocks of the Battle Spring Formation interfinger with and/or grade into the finer-grained fluvial, paluda1, and 1acustrine rocks of the Wasatch Formation (Fig. 21). In this part of the Great Divide Basin the sediments are better sorted and individual beds have better lateral continuity than do the sediments near the edge of the basin, features which are characteristic of distal fan and bed-load stream sedimentary environments. 


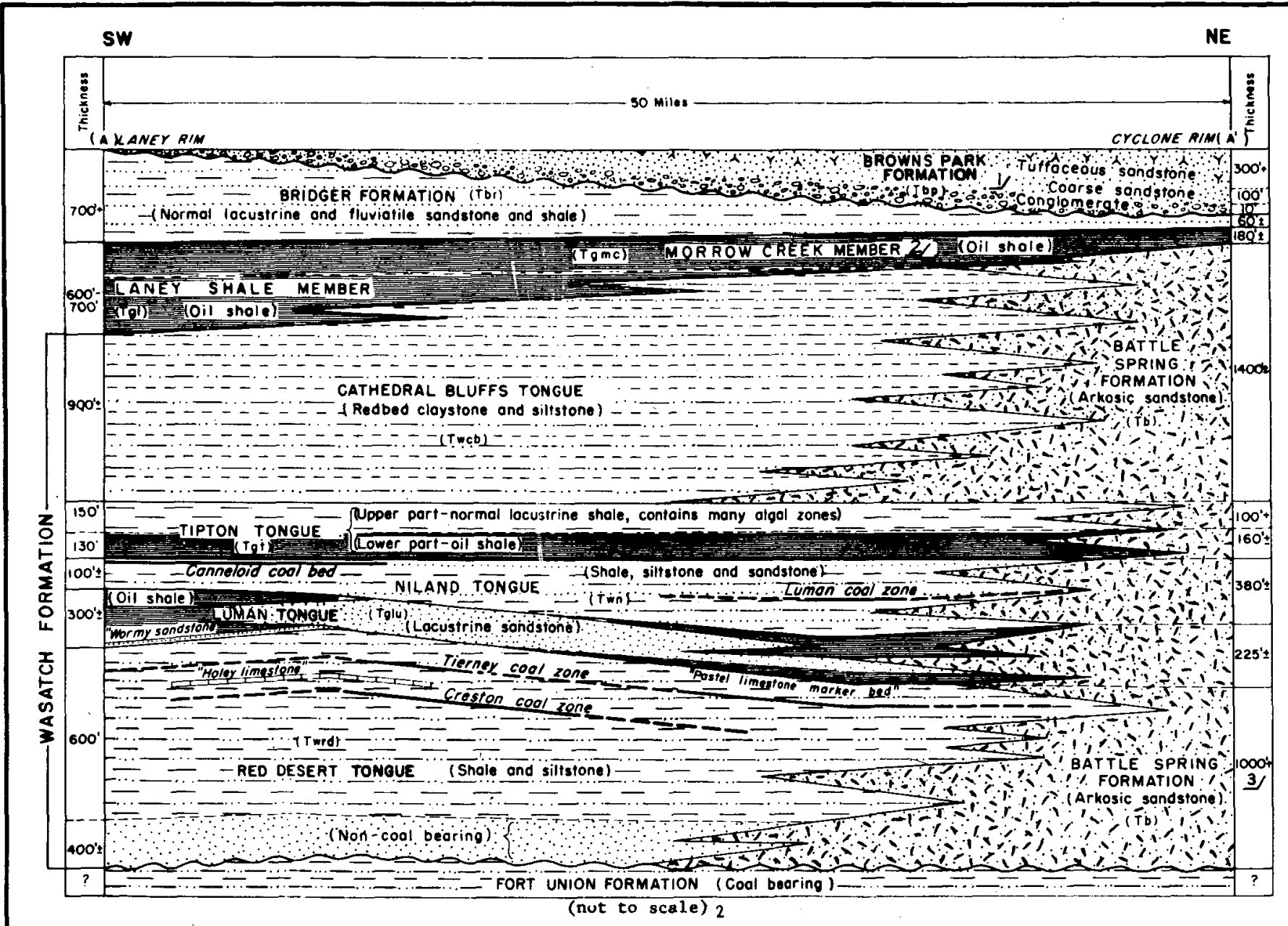

Figure 21. Cross section of Battle Spring, Wasatch, and younger formations in the central part of Great Divide Basin, Wyoming, showing interfingering of the Wasatch and Battle Spring Formations and the tongues of Green River Formation ( $\mathrm{Tglu}$ and $\mathrm{Tg} 1$ ) within the Wasatch Formation (modified from Pipiringos and Denson, 1970). 


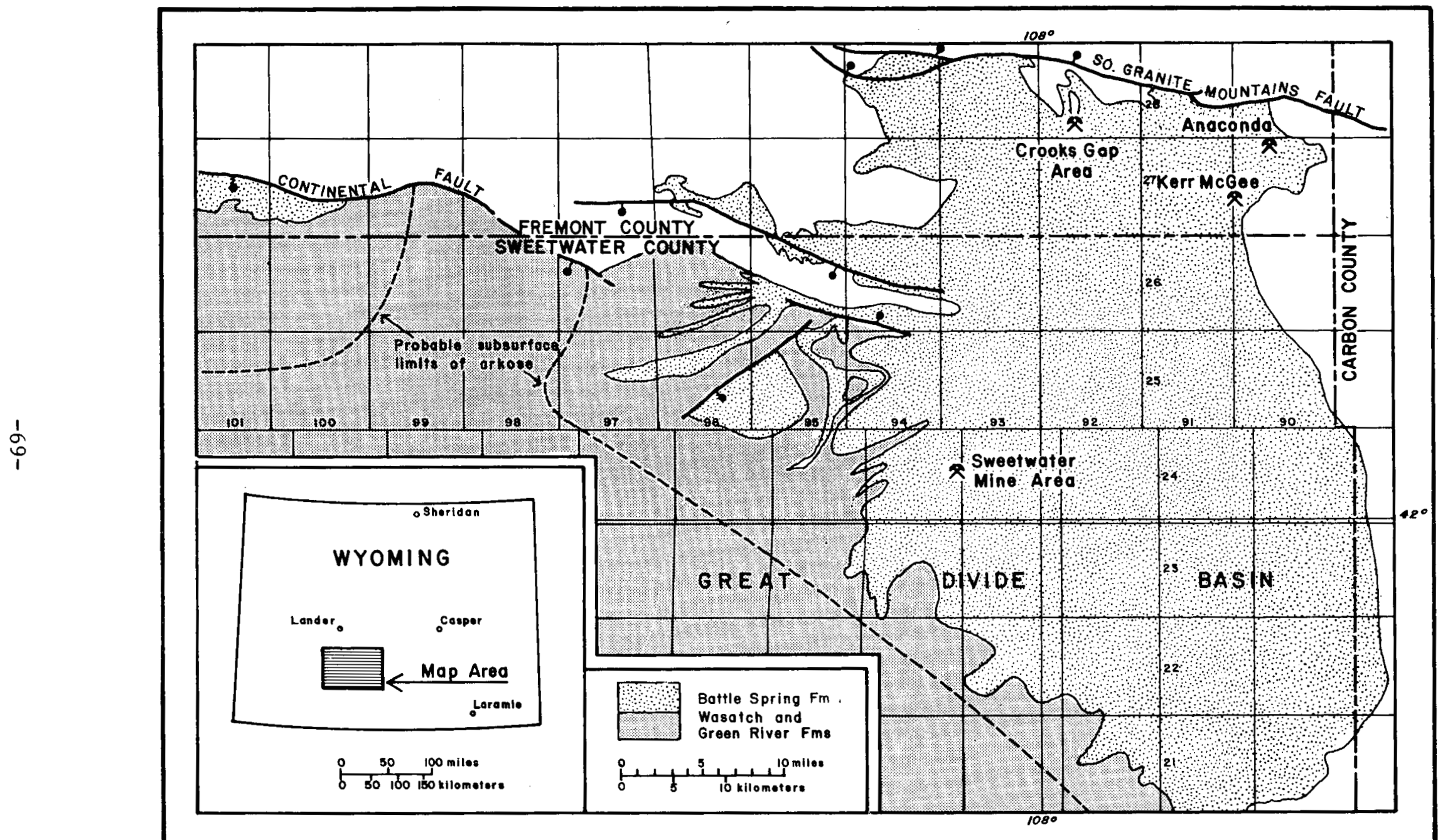

Figure 22. Generalized geologic map of Great Divide Basin, Wyoming, showing distribution of the Battle Spring, Wasatch and Green River Formations (modified from Pipiringos and Denson, 1970). 
As for the deposits in this area, Sherborne et a1 (1980) note that most of the known ore in the Sweetwater mine area (Fig. 22) is found in two extensive sandstone units 60 to 150 feet thick, each overlain and underlain by relatively thin mudstones that pinch out toward the margins of the basin (northward). Southward, toward the center of the basin, the mudstones grade into the uraniferous lignites described by Masursky (1962). Two thinner and less extensive sandstones underlie the principal ore-bearing sandstones. They also are bounded top and bottom by thin mudstones. Some ore has been found in these two lower sandstones, but the deposits are of minor economic importance and poorly explored; they will not be discussed in this report. The two upper sandstone units are described by Sherborne et al as consisting of "complexly interlensed sandstone bodies that range from less than three feet to greater than sixty feet thick." Individual lenses are characterized by

crude fining-upward sequences, commonly grading up from coarse pebbly sandstones near the base of channel scours to discontinuous sandy siltstone near the top. These units are characterized by local pebbly lags, planar foreset beds, and ripple drift cross-laminations. Larger channels contain festoon and planar cross-stratification, slump structures, and rare rip-up clasts.

Carbonaceous material consists of fragments of limbs, stems, and leaves of deciduous plants as well as reeds and ferns.

Orebodies in the Crooks Gap-Great Divide Basin are genetically related to tabular bodies or tongues of altered conglomerate and sandstone extending from the northern edge of the basin southward toward its center. In the Crooks Gap area alteration occurs in the lower 1500 feet of the Battle Spring Formation (Stephens, 1964), a thickness considerably greater than that in the Shirley Basin, Gas Hills, or Powder River Basin. The Crooks Gap altered sandstone tongue is complex and sinuous in plan as well as in section, and it terminates in a series of small, irregular, sinuous, roll fronts that are difficult to project beyond such workings. The irregularities in the edges of the tongue are due to the rapid changes in permeabilities of the host rocks, for in the Crooks Gap area rapid changes in lithology are much more common than in the host rocks of other uranium basins.

The Crooks Gap altered tongue has not been well defined because of its extreme irregularities, but altered sandstone has been recognized over a length of at least four miles and a width of almost two miles. There are few data available on the factors that controlled the position of the altered sandstone tongue, but it seems probable that alteration is limited more or less to those permeable sandstones and conglomerates deposited along with considerable carbonaceous debris in the channel of one of the major streams flowing from the Granite Mountains south into the Great Divide Basin (Childers, M. 0., oral communication, 1980).

According to Bailey (1969), the altered sandstone is characterized by shades of "pink, to pinkj.sh-red, to pinkish-brown" in surface exposures. This contrasts with normal shades of "drab white and tan" in surface exposures of unaltered Battle Spring. Where unaffected by surface oxidation, the contrast 
is between a "bleached whitish color" and the normal light-gray of unaltered and unmineralized sandstone. This bleached alteration is similar to that in the Gas Hills and is difficult to recognize in weathered outcrop.

In addition to color changes in the sandstone, the passage of groundwater produced a number of chemical and mineralogical changes in the host rock that here, as well as in the other Wyoming basins, generally can be classed as oxidative in character. Visual examination of mine workings uneffected by surface oxidation, and studies of samples taken by Bailey (1969) and Files (1970) show that the altered tongue is depleted in organic carbon, gypsum, calcite, pyrite, $\mathrm{SO}_{4}, \mathrm{Ca}$, total $\mathrm{Fe}, \mathrm{MgO}, \mathrm{TiO}_{2}, \mathrm{~S}$, and $\mathrm{H}_{2} \mathrm{O}$. The amounts of selenium, marcasite, and perhaps uranium are greater in altered than in unaltered sandstone.

The uranium deposits in the Crooks Gap area lie at the edge of the poorly defined altered tongue previously described. The orebodies are similar in most ways to those in the Gas Hills and Shirley Basin. They are of modest size, extending outward from the altered tongue for distances of a few to a few tens of feet. Ore contains from a few hundredths to as much as 10 percent $U$ and the highest grade ore may or may not be at the roll front. The ore minerals are uraninite, pyrite, native selenium, marcasite, and jordisite. Most of the ore is found in sandstone where the ore minerals fill open spaces in the rock, coat sand grains and partly replace feldspar. Some ore is found in coarse conglomerate where it coats pebbles and boulders, as well as in fine-grained siltstone and mudstone where it is associated with and partly replaces carbonaceous material.

The Crooks Gap orebodies differ from those in other basins only in their lack of continuity. In most other basins the roll fronts have considerable lateral and vertical continuity and ore, or at least mineralization, extends continuously along the front for hundreds or even thousands of feet. Not so at Crooks Gap, for although ore occurs adjacent to altered sandstone, it has proved almost impossible to project roll fronts or ore for more than a few tens of feet from their known positions (Bailey, 1969). The extreme irregularity of the interface between altered and mineralized sandstone as well as the poor continuity of ore undoubtedly relates to the great range of lithologies and permeabilities in the host rock.

Uranium deposits in the central part of the Great Divide Basin have been described by Sherborne et al (1980), whose report on the Sweetwater mine area presents considerable previously unavailable data. Mineralization in the Sweetwater Mine area (Fig. 22) is spatially and genetically related to altered tongues in four separate sandstone units found within a stratigraphic interval of about 600 feet. From top to bottom these are known as the ENQ, SweetwaterREB, $A-1$, and $A-3$ sandstones (Fig. 23). The mudstones that separate these four sandstone units thin and pinch out toward the margins of the basin and the four altered sandstone tongues probably merge into one thick tongue. The altered tongue in the Sweetwater-REB sandstone projects southward toward the center of the basin. It has a known length of about six miles, a width of from five to seven miles, and a thickness of from 150 to 160 feet (Fig. 23). On the eastern edge, near the Sweetwater deposit, the tongue contains a few thin lenses of gray-green siltstone or sandy claystone distributed through the predominantly sandstone host (Fig. 24). On the western edge, near the REB 


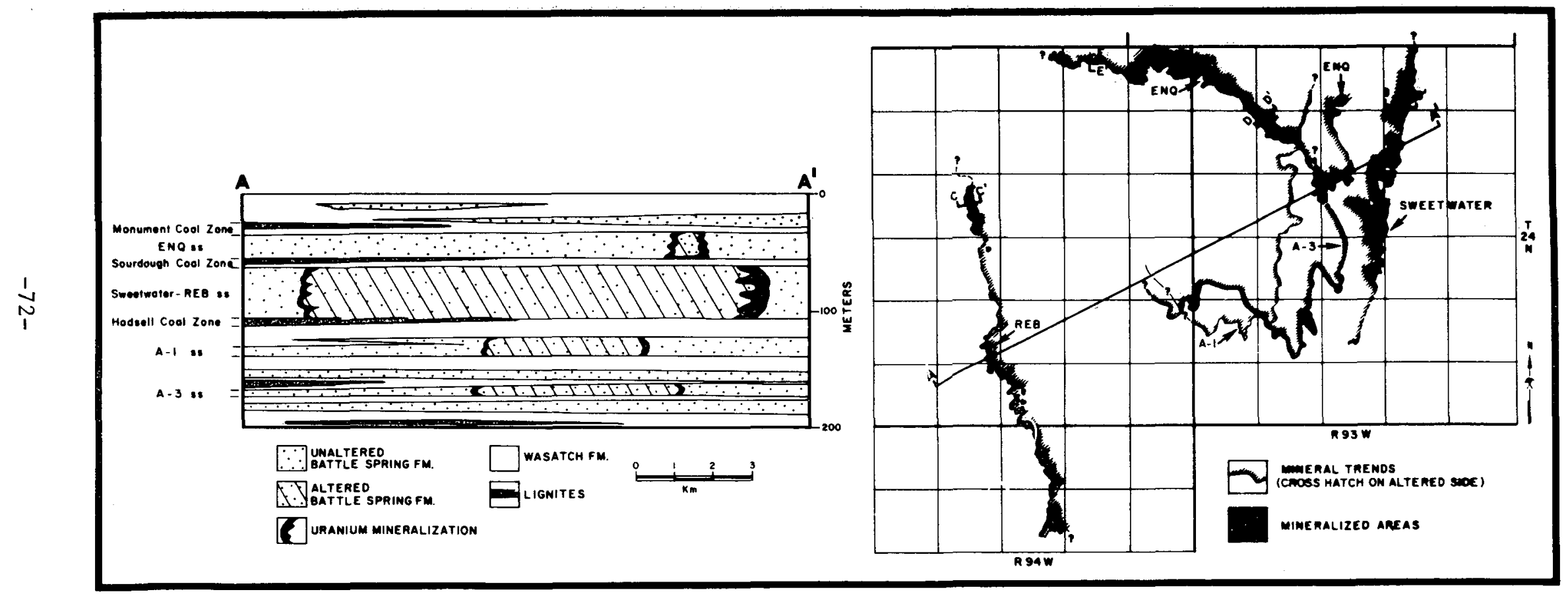

Figure 23. Generalized map and cross section of Sweetwater Mine area, Great Divide Basin, Wyoming, showing trend and relative positions of altered-sandstone tongues and the associated mineralized deposits (from Sherborne et al, 1980). 


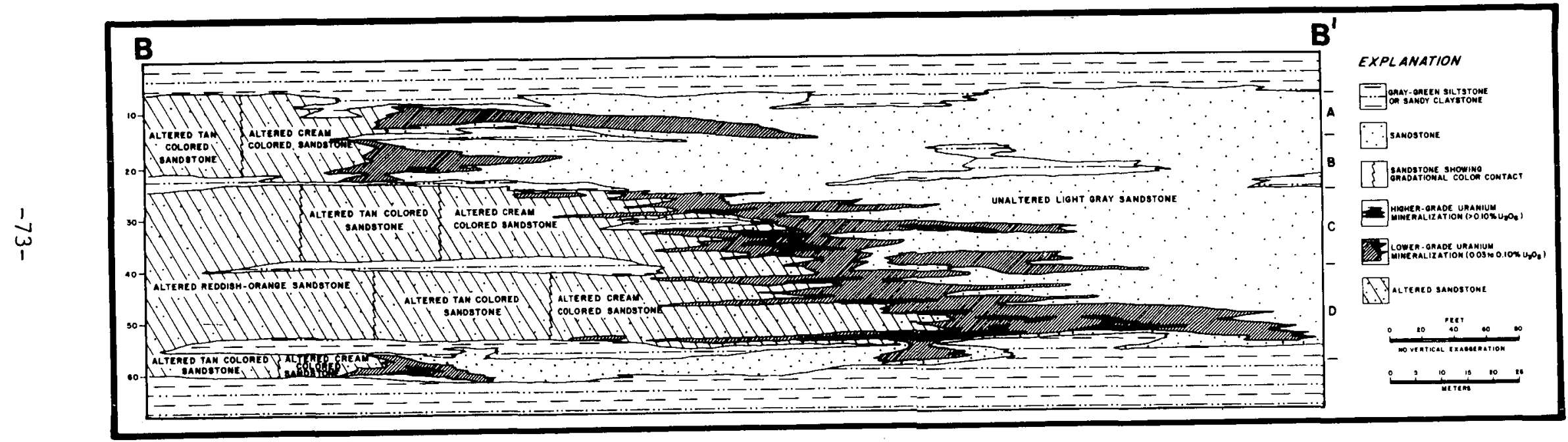

Figure 24. Cross section (B-B' Figure 23) through Sweetwater uranium deposit: Great Divide Basin, Wyoming (modified from Sherborne et al, 1980). 
deposit, the tongue contains a number of laterally continuous carbonaceous mudstones and poorly-sorted siltstones which divide the tongue into five separate sandstone beds all of which are altered (Fig. 25).

The predominant color of altered sandstone in the Sweetwater-REB and ENQ tongues is reddish-orange to orange and it contrasts noticeably with the light-gray color of the normal unaltered sandstone. Visual inspection of core and chemical and mineralogical analyses on a limited number of samples of altered and unaltered sandstone (DeNault, in press) show that carbonaceous material and pyrite, normally present in small amounts in the host rocks, have been completely destroyed in the altered sandstone. Also destroyed by alteration are hornblende, magnetite, and zircon. Ilmenite has altered to anatase and pyrite to goethite and hematite. Near the edges of both tongues there are changes in the character of the alteration that appear to be related to the width and grade of the mineralized sandstone adjacent to tongue's edge. These changes will be described in the following discussion of the principal deposits in the Sweetwater-REB and ENQ sandstones.

The Sweetwater deposit is located along the eastern edge of the Sweetwater-REB tongue. In this area the normal reddish-orange color of altered sandstone gradually gives way to tan and then to cream-colored sandstone (Fig. 24). The decrease in the intensity of coloration is due to a decrease in the amount of hematite, goethite, and smectite that coat the grains of the altered sandstone. The color changes near the edge of the tongue may take place over distances of several thousand feet, in which case the deposits adjacent to the tongue are wide and low-grade, or they may occur over distances of a few tens of feet, in which case the deposits tend to be more narrow and of higher grade.

In the Sweetwater Mine area, the host sandstone can be broken into four sandy intervals separated by thin lenticular mudstones. Most of the ore is associated with the two lower sandstone intervals for they are the thickest and laterally the most persistent. Mineralization persists for about four miles along the edge of the tongue and extends outward from it into the unaltered sandstone for from 1000 to as much as 2500 feet. Thickness of mineralization generally ranges from 6 to 16 feet, but may be as much as 65 feet where several sandy intervals merge to form stacked deposits. Most of the minera1ized sandstone contains about 0.05 percent or less $\mathrm{U}_{3} \mathrm{O}_{8}$, but some contains 0.10 percent or more. The average grade of the estimated 16 million metric tons of mineralized sandstone in the deposit is 0.046 percent $\mathrm{U}_{3} \mathrm{O}_{8}$.

There is considerable disequilibrium between uranium and its daughter products in the Sweetwater deposit. Where mineralization is above the present water table and the ore consists of yellow uranium minerals, uranium may be less or greater in amount than indicated by the gamma-ray activity of the daughters $(\mathrm{cU} \lessgtr e U)$. Most of the Sweetwater deposit is below the water table and overal1 the amount of uranium slightly exceeds that indicated by the gamma-ray activity of the daughters ( $\mathrm{cU}>\mathrm{eU}$ ) although the degree of disequilibrium ranges widely.

The REB deposit is adjacent to the western edge of the Sweetwater-REB altered tongue (Fig. 25). According to Sherborne et al (1980), this edge is "typified by a zoned pattern of iron-oxide staining and orange feldspar coloration." 


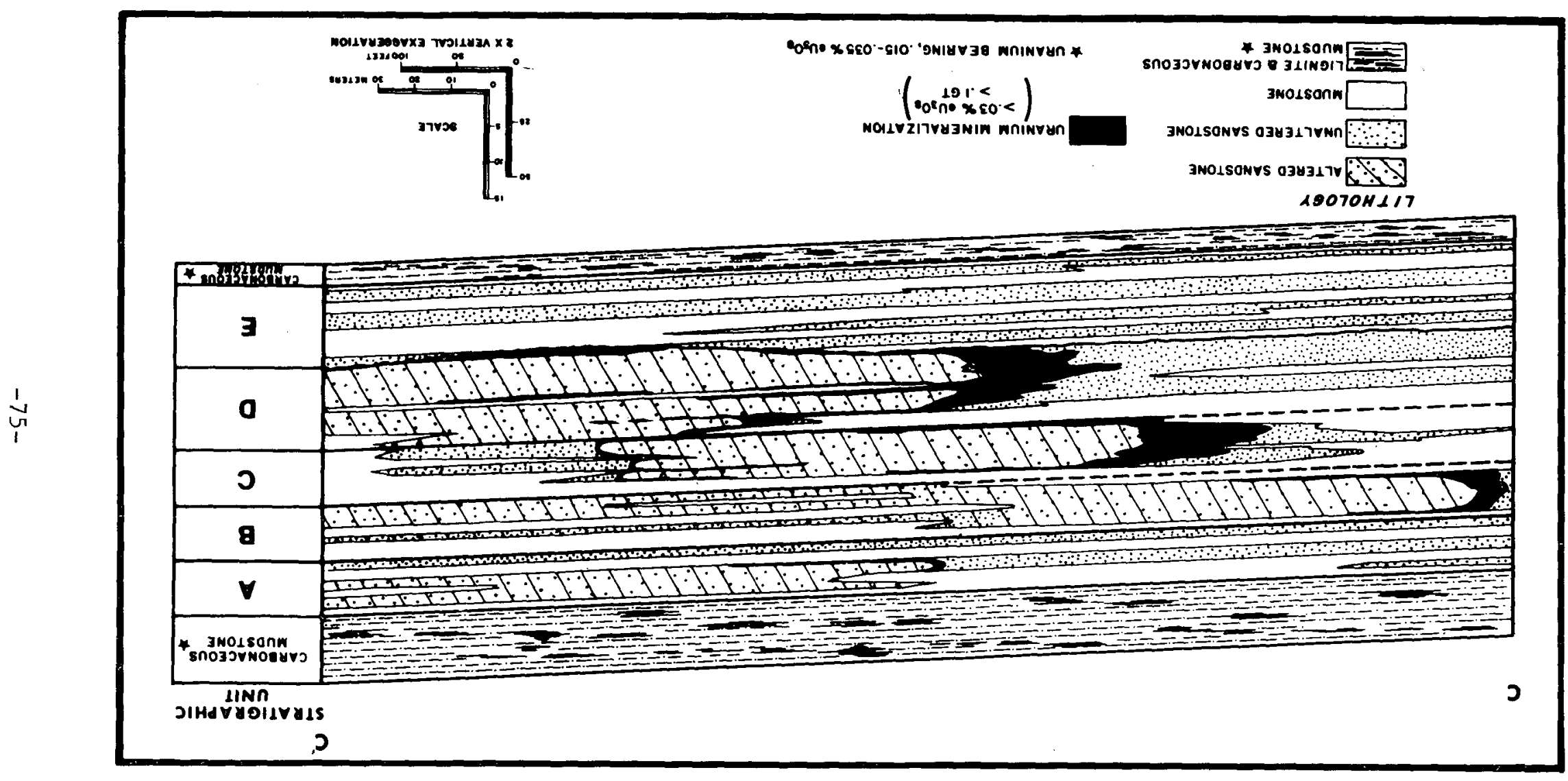

Figure 25. Cross section (C-C' Figure 23) through REB uranium deposit, Great Divide Basin, Wyoming (modified from Sherborne et al, 1980). 
The intensity of the iron oxidation, presumed to be hematite but not identified by the authors, is most intense several hundred feet from the tongue's edge and gradually diminishes toward the edge. Closer to the edge is a second zone of alteration which is characterized by 1ight-gray sandstones, almost indistinguishable from unaltered sandstone, and by oxidized mottled interbedded siltstone. A third zone of alteration, generally less than 300 feet from the tongue's edge, is characterized by orange-colored feldspars. The orange color increases as the edge of the tongue is approached and is most intense. near areas of highest grade mineralization.

In the vicinity of the REB deposit (Fig. 23) the Sweetwater-REB sandstone is about 165 feet thick and is broken into five tabular or lenticular sandstone units separated by laterally continuous carbonaceous mudstones and poorly sorted siltstones. In this area the sandstone units are thinner, and the mudstones are more carbonaceous and more extensive than similar rocks on the east side of the altered tongue near the Sweetwater deposit.

The REB deposit is about 5.5 miles long and extends from less than 50 to as much as 1000 feet outward from the altered sandstone tongue into the unaltered sandstone. Most of the mineralization is in the coarse-grained, thick, laterally continuous sandstones (units C and D, Fig. 25) where mineralized intercepts commonly range from 3 to 15 feet but may be as much as 35 feet. In the $\mathrm{D}$ unit, mineralization is nearly continuous along the 5.5 mile REB trend; in other units it is less continuous. The mineralized bodies are typically "C"-shaped and their average grade is nearly twice that of the Sweetwater deposit. There is a very narrow transition zone between well-mineralized and barren sandstone. The wide bodies of poorly mineralized sandstone characteristic of the Sweetwater deposit, and some areas in the Powder River Basin, are not present in the REB deposit. Characteristics of the REB deposit; the host sandstone, and the altered sandstone tongue are shown in Figure 25.

The ENQ deposit is in a 65-foot thick, coarse-grained, tabular sandstone unit that is bounded above and below by laterally continuous mudstones (Fig. 26). This unit overlies the Sweetwater-REB unit and is the host for a large tongue of altered sandstone projecting southeasterly into the Great Divide Basin (Fig. 23). The altered tongue has a known length of five miles and a known width of one mile, although additional exploration will probably show it to be much wider. The tongue lies above the eastern part of the Sweetwater-REB altered tongue, but it does not extend as far south (basinward) as does the Sweetwater-REB tongue.

Alteration in the ENQ tongue is characterized by iron-oxide coloration similar to that in the western part of the Sweetwater-REB tongue. Near the southeast end of the tongue the altered sandstone is yellow-gray to yellow-gray-green; unaltered sandstone is gray to gray-green. To the northwest, along the edge of the tongue, a zone of very subtle alteration, as much as 1,000 feet wide, with coloration indistinguishable from unaltered sandstone, separates the normal yellowish alteration from the mineralization at the edge of the tongue. Where this zone of subtle alteration is present, mineralized sandstone adjacent to the roll front contains yellow and pink, iron-stained quartz and feldspar grains. Mineralization seems to be highest grade where the zone of subtle alteration is widest. 
Mineralization is generally found in the lower part of the ENQ sandstone where there are few lenticular mudstones. It is higher grade but narrower in the northwestern part of the deposit than in the southeastern part or in the adjacent but underlyins Sweetwater deposit. In addition to well-developed roll-type mineralization, there is well-developed mineralization on both the upper and lower limbs of the roll. Widths of mineralized sandstone, including that on the limbs, ranges from about 100 to 1600 feet. Thicknesses are as much as 30 to 40 feet. A halo of low-grade mineralization, as much as 1000 feet wide in the southeastern and 20 feet in the northwestern part of the deposit, extends outward from the higher grade roll-type ore (Fig. 27). The character of the ENQ deposits, the associated altered sandstone tongue and the host sandstone is shown on Figures 26 and 27.

Sherborne et al (1980) have related the positions of the altered sandstone tongues and genetically related uranium deposits to the basinward pinchout of the permeable Battle Spring Formation and the isolation of ground water flow within a few aquifers in the Battle Spring Formation. In the Sweetwater Mine area, a few thick tabular sandstones, such as the Sweetwater-REB and ENQ intervals, served as the major laterally continuous aquifers in a thick section of intertonguing Battle Spring, Wasatch, and Green River sediments. The mineralizing solutions, which only a few miles north had been dispersed throughout a thick section of highly permeable Battle Spring Formation sandstones, were funnelled into these tabular units, where tabular, low-grade, large-tonnage deposits, as well as higher grade typical "C"-shaped, moderate tonnage deposits were formed at the edges of altered sandstone tongues.

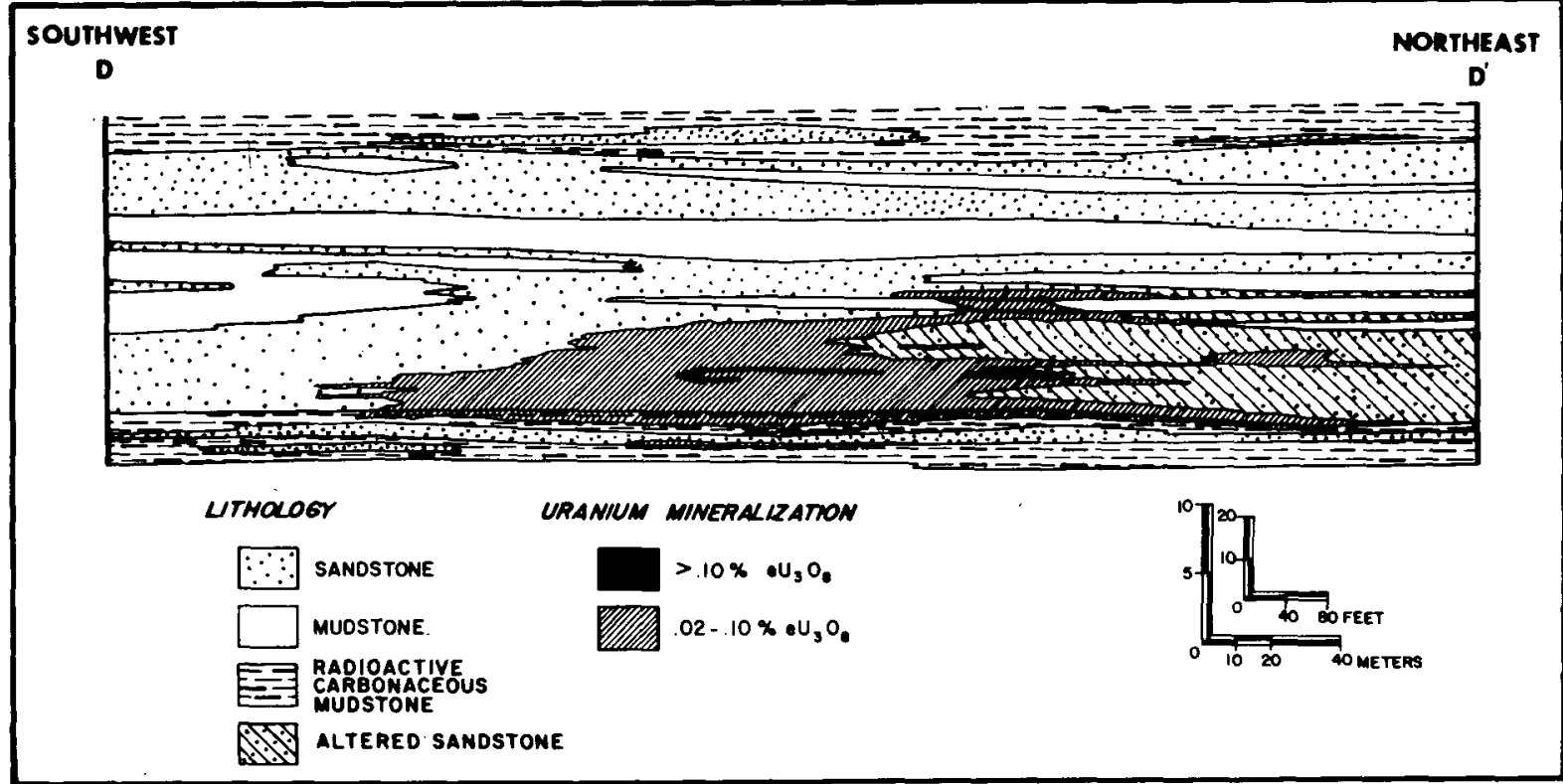

Figure 26. Cross section (D-D' Figure 23) through eastern part of ENQ uranium deposit, Great Divide Basin, Wyoming (modified from Sherborne et a1, 1980). 


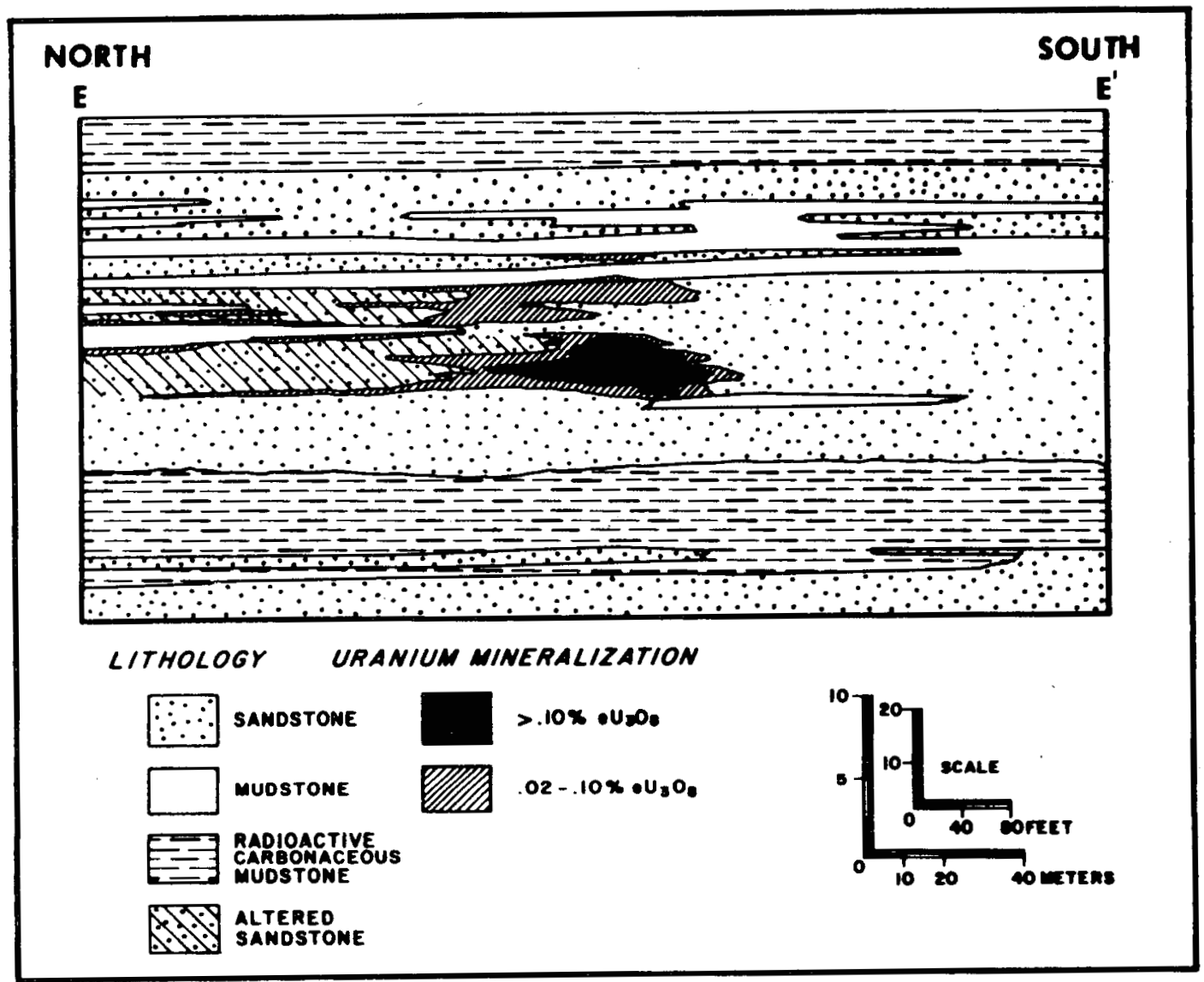

Figure 27. Cross section (E-E' Figure 23) through the western part of the ENQ uranium deposit, Great Divide Basin, Wyoming (modified from Sherborne et al, 1980).

Black Hills Area

Selected references: Vickers, 1957; Waagé, 1959; Brobst, 1961; Cuppels, 1963; Gott and Schnab1e, 1963; Robinson et a1, 1964; Hart, 1968; Renfro, 1969; Gott et al, 1974 .

The Black Hills are a broad domal uplift of Laramide age. The domal area lies in western South Dakota and northeastern Wyoming and is about 150 miles long and 50 miles wide (Fig. 1). Erosion has exposed the Precambrian granitic and metamorphic core of the uplift and truncated the outwardly dipping Paleozoic and Mesozoic rocks that surround the core. The Lower Cretaceous Inyan Kara group, the host for the Black Hills uranium deposits, crops out in a bold inward-facing hogback of sandstones that is the outermost geomorphic expression of the Black Hills structure. 
The Black Hills uranium deposits are in a belt of Inyan Kara rocks extending for about 125 miles along the west flank of the Black Hills. Minable uranium deposits, containing from a few hundredths to more than 1.0 percent $\mathrm{U}_{3} \mathrm{O}_{8}$ have been found in the three principal areas shown on Figure 28. Uranium is found in all sandstone facies of the Inyan Kara sediments (informally named from bottom to top, $S-1$ to $S-6$ ). The best deposits are generally found in units $S-$ $1, \mathrm{~S}-4$, and S-5, which are all fluvial, coarse-grained, channel sandstones as much as 250 feet thick, of considerable lateral extent, and undoubtedly good aquifers.

The Black Hills deposits are found at the distal edge of tongues of altered sandstone that extend downdip from the outcrop of the enclosing sandstone. In the larger more permeable channel sandstones, the roll fronts extend laterally for several miles along the strike of the sandstone beds; the entire length of the roll front may not be mineralized. In sandy intervals where the beds are discontinuous and interbedded with considerable mudstone, the altered tongues are generally small, irregular, and poorly mineralized. The complexity of the sediments in the Inyan Kara group has adversely affected the regularity, in both plan and section of the roll fronts, and the size and mineral content of the ore associated with them.

Hart (1968) concludes that positions of the three mining areas in the Black Hills area, and the altered tongues along which ore was deposited, were governed by movement of ground water toward the three principal streams that denuded the sedimentary succession and produced the present topography. Juxtaposition of the Cheyenne, Belle Fouche, and Little Missouri Rivers and the Edgemont, Carlile, and Hulett districts (Fig. 28) is the only evidence given as justification for this conclusion. The character of the sandstones in the three areas and lateral changes in permeability may have had an equal or greater influence on the districts' locations.

Mining and exploration in the southern part of the Black Hills area has made considerable data available on the character of the host sandstones, the character of alteration, and mineralogy of the ore. Discussions that follow are based largely on these data.

In the Edgemont-Dewey area, the host rocks are coarse-grained, permeable, channel sandstones of considerable lateral continuity and bounded top and bottom by impermeable mudstones. The sandstones are composed mostly of quartz and chert grains, although a few percent of microcline and albite are present. Kaolin constitutes a few percent of the coarse-grained sandstone, somewhat more is present in the finer-grained rocks. Kaolin coats sand grains and fills interstices in the sandstone. Calcite may be locally abundant but generally it is rare. When ore is present it fills voids in the sandstone and replaces quartz. The unaltered sandstone contains pyrite as small rod-1ike aggregates replacing carbonaceous material, or interstitially to sand grains. Carbonaceous vegetal material and humate is abundant in some sandstones, less in others. Associated fine-grained sediments are almost always carbonaceous. Heavy minerals, excluding pyrite, constitute about one percent or less of the rock--considerably lower than in arkoses derived from granitic terrains. Magnetite is present in some but not all heavy mineral suites. 


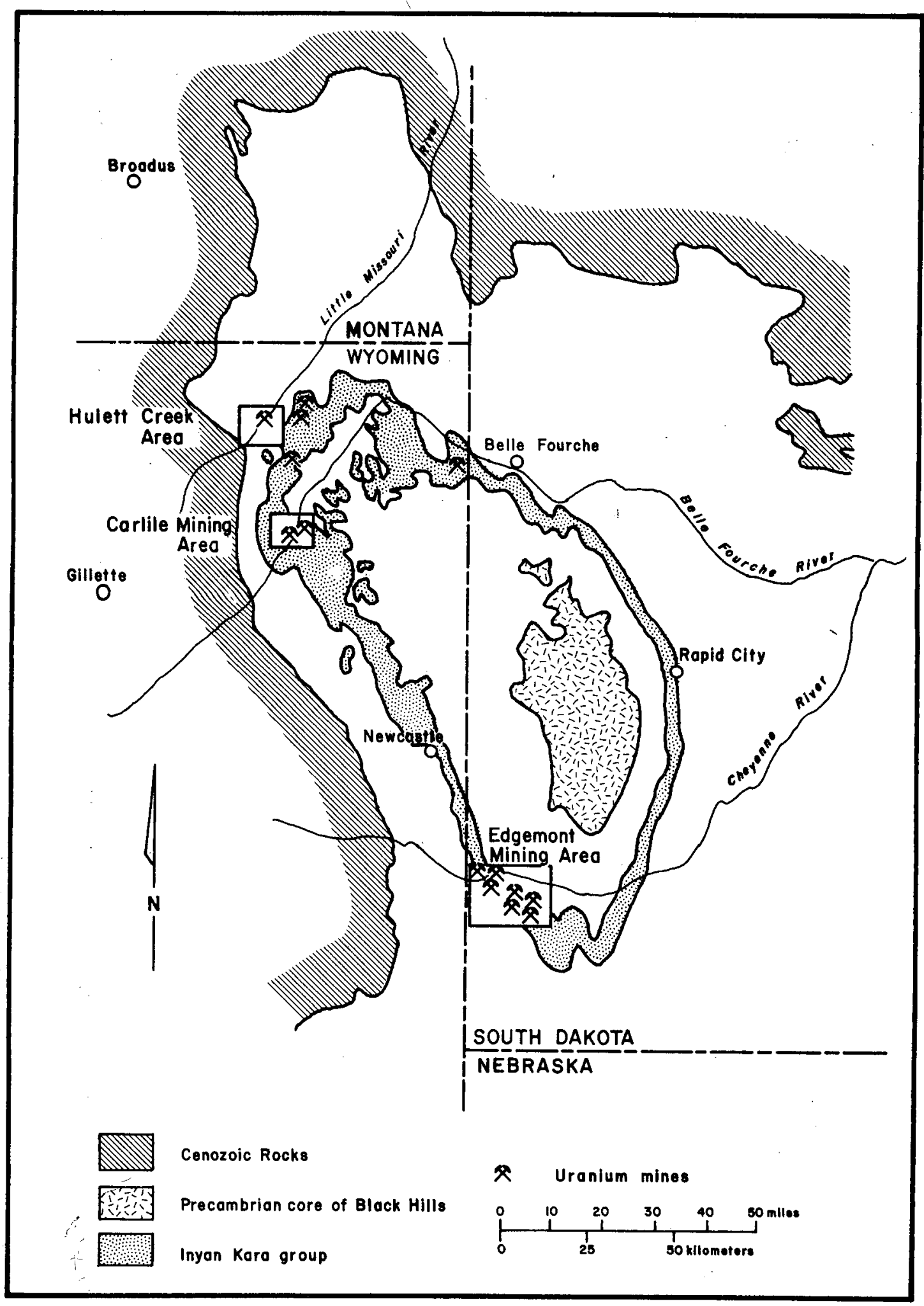

Figure 28. Generalized geologic map of the Black Hills Region, Wyoming and South Dakota (modified from Renfro, 1969). 
The structures of the west flank of the Black Hills are principally two monoclines separated by a structural terrace. The rocks to the east of the terrace have dips of 2 to 10 degrees westerly, while to the west of the terrace dips steepen to 10 to 25 degrees westerly. Most of the ore deposits are in the terrace structure where dips generally range from 1 to 3 degrees westerly but in some areas dips reverse to a degree or more easterly. Superimposed on these gentle structures are other major and minor folds of diverse orientation. Faults are structurally less important than folds and generally have displacements of less than 100 feet. Northwesterly structures and steep dips are most common. The major structural features in the area are related to the Laramide tectonism responsible for the Black Hills uplift and are pre-ore; very minor structural features, probably due to solution of underlying anhydrite beds, are post-ore.

Ore deposits in the southern Black Hills are related to tongues of altered sandstone that extend downdip from the outcrop for distances of from a few thousand feet to a few miles. The stratigraphic complexities of the host sediments directly affect the complexities of the altered tongues as well as the size, shape, and grade of the orebodies. As a general rule, the margins of the tongues in the Black Hills are much more irregular than those in the Wyoming basins. Thicknesses of altered tongues range greatly in the Black Hills area, but may be as much as 30 feet; thicknesses of 5 to 15 feet are common.

Alteration in the Black Hills is similar in most ways to that in the Wyoming bașins. Comparisons with unaltered sand show that the amount of U, V, Se, $\mathrm{Fe}$, and $\mathrm{As}$, in the altered tongue has been increased and that the amount of $\mathrm{Fe}^{++}$(principally pyrite), organic $C$, mineral carbon, and perhaps $\mathrm{Cu}$ has been decreased. The destruction of pyrite, magnetite and organic carbon in the altered tongues is essentially complete. Pyrite has been oxidized to hematite and in some areas to hematite and goethite. Both minerals coat sand grains and occur as small masses pseudomorphic after pyrite. Hematite imparts a red or pinkish-red color to the altered sandstone, goethite a brownish-yellow color. In those deposits where goethite and hematite occur in the altered tongue, goethite is in zones a few feet wide at the edge of the tongue. It thus lies between the red hematite interior of the tongue and the roll front, much the same as shown in Figure 20 for the Powder River Basin deposits.

The Black Hills deposits are of a roll-type located at the edges and to a lesser extent along the top and bottom surfaces of tongues of altered sandstone. Deposits in channel sandstones with lateral extents measured in miles and with somewhat isotropic permeabilities may approach the ideal " $\mathrm{C}$ "-shape so often shown in illustrations of roll-type deposits (Fig. 20). The highest grade and most extensive mineralization is on the nose of the roll, but mineralization of economic interest may be found in the upper and lower cusps of the crescent-shaped ore roll extending backward (updip) for several hundred feet. Such deposits range in size from a few hundred to a few tens of thousands of tons of mineralized sandstone containing from a few hundredths to over 1.0 percent uranium. Thicknesses of mineralized sandstone may be as much as 30 feet but generally are 10 feet or less.

Many of the deposits reflect the inhomogeneity of the host sediments and their permeabilities. These deposits consist of small tabular or complex sinuous 
bodies, some interconnected some not, but all are adjacent to and in contact with altered sandstone.

The mineralization in the Black Hills differs from that in the Wyoming basins in that vanadium minerals are an important component. The vanadium content of the ore often equals or exceeds the uranium content; vanadium/uranium ratios common1y are about 1.5/1.0. Uraninite and coffinite are the principal uranium minerals in the unoxidized ore. Vanadium minerals include paramontroseite, haggite, montroseite, doloresite, and others. Additional minerals deposited at or downdip from the roll front are pyrite, native selenium, calcite, and jordisite. Uraninite and coffinite are fine-grained, intermixed, and most generally occur interstitially to the sand grains. The two minerals are intergrown with bladed aggregates of montroseite and frequently replace pyrite. Paramontroseite, haggite, and deloresite are all intimately associated with montroseite and since they occur in the oxidized sandstone at the roll front they probably are oxidation products of montroseite. Native selenium occurs as needle-1ike crystals adjacent to ore on the oxidized side of the roll front. Pyrite is of two generations, one is early, probably diagenetic, the other late and associated with ore deposition. The early pyrite is emplaced in the voids of the sandstone, is in fine-grained cubic crystals, and is frequently associated with organic material. The later pyrite is closely associated with the ore minerals, is coarse-grained to nodular, is intergrown with marcasite near the roll front, and frequently replaces quartz. Calcite completely fills the pore space in some deposits and has corroded and replaced some of the quartz grains. Calcite concretions are common at the outer limits of ore.

The paragenesis of the ore minerals in samples from the Runge Mine are given by Gott and Schnabel (1963) as follows: calcite, pyrite, pyrite-marcasite, first stage uraninite, montroseite-haggite, second stage uraninite. Jordisite's place in the paragenetic sequence is unknown, but spatially it lies toward the unaltered sandstone edge of the ore, hence was probably precipitated last from a unit of solution.

Other Districts

Roll-type uranium deposits are found in areas other than those discussed in detail in this report. Available data on these less developed deposits suggest that they are similar in most ways to deposits in the older and better known districts. A brief description of some of the deposits of lesser importance follows.

\section{We1d County, Co1orado}

Selected references: Childers, 1974; Reade, 1976.

Ore deposits in Weld County, northwestern Colorado (Fig. 4), occur in sandstones of the Fox Hills and Laramie Formations of Late Cretaceous age (Reade, 1976). The Fox Hills host rocks are medium- to fine-grained sandstones, conglomeratic in some places, quartzose to feldspathic, micaceous, and carbonaceous. Marine fossils are present in some of the sandstones. The Fox 
Hills Formation is transitional upward from marine to continental conditions of sedimentation. The overlying Laramie (or Lance) Formation host rocks are medium- to fine-grained arkoses containing considerable pyrite and carbonaceous debris. Host sandstones range from a few feet to as much as 100 feet in thickness. Dips in the western part of the area are as much as 5 degrees eastward, but flatten to 1 degree or less in the eastern part. The source of the sediment was to the west and the sediments were deposited under continental or marginal marine conditions by eastward flowing streams.

The deposits are related to tongues of altered sandstone extending downdip from the outcrop or paleo-outcrop. The ore rolls may be single and simple, single and complex, or multiple and stacked. The alteration in some areas is hematitic, in others limonitic. Ore and accessory minerals are uraninite, coffinite, pyrite and marcasite. Vanadium content is low and molybdenum is apparently absent. The deposits contain from a few thousand pounds to as much as several million pounds of $\mathrm{U}_{3} \mathrm{O}_{8}$ in sandstone averaging about 0.10 percent $\mathrm{U}_{3} \mathrm{O}_{8}$.

Childers (1974) relates the mineralization to an extensive erosional unconformity between the Laramie (Lance) Formation and the overlying Brule and Chadron Formations, the White River Formation equivalents in this area ${ }^{1}$. Figure 29 shows these relations for the Goshen Hole area which is 100 miles north of, but geologically similar to, the Weld County deposits. The Chadron

W

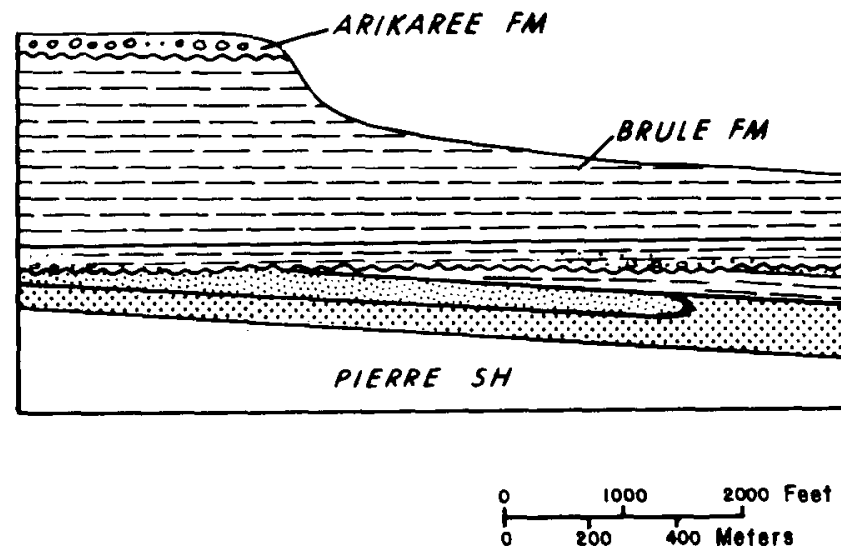

No Vertical Exoggeration

Figure 29. Cross section in Goshen Hole on the west flank of the Cheyenne Basin (modified from Childers, 1974).

\footnotetext{
${ }^{I}$ In Wyoming it is customary to use the term White River as a formation name recognizing that to the east the unit becomes a group divisible into the Chadron and Brule Formations.
} 
Formation rests on the beveled edges of the Laramie and in places there are conglomerate-filled channels of Chadron cut into the Laramie. There is alteration but no mineralization in the Lower Chadron channels, but where the altering solutions passed from the Chadron downdip into the reducing environment of the Laramie or Fox Hills sandstones, mineral deposits did form.

The source of the uranium was probably the tuffaceous material in the Chadron and Brule Formations (White River Formation) which overlies or once overlay the area. The age of the mineralization has not been determined, but it is reasonable to assume that mineralization was related to the same orogenic, climatological, and hydrologic factors that produced the deposits in the Wyoming basins and thus is Late Eocene to Middle or Late 011gocene. Some late modification of the deposits, and re-reduction of the altered oxidized sandstone may be related to the present hydrologic system.

\section{Kaycee Area, Wyoming}

Selected references: Childers, 1970, 1974.

The Kaycee area is on the west flank of the Powder River Basin about 70 miles north of Casper, Wyoming (Fig. 18): Rol1-type uranium deposits, related to large tongues of altered sandstone, have been found in the area. They are described by Childers (1970) from which much of the following description is taken.

The host for the Kaycee deposits is the Paleocene Fort Union Formation. It rests with slight angular discordance on the fluvial and lacustrine sandstones and shales of the Lance Formation of Late Cretaceous age and is overlain unconformably by the fluvial Wasatch Formation of early Eocene age. The Fort Union in the Kaycee area may be divided into three units: (1) a basal sandy unit about 1000 feet thick; (2) a middle gray shale and bentonitic unit 500 to 1000 feet thick; and (3) an upper sand and shale unit about 1000 feet thick. The thickest and laterally most extensive sandstones are in the basal sandy unit where individual sandstone beds are as much as 100 feet thick. The sandstones are crossbedded, contain clay galls and conglomerate lenses, and show other features of large high-energy streams. The principal stream draining the Wind River Basin may have flowed northeasterly through the Kaycee area and into the Powder River Basin in early Paleocene time. The upper sandy unit has an extensive 250-foot thick conglomeratic sandstone at the base, but other sandstones in the unit are lenticular and of limited lateral extent. The upper unit contains considerable silt, shale, mudstone, and carbonaceous material.

The sandstones in the overlying Wasatch Formation are similar to those in the upper part of the Fort Union. They are interbedded with many mudstones, some of which are red and green and contrast with the gray of the Fort Union mudstones.

The Kaycee area lies in a large broad syncline developed on the west flank of the Powder River Basin. The syncline plunges to the northeast and the Fort Union and Wasatch strata dip easterly at angles of 10 to 25 degrees. Childers (1970) believes that the beds were folded before the deposits were formed. 
The uranium deposits are related to large lobate tongues of altered Fort Union sandstone that can be traced on the surface for about 15 miles. There are some secondary uranium minerals in outcrops of altered sandstone where that sandstone contains considerable organic material. These small deposits are probably residual having been preserved in otherwise oxidized sandstone by local high organic concentrations in the sandstone. "The altered tongues are stained red by hematite coatings on the sand grains, generally contain ironrich calcite concretions, but contain little or no carbonaceous material or pyrite. This contrasts with the gray, pyritic, carbonaceous character of the unaltered sandstone. Childers reports "coarse aggregates of pyrite, heavily stained with humate" in some of the unaltered reduced sandstone.

The deposits are typical of those associated with redox interfaces in the Wyoming basins, lying at the edges of altered sand tongues, somewhat crescentic in shape, and composed of uraninite and/or coffinite, pyrite, and a vanadium mineral, probably montroseite. The high vanadium content (often several times that of uranium) of the Kaycee deposits shows a similarity with the Black Hills deposits, rather than with those in the Powder River Basin, Shirley Basin, and Gas Hills. The deposits are generally small having the thicknesses of 5 to 30 feet and extending 50 to 75 feet laterally from the redox interface. Grades range to as much as $]$. percent $\mathrm{U}_{3} \mathrm{O}_{8}$, but probably average about 0.15 percent.

The source of the uranium and vanadium in the deposits, and their age, is conjectural. The uranium may have come from the Wasatch arkoses short1y after they were deposited disconformably on the Fort Union or from the White River tuffaceous sediments short1y after they were deposited unconformably over the Wasatch. Although the White River is not now present in the area, it is almost certain that it was present and was subsequently removed by erosion.

\section{Lake Frome Area, South Australia}

Selected references: Callen, 1975; Haynes, 1975; Brunt, 1978.

Uranium deposits, probably of the roll-type, have been found in Lower Tertiary fluvial paleochannels in the Lake Frome area (Fig. 30) of South Australia (Brunt, 1978). Uranium occurs in the basal sands of two paleochannels separated by a buried structural high of granitic and metasedimentary rock. The channels are Paleocene or Eocene in age and were cut in Cretaceous marine clays, Cambrian shales, sands and limestones, and Precambrian igneous and metamorphic rocks. One channel (the Yarramba) has been defined by drilling for a length of about 25 miles and neither the headwaters nor the outlet has been determined (Fig. 31). The channel is sinuous, ranges from about 1 to 4 miles wide, and contains as much as 175 feet of channel fill. The top of the channel is represented by a Lower Tertiary-Upper Tertiary unconformity which lies at a depth of about 225 feet below the present ground surface.

The channel fill consists of three flat-lying sand units separated by two clay units, all of which onlap the banks cut into the underlying Cretaceous strata (Fig. 32). The lowest sand unit is a high-energy, braided stream deposit and the shape of the channel in which it was deposited was controlled by the basement geology. Upward, the sands represent progressively lower-energy stream deposits culminating in the meandering stream deposits of the upper sand. 


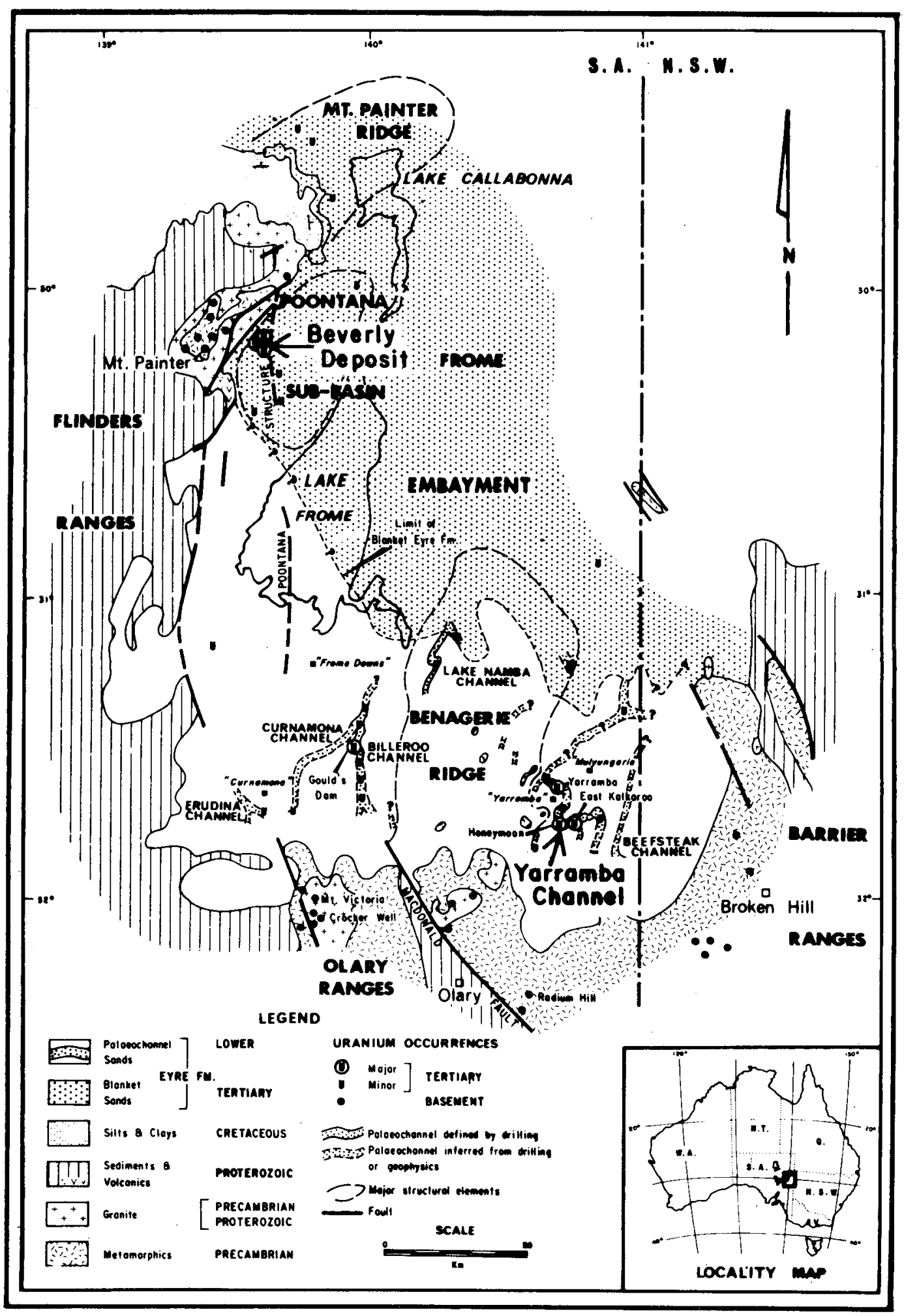

Figure 30. Uranium deposits and occurrences of the Frome Embayment and surrounding basement area, South Australia (modified from Brunt, 1978). 

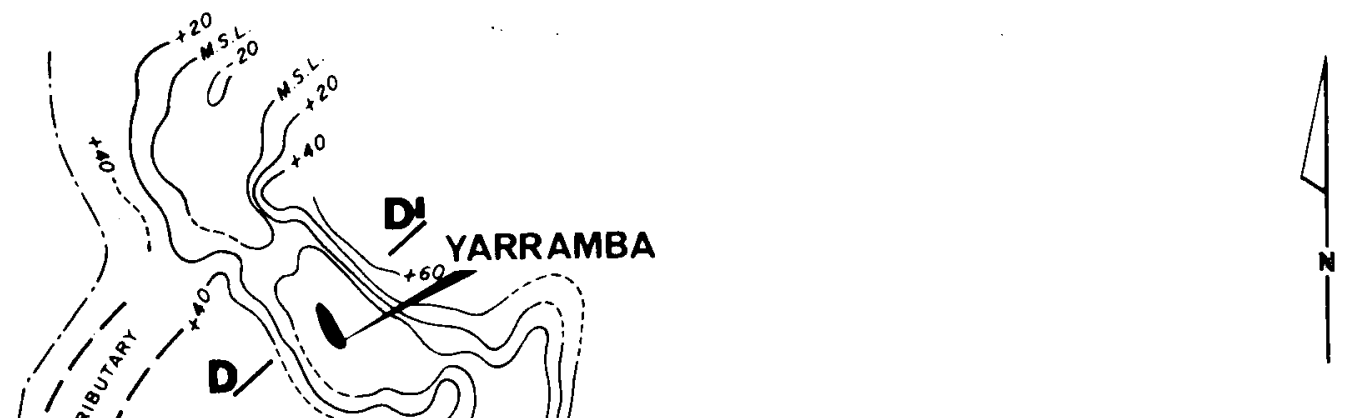

$1 / \frac{1}{1 / 2}$

D

- is

1

HONEYMOON
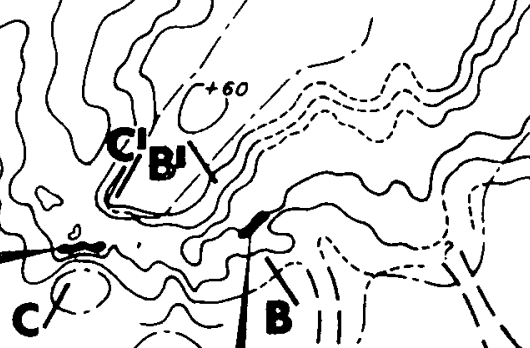

EAST KALKAROO
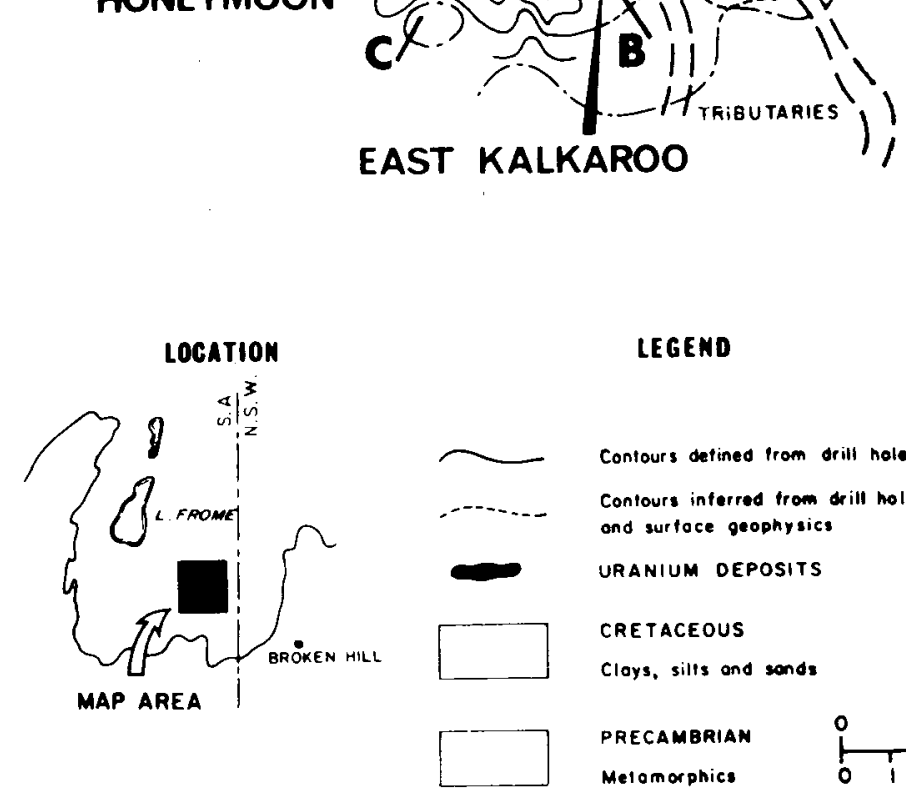

LEGEND

Confours detined trom drill holes

Contours inferred trom orill holes

and surtace geophysics

URANIUM DEPOSITS

CRE TACEOUS

Cloys, silfs and sonds

PRECAMBRIAN

Melomorphics
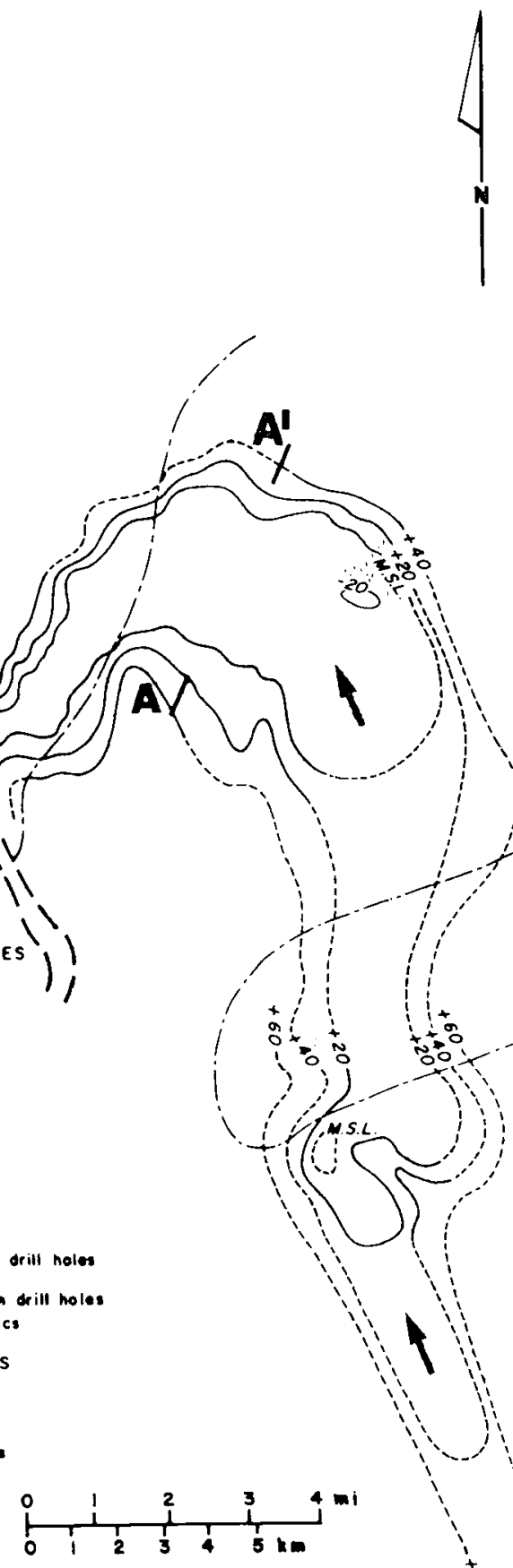
The channel contains pervasive anomalous radioactivity generally associated with thin intervals of clay and silt bounding the major sand units. The anomalous radioactivity has been determined to be due solely to uranium daughter products. Uranium mineralization is related to alteration in the sandstone, presumably produced by solutions moving northward down the slight dip of the channel. Unaltered sandstone is 1ight gray, pyritic, and carbonaceous. Altered sand is yellow or orange, limonitic and lacking in carbon. Altered sand generally extends to within a few hundred feet of the channel banks so that as much as 90 percent of the total volume of sand is oxidized. Where interbedded marginal clays are absent alteration may extend to the banks, occupying the entire channel fill.

Several deposits have been discovered in the Yarramba channel (Figs. 31 and 32). All are associated with a redox interface that extends more or less parallel to and a few hundred to a few thousand feet from the banks. Orebodies in one deposit average about 15 feet in thickness at an average grade, as interpreted from gamma-ray logs, of about 0.26 percent $\mathrm{U}_{3} \mathrm{O}_{8}$. In another deposit, mineralization is about 5 feet in thickness at an average grade of 0.20 percent $\mathrm{U}_{3} \mathrm{O}_{8}$. Orebodies may be as much as 1000 feet wide. Lower 1 imb ore is particularly well-developed and may constitute a significant part of the orebody. Ore minerals include coffinite and pyrite with some associated clayey humic material. There is little or no associated vanadium or molybdenum, although some copper and zinc are present in the ore.

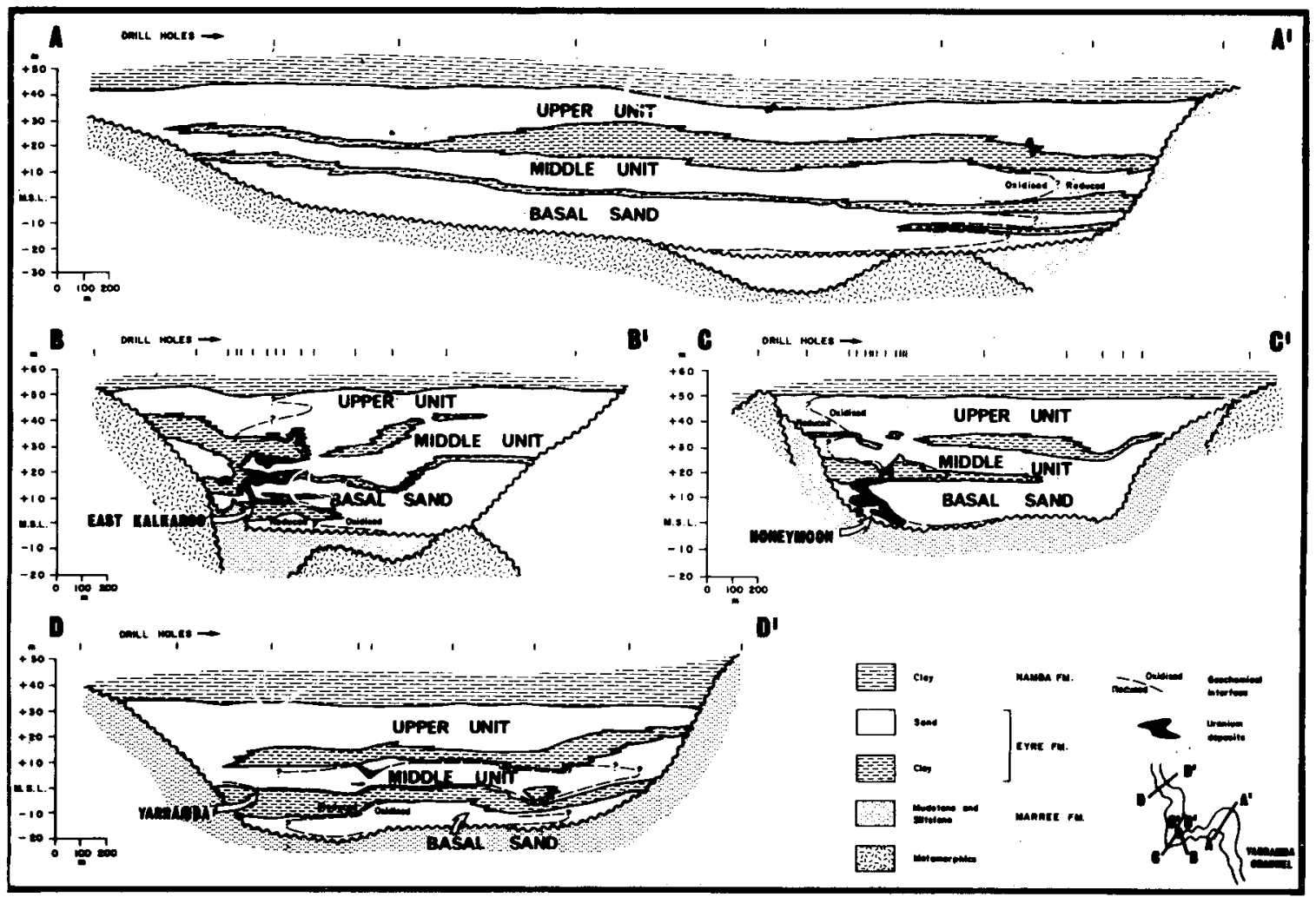

Figure 32. Cross sections across the Yarramba Channel, South Australia (from Brunt, 1978). Section locations are shown in Figure 31. 
These deposits are considered to be remnant deposits along the edges of a long narrow tongue of altered sand produced by oxygenated uranium-bearing water flowing down the gentle dip of the channel. Redox interfaces developed near the lateral margins of the channel where reduced permeability and sand thinning reduced ground water flow. Uranium was precipitated at points along this interface where pyrite and carbon content of the host rock was highest, generally near embayments in the stream banks. The oxidized altered host rock is depleted in uranium, suggesting that the host itself may have been the source of the uranium in the deposits.

The Beverley Deposit is located approximately 120 miles northwest of the Yarramba deposit (Fig. 30). The deposit occurs in sand lenses within fine argillaceous sediments of Miocene age. The host sediments lie unconformably on Cretaceous shales and sandstones. The tabular orebodies extend over a distance of 1.8 miles north-south and widths of 300 to 3000 feet. The ore lenses themselves occur within sands that are underlain by carbonaceous mudstones and overlain by non-carbonaceous clays (Fig. 33). The deposits are considered to be roll-type deposits (Haynes, 1975) and to occur at "an oxidation reduction interface". However,

- . features of the Wyoming deposits are missing, such as the barren interior, the plentiful coarse secondary and fine tertiary pyrite, the significant quantities of molybdenum, copper, vanadium, and thorium in the front, and coarse clastics that are the more usual hosts.

The genesis of this deposit is unclear, but the proximity of the tabular ore zones to the underlying carbonaceous shale is noteworthy and will be discussed later in this report. 


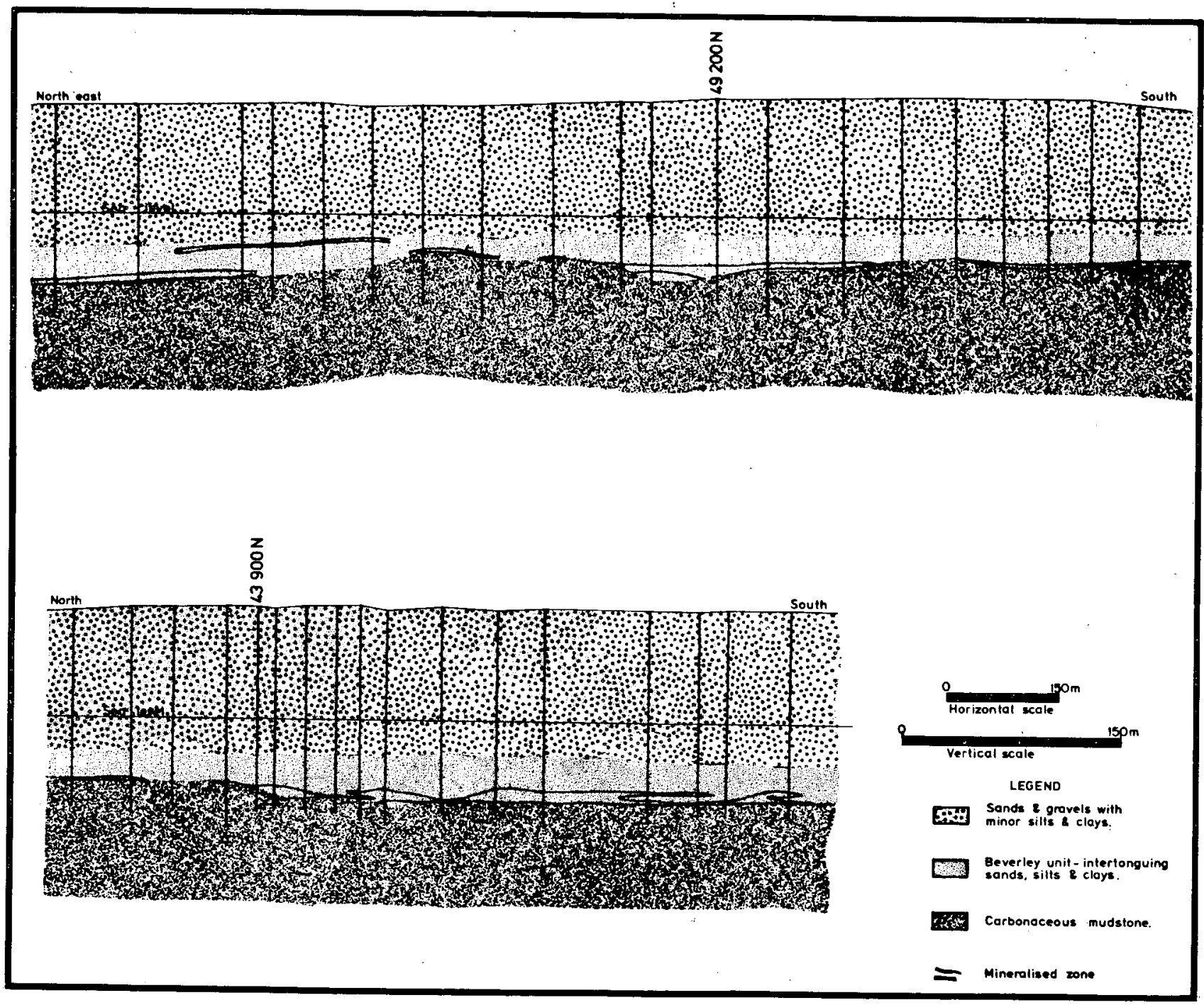

Figure 33. Longitudinal cross sections for the Tertiary Beverley uranium deposit, South Australia (from Haynes, 1975). 
Selected references: Gruner, 1956; Vickers, 1957; Jensen, 1958; Kashirtseva, 1964; Cheney and Jensen, 1966; King and Austin, 1966; Harshman, 1966, 1968, 1970, 1972, 1974; Lisitsyn and Kuznetsova, 1967; Adler and Sharp, 1967; Melin, 1969; Bailey, 1969; Davis, 1969; Granger and Warren, 1969; Fischer, 1970; Files, 1970; Gabelman, 1970; Warren, 1971, 1972; Rackley, 1972, 1976; Adler, 1974; Childers, 1974; Dooley et al, 1974; Dahl and Hagmier, 1976; Granger and Warren, 1978; Ludwig, 1978, 1979; Goldhaber and Reynolds, 1979; Bailey, 1980.

For purposes of resource studies and exploration the geologist requires geologic criteria or "guides" that (a) indicate the favorability for or proximity of deposits, and (b) can be applied in regional reconnaissance studies. The following considerations of ore formation and controls focus, therefore, on establishing the relations between geologic observations at that broad scale, particularly those discussed in the preceding section of this report. Investigations of genesis are a means of testing the relations between geologic observations and establishing confidence as to which empirical observations are truly important to ore formation and control. More specifically, which observations are always related to ore, which occasionally and under what conditions, and which are randomly or unsystematically related to rol1-type deposits. This discussion of ore formation does not, therefore, consider many of the detailed problems of solution chemistry, uranium mineral identity and stability, or the precise role of organic matter in ore formation. Rather, we attempt to reach reasonable conclusions on a scale of observation and level of detail that reflects both the objectives of this review and the data available.

Any acceptable theory of origin of roll-type uranium deposits must explain their restricted stratigraphic distribution, their spatial relation to large tongues of altered sandstone, and the systematic distribution of their component minerals. It must encompass the source of the uranium and associated elements, the nature and hydrodynamics of the mineralizing fluid, the geochemistry of mineral precipitation and the disposition of the spent mineralizing fluid. Reconstruction of processes that operated eons ago is of necessity speculative and interpretative. However, numerous prior studies on aspects of roll-type deposits have identified the general conditions of ore formation and sufficient data are available to help keep that speculation within reason while interpreting the important processes responsible for the deposits.

\section{Source of Uranium and Associated Elements}

The deposits are clearly epigenetic for mineralization cuts sharply across the depositional structures of the sandstone host rock. It is possible that some of the uranium in carbonaceous siltstones interbedded with the sandstones is syngenetic, but the amount of such uranium in any roll-type deposit is probably insignificant.

After about twenty-five years of study of roll-type uranium deposits in Wyoming, the source of uranium and other elements in the deposits is not known. 
Uranium is present in many geologic environments, is readily soluble in solutions similar in composition to present-day ground water, and can be easily precipitated by changes in $\mathrm{Eh}$ and $\mathrm{pH}$ of the transporting media. In the following paragraphs, possible sources will be examined and evaluated in light of present-day knowledge. " The least probable sources will be examined first.

Few, if any, geologists now propose a magmatic hydrothermal source, although this concept held favor for many years. Extensive mining and geologic study of orebodies in Wyoming and South Dakota have not found one bit of evidence either in the ore, the host rocks, or the alteration accompanying the ore, that suggests a direct magmatic source of elements in the deposits. Furthermore, there is no known period of magmatism that can be related in time or space to the deposits. In addition to the lack of evidence of a magmatic source, the spatial relations of the deposits to the distal parts of the tongues and the fact that many altered tongues extend updip to the present surface implies that the mineralizing solutions move downdip from high on the flanks of the basins. This is a movement compatible with a source of the elements and solutions above the deposits, probably at or close to the surface at the time of mineral deposition. Thus, a magmatic hydrothermal source is improbable.

A variation on the concept of a hydrothermal source has been proposed by Gabelman (1970). He concludes that,

Because compressive orogeny is mostly crustal, the mineralizing fluids it generates most logically and conveniently are connate or ground waters, or water of crystallization squeezed from the rocks. They gain increasing corrosive power to leach mobile elements from rocks as the rocks are heated by deformation. The fluids are mobilized by differential tectonic pressures as well as temperature. They enter the magmatic-hydrothermal cycle when compression reaches the anatectic stage. Without magmatism, they may be termed tectonic hydrothermal or simply hydrothermal fluids. The differential mobility of the various elements in response to rising temperature liberates elements in reverse paragenetic sequence and moves them forelandward down the metallotectonic temperature gradient to new zones of stability. Thus, the more mobile, lower temperature elements are flushed from hinterland regions.

The proof of this genetic theory is almost totally lacking. In an earlier development of the theory (Gabelman and Krusiewski, 1964), the authors justify their ideas by pointing out the position of the deposits in Wyoming parallel to and at some distance from the axes of the uplifts and on a purported metal zoning outward from the mountain cores. They do not accept the fact that the very forces that gave rise to the uplifts, set in motion a sequence of events that formed the basins adjacent to the uplifts, filled the basins with sediments receptive to subsequent mineralization, directed ground water flow through the favorable host rocks and exposed the granitic cores to weathering processes that may have contributed uranium and other elements to the ground water. The concept is not widely accepted and given the utter lack of corroborative data is likely to remain so.

Two other possible sources of the elements in the deposits are: (1) from fine-grained rocks lying downdip from or stratigraphically below the deposits 
(Vine and Tourtelot, 1970), and (2) from soluble anhydrite beds stratigraphically below the Inyan Kara host rocks in the Black Hills (Gott et a1, 1974). Since there are no lake beds associated with the Wind River in the Shirley Basin and Gas Hills, nor with the Battle Spring at Crooks Gap, and since the lake beds in the Wasatch are 50 miles or more downdip from the deposits at the south end of the Powder River Basin, a lake bed source for the elements in the deposits and transportation in pore water expelled on compaction cannot be, and has not been, seriously considered.

Gott et al (1974) propose that the source of the uranium and associated elements in the Black Hills deposits was in a sequence of sedimentary rocks, predominantly limestones but including sandstones, shales, and anhydrite. These rocks range in age from Devonian to Permian and lie 500 to about 2000 feet stratigraphically below the host Inyan Kara Formation. The authors admit the possibility of some contribution of uranium from granites or tuffaceous rocks via recharge of the older rocks by surface water. They theorize that the mineral elements were transferred upward by artesian recharge of the Inyan Kara by waters from the underlying rocks. There is some evidence of a presentday recharge of the type proposed, but no evidence for or against such a recharge at the time the deposits were formed. It is difficult to assess the validity of this model. It does not explain why the altered sandstone tongues often extend to the present outcrops of the host sandstone, suggesting surface or near surface introduction of the mineralizing solution, nor does it qualify as the simplest model that fits the facts--always a wise choice. If this model were correct, it would apply only to the Black Hills.

The host rock itself, particularly if it is an arkose, has been considered by some geologists (Melin, 1964; Rackley et al, 1968; Renfro, 1969; and others) to be the source of the elements in the deposits. However, there is reason to believe that the host rock itself may not be the source. The readily soluble uranium in the granitic rocks, from which the arkoses in the Wyoming basins were derived, would have been leached during the long period of oxidation, weathering, and disintegration in the uplands and subsequent transfer of this arkose into the basins. The quartzose host rocks in the Black Hills should have contained even less of the elements needed to form the deposits for they are second-cycle sediments whose mineral components have been through two cycles of weathering, disintegration, transportation, and deposition.

Analytical data on samples of altered and unaltered sandstones from the Shirley Basin (Harshman, 1972), the Powder River Basin (Davis, 1969), Crooks Gap (Bailey, 1969), and the Black Hills (Harshman, 1974), taken from a few to several thousand feet from ore, support the contention that the host rock is not the source of the elements in the deposits. The above investigators found from two to five times more selenium in altered than in unaltered sandstone. Samples from the Shirley and Powder River Basins showed the altered sandstone to contain from. $1-1 / 2$ to 10 times as much uranium as the unaltered sandstone. Renfro (1969) reports that unaltered sandstone contains less uranium (5 ppm) than does altered sandstone (14 ppm). The 14 ppm figure is about three times the amount of uranium in an "average" sandstone in the Wyoming districts and suggests that the samples Renfro considered unaltered were actually mineralized, and thus his conclusion that uranium had been removed during alteration may be open to question. One must conclude that uranium and selenium have 
been introduced into the sandstone from an outside source for a material balance shows an increase in the amount of uranium and selenium in the system after alteration and mineralization.

There is ample evidence that granites and tuffaceous rocks, the two sources most often cited as contributing uranium and other elements to roll-type deposits, can and are contributing these elements to present-day ground water. By extrapolation, these sources alone or combined could have and probably did furnish the bulk of the elements in the ore.

Samples of ground water issuing from springs near the base of the upper unit of the tuffaceous White River Formation in the Shirley Basin, waters that because of topography are isolated in that formation, contained from 8 to 10 parts per billion ( $\mathrm{ppb}$ ) uranium. Water from springs at the base of White River, in a more tuffaceous section, contained 19 to $52 \mathrm{ppb}$ uranium (Harshman, 1972). This is 2 to 10 times more uranium than was found in waters from the Wind River Formation in an unmineralized area west of the Shirley Basin. In addition, the water samples contained from a few to a few tens of parts per billion lead, manganese, zinc, nickel, vanadium, and selenium.

Recent investigations by Zielinski (1980) in the Shirley Basin show that chalcedony collected from and directly beneath accumulations of rhyolite ash in the White River Formation contain as much as $250 \mathrm{ppm}$ uranium. The uranium is distributed homogeneously through the silica, probably as a uranyl species. He postulates that uranium and silica were leached from the ash by downward percolating ground water and were precipitated as a uraniferous silica gel directly above the relatively impervious claystone underlying the silicified material. A minimum age of 20 million years (m.y.) was obtained for the uraniferous silica and $32.4 \pm 2.6 \mathrm{~m} . \mathrm{y}$. for the overlying rhyolite tuff. These investigations show that uranium was being leached from ash and carried by ground water at the time the Shirley Basin deposits are though to have formed between 20 and 35 million years ago.

In a laboratory experiment to determine the rate of leaching of uranium and other elements from glass shards, Zielinski subjected samples of rhyolitic glass, including one sample from the White River Formation in the Shirley Basin, to attack by aerated alkaline solutions that approximated the composition of natural occurring waters in tuffaceous rocks. Fresh solution was eluted through each sample at a controlled rate, temperature and pressure. Although the experiments were run at $120^{\circ} \mathrm{C}$ and 7000 psi (to speed the rate of reaction), Zielinski believes that the general results would be similar in tests run at lower temperatures and pressures. The sample of shards from the Shirley Basin contained $5.6 \mathrm{ppm}$ uranium before leaching and $5.3 \mathrm{ppm}$ after leaching, with about $3700 \mathrm{ml}$ of solution in a period of 113 days. Slightly more than 5 percent of the uranium was removed from the glassy shards by the leach solution.

Laboratory tests and field evidence show that uranium can be and is being leached from granitic rocks by ordinary ground water. Harshman (1972) ran leach tests on 11 samples of granite from the Laramie and Shirley Mountains, rocks considered to be the sources of the arkose in the Shirley Basin. The samples contained from 0.5 to $7.0 \mathrm{ppm}$ uranium. They were crushed to about one-eighth inch so as to not pulverize the component minerals, and $50 \mathrm{~m} 1$ 
of a leach solution approximating the composition and $\mathrm{pH}$ of Shirley Basin ground water was dripped through 5 grams of the crushed granite in a ten-hour period. Although the contact time between solvent and granite was short, as much as 0.9 percent of the uranium in the samples was taken into solution, indisputable proof that granite can release uranium to ground water.

Analyses of water flowing in granitic terrains substantiate the laboratory evidence that ground water can leach uranium from granitic rocks. Samples of spring water from the granitic cores of the Laramie and Shirley Mountains, which flank the Shirley Basin on the east and west and which served as the source of the arkose in the basin, contained from 1 to $8 \mathrm{ppm}$ uranium (Harshman, unpublished data). The $\mathrm{pH}$ of the water ranged from 6.2 to 7.0 , the $\mathrm{SiO}_{2}$ content from 12 to $99 \mathrm{ppm}$, and $\mathrm{SO}_{4}^{2}$ content from 5 to $36 \mathrm{ppm}$ and the $\mathrm{HCO}_{3}^{-}$content from 24 to $92 \mathrm{ppm}$.

Less direct proof, but certainly suggestive that granite has contributed uranium and other elements to the Wyoming deposits are the studies of surface samples and drill core from the granitic rocks in the Sweetwater uplift. These rocks furnished much of the arkosic host sediment for the Shirley Basin, Gas Hills and Crooks Gap-Great Divide Basin areas. Both Rosholt et al (1973) and Stuckless and Nkomo (1978) find that samples of granite are greatly depleted in the amount of uranium required to produce the amounts of radiogenic lead in the samples. Based on uranium-thorium-lead isotopic analyses, these authors estimate a 70 to 75 percent depletion of uranium in granites during the last 40 million years (Stuckless and Nkomo, 1978) or according to Rosholt et al (1973) it occurred during the Mesozoic-Cenozoic periods. They propose that this lost uranium is the progenitor of the Wyoming deposits for several reasons: (1) the districts are on the flanks of the Granite Mountains; (2) the granites have lost large amounts of uranium; (3) the arkosic host rock does not appear to be a reasonable source of uranium; (4) radiometric dating of the ores by Ludwig (1978) suggests the ores are in part older than the volcanic source rocks; and (5) the timing of the uranium loss from the granite agrees with the radiometric date of the ores. These reasons do not necessarily support their conclusions nor do they disprove a tuffaceous source for the uranium because: (1) tuffaceous rocks of Middle and Upper Eocene age and of Early 0ligocene age are spatially more closely associated with the uranium deposits than are the granites; (2) the tuffaceous rocks are now supplying uranium to the ground water and may have supplied even more shortly after deposition and during the compaction of their ashy constituents; (3) the arkosic sandstone does not appear to be a likely source of uranium; (4) the ages determined by Ludwig (1979) of 25 to 35 million years for the Shirley Basin, Crooks Gap and Gas Hills deposits are younger, not older, than the 45.4 to 32 million year ages respectively for the Wagon Bed and White River tuffaceous rocks in the Granite Mountains area (Love, 1970) and Shirley Basin (Zielinksi, 1980); and (5) the timing of acidic volcanic activity and deposition of tuffaceous sediments in the central Wyoming area agrees well with the radiometric ages of the uranium deposits.

Ludwig (1979), using much of the same radiometric data as Stuckless and Nkomo (1978) concludes that, "the inferred limits on the time of mineralization in the two districts (Crooks Gap and Gas Hills) do not resolve the question of the major source material for the uranium except to require a source to have existed from at least 0ligocene time." The major source could have been 
either the granitic rocks in the cores of the uplifts that flank the Wyoming basins or the tuffaceous rocks of Eocene or Oligocene, age that overlie or once overlay the basins.

In summary, we may conclude from available data that neither magmatic-hydrothermal solutions, tectonic-hydrothermal solutions, nor expelled pore-water appear to be viable sources for the uranium and associated elements in the Wyoming deposits. It is also improbable that the host rock, either arkosic or quartzose, served as a major source of the elements. The most probable sources are the inordinately uraniferous granitic rocks that form the cores of the ranges that flank the Wyoming basins or the tuffaceous rocks of Eocene or younger age that overlie or once overlay the basins. The close association of tuffs and bentonitic volcaniclastic sediments with all but the Australian rolltype districts and with other sandstone uranium districts, including the Texas Coasta1 Plain, Grants Mineral Belt and Colorado Plateau regions, is compelling circumstantial evidence that such sediments have acted as sources but does not even imply that such was the case in all districts. The relative importance of the two potential sources can be inferred but not evaluated with available data. Resource appraisal or exploration programs should not yet be based on a single type of uranium source, i.e. granite or volcanic, but should favor those areas where one or more potential source rocks are identified.

\section{Character of Mineralizing Solutions}

There is general agreement among almost all investigators that ground water flow was the mechanism for the formation of the deposits and the alteration associated with them. As discussed previously, there is no evidence that hydrothermal solutions, either metamorphic or magmatic, were involved in the dissolution, transportation, and deposition of the elements in the deposits. On the contrary, there is considerable evidence that the solutions originated at or near the surface and moved down the flanks of the basins. Furthermore, all of the elements in the deposits and the character of the alteration associated with them can be related to the geochemistry of ground water under the environmental conditions extant in the Wyoming basins at the time the deposits are thought to have formed.

There is some disagreement on the character of the ground water. Harshman (1962) proposed that uranium was transported by weakly acid moderately oxidizing ground water, but pointed out the difficulty of reconciling such solutions with the Shirley Basin geologic environment. He subsequently (Harshman, 1966) concluded that the alteration accompanying the deposits was caused by neutral to somewhat alkaline, oxidizing ground water. Melin (1964, 1969) proposed that the Shirley Basin ore-bearing solution was acid ( $\mathrm{pH} 4-1 / 2+$ ), depleted of oxygen, and charged with $\mathrm{H}_{2} \mathrm{~S}$ and $\mathrm{CO}_{2}$. The source of the acidity and $\mathrm{H}_{2} \mathrm{~S}$ was sour gas from a "ruptured petroleum reservoir." Mineral deposition from the acidic solution was caused by an increase in $\mathrm{pH}$ at the edge of the altered tongue. Most recent investigators propose slightly alkaline oxidizing ground water as the mineral-bearing solution (Files, 1970; Rackley, 1976; Harshman, 1974). 
There is considerable data available on which to base a reasonable estimate of the character of the mineralizing solutions. The host rocks in the Wyoming basins are arkoses with considerable orthoclase and microcline, as well as a small percent of calcium carbonate. The White River and Arikaree Formations that overlie or once overlay the host arkoses are similar in composition, but in addition they contain considerable tuffaceous material either dispersed or in relatively pure tuff beds. Both the arkoses and the tuffs are alkaline environments and would tend to buffer any solutions flowing through them. Garrels and Christ (1965) show that water in contact with $\mathrm{CaCO}_{3}$ generally has a $\mathrm{pH}$ greater than 8.0, the exact figure is dependent on the partial pressure of $\mathrm{CO}_{2}$ and other factors. Hemley and Jones (1964) discuss at length the increase in alkalinity caused by hydrolysis of silicate minerals such as feldspar. Hay (1963) has shown that alteration of silica glass releases silica and alkali ions to ground water and produced $\mathrm{pH}$ values of 8.0 or higher. These theoretical considerations are confirmed by $\mathrm{pH}$ measurements of ground water in the Shirley Basin (Harshman, 1972), Powder River Basin (Sharp and Gibbons, 1964), Great Divide Basin (Sheridan et al, 1961), and Black Hills (Gott et a1, 1974). Almost without exception, the $\mathrm{pH}$ of ground water in these districts ranged from 7.0 to about 8.5 with an average $\mathrm{pH}$ of about 7.8 . Analyses of ground water samples from the Shirley Basin are shown in Table 2 . They are believed to be typical of most ground water in the other Wyoming basins. It is not our argument that the present ground waters compositions were necessarily extant during ore formation, only that present ground waters reflect conditions within the host rocks and that ground waters of more acid composition would not long endure.

Attempts to measure the oxidation-reduction potential of ground water from flowing wells in the Black Hills (Gott et al, 1974) met with some success and showed positive Eh values of as much as $+162 \mathrm{mv}$ near the outcrop of the host sandstone (Inyan Kara) to negative values of as much as $-200 \mathrm{mv}$ basinward from the ore deposits. The absolute $\mathrm{Eh}$ values cited above may be somewhat in error because of loss of $\mathrm{H}_{2} \mathrm{~S}$ and $\mathrm{CO}_{2}$ or addition of $\mathrm{O}_{2}$ as the waters approached the surface. Eh measurements were attempted in the Shirley Basin, but since there were no flowing wells in the area the samples were taken from surface springs and probably represented water in equilibrium with the atmosphere and thus not representative of waters in the host sandstone. Eh values in the Wind River (host rock) and the overlying White River in the Shirley Basin ranged from +300 to $+360 \mathrm{mv}$.

Considerable indirect evidence of alkaline, oxidizing, ore-bearing solutions can be found in the character of the alteration they effected and in the geochemistry of the elements transported by them. In previous sections of this report, we have described the alteration caused by the ore-bearing solutions, and in each district the changes are similar and resulted from oxidation of the constituents in the sandstone. Pyrite and marcasite have been largely destroyed and in their place we find goethite, hematite, and/or highiron montmorillonite. Carbonaceous plant debris has been largely destroyed, in part at least by oxidation to $\mathrm{CO}_{2}$. Ferrous/Ferric iron ratios, where available, are $1: 1$ or less in the altered sandstone, but at least $2: 1$ in unaltered sandstone.

A11 of the extrinsic elements in the deposits can be carried at normal temperatures and pressures in solutions of composition similar to present-day ground 
Table 2. Chemical analyses of water samples from wells, springs, and drill holes, Shirley Basin, Wyoming (from Harshman, 1972).

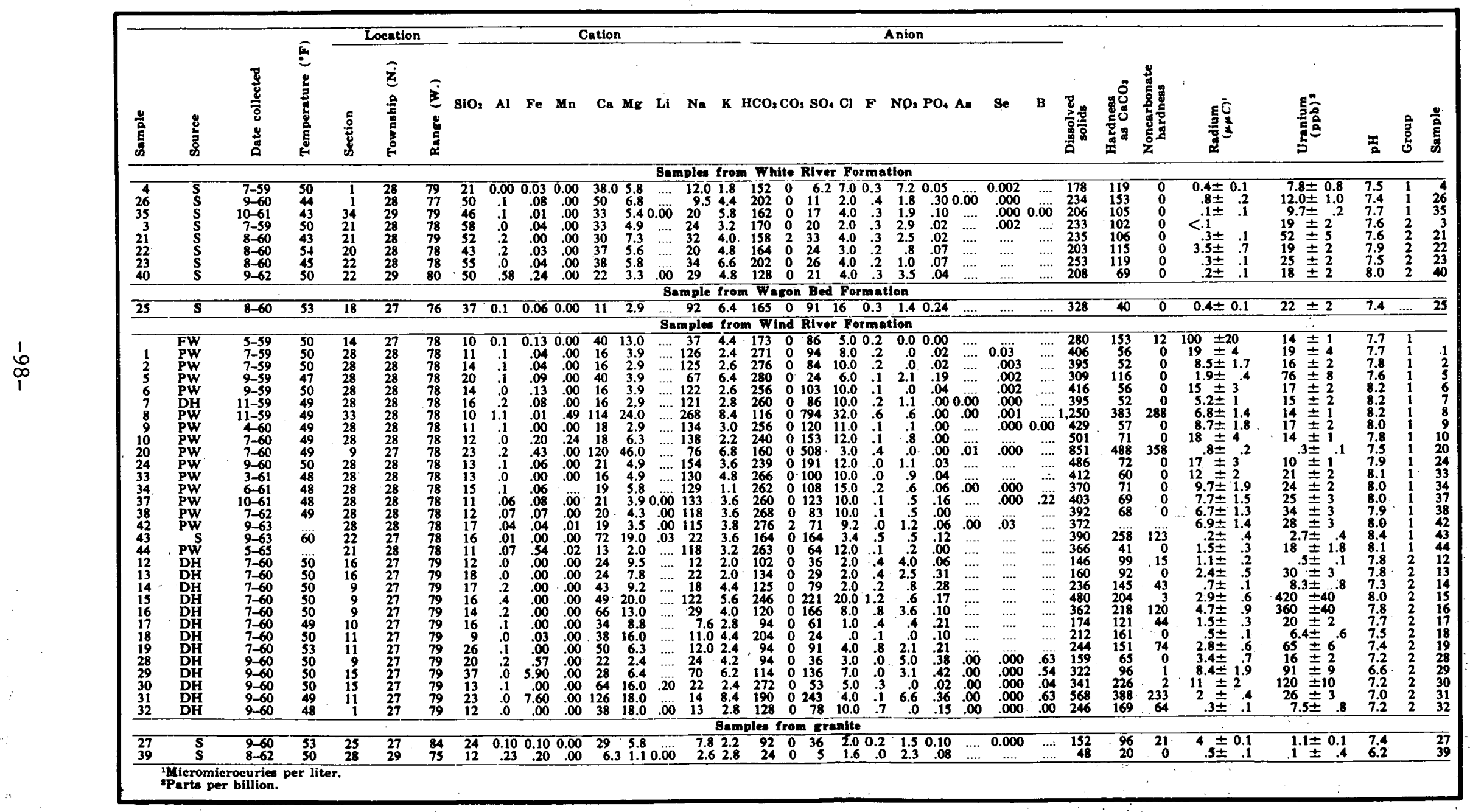


water in the Wyoming basins, but selenium must be carried in such solutions. According to Lakin (1961) selenium, under conditions in natural environments, can be taken into solution and transported only under alkaline oxidizing conditions. Selenite ion $\left[\left(\mathrm{Se}_{2} \mathrm{O}_{3}\right)^{-2}\right]$ is readily formed under acid or alkaline conditions and moderate oxidation potentials, but it is almost immediately immobilized by reacting with iron to form an insoluble precipitate of basic ferric selenite. Selenate ion is soluble in acid solutions but only under conditions much more rigorous than can be expected in nature. In solutions of $\mathrm{pH} 7$ and greater, containing several hundred $\mathrm{ppm} \mathrm{SO}^{2} \frac{-}{4}$ and $\mathrm{CO}_{3}^{2-}$, selenium is easily oxidized to selenate and carried by normal surface and/or ground water. Laboratory experiments by Warren (1968) suggest that selenium travels in ground water as a complex with sulfur. These complexes are stable in alkaline oxidizing solutions, but unstable in acid reducing solutions.

There is no direct evidence of the exact form in which the elements in the deposits were carried. Hostetler and Garrels (1962) have shown that uranium is soluble at normal temperatures and pressures in either the +4 or +6 valent state depending on the $\mathrm{Eh}$ and $\mathrm{pH}$ of the solution and its $\mathrm{CO}_{2}$ content. Solution in the +4 valent state $\left(\mathrm{UO}_{2}{ }^{+}\right.$) required $\mathrm{pH}$ and $\mathrm{Eh}$ values far higher than normally attainable in nature, but solution in the +6 valent state as a complex with carbonate $\left[\mathrm{UO}_{2}\left(\mathrm{CO}_{3}\right)_{2} \cdot \mathrm{H}_{2} \mathrm{O}=\right.$ ] is accomplished in ground waters similar to those shown in Table 2. Langmuir and Applin (1977) refined and expanded the work of Hostetler and Garrels and showed that uranium can be precipitated from ground waters far more dilute than generally assumed. In addition, he shows that uranyl ( +6 valent) ions formed predominant $(>50 \%)$ complexes with phosphate between $\mathrm{pH}$ 4.5-7.5. In the absence of phosphate, uranyl carbonate complexes predominate above $\mathrm{pH} 4.5$, but in the presence of $\mathrm{UO}_{2}\left(\mathrm{HPO}_{4}\right)_{2}$, they predominate only above $\mathrm{pH} 7.5$.

Vanadium, selenium, arsenic, and molybdenum all form oxygenated anionic complexes and can be carried in those forms by solutions of $\mathrm{pH}$ near 8 and Eh above $-200 \mathrm{mv}$, conditions extant in ground waters of the Wyoming basins. other elements in the ore are probably carried in solution as simple cations. It has also been shown that humic material complexes all the elements found in roll-type deposits, but there is no evidence that the dissolution, movement and reprecipitation of such organic matter is an integral part of roll front development.

Geochemistry at the Roll Front

The roll front, as considered by most geologists and as used in this report, is an oxidation-reduction interface for iron. This interface may, but almost always does not, coincide with redox interfaces for other elements. The roll front is a dynamic feature migrating down hydrologic gradient, generally basinward, by oxidation and solution on its updip side and reduction and deposition on its downdip side. Most geologists accept the concept of a migrating front, but there is some disagreement on the chemical and/or biochemical processes involved. Oxidation migration and reduction can be accomplished by biogenic or non-biogenic processes or by a combination of both. The all biogenic system has been described by Rackley at al (1968). It involves two families of bacteria functioning in two very restricted zones, 
under restricted conditions of $\mathrm{Eh}$ and $\mathrm{pH}$, and sharply separated one from the other by the roll front (Fig. 34). On the reduced side of the front, the left side in Figure 34, anaerobic bacteria of the genus Desulfovibrio predominate. They are sulfate reducers, derive their energy from organic matter in the sandstone or in solution, and produce $\mathrm{H}_{2} \mathrm{~S}$. Other bacteria may assist in breaking down cellulose into products usable by Desulfovibrio in its life process. These bacteria are strict anaerobes and create an environment of $\mathrm{pH}$ 7.8 to 8.4 and an Eh of $-200 \mathrm{mv}$ or less.

On the oxidized or altered side of the front, Thiobacillus ferrooxidans and related bacteria predominate. They are strictly aerobic, derive their carbon from $\mathrm{CO}_{2}$, their energy from nitrogen and sulfur compounds, hydrogen and iron, and they are capable of producing $\mathrm{pH}$ as low as 1.8 , although the optimum $\mathrm{pH}$ for maximum activity is from 2 to 4 . In addition to producing a low $\mathrm{pH}$, they are capable of producing Eh values as high as $+760 \mathrm{mv}$ although such high values are unlikely in a natural environment. Thiobacillus is thought to be an intermediate step in the conversion of pyrite to iron hydroxide and eventually to goethite, hematite, or high iron montmorillonite. The first step is the reaction of pyrite, ferric sulfate and water to produce ferrous sulfate and sulfuric acid; the seccond step the biochemical oxidation (by Thiobacillus) of ferrous sulfate and sulfuric acid to ferric sulfate and water and finally the hydrolysis of ferric sulfate to ferric hydroxide and sulfuric acid. Excess sulfate in the system is carried across the front into the reducing environment of Desulfovibrio where it is reduced to $\mathrm{H}_{2} \mathrm{~S}$.

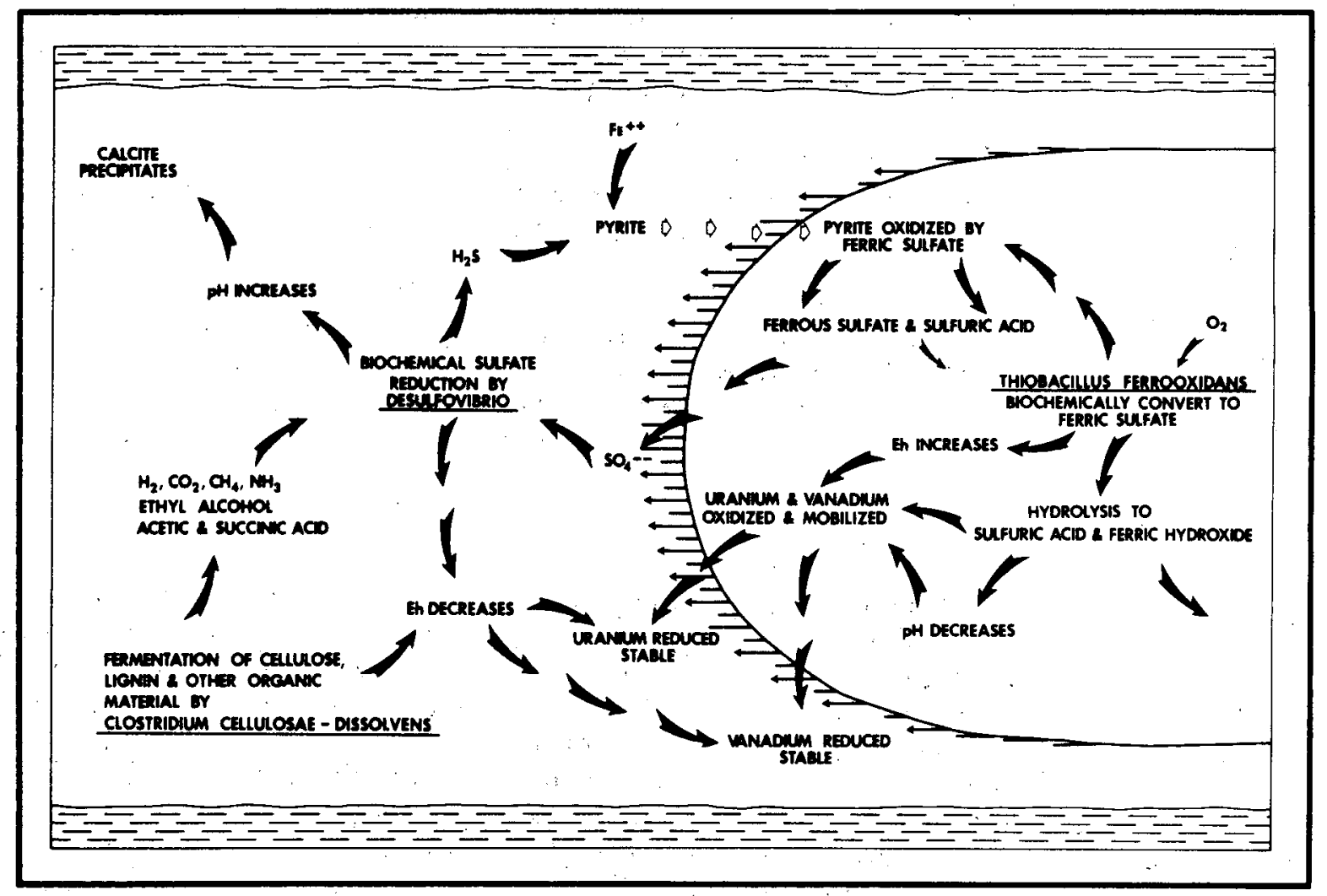

Figure 34. Some possible chemical reactions across a roll front, moving from right to left, during the period of mineralization (modified from Rackley, 1972). 
The biogenic system described by Rackley (1972) is almost self-perpetuating and needs only oxygen, pyrite ${ }^{2}, \mathrm{CO}_{2}$, and organic matter to complete the oxidation, migration, and reduction cycle required by a dynamic system of deposition. The needs of the system can be met by the host sandstone (pyrite, organic matter, $\mathrm{CO}_{2}$ ) and the ore-bearing solution (oxygen and $\mathrm{CO}_{2}$ ).

Some support is given the biogenic system by the investigations of Lisitsyn and Kuznetsova (1967). They sampled waters from wells and mine openings in and near roll-type deposits on the flank of an artesian basin at an undisclosed point in the U.S.S.R. From the limited geological data given by the authors, one can conclude that the deposit (or deposits) was similar in a11 major aspects to those found in the Wyoming basins, and that it was forming at the time of their investigation. The host rocks are permeable Cretaceous sandstones. They report a pH of about 7.5, an Eh of about $-200 \mathrm{mv}$ in the waters flowing in the mineralized zone. They conclude: (1) that the negative Eh results from the anaerobic activity of microflora that produce $\mathrm{H}_{2} \mathrm{~S}$ and $\mathrm{HQ}$; and (2) the character and distribution of elements within the deposit depend on the relative amounts of the various products of microbiological activity. Their data are difficult to analyze, but they seem to confirm the presence of " $\mathrm{H}_{2}$-forming" and " $\mathrm{H}_{2} \mathrm{~S}$-forming" bacteria in the water on the reduced and mineralized side of the oxidation-reduction interface, but the presence of "Thio-bacteria" in the oxidized sandstone near the interface is open to serious question.

The chemical-biochemical concept postulates that mineral-bearing solutions are alkaline and oxygenated when they approach the redox interface. Without the aid of bacteria, the solutions oxidize pyrite to sulfuric acid and ferrous sulfate. The oxidation process will be slow if pyrite is the only sulfide, but much faster if marcasite or other sulfur-deficient species are present. These products are carried downdip into the reduced mineralized zone where sulfate-reducing bacteria convert the sulfate to $\mathrm{H}_{2} \mathrm{~S}$ and the sulfuric acid is converted to gypsum by the alkaline environment of the slightly calcareous arkose.

Considerable work has been done in an effort to determine the role played by sulfate-reducing bacteria in the deposition of the reduced ore minerals. As early as 1910, Lindgren et al (1910) proposed that $\mathrm{H}_{2} \mathrm{~S}$ of biogenic origin was the precipitant for the sedimentary red bed copper deposits of New Mexico.

\footnotetext{
${ }^{1}$ S. R. Austin (written communication, 1980) correctly points out that "as long as there is a supply of sulfate in the ground water there is no need for sulfide to initiate the process. However, it is likely that once the process is started at least part of the sulfate will be provided by oxidation of pyrite or other sulfides, and if the sulfide is pyrite, oxidizing bacteria can, and most likely will, speed up the process and provide the continuous system described. - . . If the sulfide is a less stable species, such as marcasite, mackinawite, or griegite, and probably some other metal sulfides, the process has much less need of oxidizing bacteria." The biogenic system "requires no sulfur more reduced than sulfate for initiation, whereas the inorganic system" (described later) "requires sulfide, or intermediate-valence species."
} 
Thode, Kleerekoper and McElchern (1951) found that sulfate-reducing bacteria.... selectively reduce the lighter $\mathrm{S}^{32}$. Jensen (1958) and Cheney and Jensen (1966) published the results of sulfur isotope studies on pyrite from the Gas Hills. They found that both the diagenetic pyrite dispersed through the unaltered sandstone and the pyrite in the deposits had the wide isotopic spread in the $\mathrm{S}^{32} / \mathrm{S}^{34}$ ratios and the relative enrichment in $\mathrm{S}^{32}$ characteristic of $\mathrm{H}_{2} \mathrm{~S}$ of biogenic origin. Additional studies by Austin. (1970) reached the same conclusion.

Granger and Warren (1969) have shown that solution, migration, and redeposition of the elements along a roll front can be accomplished by inorganic chemical reactions and without the intervention of bacteria. They recognize the probability that the widely disseminated pyrite in the unaltered ground and that destroyed in the altered tongue is of biogenic origin and formed shortly after deposition of the host sediments. Their thesis is that oxidation of pyrite at the roll front is accomplished by the ore-bearing solution, but that the amount of oxygen in that solution is limited. This results in the formation of soluble, metastable, partly oxidized sulfur species which are carried downdip by the ore-bearing solution until they spontaneously undergo disproportionation; that is, they divide into equivalent amounts of more reduced species such as $\mathrm{H}_{2} \mathrm{~S}$, and more oxidized species such as sulfate $\left(\mathrm{SO}_{4}{ }^{2}\right)$. Sulfate is kinetically inert to further reduction or oxidation reactions and this leaves the more reactive reduced metastable sulfur species and $\mathrm{H}_{2} \mathrm{~S}$ to control the environment. Chemical theory and laboratory experiments support the above considerations and show that isotopic fractionation of sulfur, similar to that caused by biochemical reactions, can result from inorganic chemical reactions. It appears therefore, that a pyrite-bearing sandstone is completely capable of establishing and maintaining a roll front, once oxygenated waters are introduced, without the participation of any organic components whatsoever.

Some of the reactions proposed by Granger and Warren (1969) follow:

$$
\begin{aligned}
& 2 \mathrm{FeS}_{2}+5-1 / 2 \mathrm{O}_{2}+5 \mathrm{H}_{2} \mathrm{O} \rightarrow 2 \mathrm{FeO}(\mathrm{OH})+4 \mathrm{H}+4 \mathrm{HSO}_{3}^{-} \\
& 3 \mathrm{HSO}_{3}^{-} \rightarrow \mathrm{H}_{2} \mathrm{O}+\mathrm{H}^{+}+\mathrm{S}+2 \mathrm{SO}_{4}= \\
& \mathrm{FeS}_{2}+1-1 / 2 \mathrm{O}_{2} \rightarrow \mathrm{Fe}^{++}+\mathrm{S}_{2} \mathrm{O}_{3}= \\
& \mathrm{Fe}^{++}+2 \mathrm{~S}_{2} \mathrm{O}_{3}+\mathrm{H}_{2} \mathrm{O} \rightarrow \mathrm{FeS}_{2}+\mathrm{SO}_{4}=+\mathrm{HSO}_{3}+\mathrm{H}^{+} \\
& \mathrm{OH}+\mathrm{S}_{2} \mathrm{O}_{3}=\mathrm{HS}^{-}+\mathrm{SO}_{4}= \\
& \mathrm{HS}+\mathrm{Fe}^{++} \rightarrow \mathrm{FeS}^{+} \mathrm{H}^{+} \\
& \mathrm{H}_{2} \mathrm{~S}+\mathrm{Fe}^{++} \rightarrow \mathrm{FeS}_{2}+2 \mathrm{H}^{+} \\
& \mathrm{FeS}+\mathrm{SO}_{\mathrm{O}} \rightarrow \mathrm{FeS}_{2}
\end{aligned}
$$

Two other reductants have been proposed because of their spatial relation to the deposits. Coalified woody-material, or humates derived from such material, are present in a11 of the host rocks of the Wyoming deposits. For this reason, as well as for the fact that some ore contains as much as 0.5 to 1.0 percent 
organic carbon, some investigators suggest that organic carbon is the direct reductant of uranium and associated elements. While some samples containing 0.50 percent or more uranium contain 0.50 to 1.0 percent organic carbon, other samples with similar amounts of uranium contain a trace or a few hundredths percent organic carbon (Grutt, 1957; King and Austin, 1966; Harshman, 1972, 1974; Files, 1970). A sandstone with a high carbon content very close to ore may contain little or no uranium. Figures 36 and 41 of this report show a correlation between high uranium and high organic carbon in a sample of ore in the Shirley Basin, but two samples respectively 5 and 10 feet down dip from ore with equally high organic carbon contents contain essentially no uranium $(20 \mathrm{ppm})$. A comparison of the uranium and organic carbon contents of the Gas Hills sample suite (Figs. 36 and 41) shows little or no correlation between uranium and organic carbon. By contrast, the data of King and Austin (1966) as represented in Figure 42 may be interpreted to demonstrate the high organic carbon content of sands extending from the roll front toward unaltered sandstone. These data suggest that the correlation between uranium and organic carbon within the roll-type system is neither simple nor consistent, hence the precipitation of uranium by organic material may not be the only important mechanism. Studies by Schmidt-Collerus (1969, 1979), Kochenov (1965), and others, suggest that the organic matter may initially complex uranium from solution to subsequently be reduced by the oxidation of some combination of carbon and sulfide, and perhaps other elements.

The close spatial relation between the uranium deposits in the Wyoming basins and Cretaceous Formations that are oil and/or gas-producing in Wyoming, suggests a possible genetic relation between uranium deposition and $\mathrm{H}_{2} \mathrm{~S}$ from sour gas. Grutt, 1957 。 concluded that $\mathrm{H}_{2} \mathrm{~S}$ derived from sour gas was the precipitant for the ore minerals in the Gas Hills area. He pointed out that producing oil and gas wells are adjacent to the area, that the gas from the wells contains as much as 2 percent $\mathrm{H}_{2} \mathrm{~S}$, that there are gas seeps in the area, and that exploration drilling encountered $\mathrm{H}_{2} \mathrm{~S}$ in the Wind River Formation. He proposed that sour gas ascended along the faults that border the district on the south, entered the unconformity at the base of the Wind River Formation, and entered the host sandstone where it rested on the unconformity.

Subsequent investigations by Cheney and Jensen (1966) determined that the sulfur in the pyrite in the Gas Hills orebodies was much lighter than in four samples of $\mathrm{H}_{2} \mathrm{~S}$ they collected from wells in the area. They rejected Grutt's proposal. Still later, investigations by Vredenburgh and Cheney (1971) on the isotopic compositions of the crude oils, sulfate waters, and $\mathrm{H}_{2} \mathrm{~S}$ associated with the oils lead them to conclude among other things that

if the original petroleum-derived hydrogen sulfides were depleted in $\mathrm{S}^{34}$ compared to the petroleum from which they were generated, they might have had compositions similar to [samples] $\mathrm{GH} 2,93$, and 94. Accordingly, Grutt's hypothesis could have considerably more merit than Cheney and Jensen thought. Nonetheless, pyrite enriched in $S_{32}$ and calcite enriched in $\mathrm{C}^{22}$ occur around woody material as well as in asphalt in the Gas Hills district, a fact suggesting that bacterially-generated hydrogen sulfide was also important.

Although these documentations leave us undecided as to the role of introduced sulfur, it is noteworthy, as discussed elsewhere, that at least one of the Gas 
Hills ores was inordinately high in iron sulfides and that uranium is generally separated from altered sandstone (Fig. 47) by a zone containing iron sulfides. These differences may suggest unique conditions in the Gas Hills but as of this moment, the data neither prove nor disprove the proposal that $\mathrm{H}_{2} \mathrm{~S}$ from sour gas was the precipitant for the Gas Hills deposits.

We have examined several chemical, biochemical, and chemical-biochemical systems that may be operative at the roll front and account for its basinward (downdip) migration. There is no certainty that any one system was operative at all times in the districts discussed. However, recent work by Goldhaber and Reynolds (1979) on marcasite in the Texas and Wyoming deposits has furnished data that may be used to determine the probable nature of the reductant responsible for a particular deposit. They have shown theoretically and by laboratory studies that one of the dominant factors in the formation of marcasite or pyrite as ore-stage minerals is

the complex interrelationship of $\mathrm{pH}$ and sulfur species that are the precursors of iron-disulfide minerals. Experimental work and study of geochemical environments analogous to those governing the formation of the roll-type deposits indicate that relatively low $\mathrm{pH}$ (1ess than about six) and the presence of elemental sulfur favor marcasite, whereas higher $\mathrm{pH}$ and the presence of polysulfide ions favor pyrite.

Conditions that favor marcasite as the dominant ore-stage iron disulfide are most likely to arise in non-carbonaceous rocks. In rocks with considerable organic matter "the presence of polysulfide lons and $\mathrm{pH}$ buffering by anaerobic bacterial metabolic processes apparently lead to the formation of ore-stage pyrite." In the preceding descriptions of the Wyoming ro11-type deposits, we have noted that most of the ore-stage iron sulfide minerals are pyrite--a clear implication that biochemical activity was responsible for reduction of the deposits. Austin (1970) reached a similar conclusion based on his sulfur isotope studies of the Wyoming deposits, noting the well-defined oxidationreduction interface for iron, the lack of identification of intermediate sulfur species resulting from non-biochemical processes, and the ubiquitous nature of sulfate-reducing bacteria.

Age

Rol1-type uranium deposits have been described earlier in this report as occurring in rocks ranging in age from Early Cretaceous to Early Tertiary. They are considered to be similar in their geometry, their relation to altered sandstone tongues, their mineral composition and distribution, and in their genesis. Although their absolute age may be similar, the deposits in Cretaceous rocks differ from those in Early Tertiary rocks in the sequence of events from the time of deposition of the host rocks to the time of deposition of the uranium deposits. The deposits in the Early Tertiary rocks might be termed consequent deposits, for they are closely related to the hydrologic system responsible for deposition of the host rock. Mineralization followed very shortly (geologically) after deposition of the host rock and mineralizing fluids moved in response to the same hydraulic gradients responsible for deposition of the host. The deposits are the result of a single major cycle 
of uplift, erosion, sedimentation, and mineralization, hence the evaluation of their uranium potential is more straightforward.

In contrast to the Early Tertiary deposits, those in Cretaceous rocks might be termed subsequent deposits. for they are related only to the physical and chemical nature of the host rocks, not to the hydrologic system responsible for host rock deposition. They were formed long after deposition of the host rocks under a second cycle of uplift, erosion, and deposition, unrelated hydrologically and in time to the cycle responsible for the host rock.

Age determinations on such relatively young deposits as those in the Wyoming basins require precise analytical procedures and until the early 1970's most of the students of roll-type deposits based their age estimates on geologic evidence and intuition. Estimated ages ran the gamut from Eocene to Recent but the period from 011 gocene to Pliocene has been most frequently proposed. Isotopic lead-lead and uranium-lead ratios determined on samples of ore at shallow depths in the Powder River Basin (Sharp et al, 1964) indicated ages of from 4.5 to 13 million years and the authors proposed a Middle or Late Tertiary age for the deposits. Using total lead-total uranium ratios for 15 high-grade samples of ore from the Shirley Basin, Harshman (1970) determined ages of from 10 to 40 million years and an average of about 18 million years. The errors inherent in this method of age determination were recognized.

As age dating techniques improved, more reliable ages became available. Dooley, Harshman, and Rosholt (1974) determined uranium-lead ages on two samples of massive uraninite from the Gas Hills and Shirley Basin, as well as on three samples of high-grade ore from the two districts. The age calculations were made from the ${ }^{206} \mathrm{~Pb} /{ }^{23}{ }^{3}$ and ${ }^{20}{ }^{2} \mathrm{~Pb} /{ }^{235} \mathrm{U}$ ratios. The massive uraninite samples gave an age of $22 \pm 3$ million years for both districts. The high-grade ore samples gave ages of from 29 to 22 million years (Middle Oligocene to Early Miocene). The authors conclude that the $22 \pm 3$ million year (earliest Miocene) age is the most reliable.

More recent age determinations have been made by Ludwig on samples of uraninite from the Shirley Basin (Ludwig, 1978), and the Gas Hills and Crooks Gap (Ludwig, 1979). Ludwig found that even in the massive uraninite samples from the Shirley Basin there had been considerable uranium-daughter migration. He concludes

Impermeable ores, containing minerals that have fixed mobile radiogenic lead, present the most favorable samples for reliable uranium ore geochronology. One such ore sample (calcite-cemented, $12 \% \mathrm{U}$, having abundant pyrite intergrown with the pitchblende) yielded $\mathrm{U}-\mathrm{Pb}$ isotopic systematics that limit the age of the ore to between $12 \mathrm{~m} . \mathrm{y}$. and $27 \mathrm{~m} . \mathrm{y}$.

His study of the Gas Hills and Crooks Gap ores (Ludwig, 1979) lead to the conclusion that

$\mathrm{U}-\mathrm{Pb}$ isotope analyses of uranium ores from the Gas Hills and Crooks Gap districts indicate that ores from both districts are at least as old as Oligocene. The data from the highest-ranked samples (in terms 
of suitability for $\mathrm{U}-\mathrm{Pb}$ isotope dating) give $\mathrm{U} / \mathrm{Pb}$ isotope apparent ages in the range of 25 to $35 \mathrm{~m} \cdot \mathrm{y}$.

with ages as young as 28 to $30 \mathrm{~m} . \mathrm{y}$. being the most probable.

A concept not widely accepted, but deserving of serious consideration, proposed that the deposits in the Wyoming basins were formed concurrent: with the deposition of the host rock or very shortly thereafter. Childers (1974) relates the development of the roll-type uranium deposits that are found in Cretaceous, Paleocene, and Eocene host rocks to the climatic conditions extant in Eocene and early Oligocene time. He states that,

During Eocene and Early 01igocene time, fluvial deposition under the influence of a savannah climate with pronounced cyclic precipitation resulted in the development of two major facies which grade laterally and vertically into each other. These facies include (1) an oxidized facies, consisting of red and grey, banded mudstone and thin lenticular sandstone and conglomerate; and (2) a reduced facies consisting of thick; welldeveloped carbonaceous sandstone and conglomerate associated with carbonaceous mudstone and some extensive coal beds.

He defines a savannah climate as being hot and moist with pronounced long and short term fluctuations in precipitation. His climatic assumptions are supported by vertebrate and plant fossil evidence. He postulates that oxidizing, uranium-bearing waters from small intermittant tributary drainages in the oxidizing environment invaded reducing environments of the large permanent streams (and, in some cases subcropping Pre-Eocene sandstones) to produce the oxidized tongues and the associated uranium deposits. Drainage patterns which controlled the deposition of the host rocks also controlled the positions of the altered sandstone tongues and the deposits associated with them. The savannah climate persisted into Early oligocene time when the climate moderated and became more temperate. Vertebrate fossil evidence supports this change, and few if any roll-type deposits are found in sedimentary rocks deposited after this climatic change.

The general trend in thinking on ages of mineralization in the Wyoming basins is toward ages closer to the host rock ages. Bailey (1969), who originally postulated ages of "Miocene or later" for the deposits at Crooks Gap, now believes them to have been formed during deposition of the Early Eocene host rock. He believes that uranium-lead isotope apparent ages are entirely unreliable and cites an exposure where a conglomerate-filled channel may have cut into a mineralized tabular siltstone interbedded with fine- to coarsegrained sandstone (Bailey, 1980). Analyses show that two siltstone fragments in the channel fill contained 0.02 and 0.03 percent $U_{3} \mathrm{O}_{8}$; samples of siltstone and mudstone, in place contained from $0.0 \mathrm{i}$ ro 0.09 percent $\mathrm{U}_{3} \mathrm{O}_{8}$ and several sandstones interbedded with the siltstone contained 0.01 percent $\mathrm{U}_{3} \mathrm{O}_{8}$ (or possibly less since the $\mathrm{U}_{3} \mathrm{O}_{3}$ analyses are reported to the nearest 0.01 percent). It is possible that this mineralization is related to syngenetic uranium deposited in fine-grained carbonaceous sediments, particularly since the more permeable sandstones lying between the mineralized siltstones contain almost no uranium $(0.01+\%)$. The conclusion, drawn from this single exposure in the Seismic Mine at $\bar{C}$ rooks Gap, that some of the uranium deposits in that 
district are Eocene in age may be warranted, but the "extension (that) most of the deposits in Eocene rocks in Wyoming are Eocene in age" does not seem justified by the evidence presented.

Reliable isotopic apparent ages on the Black Hills deposits are not available. Vickers (1957) proposed an age related closely to the Pre-0ligocene period of erosion and oxidation noted in the Black Hills area. Gott and others (1974) imply, but do not definitely state, that they think deposition has been more or less continuous since 0ligocene time and is going on today. Lacking more specific data on which to base an apparent age for the Black Hills deposits, it seems reasonable to assume that they are about the same age as the Powder River Basin deposits, for the west flank of the Black Hills and the east flank of the Powder River Basin have had about the same geologic, climatologic, and hydrologic histories since uplift of the Black Hills and downwarp of the basin in Laramide time.

In summary, it may be said that all available data suggests that mineral deposition may have begun as early as middle Eocene time, but certainly not later than middle 0ligocene time, and may have continued for several hundred thousand years (Granger and Warren, 1978) or several million years (Ludwig, 1979).

Some of the deposits, particularly those associated with limonite-bearing altered tongues (i.e., Powder River Basin) may have undergone recent remobilization, migration, and redeposition of elements in the original deposits.

The apparent Middle Eocene to Middle Oligocene age of the uranium deposits in the Shirley Basin, Gas Hills, and Crooks Gap districts suggests that mineral deposition occurred at relative shallow depths, for by Middle Oligocene time the pile of tuffaceous rocks overlying the Late Paleocene or Early Eocene host sandstones was not more than 500 to 1,000 feet thick and may have been considerably thinner. The early Tertiary age suggests also that the deposits formed during or shortly after periods when volcanic activity contributed large volumes of ash to the overlying Wagon Bed and White River Formations. It is believed to be more than coincidence that the deposits formed shortly after the first appearance of tuffaceous material in the Tertiary stratigraphic sequence, at a time when volcanic debris should be most susceptible to leaching by percolating ground water, and at a time when there had been little change in the hydrologic conditions extant when the host rocks were deposited.

\section{Distribution of Elements}

There is a striking similarity in the distribution of elements and minerals in all of the roll-type uranium deposits on which detailed studies have been made. Neither the size of the deposit nor the geologic environment in which it is found seem to have had much affect on this distribution, a fact that suggests similar genetic processes were responsible for all roll-type deposits. Since any theory of origin must explain the presence and position of all elements in the deposits, the following data are presented as additional constraints on ore genesis speculations. 
The distribution patterns for pyrite and ten elements in the Shirley Basin, Gas Hills, and Black Hills deposits, are shown graphically in Figures 35 through 46. Also shown are distribution patterns for some elements in three uranium deposits in Texas. These deposits are not discussed in this report, but are the subject of a separate report. The illustrations are sections across the edges of altered sandstone tongues and the ore associated with them. In each illustration the ore-bearing solution moved from left to right as indicated in the schematic cross section, and the edge of the altered tongue is marked by the vertical dashed line. Where the concentration lines for pyrite and the various elements are dashed, analytical data has been projected into plane of section, but the distance from the roll front has been preserved. Included for comparison purposes (Table 3) are analytical data on two suites of samples collected by King and Austin (1965) across altered sandstone tongues and mineralized sandstone, Gas Hills, Wyoming.

\section{Pyrite-Marcasite}

Pyrite has been added to and is most abundant in reduced mineralized sandstone at the edges of the altered sandstone tongues (Fig. 35). It gradually decreases in amount away from the edges toward unaltered sandstone and in most deposits it extends farther away from the altered sandstone than does uranium. Pyrite has been destroyed in most of the altered oxidized tongues although some tongues contain minor amounts of pyrite and marcasite, particularly near their edges. Marcasite is most abundant (with pyrite) in mineralized reduced sandstone at and adjacent to the edges of the altered tongues. Pyrite and marcasite in altered sandstone may result from either incomplete oxidation of ore-stage pyrite-marcasite or from post-ore sulfidization and reduction of hematite, limonite, and goethite. The relative position of pyrite in the Gas Hills sample suite is typical of the district, but the amount (exceeding $40 \%$ ) in the samples from this ore zone is much higher (5 to 10 times) than in the average ore-bearing zone.

\section{Uranium}

Uranium has been added to reduced sandstone in zones close to or in contact with the edges of altered sandstone tongues (Fig. 36). The oxidation-reduction interface for uranium coincides with that for iron in about half the deposits studied; in the other half the uranium oxidation-reduction interface is separated from the iron interface by as much as 15 feet of pyrite-bearing reduced sandstone. The uranium content of altered sandstone is slightly greater (at $6 \mathrm{ppm}$ ) than that of unmineralized reduced sandstone (2 to $4 \mathrm{ppm}$ ), at least within 1000 feet of the roll front.

\section{Selenium}

Selenium is present in all deposits studied (Fig. 37). It has been deposited in narrow zones at the edges of the altered tongues, astride the edges, or in reduced mineralized sandstone close to the edges. Selenium in the altered sandstones may be present as ferroselite $\left(\mathrm{FeSe}_{2}\right)$ or native selenium, but in the reduced sandstones it is generally present as native selenium. Analytical data on samples of pyrite from mineralized, reduced sandstone near the roll front show that some pyrite grains may contain only trace amounts (Files, 1970). Selenium distribution in marcasite is similar to that in pyrite but in 


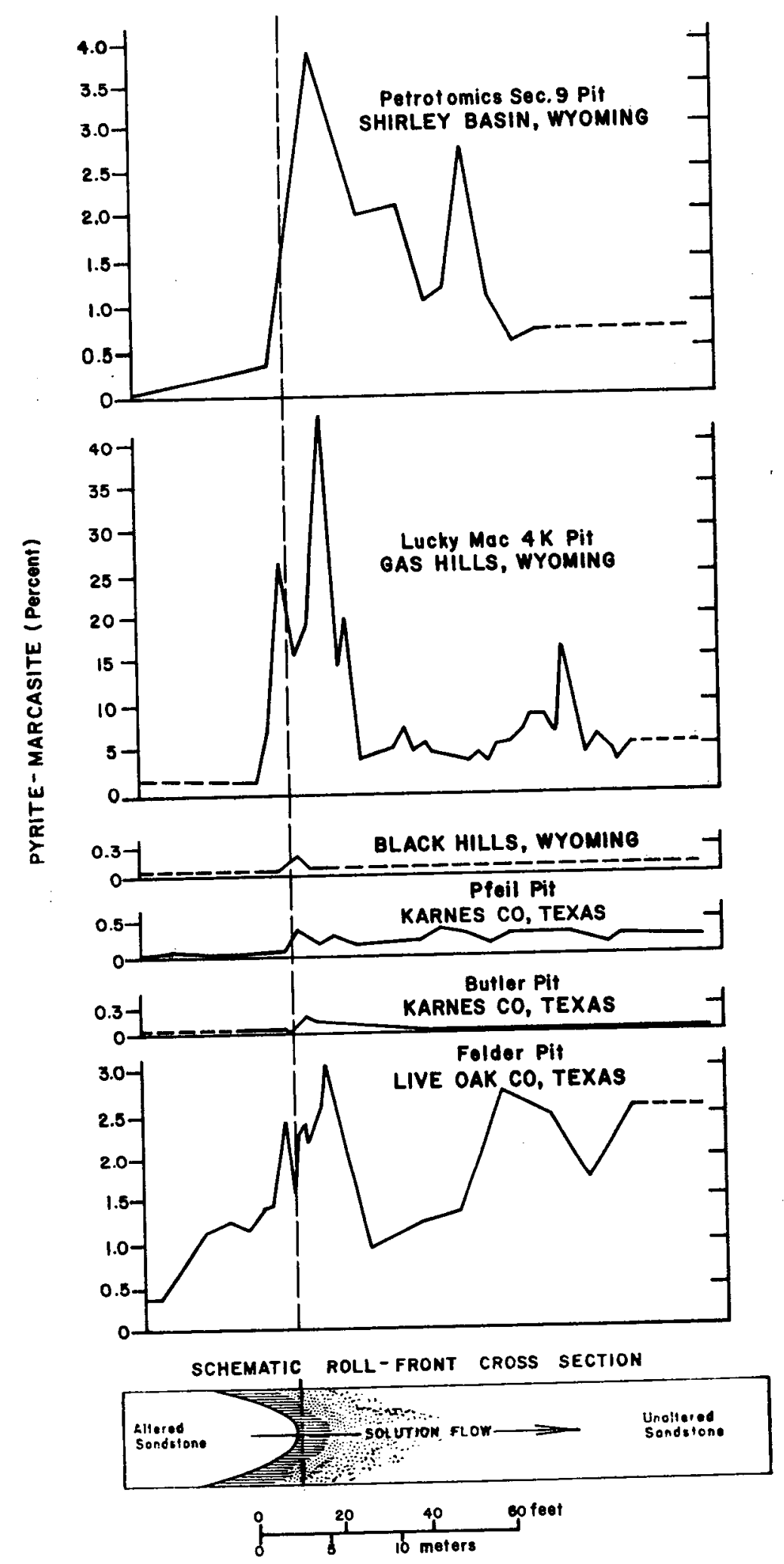

Figure 35. Distribution of pyrite-marcasite in roll-type uranium deposits in Wyoming, South Dakota, and Texas (modified from Harshman, 1974). 


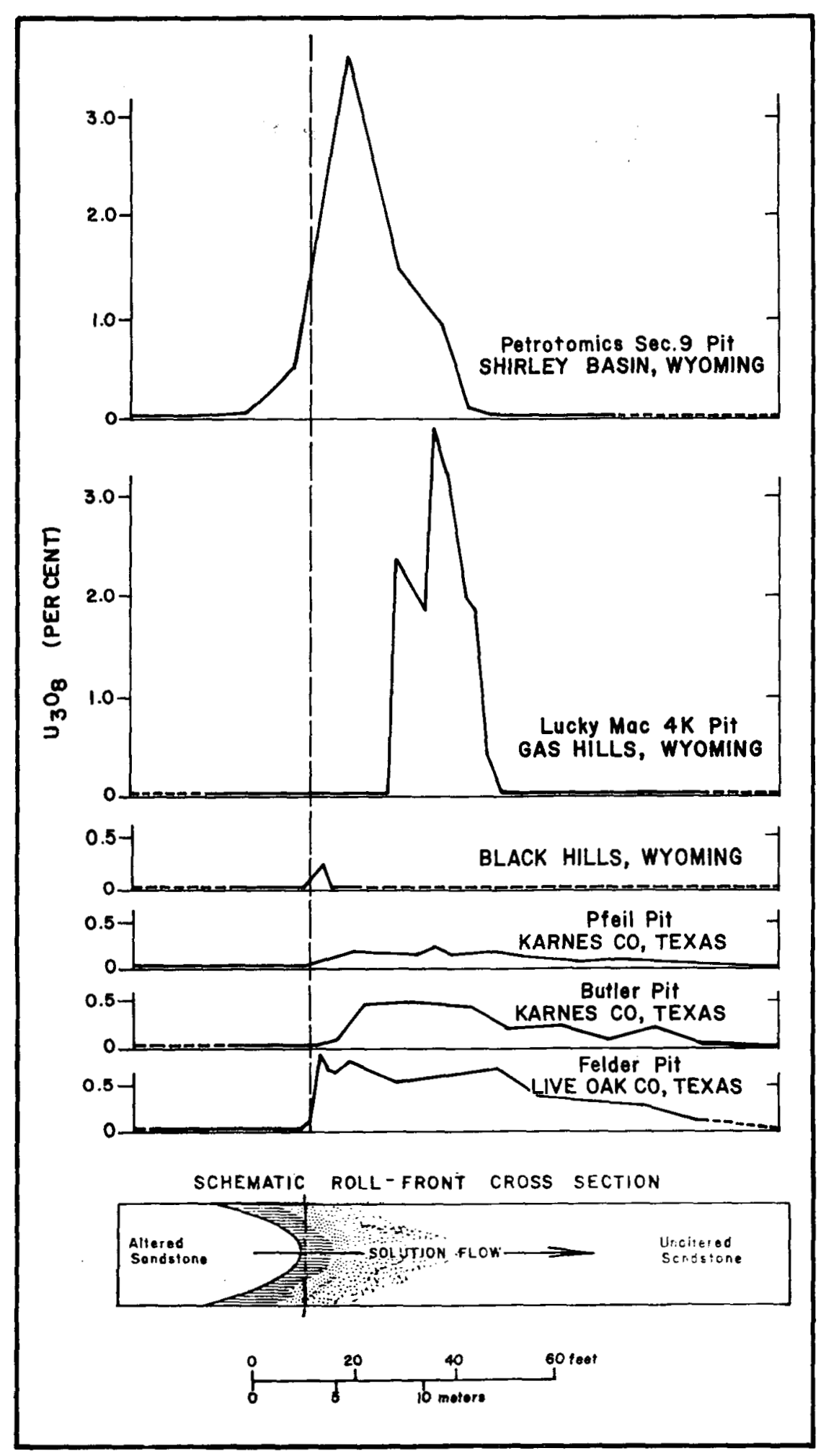

Figure 36. Distribution of uranium as $\mathrm{U}_{3} \mathrm{O}_{8}$ in rol1-type uranium deposits in Wyoming, South Dakota, and Texas (modified from Harshman, 1974). 


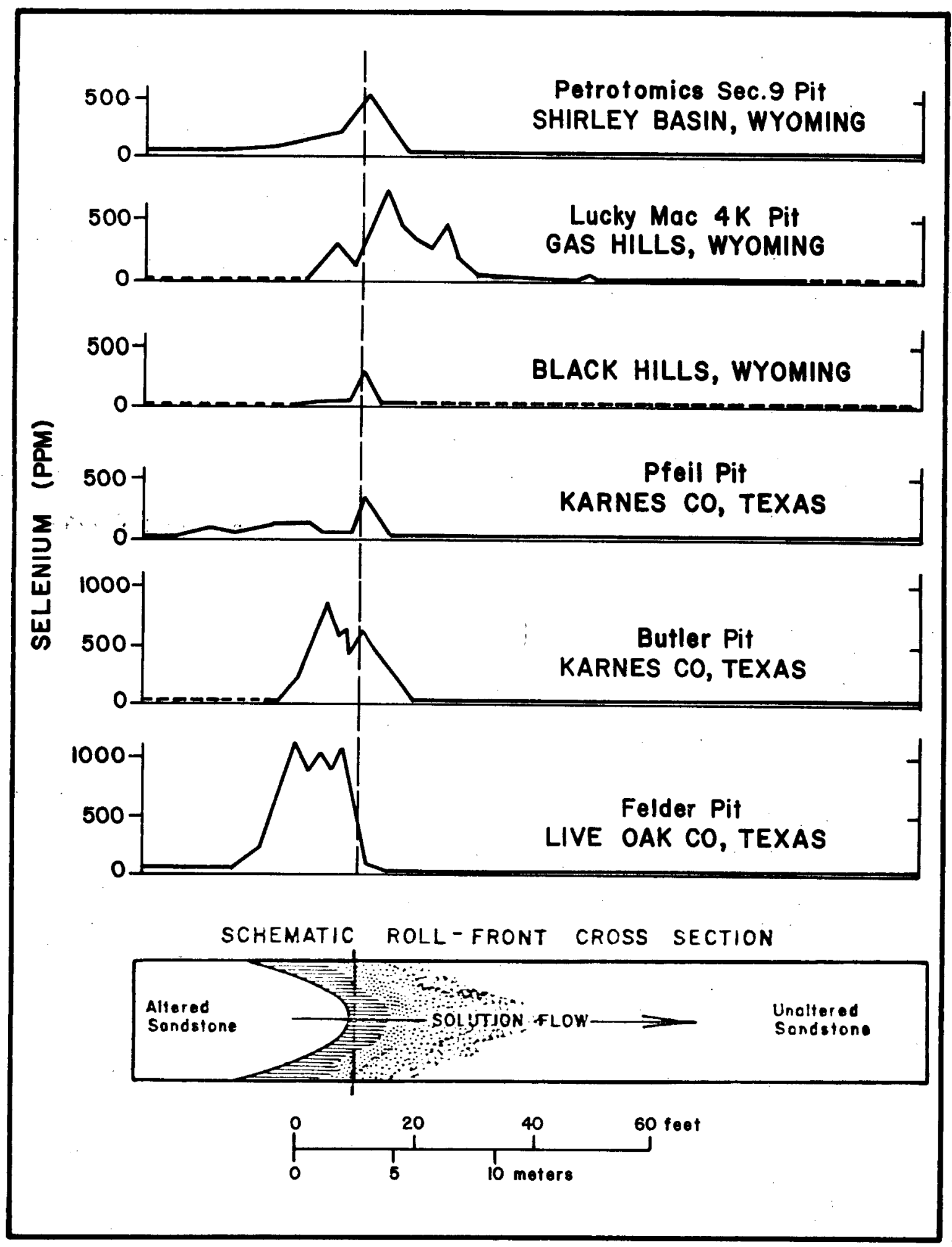

Figure 37. Distribution of selenium in roll-type uranium deposits in Wyoming, South Dakota, and Texas (from Harshman, 1974). 
lesser amounts. The amounts of selenium in the altered sandstone tongues are always greater than in unaltered unmineralized sandstones, sometimes by one order of magnitude.

\section{Vanadium}

Most roll-type uranium deposits contain only a few hundred parts per million (ppm) vanadium, but those in the Black Hills region may have vanadium contents equal to or several times the amount of uranium (Fig. 38). Vanadium has been deposited in mineralized reduced sandstore in a zone close to the roll front where it overlaps the zones in which ferroselite, pyrite and uranium have been deposited. Altered sandstone contains more vanadium than does unmineralized reduced sandstone, possibly admixed with iron oxides.

\section{Molybdenum}

Most rol1-type uranium deposits contain significant amounts of molybdenum in reduced sandstone at the distal edges of the mineralized zone (Fig. 39). The Shirley Basin deposits contain less than $3 \mathrm{ppm}$ molybdenum. Amounts range from a few tens of $\mathrm{ppm}$ to several percent, and are relatively high in the Gas Hills compared with the Shirley Basin and Black Hills area. Dahl and Hagmaier (1976) report molybdenum absent in the Powder River Basin, and Bailey (1969) reports as much as $45 \mathrm{ppm}$ molybdenum in the Crooks Gap deposits. The molybdenum is probably contained in the mineral jordisite $\left(\mathrm{MoS}_{2}\right)$, although no positive identification has been made. The molybdenum content of altered sandstone is slightly lower than that of unaltered reduced sandstone.

\section{Iron}

Iron, principally as pyrite and to a lesser extent as marcasite, has been added to reduced sandstone at and for some distance away from the edges of the altered tongues (Fig. 40). In some deposits the amounts added were small and there is little difference in the total iron content of samples from unaltered and mineralized sandstone, for example the Black Hills. In other deposits the iron content of mineralized sandstone may be an order of magnitude greater than in unmineralized reduced sandstone, for example the Gas Hills. The total iron content of altered sandstone may be equal to or somewhat less than that in unaltered sandstone. Ferric iron predominates in altered sandstone, ferrous iron predominates in unaltered reduced sandstone.

\section{Carbon}

Both mineral and organic carbon range greatly in their amount and their distribution (Figs. 41 and 42). Organic carbon content is less than 0.05 percent in the unaltered sands associated with some deposits and is as high as 2 percent in others. Even where it is a significant component of the sands, its erratic distribution in detail makes "average" concentration values of questionable value. Similar ranges are shown for mineral carbon (principally calcite). In most deposits, both organic and mineral carbon contents are higher in reduced sandstone than in altered oxidized sandstone. There seems to be no consistent direct correlation between the organic carbon and uranium contents of mineralized sandstone, a fact that throws some doubt on the belief that organic carbon was directly involved in the precipitation of uranium in roll-type 


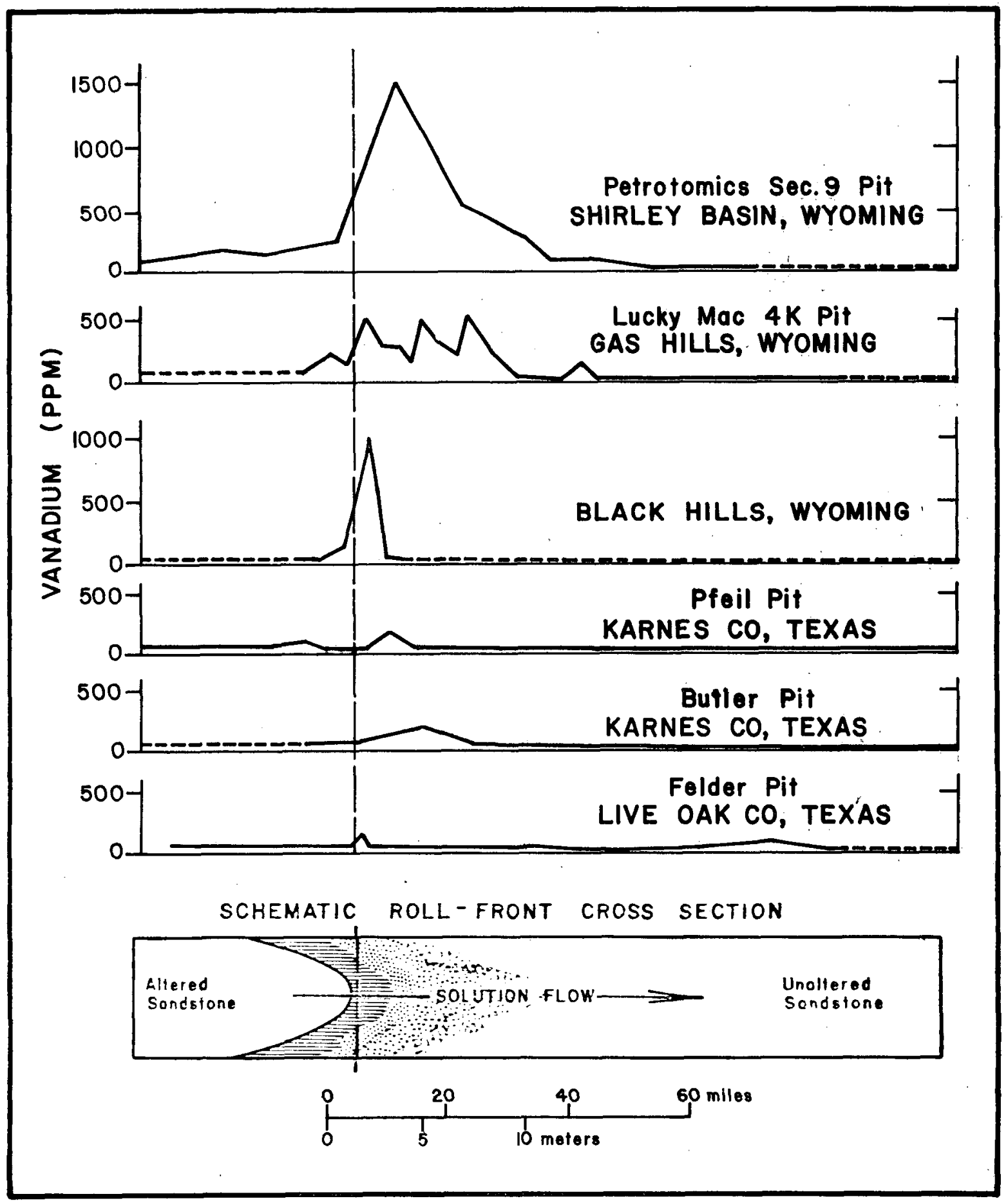

Figure 38. Distribution of vanadium in roll-type uranium deposits in Wyoming, South Dakota, and Texas (from Harshman, 1974). 


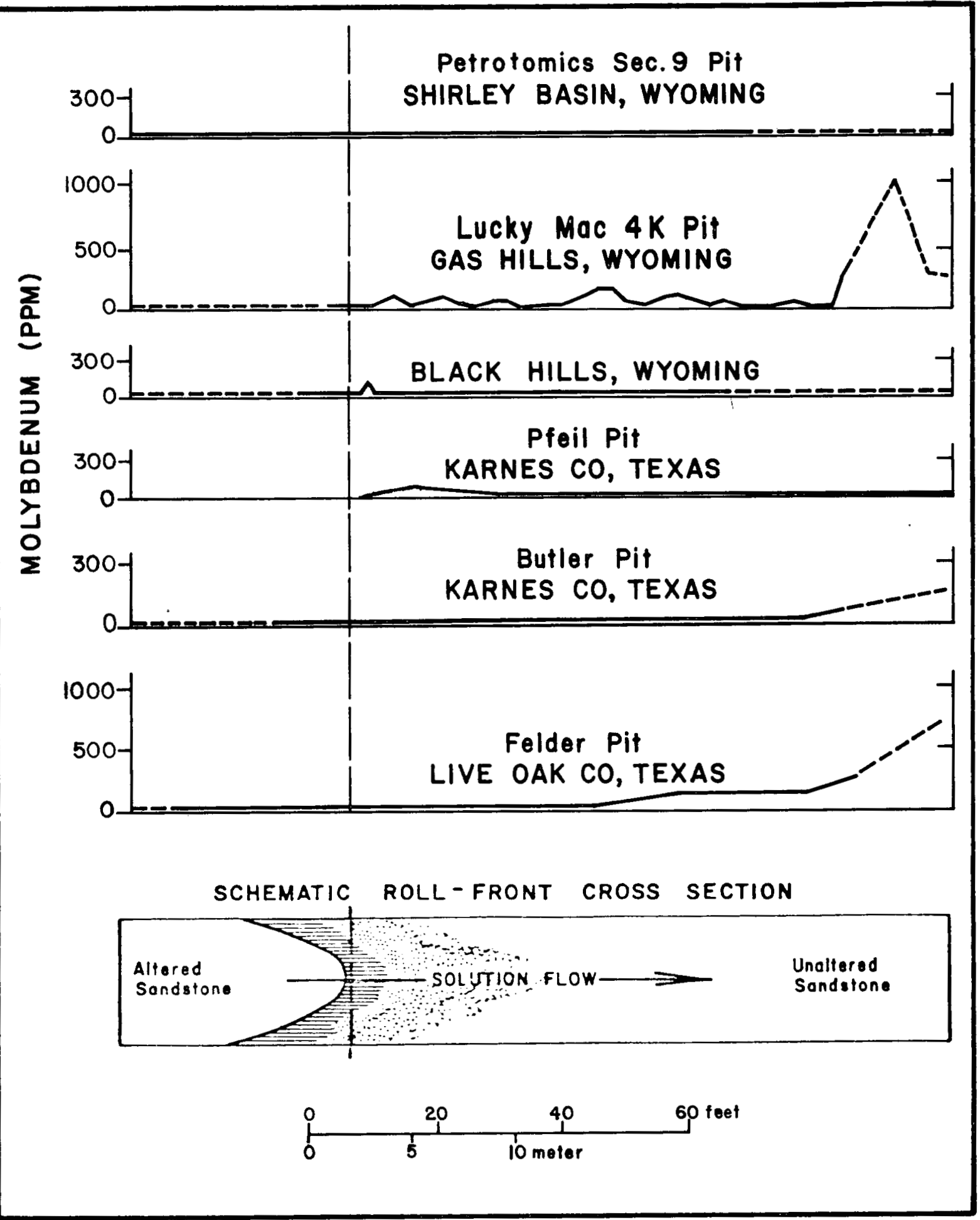

Figure 39. Distribution of molybdenum in rol1-type uranium deposits in Wyoming, South Dakota, and Texas (from Harshman, 1974). 


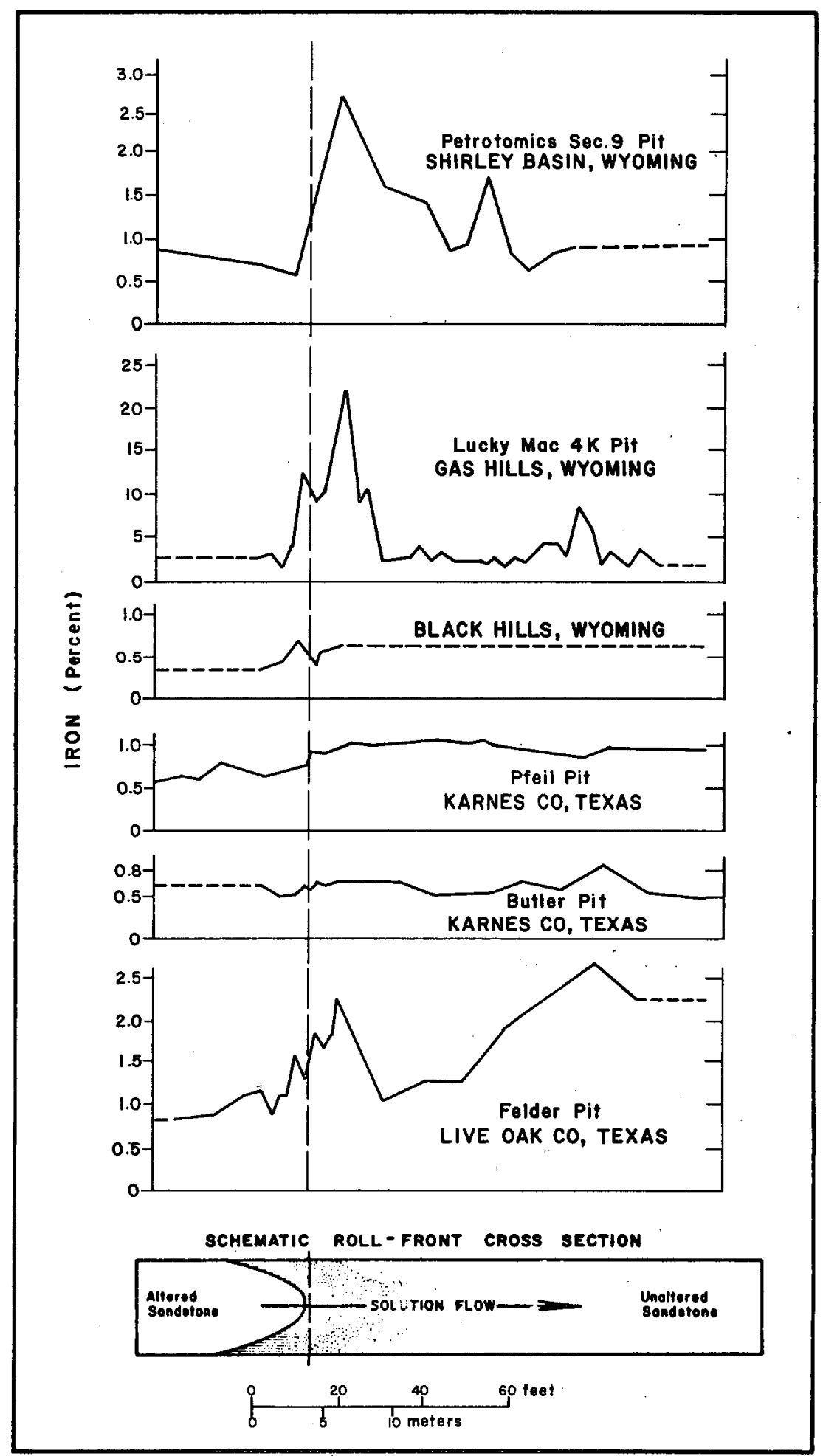

Figure 4u. עIstribution of total iron in roll-type uranium deposits in Wyoming, South Dakota, and Texas (from Harshman, 1974). 


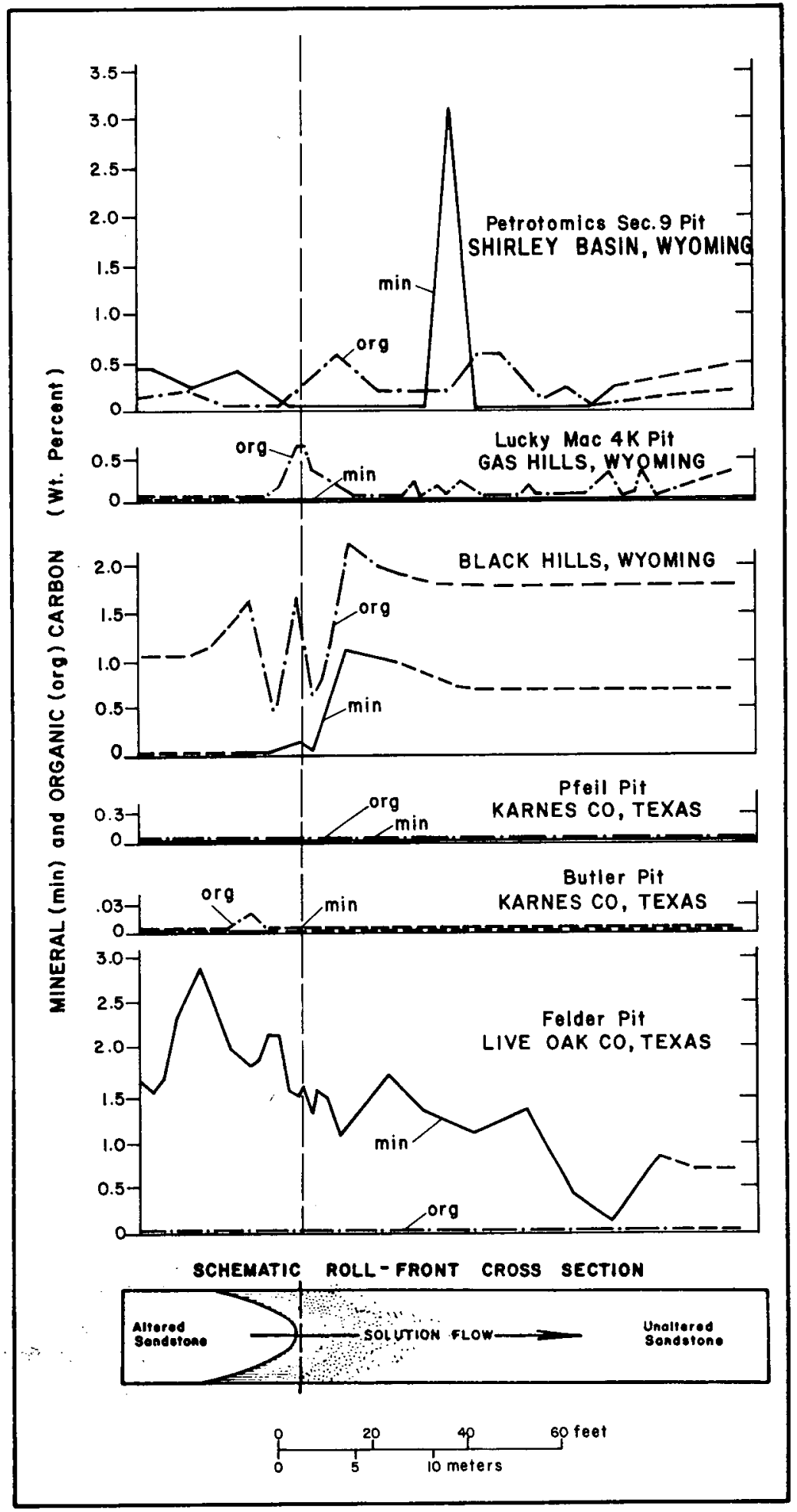

Figure 41. Distribution of mineral (MIN) and organic (ORG) carbon in roll-type uranium deposits in Wyoming, South Dakota, and Texas (from Harshman, 1974). 


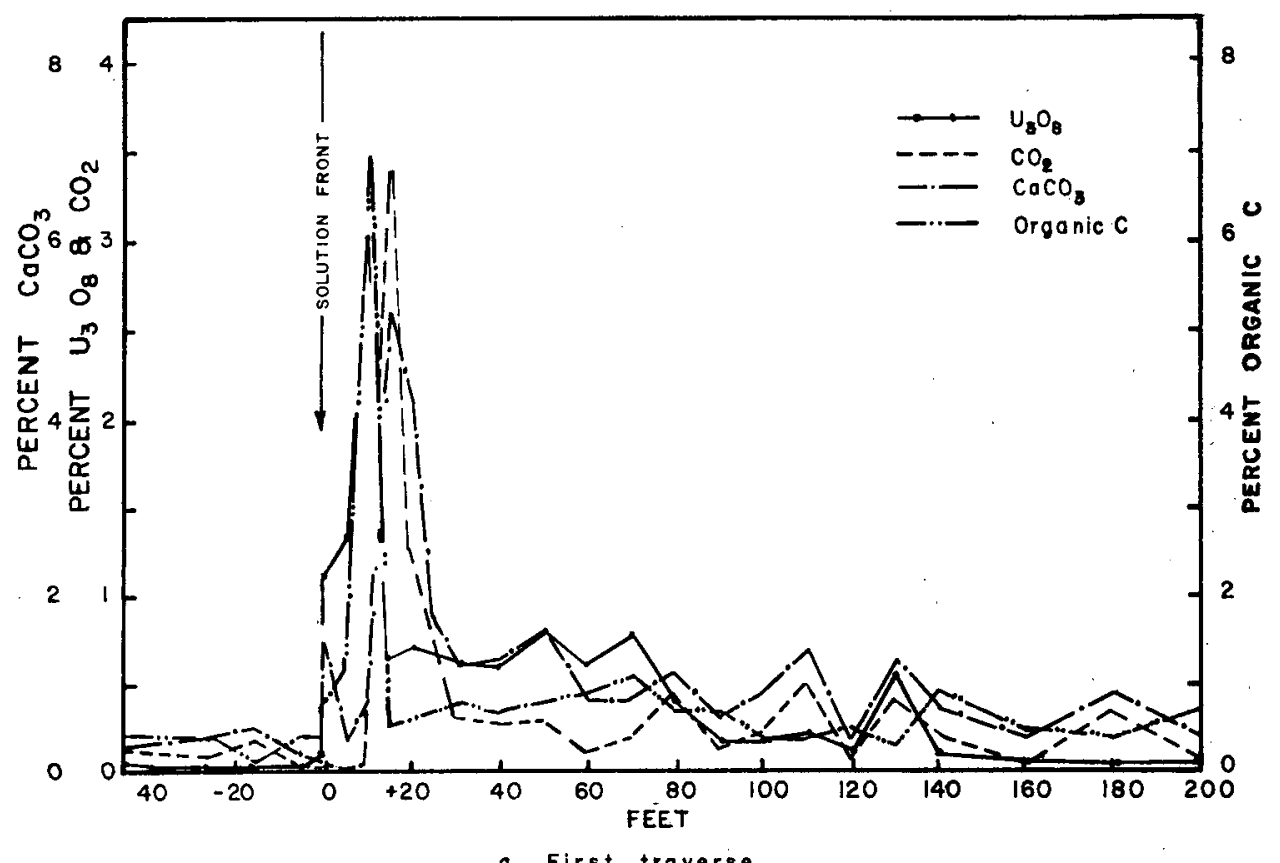

a. First troverse

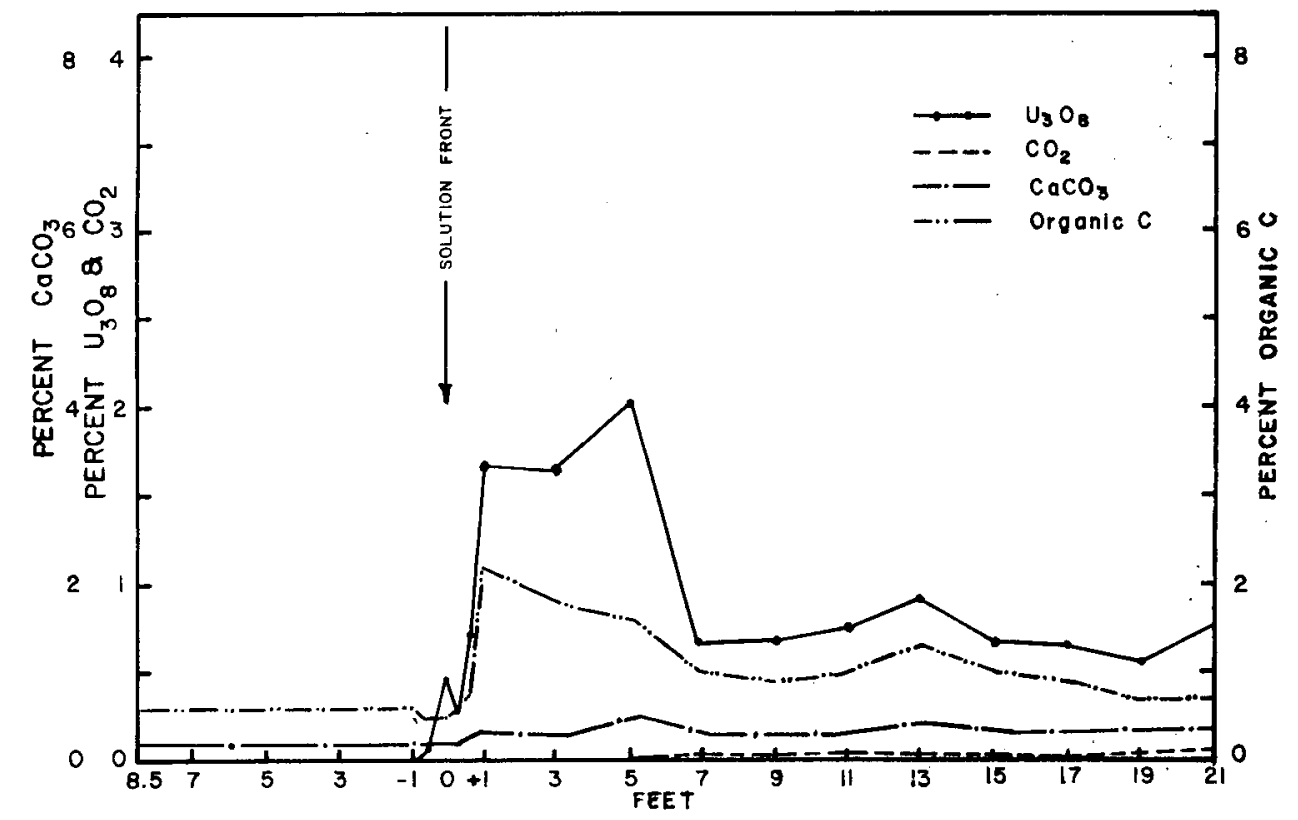

b. Second troverse

Figure 42. Relations among $\mathrm{U}_{3} \mathrm{O}_{8}, \mathrm{CO}_{2}, \mathrm{CaCO}_{3}$ and organic carbon for two traverses across a roll front in the Gas Hills District (from King and Austin, 1966). 
uranium deposits. There is, however, an indication in Figures 41 and 42 that there has been some migration of organic carbon, probably from the altered sandstone, and deposition in the mineralized sandstone along with uranium and associated elements. This possibility needs confirmation because present data are inadequate and the documentation of the dissolution, transport and reprecipitation of organic material in a roll-type system might have important implications for organic dominated systems such as the Grants Mineral Belt.

\section{Sulfate Sulfur}

Sulfate sulfur has been removed from the altered sandstone where it was originally present as gypsum (Fig. 43). It is present in amounts of 1 percent or more in the mineralized sandstone in the Gas Hills and Shirley Basin deposits. Gypsum has been identified in ore from the Shirley Basin and Gas Hills (Files, 1970). A sample of ore from the Shirley Basin containing 3.3 percent sulfate sulfur when leached in distilled water yielded a filtrate saturated in calcium sulfate and high in iron (Harshman, 1974), suggesting that a ferrous sulfate mineral, as yet unidentified, is present in the ore.

\section{Arsenic}

Arsenic is present in amounts of up to about 1 percent, and it correlates well with pyrite in the Gas Hills (Fig. 44). In the Shirley Basin and Black Hills the amounts are generally less than 0.005 percent, and the correlation with pyrite is only fair. Arsenic is slightly higher in altered sandstone than in unaltered sandstone in the Black Hills deposits where it may be associated with hematite and goethite.

\section{Bery11ium}

Beryllium is present in amounts ranging from 1.5 to $5.5 \mathrm{ppm}$ in the Gas Hills and Shirley Basin (Fig. 45). It is associated with uranium in the ore and is below $1.5 \mathrm{ppm}$ in altered and unaltered sandstone.

\section{Copper}

Copper is present in amounts ranging from 10 to $20 \mathrm{ppm}$ (Fig. 46). It has not been deposited with any of the other ore minerals, a surprising fact for an element that is easily reduced. There appears to have been some copper removed from the altered sandstone, but if so it apparently remained in solution and was transported beyond the mineralized area.

\section{Phosphate}

King and Austin (1966), Files (1970), and Harshman (1972), have published data that related high phosphate to high uranium contents in mineralized sandstone in the Gas Hills and Shirley Basin areas. Samples containing 2 or 3 percent uranium may contain as much as 1.0 percent $\mathrm{P}_{2} \mathrm{O}_{5}$, but generally phosphate contents of high-grade samples are less than 0.5 percent. Uranium/phosphate ratios range from 0.02 to about 30 , so the phosphate-uranium relationship is not a direct one. No uranium phosphate mineral has been identified by the three investigators, but Grutt (1957) mentions sandstone cemented with carbonate-fluor-apatite in the Gas Hills. 


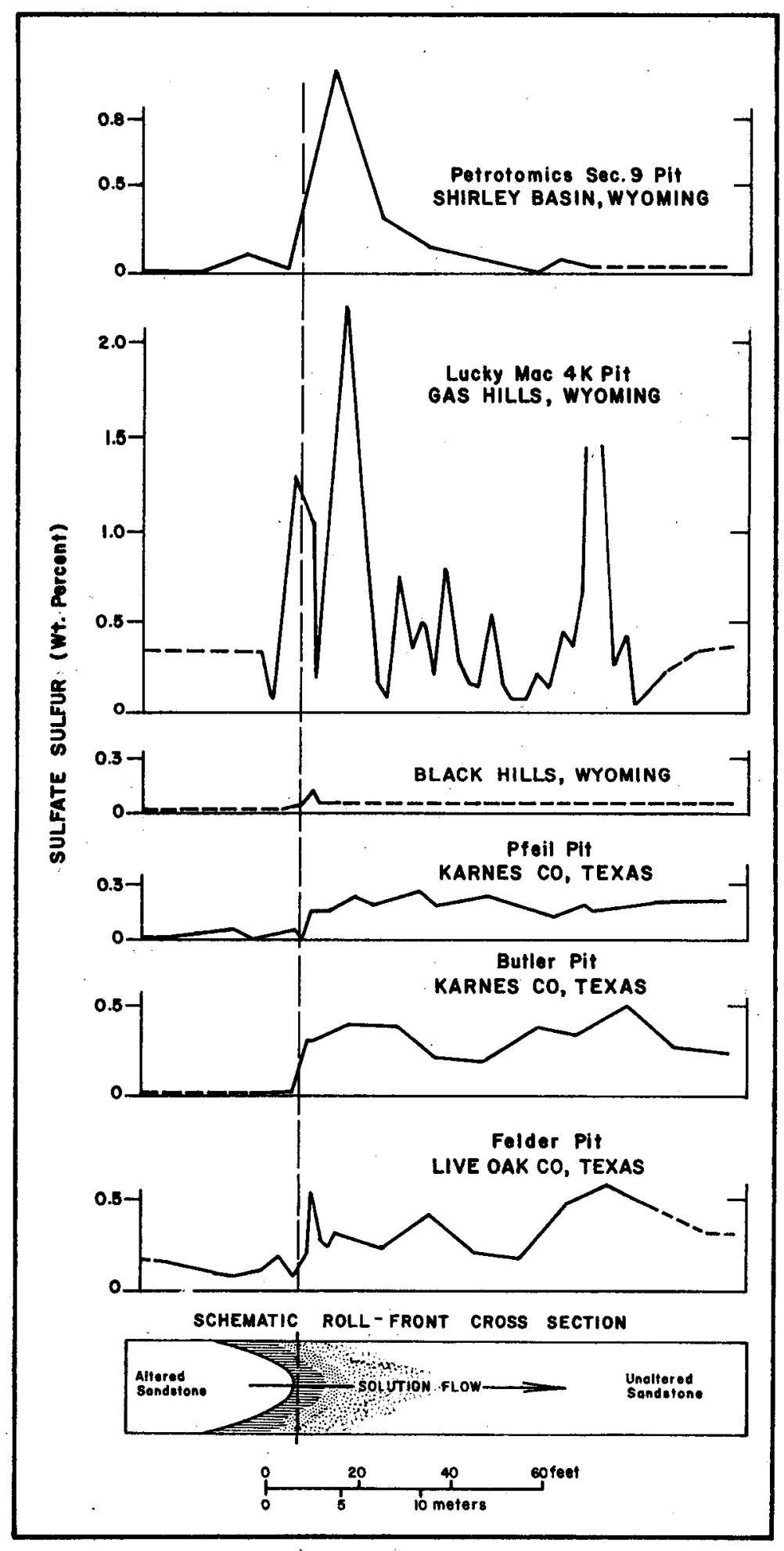

Figure 43. Distribution of sulfate sulfur in roll-type uranium deposits in Wyoming, South Dakota, and Texas (from Harshman, 1974). 


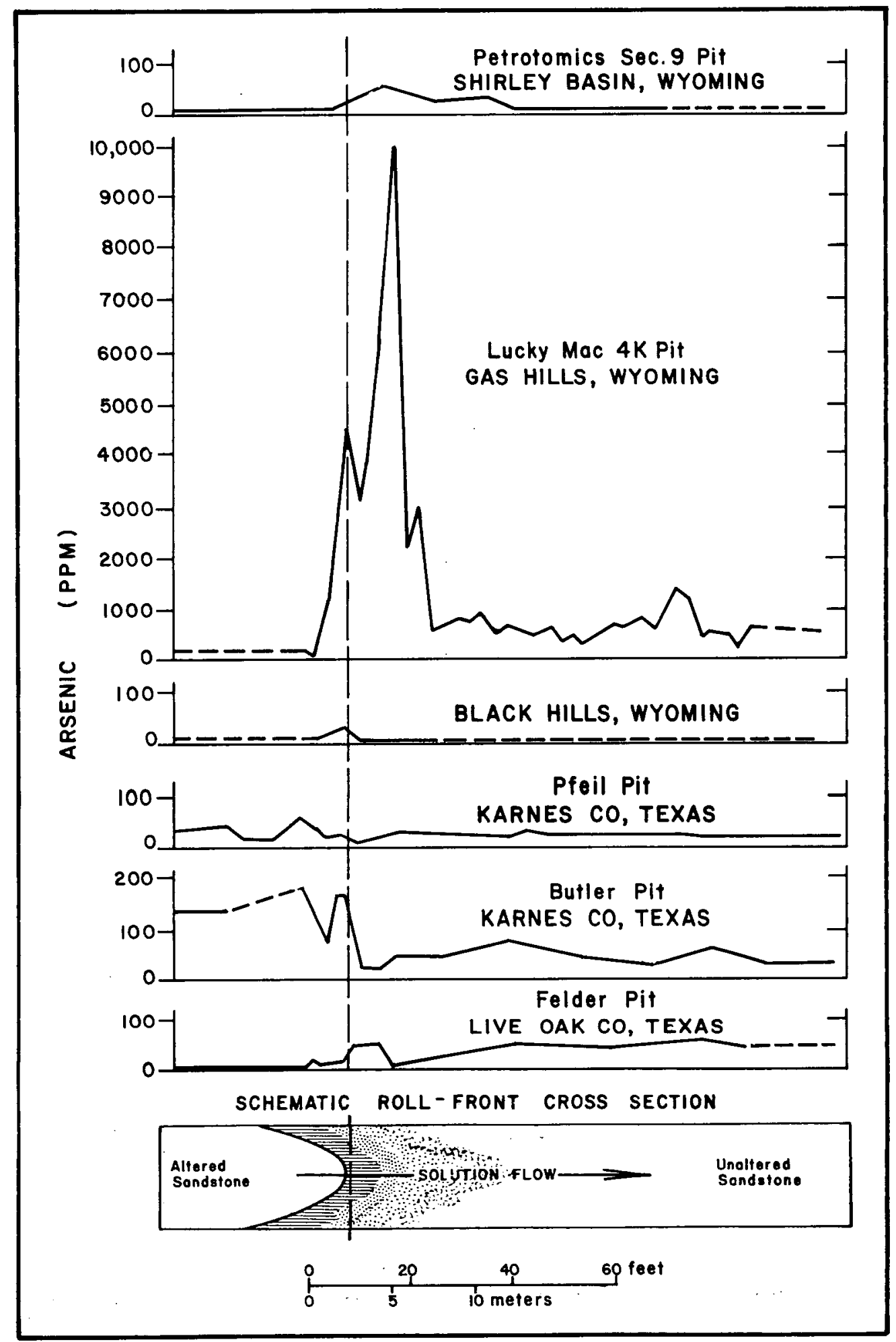

Figure 44. Distribution of arsenic in rol1-type uranium deposits in Wyoming, South Dakota, and Texas (from Harshman, 1974). 


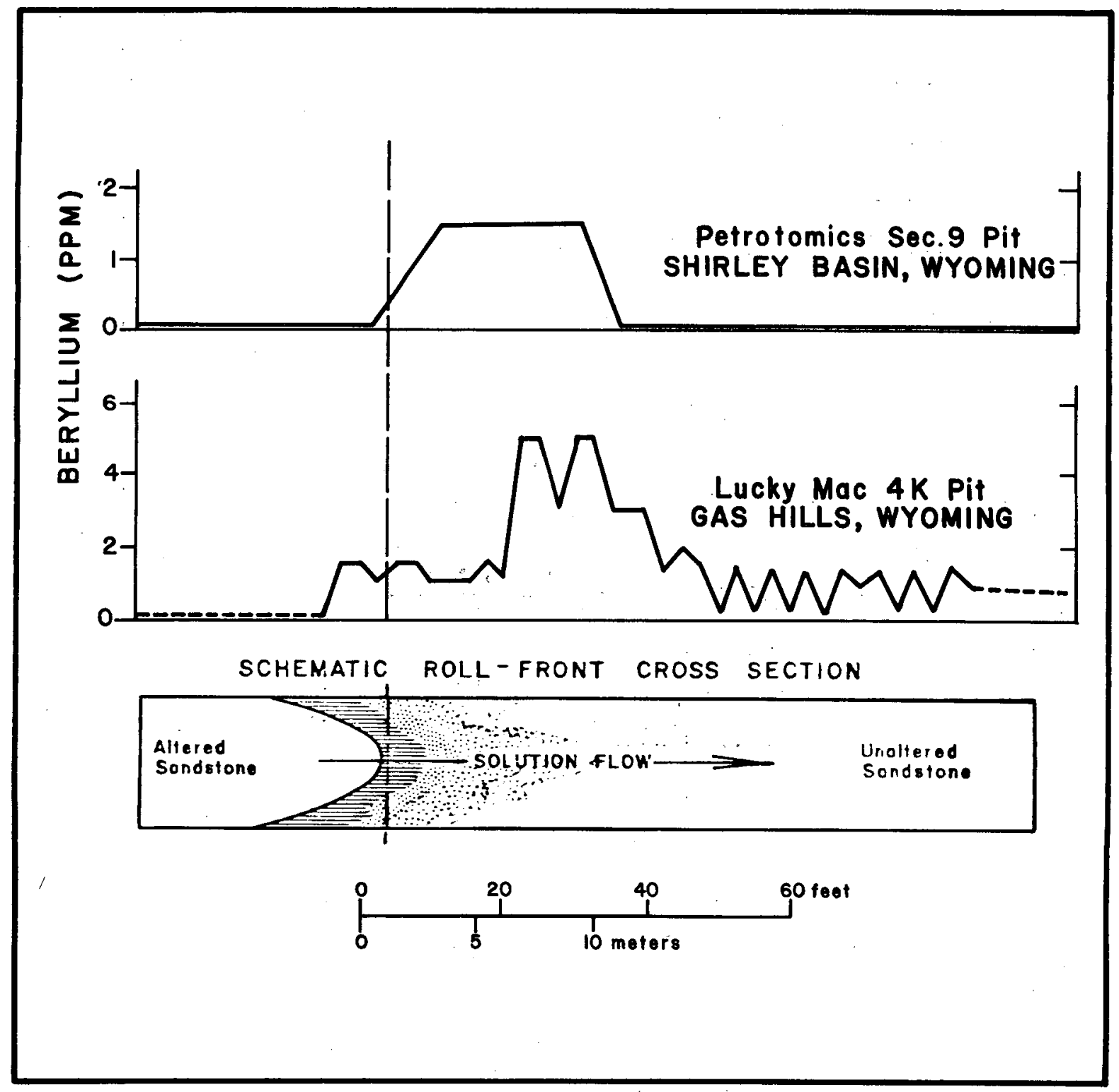

Figure 45. Distribution of beryllium in roll-type uranium deposits in Wyoming, South Dakota, and Texas (from Harshman, 1974). 


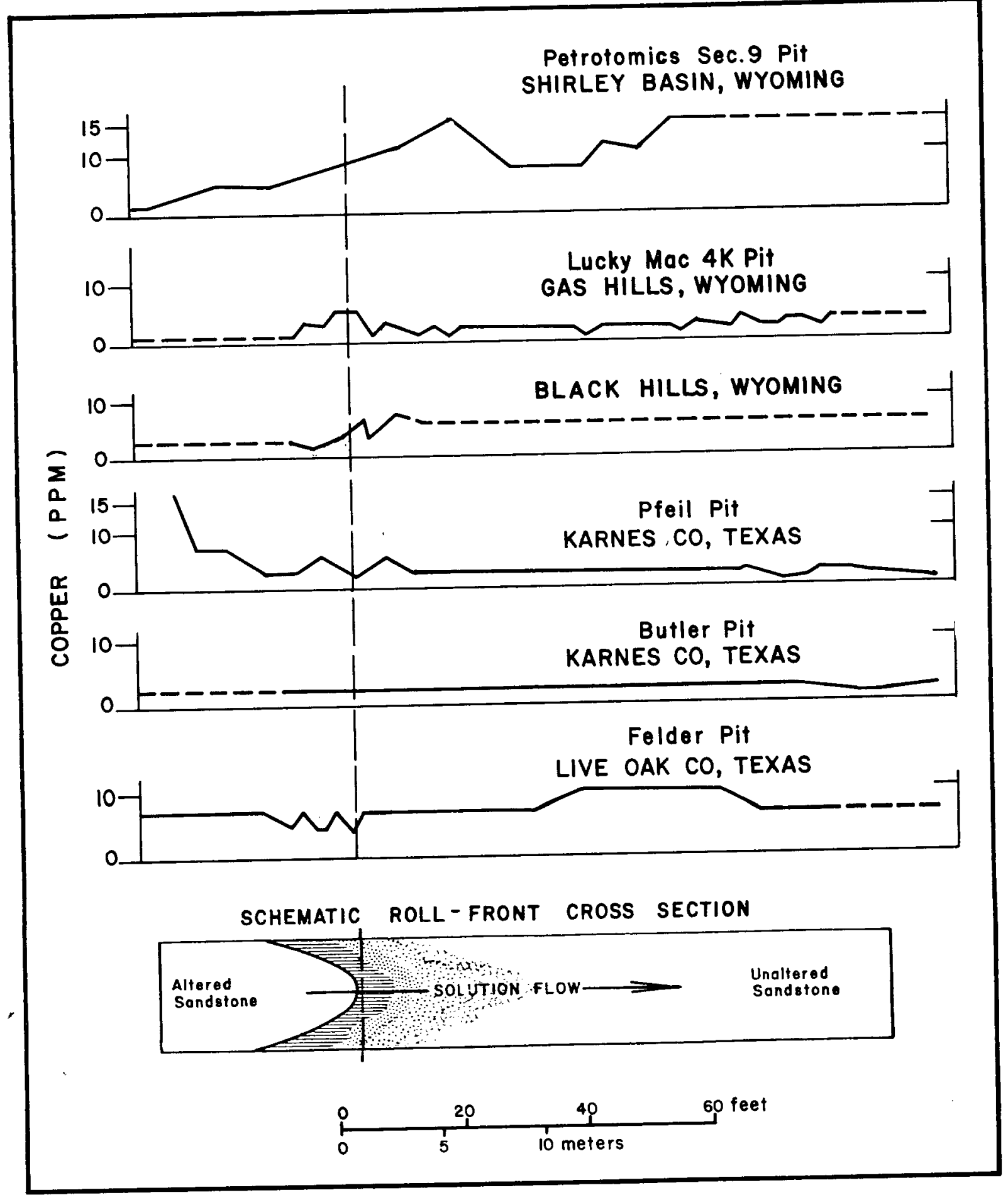

Figure 46. Distribution of copper in rol1-type uranium deposits in Wyoming, South Dakota, and Texas (from Harshman, 1974). 
Figure 47 is a graphic summary of the distribution of selenium, vanadium, molybdenum, uranium, and pyrite in the Shirley Basin, Gas Hills and Texas districts. Also shown are the widths of the zones through which each element or mineral was deposited.

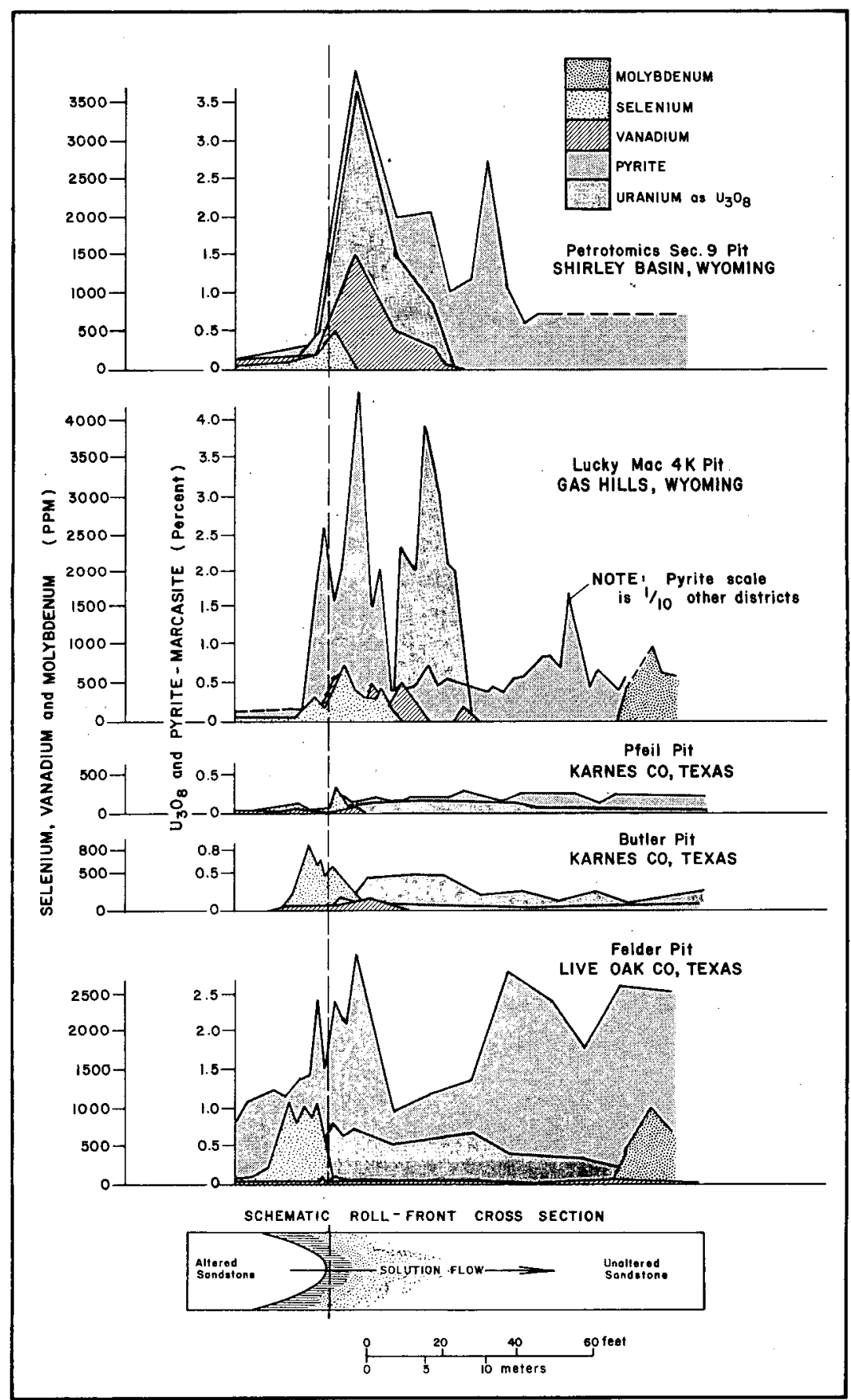

Figure 47. Distribution of selenium, vanadium, molybdenum, uranium, and pyrite in roll-type uranium deposits (from Harshman, 1974). 
This section of the report summarizes and places in proper sequence the events that gave rise to the deposits described in the preceding sections. Of necessity, much of what follows is speculative, but we believe the accumulated laboratory and field data will keep that speculation within reason. As more data become available, the model will change, but until that time it can serve to guide exploration for new deposits and to assess the uranium potential of unexplored areas.

The need for "ground preparation" is as essential for uranium deposits in sedimentary rocks as it is for other metals in other hosts, for without it there would be no deposits. In the Black Hills area, ground preparation, leading to organic-rich permeable sediments, began with Late Jurassic and Early Cretaceous uplift and erosion of areas southeast and southwest of the present Black Hills. The source areas apparently were composed of Jurassic and older sedimentary rocks as there is an almost complete lack of minerals of igneous or metamorphic origin in the Inyan Kara host rocks. The material in the lower part of the Inyan Kara group was derived principally from the southwest and some volcanic material was included, apparently from activity in the southwest source area. Moderate renewed uplift continued through Inyan Kara time, maintaining the vigor of the northwesterly flowing streams, but by the middle of the period the principal source of clastic material shifted from the southwest to the southeast. Climate, as indicated by fossil plants and spores, was hot and humid; tropical to subtropical vegetation was abundant. Host rocks were in place by the end of Inyan Kara time when marine conditions returned to the area. Host rocks consist of fluvial and marginal marine channel sandstones, interbedded and intertonguing with siltstones and mudstones, all incorporating considerable carbonaceous material. Reducing conditions and diagenic pyrite developed in the sediments shortly after their deposition, conditions that were to be maintained by deep burial until the early Tertiary period of uranium mineralization many million years later.

The model for the uranium deposits in the Wyoming basins begins with the Laramide orogeny when the mountain ranges and intervening basins as we know them today came into being. Uplift increased the vigor of the streams and by Late Paleocene or early Eocene they had stripped most of the sediments from the flanks of the ranges and exposed their granitic cores. Large wet alluvial fans were deposited by braided streams high on the basin flanks and bed-load streams deposited coarse arkosic sediment in the lower reaches of the basins. The climate was tropical to semitropical--hot, moist, with periods of considerable rainfall interspersed with dryer periods. The uplands and basins supported a dense growth of vegetation and this organic material was incorporated in the sediments. Deposition was rapid, water tables in the lower parts of the basin were high, and thus reducing conditions accompanied by deposition of diagenic pyrite were maintained in the sediments. Periods of erosion followed periods of deposition and there was considerable lateral migration of stream channe1s.

Weathering and erosion of the granite cores of the mountain ranges may have released uranium to vadose waters and some of it may have been carried by ground water and deposited in the lignitic material in the reduced basin fill. 
Much of it was probably transported from the basins in surface streamflow. With continued erosion of the uplands and filling of the basins, stream gradients decreased and the coarse-grained host sediments were covered with less permeable siltstones and claystones. Periods of gentle uplift, erosion and deposition continued into middle and upper Eocene time when volcanic activity started in the Absaroka and Rattlesnake Hills areas of western and central Wyoming and in the Black Hills region of South Dakota. Fluvial and lacustrine sedimentation predominated during this period and considerable volcanic ash was distributed through the arkosic material derived from the cores of the uplifts.

A period of extensive erosion at the end of Eocene time removed the Middle and Upper Eocene (Wagon Bed) rocks from the central part of the Shirley Basin and the Crooks Gap-Great Divide Basin area, and cut two large channels through them in Beaver Divide on the south edge of the Gas Hills district. If rocks of Middle and Upper Eocene age were ever present in the Powder River Basin area, which is doubtful, they were removed by erosion.

The Paleocene and Eocene were periods of uplift and erosion in the Black Hills area and the large amount of sediment eroded from the flanks of the uplift was apparently transported out of the area by westerly and northerly flowing streams. The long period from Middle Cretaceous to Upper Eocene was important in the sequence of events that ended with formation of the Black Hills deposits, even though ore-forming processes were not active during that period. Deep burial preserved the reducing environment in the Inyan Kara host rocks so necessary for subsequent mineralization, and uplift in Laramide time started the hydrologic cycle that stripped the thick section of impermeable rocks that overlay the Inyan Kara, exposed their truncated edges, and produce the gentle basinward dip essential to the flow of the mineralizing solutions.

The tuffaceous White River Formation of Oligocene age was deposited on the eroded surface of the Wagon Bed rocks or on beveled surface of the Early Eocene rocks where the Wagon Bed was missing. The basal White River contains sandstone and conglomerate in some areas indicating at least local uplift of the ranges in Early 0ligocene time. Tuffaceous material from the Absaroka volcanic field in northwestern Wyoming was admixed with locally derived arkosic material eroded from the uplands. Heavy ash falls early in white River time gave rise to several relatively pure tuff beds in the lower part of the White River Formation.

At about this time, oxygenated waters entered the truncated edges of the Inyan Kara host rocks in the Black Hills and the exposed and/or truncated edges of the Lower Eocene rocks in the Wyoming Basin. This water originated in the granitic cores and flanking metamorphic and sedimentary rocks of the mountain ranges updip from the host rock outcrops (Fig. 48), and carried uranium and associated elements probably derived in part from the granite and in part from the recently deposited tuffaceous White River Formation. The oxidizing solution entered the reduced host rock high on the flank of the basin and at first it was out of equilibrium with the reducing environment of the host rock through which it moved. By oxidation of the host rock components, particularly pyrite and carbonaceous material, conditions approximating equilibrium were established in an oxidized zone at and somewhat downstream from the area of ingress of the mineral-bearing solutions. This zone was at first very 


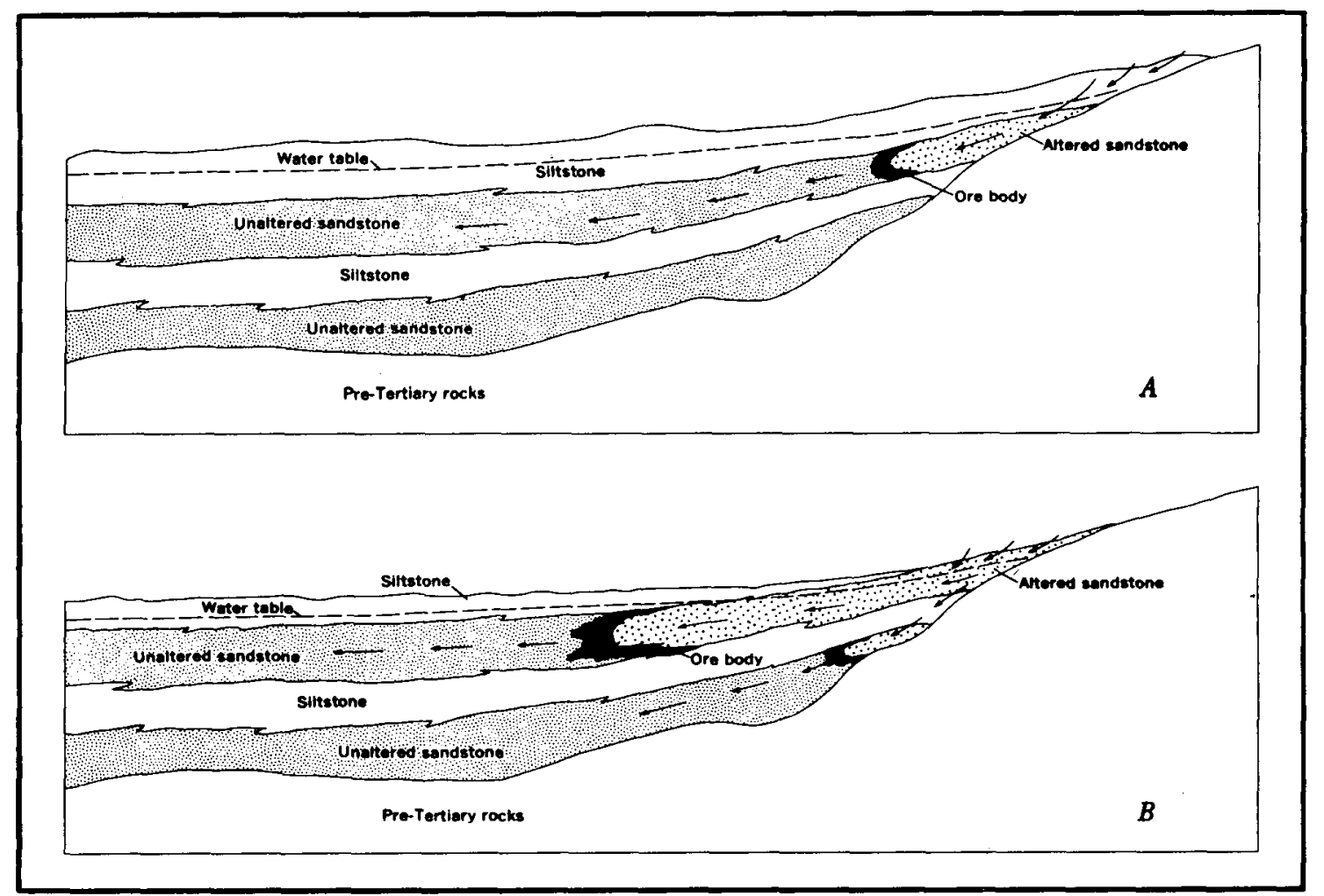

Figure 48. Possible paths for circulation of mineralizing solutions in the Wyoming basins. Arrows indicate direction of ground water flow (from Harshman, 1972).

smal1, but it expanded in the direction of ground water flow and an interface was established between oxidizing conditions in the updip part of the host rocks and reducing conditions in the downdip part. More correctly, several interfaces were established, the position of each being dependent on the combined effect of. Eh and $\mathrm{pH}$ changes on the solubility of the various elements being transported in the solution. The interface most generally discussed is that for oxidized and reduced forms of iron, but in almost all rol1-type uranium deposits there are recognizable interfaces for selenium, molybdenum, vanadium, uranium and other elements. Deposition of each element carried in solution seems to be most pronounced at the redox interface for that element, decreasing rapidly as the solution moved beyond that interface into the reduced zone.

Any mineralized zone established early in the cycle just described would be small and relatively low-grade. It would migrate in the direction of ground water flow, generally downdip, by oxidation and solution on the updip side of the mineralized zone and reduction and redeposition on the downdip side. A continuous extrinsic supply of uranium and associated elements in the mineralizing solution passing through the zone of deposition would cause the mineralized zone to increase in both grade and size and to eventually reach the magnitude of the present-day deposits. 
Most authors consider Eh or oxidation capacity of the system to be the dominant factor in dissolution, migration, and redeposition of the mineral components in roll-type deposits. The Eh-pH diagrams of Garrels and Christ (1965), and Hostetler and Garrels (1962) illustrate this conclusion, but also show that $\mathrm{pH}$ changes are important to the dissolution and precipitation of most minerals. Figure 49 shows the postulated path of a unit of solution, within an Eh-pH diagram, as the solution moves from the oxidizing environment of the altered sandstone through the roll front and into the unaltered sandstone.

Ground water collected in the U.S.S.R. below the permanent water table along traverses extending from altered sandstone through ore and into unaltered sandstone (Lisitsin and Kuznetsova, 1967) confirmed Eh and $\mathrm{pH}$ conditions almost identical with those shown in Figure 49. If Eh is the principal control of deposition and if th decreases downdip away from the altered tongue as shown in Figure 49, then elements requiring the lowest Eh for the reduction should be deposited at the greatest distance from the edge of the altered tongue (redox interface for iron). Figure 50 is a composite Eh-pH diagram based on data by Garrels (1960), Garrels and Christ (1965) Hostetler and Garre1s (1962), Lakin (1961), Lisitsin (1969), and Hansuld (1966). It shows the equilibrium boundaries between the relatively soluble and insoluble forms of selenium, vanadium, uranium, and molybdenum and between pyrite and two ferric iron compound, expressed for conditions of temperature, pressure, and solution composition, and concentration that approximate the likely but somewhat simplified conditions in the mineral-bearing solutions. If one assumes a starting solution $\mathrm{pH}$ of 7.5 , then decreases its Eh from +300 to $-300 \mathrm{mv}$ near the roll front, at constant $\mathrm{pH}$, the diagram predicts that the path of solution Eh will intersect the element boundaries in the same order that they are actually found in roll-type deposits (Fig. 47). The diagram also shows that a one or two unit decrease in $\mathrm{pH}$ concurrent with decreasing Eh will not change the sequence of deposition.

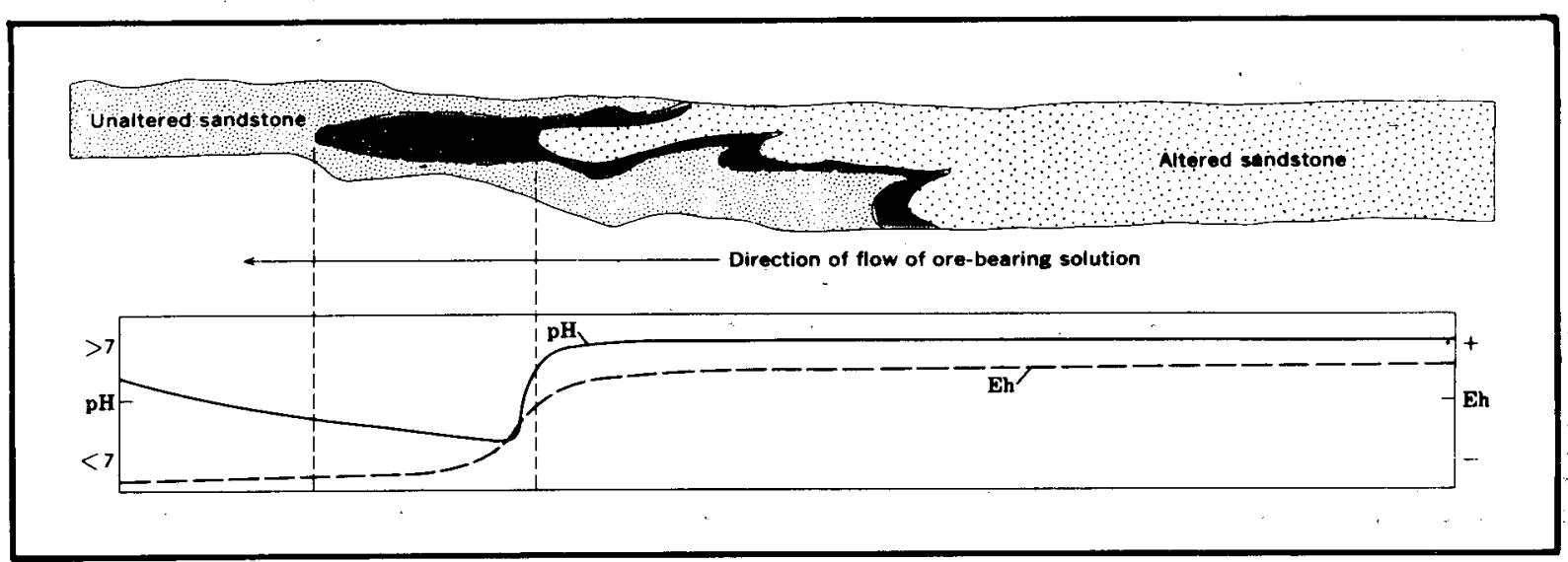

Figure 49. Postulated $\mathrm{Eh}$ and $\mathrm{pH}$ conditions during transportation and deposition of uranium and other elements in the Wyoming basins (from Harshman, 1970). 


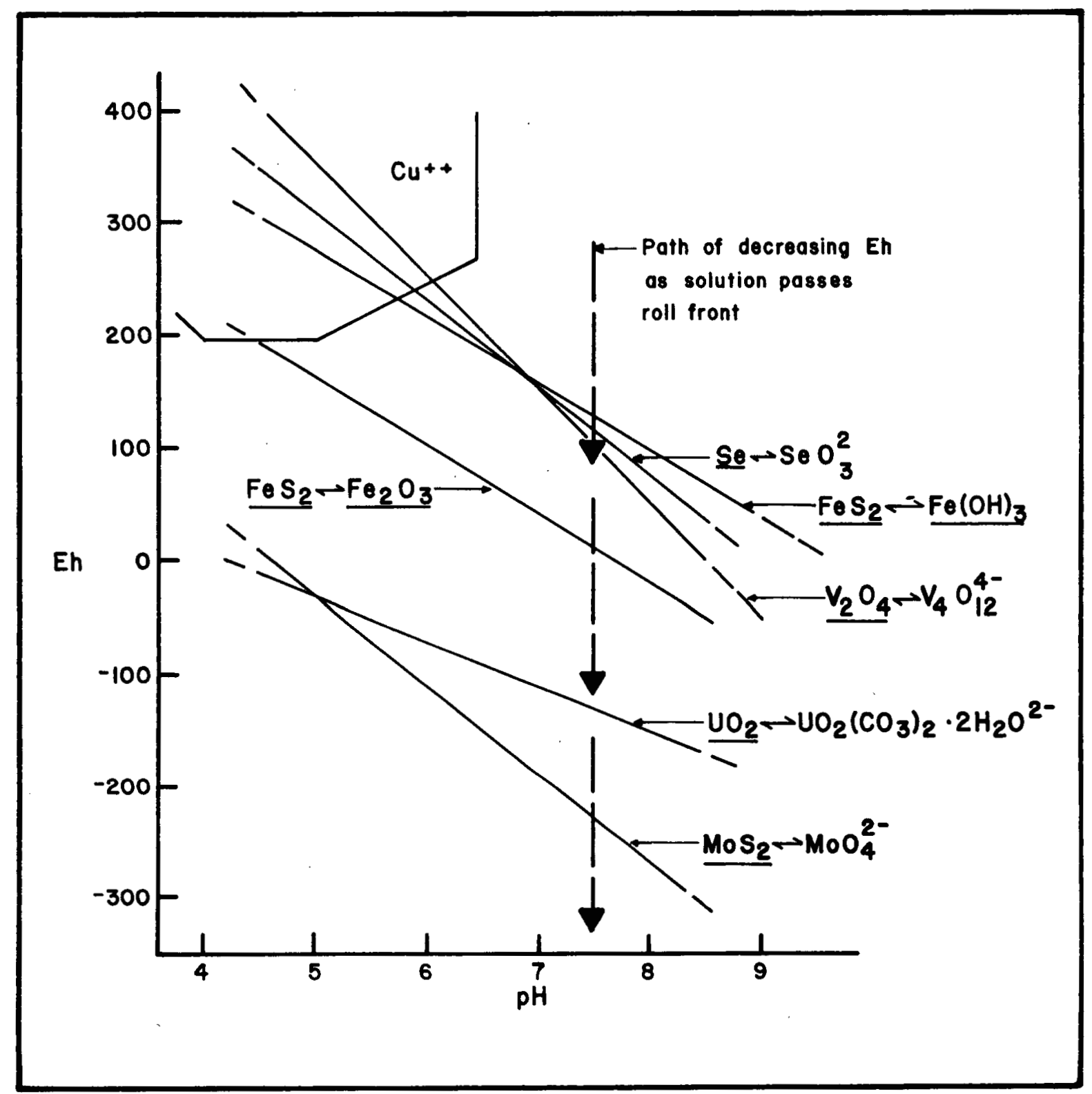

Figure 50. Composite Eh-pH diagram for the principal elements in rol1-type uranium deposits, and for copper. Solid phases are underlined (from Harshman, 1974). 
Roll-type uranium deposits range from narrow and high-grade (Shirley Basin, Gas Hills) to wide and relatively low-grade (Great Divide Basin), and there appears to be an inverse relation of grade to width. Several factors may be responsible, all somewhat related to the reducing capacity of the sandstone downdip from the redox interface for iron. The lower-grade wider deposits frequently occur in sandstones with small amounts of carbonaceous plant remains and/or small amounts of pyrite in the unaltered host rock. This contrasts with larger amounts of carbonaceous debris and/or pyrite associated with the higher-grade relatively narrow deposits. This fact suggests that the reduction potential gradient in the zone of deposition, due either to biogenic or non-biogenic processes, may have been steep in the case of narrow high-grade deposits in which case rapid dumping of transported elements would occur. If the gradient were relatively flat, deposition of transported elements would be slow and extended over a considerable distance resulting in broad relatively low-grade deposits. Other factors that might affect the Eh gradient are (a) the rate of flow of the mineral-bearing solution through the reduced sandstone which could compress or extend the zone through which deposition takes place, and (b) the availability of the reductant for reaction with the mineral-bearing solutions, which might be disseminated through a permeable sandstone or contained in relatively impermeable clays in or bounding the host rock.

The edge of the oxidized tongue is not everywhere uniformly mineralized, and orebodies are dispersed at irregular intervals along it. The best orebodies seem to be where there are changes in strike of the tongue's edge where the direction of flow of the solutions was nearly perpendicular to the edge of the tongue. A good example can be seen in Figure 10 where the best orebodies are at such changes in strike. Local concentrations of carbonaceous material and/or pyrite may produce very reducing conditions in local areas and thus cause increased deposition in those areas.

The accretion of mineral in the host sandstone is probably most efficient in gently-dipping beds for even if the beds that overlie the host sandstones are relatively impermeable, there can be considerable loss of water from steeply dipping very permeable beds into an overlying much less permeable bed. Note in Figure 51 that ground water tends to move from the aquifer into and across the overlying aquitard. As the dip of a host sandstone increases, therefore,

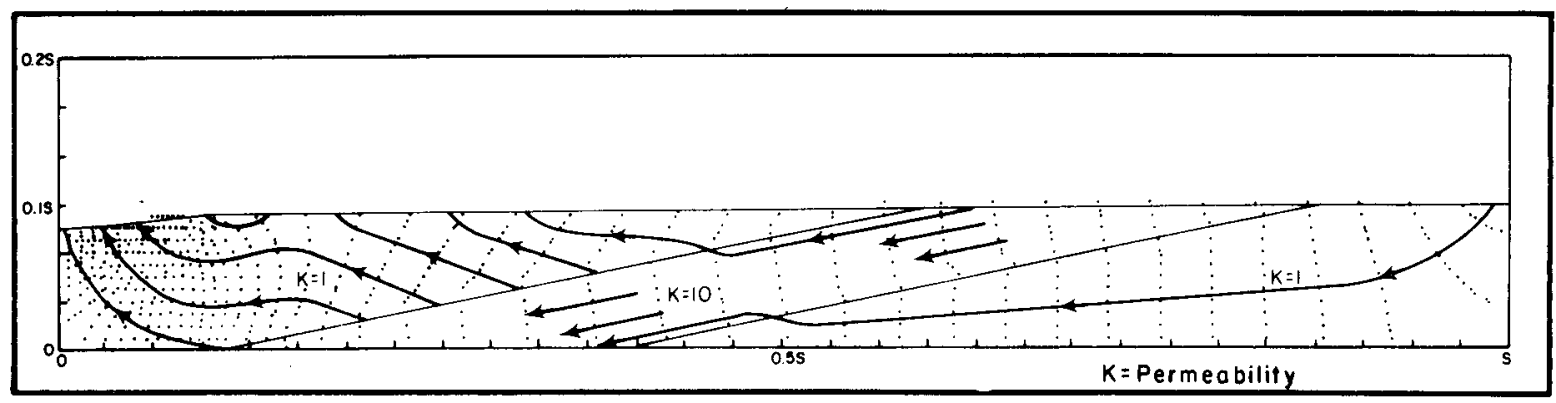

Figure 51. Hypothetical ground water flow paths for steeply-dipping high permeability unit between two low permeability units (modified from Kreitler, 1979). 
the loss of ground water into the overlying rocks retards and ultimately arrests the propagation of the roll front. In gently-dipping permeable beds there is some flow from the overlying less permeable beds into the more permeable beds as shown in Figure 52, and the propagation of the roll front may even be enhanced.

The processes described above continue downdip in the host rocks for distances of 5 to 12 miles and to depths of several hundred feet below the ground surface. As long as oxygen and slightly mineral-bearing water is supplied to the roll front (redox interface), deposits will accumulate at a rate governed by several factors including supply of oxygen, amount of pyrite and/or carbonaceous material, biological or abiological reduction of sulfur, rate of flow of the mineral-bearing solution, and possibly the length of the altered tongue. The process stops when the hydrologic system changes and oxygenated water is no longer supplied to the roll front, the reduced zone is destroyed by oxidation, or the oxygenated water entering the host sandstone at or near the outcrop or paleo-outcrop becomes so diluted by reducing water entering the host from overlying sediments. The importance of dissolved oxygen in the formation of roll-type uranium deposits is discussed by Granger and Warren (1979).

While the deposits were forming, deposition of the White River Formation (Oligocene) continued over large parts of Wyoming, North and South Dakota, and Nebraska (Fig. 4). It accumulated to thicknesses of 500 or more feet in much of the area. Deposition of the Arikaree Formation of Miocene age and the Ogallala Formation of Pliocene age followed and the deposits were buried under many hundred to several thousand feet of arkosic, tuffaceous rock. This burial served to protect the uranium deposits from destruction by erosion and attack by surface waters.

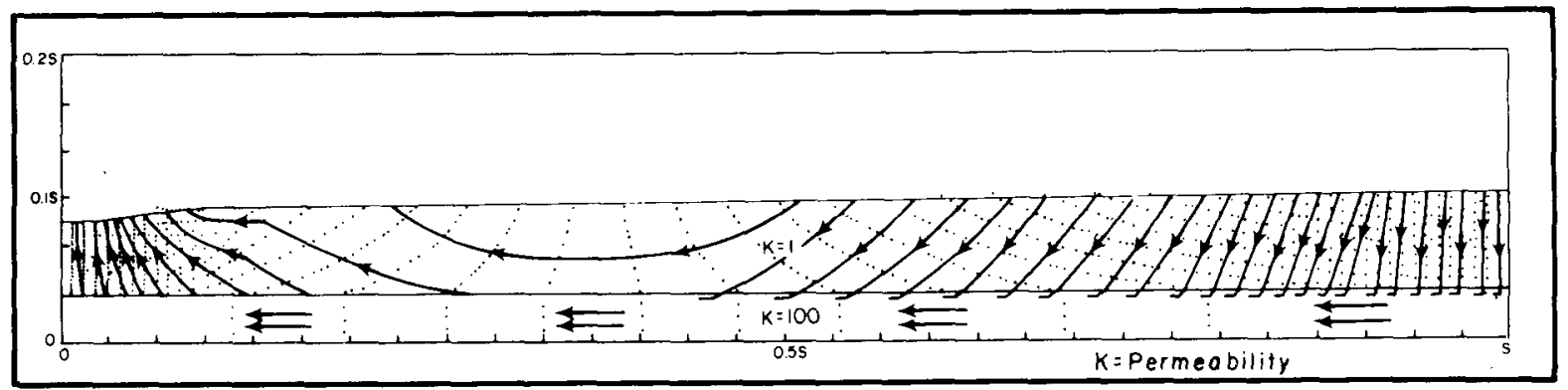

Figure 52. Hypothetical ground water flow paths for gently-dipping high permeability unit overlain by low permeability unit (modified from Kreitler, 1979). 
Throughout this report we have considered processes that led to what might be termed "primary" roll-type deposits; that is, those deposits that originated at the outcrop or paleo-outcrop moved downdip by solution, migration, and redeposition, and whose further development was arrested by an interruption in some critical phase of the process.

Post-depositional uplift and erosion can expose the primary deposits for remobilization and redeposition of the uranium. Vanadium and other elements capable of forming uranium minerals that are relatively insoluble under near surface oxidized conditions are not present in significant amounts in the Wyoming basins, and once uranium is taken into solution it will pass out of the basin unless it enters a reducing environment similar to that responsible for the primary deposits. If the post-depositional flow system differs greatly from the depositional system destruction of the deposit is probable.

The Powder River Basin and the Black Hills are examples of districts in which the post-depositional, and in each case the recent flow systems, approximate the primary depositional system in direction of flow, character of the water, volume of flow, hydraulic gradient, and rate of flow. In both districts the altered sandstone comprises several mineralogically different zones near the edges of the altered tongues. These zoned altered sandstone tongues contrast with the unzoned tongues in the Shirley Basin and Gas Hills where the postdepositional and recent flow systems do not correspond with those extant at the time of primary deposition. The zoned edges are thought to represent oxidation related to more recent periods of roll-front advance and redistribution of mineralization.

Kenneth Ludwig (personal communication, 1980), geochronologist for the U.S. Geological Survey, recently analyzed four samples of ore and two separates "of nearly pure pitchblende-coffinite intergrowths" from the Highland mine in the southern part of the Powder River Basin. He concludes "that the true time of mineralization of these particular samples is almost certainly in the range of $2.5+1.5 \mathrm{~m} . \mathrm{y} . "$ He does not know how this young age relates to the rest of the mineralization in the Highland mine or to the deposits in the southern part of the basin, due to the restrictive nature of the sampling, nor does he "rule out the possibility that the sampled roll front could have resulted from late redistribution of much older orebodies." The geologic history of central Wyoming suggests that conditions favorable for uranium deposition were extant in all the Wyoming basins at about the same time (Middle Eocene to Late Oligocene). This very young age adds credence to the belief that the zoned altered tongues in the Powder River Basin, and probably in the Black Hills, result from redistribution of uranium from much older primary roll-type deposits.

Recent redistribution of uranium will cause considerable disequilibrium between $\mathrm{eU}$, as measured by gamma-ray probes and actual uranium content as determined chemically. It requires about 250,000 years for uranium to reach approximate equilibrium with its daughter products and any "new" uranium that has not had time to equilibrate with its daughters will contain more uranium than indicated by ganma-ray devices. In the Gas Hills area uranium ore, apparently redistributed very recently from older deposits, has been discovered 
which has almost no gamma-ray activity; it has appropriately been called "no count ore." Such ore may be present in any mining district subject to recent redistribution of old deposits.

Under certain conditions re-reduction of the oxidized tongue may occur. If the supply of oxygenated water from the zone of recharge greatly decreases, semi-stagnation of water in the oxidized host rock may allow reducing conditions to again prevail. Reducing conditions can be re-established by ingress of reducing waters from adjacent carbonaceous fine-grained rocks or by permeation of the sandstone host by reductants such as sour gas. Some reduction of the oxidized tongues in the Weld County deposits may be related to reduction by sour gas, for cores of some drill holes in the area have a strong odor of $\mathrm{H}_{2} \mathrm{~S}$. 


\title{
RECOGNITION CRITERIA
}

\author{
Introduction
}

The geologic characteristics of important domestic roll-type deposits have been reviewed and discussed in the context of ore-forming processes in the preceding sections of this report. We now proceed to identify those geologic characteristics related to these deposits that we feel are most diagnostic for the presence or absence of deposits in unexplored areas. The geologic characteristics selected, including geophysical and geochemical observations, are referred to as recognition criteria, and have been shown to be related in some significant way to this type of deposit. These recognition criteria should be useful in resource studies and exploration for estimating the geologic favorability of an area of study for the occurrence of a roll-type deposit.

The selection, definition, and ranking of recognition criteria are routinely performed by the expert geologist "in his head". The material presented in this section and in the Appendix, is not intended for the "expert" but for those geologists involved in exploration or resource studies who are still developing their data bases and interpretations. Nor is this material presented as a "cookbook" to be perfunctorily applied to prospective areas. Considerable geologic judgement is required in the use of the recognition criteria, and inexperienced geologists will encounter much difficulty. The criteria are merely guides to be used by trained geologists as they develop their evaluations of unexplored areas for purposes of exploration or resource studies.

To be useful in resource studies or exploration, recognition criteria are chosen so that: (a) when they are present or favorable, the chances of a deposit being present are significantly increased, i.e. they are important "good news"; or (b) when they are absent, or unfayorable, the chances of a deposit being present are significantly decreased, i.e., the negative criteria are important "bad news". Some recognition criteria have both attributes and are thus particularly useful. By using only criteria that significantly affect the likelihood of a deposit being present or absent, one avoids the distraction of including geological observations which are too ubiquitous or undiagnostic to be useful guides to the favorability of an area.

Considerable subjectivity is involved in the selection, definition, and use of the recognition criteria. Because geologic observations do not lend themselves to rigorous numerical treatment, the use of such data unavoidably involves subjective judgement. In our opinion, it is far better to use the data and the judgements, carefully documenting where and how subjectivity has been used, than simply to leave the reader to make the most of geologic information such as was presented in the preceding sections of this report. In the following paragraphs, therefore, we subjectively select and define those criteria which, based upon our experiences and the data contained in the preceding sections of this report, we consider to be most useful for evaluating areas for roll-type deposits. We make no pretense that these are the only criteria and definitions that could have been chosen; they are simply the best ones we were able to devise. The reader may prefer other criteria and/or 
other definitions which, if they reflect geologic facts, may improve our 1 ist. We acknowledge that such improvements will be needed, and earnestly solicit constructive comments and contributions. Only through a consensus of careful observations and informed opinions will the criteria become reliable and useful.

Recognition criteria may be defined so that they are general or specific. For example, permeability might be chosen as a criterion, and defined to incorporate observations on relevant geologic characteristics, such as sorting, rounding, and sphericity. Conversely, each of these could be chosen as a criterion. For simplicity, we prefer to lump criteria, and therefore, have subdivided them only as far as seem necessary to avoid ambiguity and to identify the most important geologic observations. Here again, subjective judgment and personal preference enter the process.

The detail or scale of each recognition criterion deserves special mention. As exploration and resource studies are conducted on areas of vastly different size and degree of geologic definition, it is appropriate to include recognition criteria that range from regional in scale (i.e., "regional tectonic setting", "uranium content of basement rocks", etc.) to local (i.e., "alteration in the sandstone", "color of interbedded shales", etc.). We have attempted to do this in the accompanying criteria, but some readers may consider certain criteria too general or too detailed to be useful, or may wish to include criteria yet more general or more specific. These options, where supported by geologic data, may improve the list of recognition criteria.

In Figure 53 the criteria we have selected for the roll-type deposits are arranged by scale of observation, proceeding from the broadest and most regional on the left to the most local on the right. The reader will note that the criteria also are arranged in a hierarchical format with the more general criteria, located at the top of the diagram, progressively subdivided into more detailed "modifying" criteria toward the bottom of the recognition criteria net. This format, patterned after Hart, Duda and Einaudi (1978), permits the lowest level criteria (terminal criteria), which are based on field observations, to be combined to evaluate the favorability of the higher levei criteria above them. In the evaluation of an area this combining process continues up through the recognition criteria net until the favorability of the area of study for a roll-type deposit is determined. A rigorous method for combining information on the criteria has been presented by Hart, Duda and Einaudi (1978) and a specific application developed for roll-type deposits by Rackley (Gaschnig, 1980). In the Appendix we present a much-simplified method for combining geologic observations to reach favorability estimates. The reader is cautioned that the individual criteria are used only to establish the favorability of intermediate level criteria. The ultimate favorability estimate for a roll-type deposit is the composite effect of many criteria and it is not necessarily equivalent to the probability of a deposit being present as will be discussed in the Appendix.

With recognition criteria identified and organized as in Figure 53, it is now possible to geologically define each criteria and establish its relative importance in determining the favorability of the criteria above it in the net. 


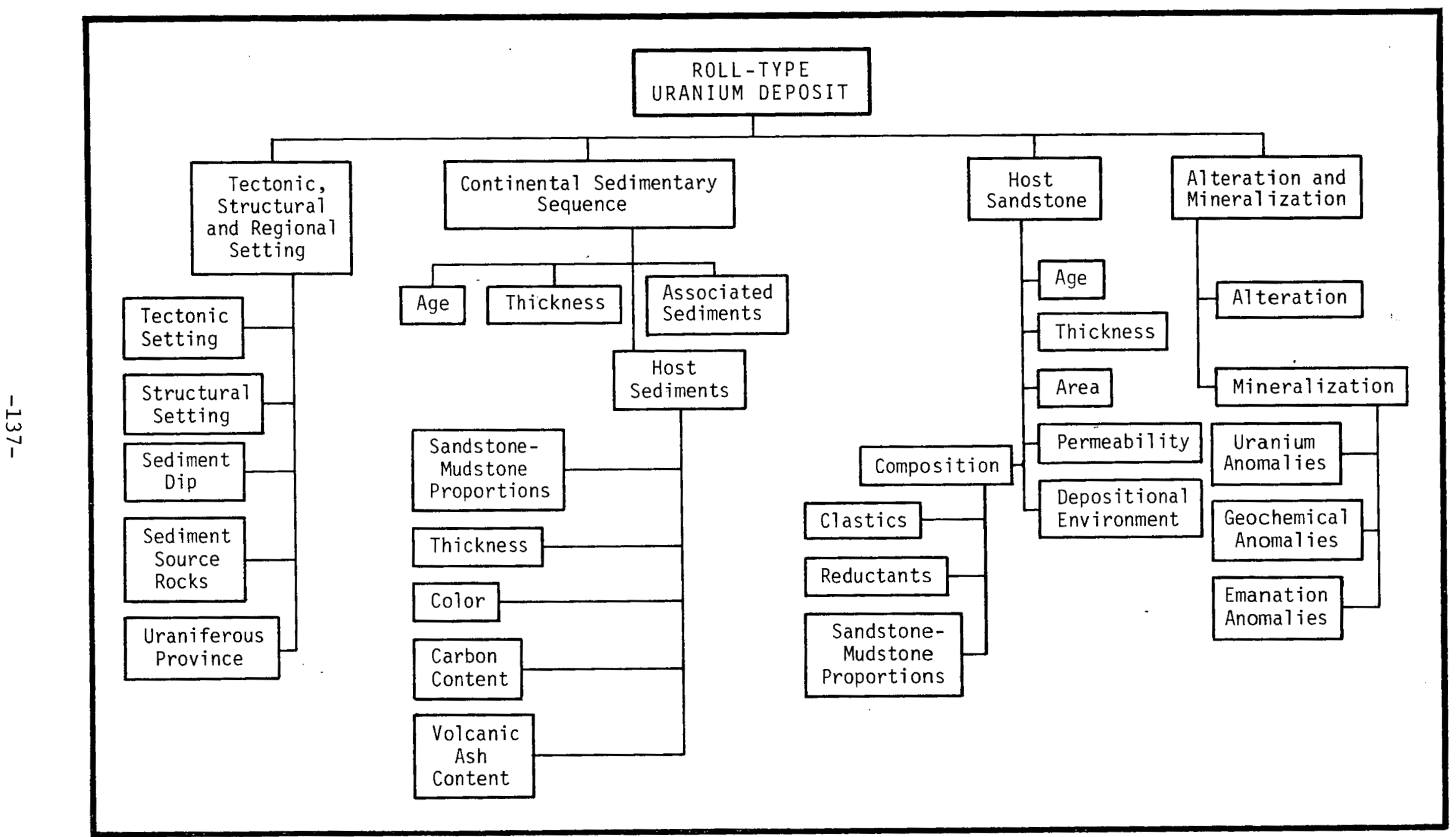

Figure 53. Recognition criteria net for the roll-type uranium deposits in continental sandstones. 
The selection and definition of criteria is subjective, as discussed earlier, but the estimation of the relative importance of criteria is even more so. The justification for assigning importance or weight is that intuitively we feel some criteria are more important than others. As with the criteria themselves, we have assigned the best set of weights we could develop, but they are entirely subjective and the reader may be justified in modifying our estimates to reflect his data. Weights assigned are obviously only approximations to indicate the relatively encouraging or discouraging nature of a particular definition of a criterion. An estimate of +65 , for example, might as well have been +75 or +50 . We are simply attempting to capture the geologist's approximate estimate of the relative importance of geologic observations as an additional aid in the evaluation of unexplored areas. The

system is subjective and imprecise and likely to remain so, but the subjective information is useful if we can learn to collect and use it properly. It is toward that end that the subjective, relative importances are assigned to al1 criteria in the following section and a simple method for accumulating this information is presented in the Appendix.

\section{Evaluation of Recognition Criteria}

The assignment of importance or weight to recognition criteria may be conveniently explained by referring to the five criteria at the left side of Figure 53 which evaluate the Tectonic, Structural, and Regional Geologic Setting

(TSRS). Each of the five criteria embodies, in the geologists mind, numerous considerations which relate to geological observations, the processes they reflect and their importances to the presence or absence of a uranium deposit. With respect to evaluating TSRS, which in turn will be used with three other criteria to evaluate the likelihood of occurrence of a deposit, these are presumably the five most important criteria that could have been selected, and we assume no important criteria have been omitted.

In most cases, any five such criteria will have different importances in establishing the intermediate criterion above them. Therefore, importance or weight is assigned to each recognition criterion with the aid of the relation shown in Figure 54. Weights are assigned to each criterion independent1y of the others based on how sufficient the presence of the criterion by itself is for establishing the presence of favorable TSRS or how sufficient the absence of the criterion is by itself to establish the absence of favorable TSRS. For example, if one knows the tectonic setting in some area under consideration, but knows nothing about the four other criteria, how favorable is TSRS? The types of tectonic settings one might consider include:

intermontane basin continental interior basin coastal plain graben miogeosyncline eugeosyncline

The favorability of TSRS decreases from intermontane basin to eugeosyncline (additional depositional environments might have been chosen but, as with all 
the criteria, no attempt is made to be inclusive, merely to provide enough examples so that the geologist can use his judgement in applying the criteria to other geologic conditions). Therefore, the likelihood of favorable TSRS being present is highest if the tectonic setting is an intermontane basin, and lowest if it is a eugeosynclinal depositional environment.

Suppose the tectonic setting is known to be an intermontane basin. Since this is the type of depositional environment in which many roll-type deposits occur, this is suggestive or "good news" for the presence of the proper TSRS, but how suggestive is it? In Figure 54, modifying expressions have been arranged along arbitrary scales from 0 to +100 and 0 to -100 as an aid to the geologist in estimating the importance or weight for a particular criterion. The positive scale is used when geologic observations confirm the presence of a recognition criterion, i.e. it is encouraging or "good news" for the occurrence of the higher level criteria. The negative scale is used when the criterion is absent, i.e. it is discouraging for the presence of favorable TSRS. Zero is used when the available data neither increases nor diminishes the favorability of TSRS. The scale ranges and modifying expressions might have been chosen quite differently, for example, 0 to 1.0 or 0 to 500 and with different words such as "favorable" and "very favorable" for the positive scale and "unfavorable" and "extremely unfavorable", etc., for the negative scale. The conventions used were arbitrarily chosen but seemed easy to work well as explained below.

To assign weights to a criterion, the geologist asks, "If the criterion is absolutely perfect, i.e., if the area under evaluation is a perfect intermontane basin, how suggestive is it that favorable TSRS is present? In the case of tectonic setting, we feel the presence of an intermontane basin is extremely suggestive that the TSRS is perfect, i.e., the criteria by itself is so important that if present with no information on other criteria it provides 80 percent certainty that the TSRS is perfect.

If on the other hand, the tectonic setting is in a eugeosyncline, it effectively rules out the possibility of a proper TSRS, thus we have designated it almost completely insufficient and assigned it a value of -95 . We might have assigned a value of -100 , but out of respect for the vagaries of the earth, we have left some room. for surprises. Anyway, the result is essentially the same. The presence of a eugeosynclinal environment essentially destroys the potential for not only a favorable TSRS, but for a roll-type deposit. It is up to the geologist using this system to place proper weights on environments not specifically included using his judgement and the examples provided.

The tectonic setting is not the only criterion for evaluating TSRS. Structural trends such as faulted or folded basin margins against basement uplifts and fracture patterns extending out into the basin sediments also have their impact. When considered without any other information, the presence of such favorable structures is, however, only mildly suggestive (+35) for the presence of favorable TSRS. Similarly, if such favorable structures are absent and unfavorable ones are present, they are believed to be moderately discouraging, hence, are assigned a -65 .

Sediment dip, on the other hand, is at best only weakly suggestive if it is perfectly favorable, i.e., less than about 3 degrees, but as the dip increases it begins to have a negative effect on the favorability for TSRS. In fact, in 


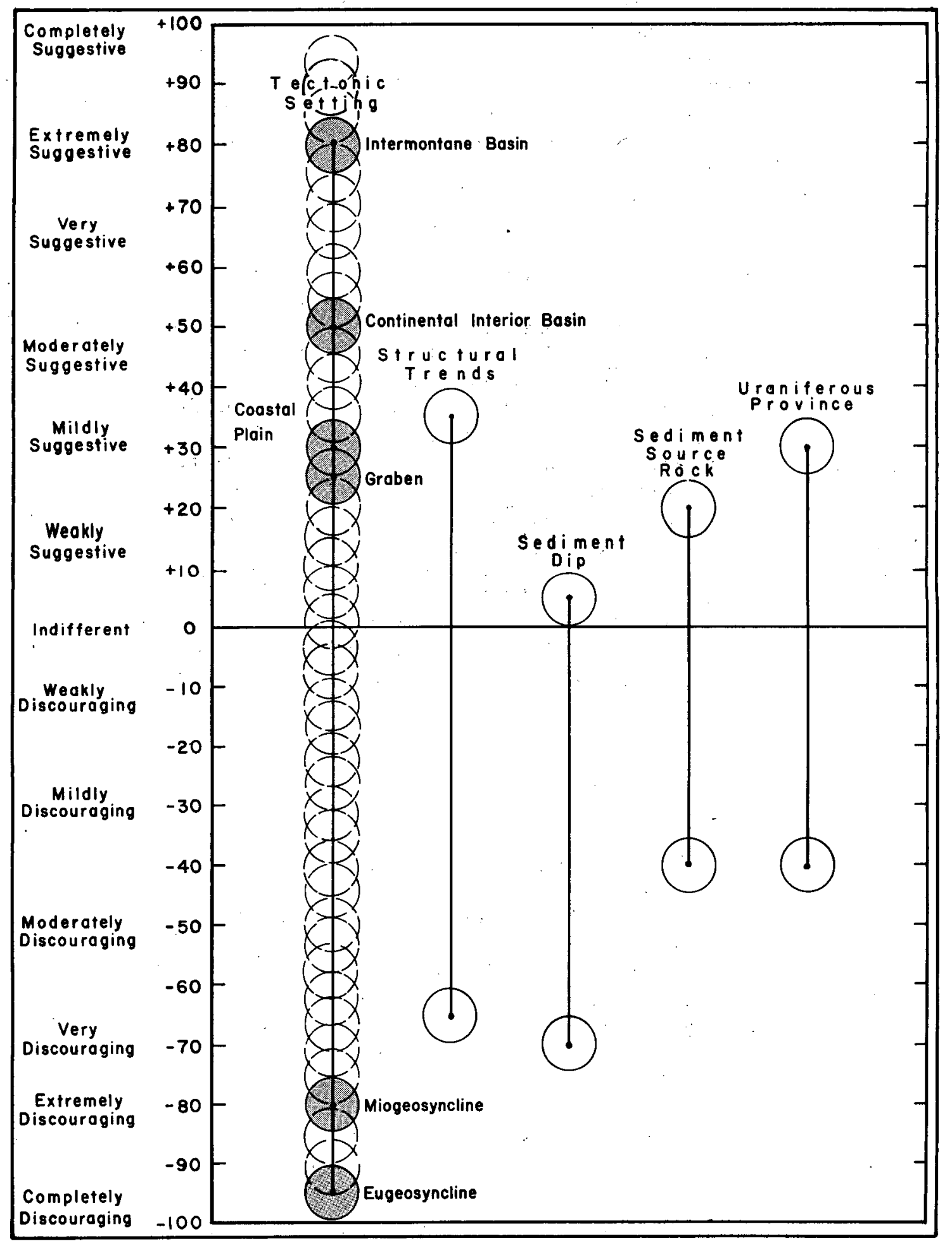

Figure 54. Example of the assignment of weights to recognition criteria using the five criteria that determine Tectonic Structural and Regional Geologic Setting. Tectonic Setting is shown in detail. 
the worst case, where the rocks, are strongly deformed, we consider the situation very discouraging and have assigned a value of -70 . The other two criteria, Sediment Source Rock and Uraniferous Province, have similarly been assigned suggestivity values for when they are present and perfectly favorable, and negative values for when they are absent or completely discouraging for the presence of favorable TSRS. Values have been assigned for all the lowest level criteria and for the intermediate level criteria for evaluating the yet higher level criteria, and are tabulated in Table 4. The "model" is now ready to use in the evaluation of real data.

The reader will have perhaps made two observations from the foregoing discussion. First, it is assumed that each recognition criterion is independent of all others, i.e. each is used separately to evaluate the criterion above it. In fact many criteria are not independently variable, and would affect the likelihood of the higher criterion differently in combination than they do by their simple sum. However, error or bias due to nonindependence of variables is lost in the accumulated uncertainties of the geologic data and the conclusions we make about them. Secondly, there is a continuous range of decreasing favorability for each criterion starting at the maximum weighting and extending down to the most discouraging, "worst case". In applying the method, the geologist should use his judgement in selecting favorability values for his field observations. For example, he may believe his area is a graben but that it is a very large graben system which would increase its favorability up toward Intermontane Basin (Fig. 54). He might, for example, assign a value of +60 in contrast to our value of 25 and be justified in doing so. This method is to be used with geologic judgement and good sense and is not a substitute for them.

\section{Description of Recognition Criteria}

In order to apply the recognition criteria net (Fig. 53) to the evaluation of field areas it now remains to (1) describe the recognition criteria so that they can be evaluated with field geologic observations and (2) assign numerical value to various states of the criteria depending upon how suggestive or discouraging the states are for the intermediate criterion above them. In the following pages, the criteria are organized by the major second level criterion shown in Figure 53. The subjective weights, estimated according to procedures described in the preceding paragraphs, for the various criteria accompany the definitions.

\section{Tectonic Structural and Regional Geologic Setting}

\section{Tectonic Setting}

The tectonic setting strongly affects the type and availability of sediment, the character of the streams that transport the sediment, the rate of sedimentation, the development of hydrologic conditions favorable for mineralization and lastly the preservation of any deposits that may have formed. 
Tab1e 4. Estimates of the values (Scale +100 to -100 ) for recognition criteria for roll-type deposits for establishing the favorability of the criteria above them in the criteria net (see Fig. 53).

Criterion

Roll-type uranium deposit

Tectonic, Structural and Regional Geologic Setting

Continental Sedimentation Sequence Host Sandstone

Alteration and Mineralization
Estimate of Suggestivity When Present or Favorable

\author{
Estimate of \\ Discouragement \\ When Absent or \\ Unfavorable
}

Tectonic, Structural and Regional

Geologic Setting

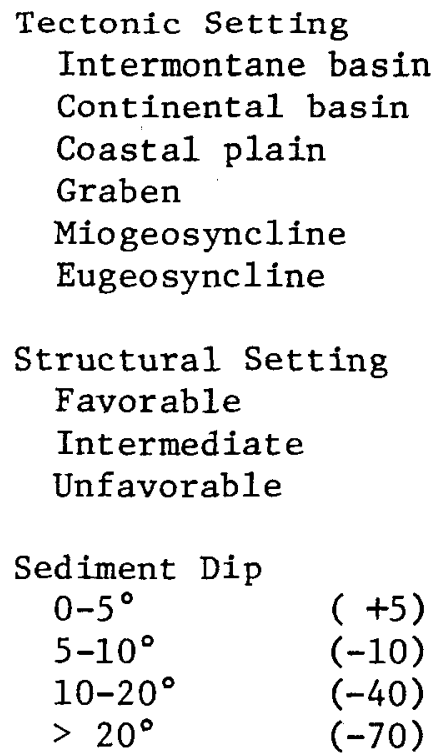

Sediment Source Granitic

Mixed

Non-granitic

$(-40)$

Uraniferous Province

Favorable

Weakly Favorable $(+10)$

Unfavorable 
Table 4. (continued)

\section{$\underline{\text { Criterion }}$}

Continental Sedimentary Sequence

Age

Tertiary

Mesozoic

Devonian-Permian

Pre-Devonian

$(-95)$
Estimate of Estimate of Suggestivity Discouragement When Present When Absent or or Favorable
Associated Sediments

Volcanics and reduced beds $(+20)$

Reduced beds

only reduced beds

$(-50)$

Host Sediments

$+60 *$

$-95 *$

Sandstone-mudstone proportions

Thickness

Color

Carbon content

Volcanic ash content

$+20 \quad-50$

$+110 \quad-320$

Host Sediments

$$
\begin{array}{lc}
\text { Sandstone-mudstone } & \text { proportions } \\
>75 \% \text { sand } & (-40) \\
60-75 \% \text { sand } & (-10) \\
40-60 \% \text { sand } & (+20) \\
<40 \% \text { sand } & (-20)
\end{array}
$$

Thickness

$>500^{\prime}$

$(+20)$

$200^{\prime}-500^{\prime}$

$100^{\prime}-200^{\prime}$

( 0$)$

$(-75)$

$<100^{\prime}$

$(-90)$
Color
$>80 \%$ gray $(+20)$
$25-50 \%$ gray $(0)$
$<20 \%$ gray $(-60)$

$$
+20
$$$$
-40
$$
20
$-40$
$-90$
$-60$

$+20$

$+20$ 
Table 4. (continued)

\section{Criterion}

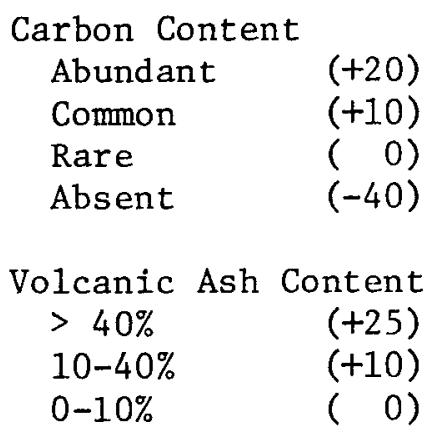

Estimate of Estimate of Suggestivity Discouragement When Present When Absent or or Favorable Unfavorable

$+20$ $-40$
$+25 \quad 0$

$+105$

$-230$

Host Sandstone

Age

Pre-Mesozoic

$(-95)$

Triassic-Jurassic

Cretaceous

$(+15)$

Paleocene-Eocene

$(+25)$

Oligocene

$(+10)$

Miocene-Recent

$(-5)$

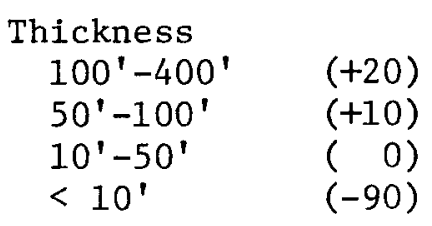

Area

Large $(+25)$

Intermediate $(+15)$

Sma 11

$(-80)$

Permeability

$\mathrm{High}$

Medium

$(+25)$

$(+5)$

$(-25)$

Very low

$(-50)$ \begin{tabular}{l}
$+25-95$ \\
\hline
\end{tabular}

$+20 \quad-90$

$+25-80$

$+25-50$

$+45-60$

Depositional Environment

Proximal fan

$(-50)$

Dista1 fan

Bed load

$(+35)$

$(+45)$

$(-60)$ 
Table 4. (continued)

\section{Criterion}

Composition
Clastics
Reductants
Sandstone-mudstone proportions
Estimate of Estimate of Suggestivity Discouragement When Present When Absent or or Favorable Unfavorable

$$
+40 *
$$$$
-95 *
$$

Composition

$$
\begin{aligned}
& \text { Clastics } \\
& >20 \% \text { feldspar } \\
& 5-10 \% \text { feldspar } \\
& \text { no feldspar }
\end{aligned}
$$$$
+45 \quad-10
$$

Reductants

$\begin{array}{ll}>1 \% & (+60) \\ \text { Trace } & (+20) \\ \text { None } & (-90)\end{array}$

Sandstone-mudstone proportions
$>75 \%$ sand
$60-75 \%$ sand
$(0)$
$40-60 \%$ sand
$(+20)$
$<40 \%$ sand
$(+35)$
$(-30)$

Alteration and Mineralization

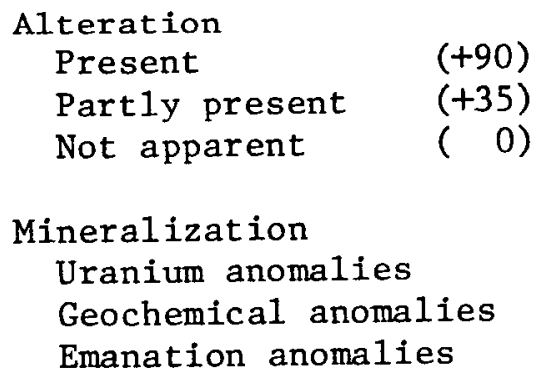

$+90$

0

$$
\begin{array}{ll}
+80 * & -40 * \\
-170 & -40
\end{array}
$$

Mineralization

$\begin{array}{ll}\text { Uranium Anomalies } \\ \text { Several } & (+80) \\ \text { Few } & (+35) \\ \text { None } & (-30)\end{array}$

$$
+80 \quad-30
$$


Table 4. (continued)

\section{Criterion}

Geochemical Anomalies

Strong (+50)

Moderate $\quad(+30)$

None

$(-30)$

Emanation Anomalies

Present

Absent

$(+10)$

$(0)$
Estimate of Estimate of Suggestivity Discouragement When Present When Absent or or Favorable Unfavorable

*Values assigned to intermediate level criterion. 
In order of decreasing favorability, some possible tectonic settings for roll-type uranium deposits are:

(1) Intermontane basin $\quad+80$

(2) Continental Interior Basin $\quad+50$

(3) Coastal Plain 130

(4) Graben (downfaulted blocks) +25

(5) Miogeosyncline $\quad-80$

(6) Eugeosyncline -95

Structural Setting

The Wyoming basins, hosts for the best-known ro11-type uranium deposits, are commonly related to basin margin structural features. Faulting, perhaps reactivations of structures as old as Precambrian, and folding produced the uplifts that bound the basins and the depressions in which the basins are located, features that are absolutely essential for deposition of favorable host rocks and subsequent mineralization. Structures that cut across intermontane basins and affect the host and younger rocks tend to disrupt lithologic continuity, produce steep dips, disrupt hydrologic continuity, hence, are all considered to be adverse factors.

Structural settings, in order of decreasing favorability, are:

(1) Basins that are bounded by faults and/or folds that are parallel to the basin axis and that separate uplifted crystalline basement rocks from the relatively undisturbed basin sediments

(2) Basins that are bounded by faults and/or folds parallel to the basin that separate uplifted crystalline basement rocks from the slightly disturbed basin sediments

(3) Basins not bounded by. structure or which contain basin sediments considerably disturbed by structures cutting across the basin axis or which are metamorphosed

Sediment Dip

Steep dip of host sediments is considered to be an adverse factor. Steep dips in host rocks prior to mineralization adversely affect the processes by which roll-type uranium deposits form; steep dips originating after mineralization affect the preservation of already formed deposits.

\footnotetext{
${ }^{1}$ Not discussed in this report; refer to report by Smith and Adams entitled, "Geology and recognition criteria for sandstone uranium deposits in mixed fluvial-shallow marine sedimentary environments".
} 
Ranges of dips are 1isted below in order of decreasing favorability:
(1) 0-5 Degrees
$+5$
(2) 5-10 Degrees
$-10$
(3) 10-20 Degrees
(4) > 20 Degrees
$-70$

Sediment Source Rocks

Arkoses derived from granitic rocks are generally considered to be the most suitable hosts for roll-type uranium deposits although the Black Hills deposits, for example, are in non-arkosic, quartzose sandstones. Granitic rocks may be a source of some of the uranium in some of the deposits. Therefore, the presence of granitic basement rocks as a source for the accumulating basin sediment affects the favorability of sediments deposited in basins and the likelihood of subsequent mineralization. The favorability of arkoses probably relates more to their. physical properties and their depositional environment than to their mineralogical and/or chemical composition.

(1) The source area for the basin sediments contains abundant granitic rocks that were presumably exposed during basin sedimentation $+20$

(2) The source area for the basin sediments contains sparse granitic rocks that were presumably exposed during basin sedimentation

(3) The source area for basin sediments does not include granitic rocks

\section{Uraniferous Province}

There is some evidence that uranium deposits in sandstone occur most frequently in what have been termed "uranium-rich provinces." These are areas in which the rocks, particularly the Precambrian granitic rocks or the refractory minerals in them such as zircons, acid, volcanics, continental clastic sediments, pegmatites and even metamorphic rocks, contain more than an average amount of uranium or average number of anomalies. Granitic basement rocks are the most useful, if present, even though there is considerable evidence that they lose some of their uranium during weathering and that this loss may be appreciable to depths of several hundred feet below the ground surface. Although undoubtedly somewhat leached, the uranium content of the freshest available samples of granitic rocks in the cores of the ranges is of value in uranium potential assessment. So also is the thorium content of these rocks and the occurrence and abundance of anomalies in other rock types.

(1) The granitic rocks of the province contain more than $10 \mathrm{ppm} U$ and/or uranium anomalies in other rock types are significantly more abundant than normal. 
(2) The granitic rocks of the province contain 5-10 ppm uranium and/or the uranium anomalies in other rock types are slightly more abundant than normal.

(3) The granitic rocks of the province contain less than $4 \mathrm{ppm} U$ and less than $20 \mathrm{ppm}$ Thorium and/or uranium anomalies in other rock are less than normal. -40

\section{Continental Sedimentary Sequence}

Continental sedimentary sequences, most commonly of Tertiary age, are the preferred habitat for roll-type uranium deposits. The sequences contain predominantly fine-grained sediments but also contain important intervals of sandstone and siltstone several hundred feet thick that serve as hosts for the deposits. Parts of the sequence may be reduced, other parts oxidized (i.e., red beds), but reduced rocks are an important component of the sequence. Volcanic ash is an important component of portions of all productive sequences. Carbonaceous material is abundant in some sediments within the sequence, sparse in other parts. Angular unconformities, some very slight, are present throughout the sedimentary pile which generally is many thousands of feet thick in the center of the basin, thinning toward the edge.

Favorable sedimentary sequences also include settings where rocks of the type described in the foregoing paragraph are (a) interbedded with marginal marine sediments, as in the Texas Coastal Plain, and (b) overlie with angular unconformity rocks which contain reduced aquifers as is the case with the TertiaryCretaceous boundary in the Black Hills and Weld County areas.

Age

Age has a bearing on the probability that a continental sedimentary sequence contains roll-type uranium deposits. The principal deposits in the Wyoming basins are found in a sequence of continental sediments spanning the time interval Paleocene to Recent. Ro11-type deposits of lesser importance are found on the flanks of some basins in rocks of Late Cretaceous age that generally are or were overlain by rocks of Tertiary age. Deposits of modest size are found on the west and northwest flank of the Black Hills in continental coastal plain rocks of Early Cretaceous age. The age of the mineral deposits, particularly those in Cretaceous rocks, is probably considerably younger than the age of the host rocks and related to the Tertiary volcanic-rich sediments.

Age favorability decreases in the sequence:
(1) Tertiary
(2) Mesozoic $+15$
(3) Devonian-Permian
(4) Pre-Devonian 


\section{Thickness}

The thickness of the sedimentary sequence is of some importance to the favorability of the sediments, particularly if it happens to be thin.

Continental sedimentary sequence is:

(1) more than 2,000 feet thick

$+10$

(2) 1,000-2,000 feet thick

$+5$

(3) 500-1,000 feet thick

$-20$

(4) less than 500 feet thick

\section{Associated Sediments}

The 1ithology of the sediments which occur within the Continental Sedimentary Sequence with the Host Sediments is a guide to the favorability for uranium considering the following factors:

(1) The associated sediments contain volcaniclastics and may contain carbonaceous material and subordinate amounts of oxidized arkosic sands and shales $+20$

(2) The associated sediments contain carbonaceous reduced sediments but lack abundant volcaniclastic sediments

(3) The associated sediments are dominantly red-bed sequences with negligible volcaniclastic or carbonaceous, reduced sediments

\section{Host Sediments}

\footnotetext{
"Host Sediments" refer to a particular part of the Continental Sedimentary Sequence composed of sediments that were deposited in related depositional environments and may include one or more sedimentary members, formations or even groups. Host Sediments is a more broad and general criterion than, for example, Host Sandstone which may or may not be known to occur within the Host Sediments. Data on Host Sediments is useful, therefore, in initial regional reconnaissance whereas data on Host Sandstone will be required in more detailed target evaluations. The "host sediments" will generally be part of a Continental Sedimentary Sequence which either contains uranium deposits or anomalies, or is being evaluated for its uranium potential (i.e., the Wind River Formation). As used herein the Host Sediments relate principally to the braided (and to a much lesser extent the meander channel-fill) sand bodies and the related shales, lignite, and smaller channel sands. In some settings, the requisite sedimentary components, including volcaniclastics and reduced mudstones, may occur in an angular unconfornity relation with the host sand underlying the probable source rock as in the case in the Black Hills and Weld County, Colorado.
} 
The character of the Host Sediments is of critical importance in judging the favorability of an area for roll-type uranium deposits. It governs the permeability, distribution of reductants within the unit, the position and shape of any mineralized bodies, and their size and grade. The characteristics of both the sandstones and siltstones and their interbedding relations affect the favorability of the Host Sediments and ultimately a Host Sandstone. The abundance, thickness, and character of the mudstones in the Host Sediments furnish clues to their likely hydrologic and chemical contributions to the formation of uranium deposits within the associated and interbedded sands.

\section{Sandstone-Mudstone Proportions}

The proportions of sand and shale in the total thickness of the Host Sediments is a guide to the hydrologic favorability of the sediment pile. Too high a proportion of sands yields high transmissivity which tends to destroy deposits, whereas too little sand suggests lacustrine or meander belt depositional environments and low overall permeability, both of which are of distinctly lower favorability than the mid-fan region of a braided fluvial system. A sequence of repeating thick sands and shales increases the favorability as it signals changing depositional environments, a sign of tectonic instability which is compatible with tectonism and vulcanism. The favorability of different ranges in sandstone percent of the Host Sediments may be approximately assigned as follows, where the sandstone percentage is:

greater than $75 \%$

$$
60-75 \%
$$$$
40-60 \%
$$

less than $40 \%$
$+20$

\section{Thickness}

Thick, interbedded sequences of Host Sediments are more likely to produce large roll-type deposits main1y because of the size of the system, i.e. a potentlally larger uranium source, a greater area of groundwater sweep and greater groundwater flow across a given aquifer cross-section all favor larger, higher-grade deposits. Approximate total thickness ranges for the Host Sediments and their favorability are:

more than 500 feet

$200-500$ feet

$100-200$ feet

less than 100 feet

Color

Color reflects the state of oxidation of a sediment. Red mudstone may be present in minor amounts without adversely affecting favorability but predominantly red mudstones suggest an oxidizing environment of deposition unfavorable for subsequent uranium deposition. 
The percentage of gray or greenish-gray color (or shades of buff or tan if weathered) in contrast to shades of red in unweathered (i.e., unaffected by surface oxidation) is:

$\begin{array}{lrr}\text { more than } \quad 80 \% & +20 \\ \text { between } 25 \text { and } 50 \% & 0 \\ \text { less than } \quad 20 \% & -60\end{array}$

\section{Carbon Content}

Carbon content (either vegetal or humic) of mudstone and the sandstone enhances the deposition of uranium by maintaining the reducing potential of the sedimentary environment through which the oxidizing uranium-bearing ground water flows. Carbonaceous sediments suggest abundant vegetation, humid tropical or semitropical climates and rapid burial at the time of sedimentation, al1 factors that favor subsequent deposition of uranium.

Mudstones and sandstone in the Host Sediments containing considerable $(1 \% \pm$ or more) carbonaceous material are:

$\begin{array}{llr}\text { abundant } & \text { (more than } 25 \% \text { of sediments) } & +20 \\ \text { common } & \left(\begin{array}{l}5 \text { to } 25 \% \text { of sediments) } \\ \text { rare }\end{array} \text { (1ess than } 5 \% \text { of sediments) }\right. & +10 \\ \text { absent } & ( & 0 \% \text { of sediments) }\end{array}$

Volcanic Ash Content

Volcanic ash, or bentonitic clay derived from the alteration of volcanic ash, is considered to be the most likely source of uranium and other elements for most roll-type deposits. Its presence in the mudstones of the Host Sediments, particularly those in juxtaposition to potential host sandstones, satisfies the need for a source rock in or near an area under investigation.

The percentage of tuffaceous mudstone and/or sandstone (of the total mudstone and/or sandstone) is:

$$
\begin{array}{rr}
\text { greater than } 40 \% & +25 \\
10-40 \% & +10 \\
0-10 \% & 0
\end{array}
$$

Host Sandstone

The host sandstone is a specific, potentially favorable sandstone unit within the host sedimentary sequence. It has several important and readily identifiable characteristics that are closely related to the source of the sediment 
and the fluvial system responsible for its transportation and deposition.

Favorable host sandstones may be found only in a relatively small segment of a depositional system, and then only locally within a generally favorable area. Host sandstone may be present at several stratigraphic intervals or in several lateral, somewhat parallel belts. If the belts or stratigraphic intervals are sufficiently interconnected hydrologically by permeable sand-filled channels, they need be considered as a single host sandstone; if not interconnected, they need be considered as separate host sandstones.

The favorability of Host Sandstones is based on the following characteristics.

$\underline{\text { Age }}$

Rol1-type uranium deposits are found in host sandstones ranging in age from Jurassic to Eocene. Sandstones of Paleocene and Early Eocene age are the favored hosts for large and/or high-grade deposits. Of the many factors that may relate to age, we feel that climatic changes may be most important.

Possible host sandstone ages are ranked as follows:

(1) Pre-Mesozoic

(2) Triassic-Jurassic

(3) Cretaceous

(4) Paleocene-Eocene

(5) Oligocene

(6) Miocene-Recent

$$
\begin{aligned}
& -95 \\
& -50 \\
& +15 \\
& +25 \\
& +10 \\
& -5
\end{aligned}
$$

\section{Thickness}

Host Sandstone thickness, which customarily has associated width and length ranges, affects transmissivity and the size of orebodies one can reasonably expect. Thin sandstones not only restrict the maximum potential size of orebodies, but they also limit the gross flow of solutions through the host, due to tortuosity and restricted flow paths, thus inhibiting the formation of high-grade, thick deposits.

An "order of magnitude" estimate of the relations between Host Sandstone thickness and favorability is:

(1) The Host Sandstone is 100-400 feet thick. +20

(2) The Host Sandstone is 50-100 feet thick. +10

(3) The Host Sandstone is 10-50 feet thick. 0

(4) The Host Sandstone is less than 10 feet thick. -90 


\section{Area}

Areal distribution affects favorability in a similar way as does thickness. Narrow Host Sand or those deposited over short distances have poor hydrologic characteristics.

The effect of areal distribution on Host Sand favorability may be estimated as follows:

(1) Host Sandstone has width measured in miles and length measured in tens of miles.

(2) Host Sandstone has width measured in thousands of feet and length measured in miles.

(3) Host Sandstone has width measured in hundreds of feet and length measured in thousands of feet.

\section{Permeability}

Permeability, essential for the formation of roll-type uranium deposits, is governed by grain size, grain size distribution, and cementation at the time of mineralization. Most large and/or high-grade deposits are found in mediumto coarse-grained, moderately well-sorted sandstones. Although there are some exceptions, well sorted coarse conglomerate and boulder beds are not generally favorable hosts because of their high permeability. In order of decreasing favorability, sandstones may be classified as follows:

(1) The potential host is a medium- to coarse-grained moderate- to well-sorted permeable sandstone.

(2) The potential host is a medium- to fine-grained moderate- to wel1-sorted somewhat permeable sand stone.

(3) The potential host is a we11-sorted coarse conglomerate of very. high permeability.

(4) The potential host is dominantly a poorly-sorted fine-grained sandstone of low permeability.

\section{Composition}

Three compositiunal considerations significantly affect the favorability of the Host Sandstone:

Clastics are most commonly dominated by mixtures of quartz and feldspars. Arkosic sandstones are considered to be the best hosts for large and/or high grade roll-type uranium deposits. This is probably related more to permeability of the host than to its chemical composition. Arkoses also indicate proximity to granitic rocks that may have served'as a source of the elements in the deposits.

Favorability decreases as follows: 
(1) The Host Sandstone is an arkose containing $20 \%$ or more feldspar.

$+45$

$+30$

feldspar.

(3) The Host Sandstone is composed predominantly of quartz and other non-feldspar clasts.

Reductants significantly affect the favorability of the unweathered and una1tered Host Sandstone, in particular the presence or absence of pyritemarcasite and/or carbonaceous material, generally in the form of plant fragments. Sandstone containing carbonaceous material or diagenetic pyritemarcasite, derived either through bacterial sulfate reduction in the presence of carbonaceous material or some unrelated mechanism, seem equally capable of forming suitable host rocks.

The favorability decreases as follows:

(1) The unaltered Host Sandstone contains an average concentration of pyrite-marcasite and/or carbonaceous plant material in the range of 1 percent. $+60$

(2) The unaltered Host Sandstone contains traces of pyrite-marcasite and/or carbonaceous material.

(3) The unaltered Host Sandstone contains no carbonaceous material or pyrite-marcasite.

Sandstone-mudstone Proportions, as reflected in the presence of some shale and siltstone interbeds within the Host Sandstone, are considered favorable as they retard transmissivity and inhibit the flushing of a deposit. Excessive shales, however, may restrict groundwater flow, hence, the formation of a deposit. The percentage of sand is related to favorability as follows:

more than $75 \%$

$60-75 \%$

$+20$

$40-60 \%$

$+35$

less than $40 \%$

Depositiona1 Environment

We recognize that other recognition criteria used to evaluate the favorability of a Host Sandstone, in particular permeability, organic content and sandstonemudstone proportions, are strongly related to the depositional environment. However, the advantage and importance of recognizing the depositional environment warrants, we feel, whatever duplication may result from including Depositional Environment as a recognition criteria in its own right.

The depositional environment determines the character of the sediment deposited from a fluvial system. The very favorable medium- to coarse-grained 
rocks, containing carbonaceous debris, deposited rapidly, and to some extent interbedded with mudstones, are deposited in the moderately high energy parts of a fluvial system. The highest energy part of such a system, the proximal alluvial fan is generally unfavorable because it is excessively permeable, contain little carbonaceous material, and may have become oxidized soon after deposition. The most favorable part of the fluvial depositional system extends from the medial or mid-fan position, through the distal fan and bedload stream, to approximately the zone of mixed-load stream transport and deposition. The lower reaches of the fluvial system (suspended load) is low energy, contains little sand, and is generally unfavorable for significant deposits.

Favorability factors follow:

(1) The sandstone is in a proximal fan (exclusively very coarse-grained and contains mostly boulders and gravel)

(2) The host sandstone is in a medial or distal fan (grave1 and cross-bedded, coarse-grained sand).

(3) The host sandstone is in: a bed-1oad or mixed-load sediment (coarse- to medium-grained, cross-bedded channel sandstone interbedded with mudstone)

(4) The host sandstone is in a suspended-load sediment (medium- to fine-grained, occurs in small bodies and in predominantly very fine-grained sediments)

\section{Alteration and Mineralization}

Rock alteration and uranium mineralization may not be directly observable during the early stage of evaluation and exploration of new areas and the uranium potential must be evaluated with recognition criteria discussed in previous pages. For example, the types of alteration present in the Shirley Basin cannot be observed in weathered surface outcrops but other favorable factors far outweigh this one negative one. However, as exploration proceeds and more detailed information becomes available, including geochemical and geophysical data and subsurface rock samples, observations regarding alteration and mineralization will become possible.

\section{Alteration}

The pyrite and marcasite, and/or carbonaceous material, always present in unaltered, favorable Host Sandstones, are destroyed both by subsurface alteration and by surface weathering. Weathering of pyritic sandstones generally produces shades of tan, brown, or yellow in the weathered material, while alteration associated with uranium deposition may produce pink or red shades in the altered material. The pink or red colors persist even though the material is subsequently weathered at the surface. The pink and red coloration of altered sandstone is distinct and is restricted to portions of the sandstones, both features.that serve to distinguish it from the widespread red coloration of many red-bed sediments. In some areas the alteration associated with mineralization may be shades of yellow or greenish-yellow, as in 
the Shirley Basin, or may be described as "bleached" as in the Gas Hills. Recognition of such alterations in weathered outcrop may be difficult.

(1) Some surface outcrops of the Host Sandstone

display shades of yellow, brown or tan, whereas others display red or pink alteration colors or greenish-yellow or yellow or bleached shades over broad areas. Subsurface samples display any of the same alteration colors or iron sulfide or carbonaceous material-bearing gray sands (i.e., both altered and unaltered sand has been seen)

(2) Surface outcrops of the Host Sandstone display red or pink or other "alteration" colors, but no yellow-brown or tan colors (i.e., the altered sand is visible but no unaltered sand has been seen)

(3) Surface samples display only tan, brown, or yellow colors (i.e., there is no altered sand)

Mineralization

Uranium Anomalies. The presence of chemical or radiometric uranium anomalies in the host sandstone, reflecting uranium or its daughters, is favorable for the presence of roll-type uranium deposits. On outcrop, anomalies may be associated with small lenses of organic material, fossil bones, clay galls or the boundary between sands and shales. Outcrops of altered sandstone, even updip from large uranium deposits, may show very little radioactivity because uranium is readily leached from roll-type deposits by the very solutions that form the deposits. In the subsurface uranium anomalies associated with sandshale boundaries or high background concentrates in sands or shales, as indicated by gamma logs or core assays, are encouraging.

It should be noted that arkosic sediments may produce gross gamma radiuactivity anomalies due to concentrations of thorium (i.e., monazite) and/or potassium (i.e., potash feldspar). These anomalies must not be confused with those due to uranium daughters.

(1) Outcrop and/or limited subsurface logs and samples of the Host Sandstone contain several anomalies of several times background.

(2) Outcrop and/or limited subsurface logs and samples of the Host Sandstone have few radiometric anomalies that are several times background.

(3) Outcrops and/or limited subsurface logs and samples of the Host Sandstone have no radiometric anomalies. 
Geochemical Anomalies. Geochemical anomalies, if used with caution, may be useful in assessing the uranium potential of an area. Numerous factors affect the uranium concentration of waters, so that, for example, high uranium concentrations (40-50 ppb) occur in water within some rocks containing little. uranium (5 ppm) while very modest anomalies (10-15 ppb) occur in waters issuing from rocks containing orebodies. However; as a general rule, ground water containing more than 5 to $10 \mathrm{ppb}$ uranium flowing in host rocks not undergoing strong oxidation suggest that significant mineralization may be present in the area.

(1) Ground water issuing from springs or from wells in the host formation, not under going rapid oxidation, contains more than $15 \mathrm{ppb}$ uranium.

(2) Ground water issuing from springs or from wells in the host formation, not undergoing rapid oxidation, contains between 5 and $15 \mathrm{ppb}$ uranium, and/or soil and/or stream sediment samples show anomalous radioactivity due td uranium concentrations

(3) Ground water issuing from springs or from wells in the host formation, not undergoing rapid oxidation, contains less than $5 \mathrm{ppb}$ uranium and/or soil and stream sediment samples contain no uranium anomalies

Emanation Anomalies. Radon and helium anomalies (daughter products of uranium disintegration) can be, but are not necessarily, related to roll-type uranium deposits. Some investigators report successful use of radon and helium surveys in determining the presence of uranium in buried host rocks; others report failure. At best, such surveys should be used to strengthen conclusions based on other recognition criteria.

(1) Radon and/or helium anomalies are present in the area.

(2) Radon and/or helium anomalies are not present in the area.

There is much lacking in the foregoing compilation of recognition criteria. Some important criteria have probably been omitted while some of those included are ambiguous and difficult to evaluate. Some definitions are perhaps too abbreviated to provide proper guidance for the selection of criteria weights. Undoubtedly the weights assigned to the various favorable and unfavorable states of some of the criteria are not what the reader would have chosen. We have attempted to address all these problems, but we recognize the criteria will benefit enormously through refinements by experienced geologists. In spite of these shortcomings, we feel the recognition criteria considerably improve the usefulness of the geologic data, that was compiled and interpreted in earlier sections of the report, for resource studies and exploration. 
REFLECTIONS AND CONTINUING STUDIES

The application of geologic information to resource studies and exploration for roll-type uranium deposits continues to evolve. Resource studies are only now being developed, both in theory and in practice, and much room exists for improvement. By contrast, considerable exploration experience has been accumulated, and some discoveries will continue to result from pushing the "stateof-the-art" to deeper targets, geological analogous provinces, and lower grade ores. We expect, however, that critical review of "explored" productive and neighboring areas, and geologic environments with slightly but significantly different geologic characteristics, will also yield exploration rewards. It is toward both of these possibilities that we have attempted to identify geologic guides to aid in selecting targets and choosing priorities.

In spite of the abundance of data for roll-type uranium deposits, there are numerous inadequacies and ambiguities in the data, and therefore, in the conclusions one might draw from them. In this report, we have attempted to document the data for roll-type deposits, so that the uncertainties in the interpretations we have drawn are readily obvious. Some of the more serious inadequacies in the data base for these deposits are tabulated below, as a guide for future studies.

(1) Too few roll-type deposits have been thoroughly and systematically studied. In our opinion, this should once again become a high priority of the U. S. Geological Survey. Studies should not be limited to the deposits, or to their environments of formation, but should document and integrate the two. "Environment of formation" is used in the broadest sense to incorporate regional structural settings, uranium source rocks, and all other factors responsible for important aspects of ore formation.

(2) The economic characteristics of roll-type deposits, such as ore grade distribution, size and shape of ore pods, and frequence and distribution along roll fronts, are geologically controlled. Geologic criteria should be develcped to better anticipate these characteristics, for use in resource studies, exploration, and mining. For example, the character of alteration zones in the Great Divide Basin seems to relate to the grade and width of the ore, which probably reflects the geology and hydrology of the system. In the Powder River Basin, wider ore tends to be lower in grade, but there is no indication that this is related to the character of the alteration zone. The documentation of such relations would undoubtedly improve all aspects of resource exploration and mining activities.

(3) Alteration associated with roll fronts is now recognized to take such a variety of forms that the model for ore formation is oversimplified. A geologist must be familiar with the range of examples, some of which are difficult to recognize, without much guide as to where the various types are likely to occur. The habits and geologic controls of various alteration assemblages should be documented as an aid to anticipating ore occurrences in different geologic environments. Why, for example, were iron-rich clays produced in greenish-yellow to yellow alteration assemblages in the Shirley Basin, whereas, reddish, hematitic alteration resulted in presumably roll front process in the Powder River Basin? 
(4) The abundance of certain elements associated with roll-type deposits varies between districts, particularly vanadium (higher in the Black Hills District and the Kaycee Area) and molybdenum (higher in the Gas Hills District and the Crooks Gap Area). Study of such variations will provide information on the source of elements and mechanisms of roll front formation.

(5) Perhaps the most important single control on the habit and character of rol1-type deposits is the abundance and distribution of reductant within the host sandstone. The distribution of pyrite and organic material should be studied in the unaltered sandstones of all major districts, so as to ascertain what observations will help anticipate the size, shape, and grade characteristics of deposits in new areas or in new host rocks.

(6) The investigation of fluvial depositional environments, and its application to uranium deposits, has expanded significantly in recent years, much to the credit of those who have popularized this work. It is now generally accepted as a tool in exploration. More emphasis and training are required, however, to transfer the theory of depositional environments to the interpretation of sedimentary systems in practical field problems. 


\section{POTENTIAL FOR ROLL-TYPE DEPOSITS IN CONTINENTAL SEDTMENTS IN THE UNITED STATES}

Roll-type uranium deposits in Cretaceous and Tertiary continental sediments contain a significant part of the U. S. uranium reserves. Such deposits occur in Russia, Australia, Argentina, Brazil, and probably in other areas throughout the world. In the last twenty years, considerable effort has been expended in the search for roll-type uranium deposits in the Wyoming basins and elsewhere in areas of similar geologic environments. The uranium reserves and resources of known uraniferous districts have been augmented greatly by this activity, but there has been little success in finding new uraniferous districts.

It is beyond the scope of this report to review specific areas for their potential for this type of deposit. However, it is suggested that the recognition criteria presented in this report be applied to previously explored and/or part1y explored areas in an attempt to make certain that the most favorable parts of generally favorable areas have been explored adequately. As an example, a restudy of the Tertiary rocks lying north of the Wind River, Sweetwater, and north Laramie Mountains might locate inadequately explored areas where large northward-flowing streams deposited sediments favorable for subsequent uranium deposition. Similar studies of the flanks of the Powder River, Bighorn, Green River, Washakie, and Red Desert Basins, as well as the belt of Tertiary and Cretaceous rocks off the east flank of the Laramie Mountains and Front Range of Colorado, might show favorable areas that are inadequately explored. Special situations that influence the character of fluvial deposition, such as the ridge of Frontier sandstone in the Shirley Basin and the northwesterly-trending ridges of Mesozoic and older rocks in the Gas Hills, are important considerations in any regional favorability study. Some drilling may be required to determine the presence or absence of such special situations. We are optimistic that significant new discoveries of roll-type deposits will be forthcoming. 


\title{
APPENDIX
}

\author{
ESTIMATION OF GEOLOGIC FAVORABILITY FOR THE \\ OCCURRENCE OF ROLL-TYPE DEPOSITS
}

\author{
Introduction
}

Numerous methods have been used for estimating the geologic favorability or expected resource endowment of an area for various types of ore deposits (Cargi11 and Clark, 1978; Singer and Overshine, 1979; Voelker et a1, 1979; Harris and Carrigan, 1980). In this section we present a simplified method for estimating the favorability of an area for the occurrence of rol1-type deposits using the recognition criteria net (Fig. 53) and the weights assigned to the recognition criteria (Table 4). It must be emphasized that the favorability estimate reflects only the general geologic similarities between known deposits, as defined by the recognition criteria, and the geologic characteristics of an area in which similar deposits might occur. A higher degree of geologic similarity yields a higher favorability estimate, suggesting a greater likelihood that the type of deposit for which the recognition criteria were developed is present in the untested area. No attempt is made to estimate the number of deposits or their geologic size, grade, and continuity. These characteristics require information about the known deposits which, in many cases, is not yet available.

The use of this method presumes that sufficient geologic information is available for the area of study so that weights can be confidently assigned to the recognition criteria. In most cases, geologic data are incomplete and values cannot be assigned to all criteria. Using the method described below the absence of a value for a criterion is analogous to assigning it a value of zero. This could introduce a significant error in the interpretation of the favorability estimate if the geologist fails to note where data were lacking. If the true favorability of the criterion is significantly higher than zero, the absent data leads to a fallaceously low estimate of the area's favorability. This is a common situation, particularly in resource evaluation of Federa1 lands where adequate geologic information is customarily unavailable for the systematic evaluation for all types of deposits. Geologic favorability simply cannot be estimated until an adequate data base is available. Where data are lacking, the large negative and positive weights indicate those recognition criteria for which data must be acquired. The assignment of a weight of zero may also significantly overestimate favorability if that criterion is in fact very discouraging. There is no substitute for a sufficient data base.

\section{Calculation of Estimated Favorability}

The procedure for calculating an estimated favorability may be conveniently explained by returning to the discussion of Tectonic, Structural and Regional Geologic Setting (TSRS), considered under Evaluation of Recognition Criteria. 
Weights were assigned to various favorable and unfavorable states of the five criteria that determine the favorability of TSRS. To evaluate the favorability of TSRS for field areas, favorability values, based on field observations, are assigned to the five criteria. Table 5 presents hypothetical results for four imaginary field areas. In accumulating the values of the recognition criteria, negative and positive values are accumulated separately, but in like fashion.

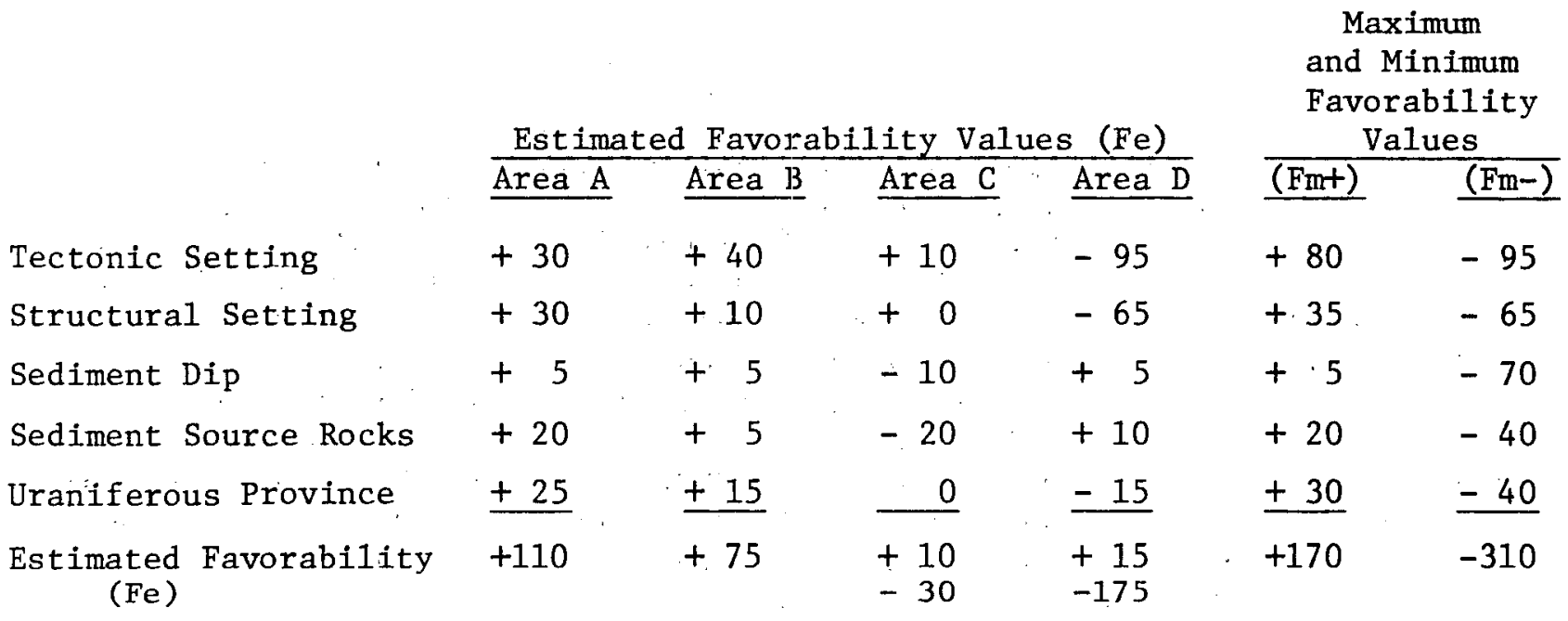

Table 5. Hypothetical recognition criteria values, from four imaginary field areas, for the five criteria that determine Tectonic, Structural and Regional Geologic Setting.

In Test Area A, for example, the tectonic setting has been assigned a value of +30. Structural setting provides an additional 30, and so forth for the other three criteria, yielding an estimated favorability (Fe) for TSRS of +110 . However, if all the criteria had been perfect, and the maximum favorability values had been used, the sum of the five criteria would have been +170 (Table 5). It is necessary, therefore to normalize the estimated favorability by dividing it by the maximm favorability (Fm) value to yield a normalized (Fn) value:

$$
\frac{\mathrm{Fe}}{\mathrm{Fm}}=\mathrm{Fn} \quad \text { or }, \quad \frac{110}{170}=.65
$$

The favorability of TSRS for Area $A$ is 65 , i.e. very suggestive.

For Area $D$ the negative and positive criteria are combined in like manner but separately, then normalized and summed:

Negative values--

Tectonic

Structural

Uranium

Setting

Setting

Province

$-95+$

$(-65)$

$+\quad(-15)$

$=-175$ 


$$
\frac{\mathrm{Fe}}{\mathrm{Fm}-}=\mathrm{Fn} \quad \text { or, } \quad \frac{175}{310}=-.56
$$

Positive values--

$$
\begin{array}{ll}
\begin{array}{c}
\text { Sediment } \\
\text { Dip }
\end{array} & \begin{array}{c}
\text { Sediment } \\
\text { Source Rocks }
\end{array} \\
\frac{\mathrm{Fe}}{\mathrm{Fm} t}=\mathrm{Fn} & \text { or } \quad \frac{15}{170}=.09
\end{array}
$$

Combining the normalized positive and negative values $(-56+9=-47)$ one determines that Area $D$ has a relatively large negative number, hence, a discouraging Tectonic, Structural and Regional Geological Setting. This is not a very favorable area in which to prospect for a roll-type deposit. In fact, the large negative values for tectonic setting and structural setting would be sufficient in most geologists' minds to kill the potential of this area. The explorationist should thus not waste further time in collecting other detailed geological information from this area. This example shows that the geologist making the evaluation must always inspect individual negative numbers, which, if sufficiently discouraging, can destroy the entire potential, for the area, even though the accumulation of numerous positive observations may yield a net positive answer.

It can be seen in Figure 53 and Table 4 that Tectonic, Structural and Regional Geologic Setting is merely one of four criterion that define the favorability for a roll-type deposit. From Table 4 it will be seen that TSRS can contribute a maximum of 50 points, hence, in our example for Area A, TSRS becomes:

$$
0.65 \times 50=32=\text { Applied Normalized Favorability (Fna) }
$$

This value can now be used with similar values for the three other intermediate criteria in calculating the value of the higher-order criterion, namely, the favorability for a roll-type deposit. In a similar manner, all other terminal criteria are combined to evaluate intermediate criteria until the favorability for a roll-type deposit has been evaluated. This favorability is not necessarily equivalent to the probability of a deposit being present as is discussed in a later paragraph.

\section{Completeness and Confidence of Geologic Data}

If the field geologist has complete geologic data and is equally and completely confident about all his field observations, he may evaluate the favorability according to the preceding paragraphs. In most cases, however, he will lack data and probably have various levels of confidence regarding the data that does exist. His confidence for different observations may range from completely certain that, for example, a uranium source rock is present, to no confidence (i.e., he does not know) that the age of the prospective basin sediments is Eocene. In such circumstances methods can be devised to modify the favorability estimates, but no calculations can overcome the lack of data or confident observation. Such shortcomings must be carefully documented and the resulting favorability estimate interpreted accordingly. 


\section{Interpretation of Results}

Favorability estimates prepared by the methods described in the preceding paragraphs should be accepted and used only after review of four important parameters:

(1) The final favorability estimate itself;

(2) Favorability estimates for intermediate level criteria;

(3) Favorability values for individual criteria, particularly large negative values;

(4) Completeness of data and certainty of observations.

Each of these is briefly discussed with reference to favorability estimates made for three areas in the United States and presented in the next section.

The final favorability estimate reflects the net geologic favorability of an area when compared with type areas (i.e., the Powder River Basin, Gas Hills, Shirley Basin, etc.) for which the recognition criteria net and maximum and minimum favorability values were selected. A score of 100 indicates a perfect geologic fit, i.e. virtual assurance that at least one deposit is present. A final score of zero indicates a very low level of favorability, provided the geologic data was complete, and the prospects of finding a deposit would be comparable to hitting a deposit with a dart thrown at a map of North America. A favorability of +50 , therefore, is only half as favorable as one of +100 . If the score is based on high confidence in the observations and complete data (i.e., no zeros assigned to criteria) the area may be said to possess only half the favorable attributes necessary for a deposit. This does not mean the area has a fifty percent chance of a deposit being present. In our judgement the likelihood is less, but how much less is difficult to estimate. At a favorability estimate of zero the chances of a deposit being present are vanishingly sma11, and at negative favorabilities the chances are even worse. Figure 55 is our subjective attempt to relate estimated favorability of an area to the chances of a deposit being present within that area. The relationship suggests that the chances of a deposit being present decrease more rapidly than the estimated favorability. At 75 percent favorability, for example, we feel there is about a 50 percent chance that a deposit is present.

The estimated favorability values for the second level criteria of the recognition criteria net (Fig. 53) for the three areas considered in the next section are also useful for interpreting the favorability estimates. Inspection of these values, which are tabulated below, permits one to determine the contribution of each intermediate level criterion to the final estimated favorability. 


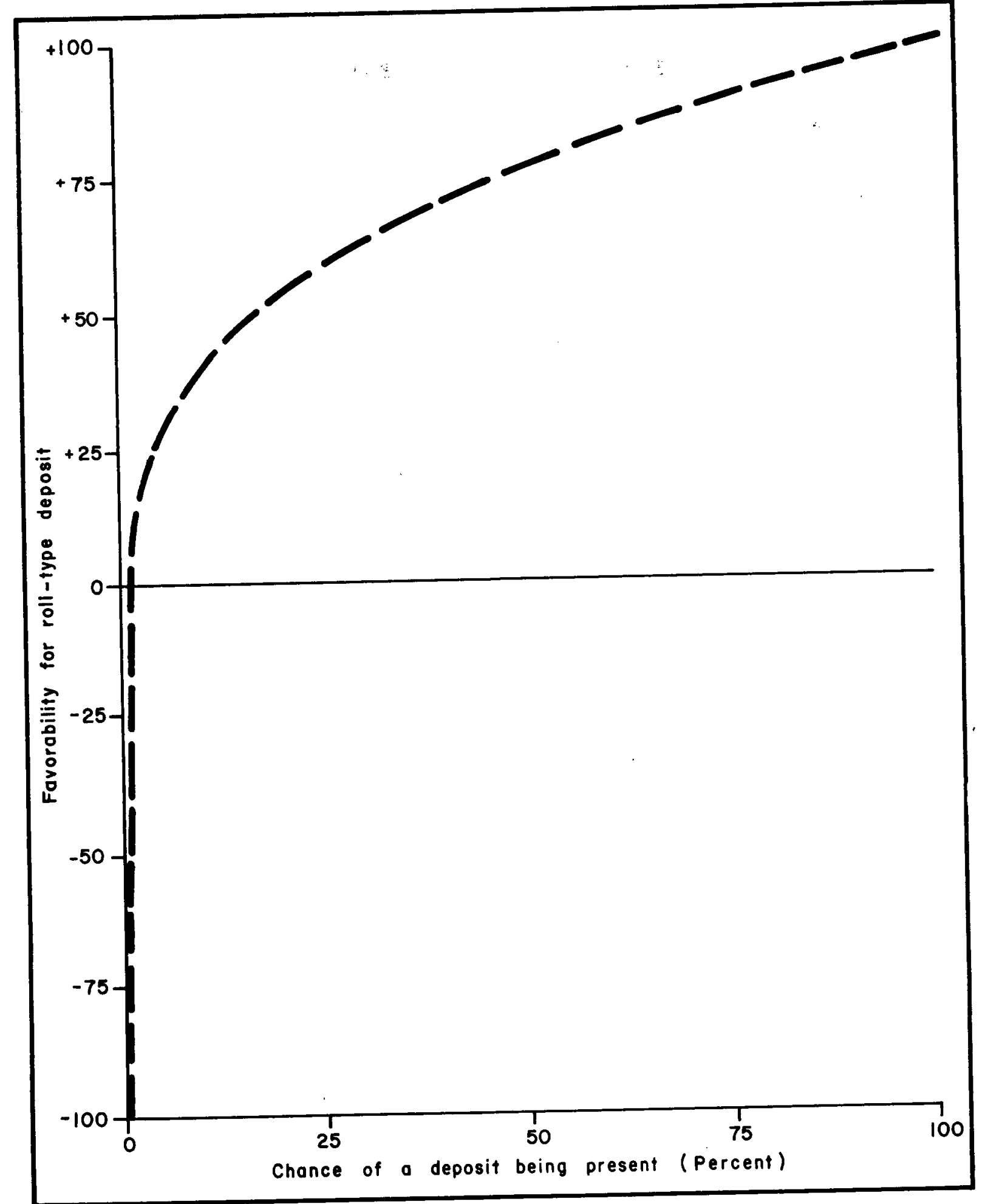

Figure 55. Schematic relation between calculated favorability for roll-type deposits and the chances of a deposit being present within the area evaluated. 
Second Leve1 Criterion

Tectonic, Structural and Regional Geologic Setting

Continental Sedimentary Sequence

Host Sandstone

Alteration and Mineralization

\begin{tabular}{ccc}
\multicolumn{3}{c}{ Applied Normalized } \\
\multicolumn{2}{c}{ Favorability Values } \\
\hline Gas & Shirley & Weld \\
Hills & Basin & County
\end{tabular}

50

60

38

63
50

57

40

55
Maximum

Applied Normalized. Values $\left(\mathrm{Fm}^{+}\right)$

50

65

40

70

The favorability of the Shirley Basin is decreased relevant to the Gas Hills by values for "Alteration and Mineralization" which reflects the difficulty of identifying surface alteration and radioactivity in the Shirley Basin. The favorability of Weld County is low for all criteria when compared to the Wyoming Basins, but is particularly low for Alteration and Mineralization. By similar comparisons one can pursue favorability values down through lower levels of the criteria net and ascertain exactly where favorable and unfavorable observations are originating.

Strongly negative values for individual criteria are, in some cases, sufficient to essentially kill the potential of an area. In the final favorability estimate a single large negative value may become lost in generally positive criteria values, hence, the geologist must inspect the values of individual criteria.

Finally, the completeness of the data, hence the number of zero values, may produce erroneous estimated favorability values. In exploration, low favorability values due to incomplete and uncertain data are not as unfavorable as low favorability values resulting from negative or low positive criteria values. In resource studies, however, the absence of data could yield an apparent favorability much lower (or higher) than the area warrants. Careful inspection must be made of incomplete and uncertain data and the resulting favorability estimate interpreted accordingly. Where new data or more certain observations are needed, the criteria weights will indicate which observations are most important to obtain.

\section{Examples of Favorability Estimates for Three Areas}

In the following pages, recognition criteria are used to estimate the geologic favorability for roll-type deposits in one continental interior basin in Colorado and two intermontane basins in Wyoming. These examples are chosen to illustrate one simple method for developing favorability estimates. In each case the favorability of the area was obviously known as roll-type deposits had already been discovered. In order to keep the exercise as realistic as possible, however, we have used only geologic data available before extensive exploration and mining in the three areas. 
The following abbreviations are used throughout:

$$
\begin{aligned}
& \text { GHD }=\text { Gas Hills district, Wyoming } \\
& \mathrm{SBD}=\text { Shirley Basin district, Wyoming } \\
& \mathrm{WCD}=\text { Weld County district, Colorado } \\
& \mathrm{Fe}=\text { Estimated favorability value } \\
& \mathrm{Fm}=\text { Maximum favorability value } \\
& \mathrm{Fn}=\text { Normalized Favorability value } \\
& \text { Fna }=\text { Normalized applied favorability value }
\end{aligned}
$$

Estimated Favorability ( $F e$ ) is simply the sum of the favorability values assigned to each of a group of criteria that determines the favorability of a higher intermediate level criterion, based upon field data.

Maximum Favorability (Fm) is the sum of the maximum values that could be assigned to those criterion.

Normalized Favorability $(\mathrm{Fn})$ is equal to the estimated favorability divided by the maximum favorability. It may be interpreted, therefore, as a percentage of the total possible favorability of the criteria.

Normalized Applied Favorability (Fna) is the normalized favorability of a group of criteria which is then multiplied by the weight assigned to the criterion above; the product is the weight for that higher level criterion that is then used with other criteria to calculate the favorability of the next higher level criteria. For example (Fig. 53), three criteria determine the favorability of composition. The normalized favorability obtained from these three criteria are not used directly in combination with the five other criteria that establish the favorability of Host Sandstone, but is multiplied by the positive or negative value $(+40,-95)$ assigned to Composition (see Table 4). It is necessary to calculate Fna only where higher level criteria have been assigned separate weight values, generally toward the top of the criteria net and all are indicated by asterisks in Table 4.

I. Tectonic Structural and Regional Geologic Setting (TSRS)

The favorability of TSRS is determined by the geology of five criteria:

(a) Tectonic Setting

GHD +80 (an intermontane basin)

SBD +80 (as above)

WCD +50 (continental interior basin)

(b) Structural Setting

GHD +35 (relatively undisturbed basin sediments)

SBD +35 (undisturbed basin sediments)

WCD +0 (slightly disturbed sediments) 
(c) Sediment Dip

$$
\begin{array}{ll}
\text { GHD }+5 & \left(\operatorname{dip} 2^{\circ} \pm\right) \\
\text { SBD }+5 & \left(\operatorname{dip} 2^{\circ} \pm\right) \\
\text { WCD }+5 & \left(\text { dips as much as } 5^{\circ} \pm\right)
\end{array}
$$

(d) Sediment Source Rocks

GHD +20 (granitic source rocks)

$\mathrm{SBD}+20$ (as above)

WCD +10 (granitic and metamorphic source rocks)

(e) Uraniferous Province

GHD +30 (above normal uranium)

SBD +30 (as above)

WCD +10 (normal uranium)

(f) TSRS Score

The favorability estimate (Fe) for TSRS is the sum of the individual favorability numbers derived from field data:

$$
\begin{aligned}
& \text { Fe GHD }=80+35+5+20+30=\underline{170} \\
& \text { Fe SBD }=80+35+5+20+30=\underline{170} \\
& \text { Fe WCD }=50+0+5+10+10=\underline{75}
\end{aligned}
$$

Reference to Table 4 shows that the maximum favorability for TSRS that could be derived from the sum of these criteria is

$$
\mathrm{Fm}=80+35+5+20+30=170
$$

We now want to know the extent to which the estimated favorabilities achieved the maximum potential favorability, hence we divide the estimate ( $\mathrm{Fe}$ ) by the maximum (Fm). One also notes (Table 5) that the maximum values of TSRS for evaluating the favorability for a roll-type deposit are +50 and -95 . We can therefore, combine two steps and calculate directly the normalized applied favorability which is the contribution to the favorability for roll-type deposit:

$$
\text { Fna }=\frac{F e}{F m} \times 50,
$$

thus,

$$
\begin{aligned}
& \text { Fna GHD }=\frac{170}{170} \times 50=\underline{50} \text { (a perfect score) } \\
& \text { Fna SBD }=\frac{170}{170} \times 50=\underline{50} \text { (as above) } \\
& \text { Fna WCD }=\frac{75}{170} \times 50=\underline{22} \text { (out of a possib1e 50) }
\end{aligned}
$$


II. Continental Sedimentary Sequence

(a) Age

$$
\begin{array}{ll}
\mathrm{GHD}=+20 & \text { (Tertiary) } \\
\mathrm{SBD}=+20 & \text { (as above) } \\
\mathrm{WCD}=+15 & \text { (Tertiary and Cretaceous) }
\end{array}
$$

(b) Thickness

$$
\begin{array}{ll}
\text { GHD }=+10 & \text { (slightly over } 2000 \text { feet }) \\
\text { SBD }=+5 & \text { (slightly under } 2000 \text { feet }) \\
W C D=+5 & \text { (slightly under } 2000 \text { feet) }
\end{array}
$$

(c) Associated Sediments

$$
\begin{array}{ll}
\mathrm{GHD}=+20 & \text { (not much carbon) } \\
\mathrm{SBD}=+20 & \text { (as above) } \\
\mathrm{WCD}=+20 & \text { (as above) }
\end{array}
$$

(d) Host Sediments

(1) Sandstone-mudstone proportions

$$
\begin{array}{ll}
\mathrm{GHD}=+20 & \text { (good sandstone/mudstone ratio) } \\
\mathrm{SBD}=+20 & \text { (as above) } \\
\mathrm{WCD}=-10 & \text { (sandstone/mudstone ratios fair) }
\end{array}
$$

(2) Thickness

$$
\begin{array}{ll}
\text { GHD }=+20 & \text { (thicknesses exceed } 500 \text { feet) } \\
\text { SBD }=+20 & \text { (as above) } \\
\text { WCD }=+20 & \text { (as above) }
\end{array}
$$

(3) Color

$$
\begin{array}{ll}
\text { GHD }=+20 & \text { (only small percentage oxidized) } \\
\mathrm{SBD}=+20 & \text { (as above) } \\
\mathrm{WCD}=+20 & \text { (as above) }
\end{array}
$$

(4) Carbon content

$$
\begin{array}{ll}
\mathrm{GHD}=+20 & \text { (considerable carbon) } \\
\mathrm{SBD}=+20 & \text { (as above) } \\
\mathrm{WCD}=+10 & \text { (considerable carbon in Laramie Formation) }
\end{array}
$$


(5) Volcanic ash content

$$
\begin{array}{ll}
\mathrm{GHD}=+10 & \text { (ash is in overlying formation) } \\
\mathrm{SBD}=+10 & \text { (as above) } \\
\mathrm{WCD}=+10 & \text { (as above) }
\end{array}
$$

(6) Host sediment score

$$
\begin{aligned}
\text { Fe GHD }= & 20+20+20+20+10=+90 \\
\text { Fe SBD }= & 20+20+20+20+10=+90 \\
\text { Fe WCD }= & \text { Pos. } 20+20+10+10=+60 \\
& \text { Neg. }-10
\end{aligned}
$$

Fm pos. $=+20+20+20+20+25=+105$

Fm neg. $=-40-90-60-40-0=-230$

The assigned weight for Host Sediment is +60 (Table 4), hence:

$$
\begin{aligned}
& \text { Fna GHD }=\frac{90}{105} \times 60=\underline{+51} \text { (out of possible 60) } \\
& \text { Fna SBD }=\frac{90}{105} \times 60=\underline{+51} \text { (out of possible 60) } \\
& \text { Fna WCD Pos }=\frac{60}{105}=+.57 \\
& \text { Fna WCD Neg }=\frac{-10}{-230}=+.04 \\
& \text { Fna WCD Net }=.57 .04=+.53 \\
& \text { Fna WCD }=+.53 \times 60=\underline{32} \text { (out of possible 60) }
\end{aligned}
$$

(e) Continental Sedimentary Sequence Score

$$
\begin{aligned}
& \text { Fe GHD }=20+10+20+51=101 \\
& \text { Fe SBD }=20+5+20+51=96 \\
& \text { Fe WCD }=15+5+20+32=72 \\
& \text { Fm }=20+10+20+60=110 \\
& \text { Fna GHD }=\frac{101}{110} \times 65=\underline{60} \text { (out of a possible 65) } \\
& \text { Fna SBD }=\frac{96}{110} \times 65=\underline{57} \text { (out of a possible 65) } \\
& \text { Fna WCD }=\frac{72}{110} \times 65=\underline{43} \text { (out of a possible 65) }
\end{aligned}
$$


III. Host Sandstone

(a) Age

$$
\begin{array}{lll}
\text { GHD } & +25 & \text { (early Tertiary) } \\
\text { SBD }+25 & \text { (as above) } \\
\text { WCD }+15 & \text { (Cretaceous) }
\end{array}
$$

(b) Thickness

$$
\begin{array}{lll}
\text { GHD }+20 & \text { (up to } 300 \text { feet thick) } \\
\text { SBD }+20 & \text { (over } 100 \text { feet thick) } \\
\text { WCD }+10 \text { (general1y less than } 100 \text { feet thick) }
\end{array}
$$

(c) Area

$$
\begin{array}{lll}
\text { GHD }+25 & \text { (very wide unit) } \\
\text { SBD }+25 & \text { (1ength exceeds width) } \\
\text { WCD +25 } & \text { (extensive unit) }
\end{array}
$$

(d) Permeability

$$
\begin{array}{lll}
\text { GHD }+25 & \text { (very permeable) } \\
\text { SBD }+25 & \text { (as above) } \\
\text { WCD }+5 & \text { (fairly permeable) }
\end{array}
$$

(e) Depositional Environment

GHD +35 (medial-distal fan)

SBD +45 (bed-load fluvial)

WCD +20 (fluvial and marginal marine)

(f) Composition

(I) Clastics

$$
\begin{array}{lll}
\mathrm{GHD} & +45 & \text { (arkose) } \\
\mathrm{SBD} & +45 & \text { (arkose) } \\
\mathrm{WCD}+30 & \text { (subarkose) }
\end{array}
$$

(2) Reductants

$$
\begin{array}{lll}
\text { GHD } & +60 & \text { (pyrite and carbon) } \\
\mathrm{SBD}+60 & \text { (as above) } \\
\mathrm{WCD}+60 & \text { (as above) }
\end{array}
$$

(3) Sandstone-mudstone proportions

$$
\begin{array}{lll}
\text { GHD }+35 & \text { (the most favorable proportions) } \\
\mathrm{SBD}+35 & \text { (as above) } \\
\mathrm{WCD}+20 & \text { (excessive sandstone) }
\end{array}
$$




\section{(4) Composition score}

$$
\begin{aligned}
& \text { Fe GHD }=45+60+35=140 \\
& \text { Fe SBD }=45+60+35=140 \\
& \text { Fe WCD }=30+60+20=110 \\
& \text { Fm }=45+60+35=140 \\
& \text { Fna GHD }=\frac{140}{140} \times 40=\underline{40} \text { (a perfect score) } \\
& \text { Fna SBD }=\frac{140}{140} \times 40=\underline{40} \text { (a perfect score) } \\
& \text { Fna WCD }=\frac{110}{140} \times 40=\underline{1} \text { (out of a possible 40) }
\end{aligned}
$$

(h) Host Sandstone Score

$$
\begin{aligned}
& \text { Fe GHD }=25+20+25+25+35+40=170 \\
& \text { Fe SBD }=25+20+25+25+45+40=180 \\
& \text { Fe WCD }=15+10+25+5+20+31=106 \\
& F m=25+20+25+25+40+45=180 \\
& \text { Fna GHD }=\frac{170}{180} \times 40=\underline{38} \text { (out of a possible 40) } \\
& \text { Fna SBD }=\frac{180}{180} \times 40=\underline{40} \text { (a perfect score) } \\
& \text { Fna WCD }=\frac{106}{180} \times 40=\underline{24} \text { (out of a possible 40) }
\end{aligned}
$$

IV. Alteration and Mineralization
(a) Alteration
GHD +80 (alteration in early drill cuttings)
$\mathrm{SBD}+80$ (as above)
WCD +30 (recognized after considerable drilling)

(b) Mineralization

(1) Uranium anomalies

$$
\begin{array}{lll}
\text { GHD } & +80 & \text { (anomalous outcrops) } \\
\mathrm{SBD}+35 & \text { (sparse anomalies) } \\
\mathrm{WCD}+35 & \text { (sparse anomalies) }
\end{array}
$$

(2) Geochemical anomalies

$$
\begin{array}{lrl}
\text { GHD } & +50 & \text { (uranium in ground water) } \\
\mathrm{SBD}+50 & \text { (as above) } \\
\mathrm{WCD} & 0 & \text { (no data) }
\end{array}
$$


(3) Emanation anomalies

$\begin{array}{lrl}\text { GHD } & 0 & \text { (no data) } \\ \text { SBD } & 10 & \text { (radon in well water) } \\ \text { WCD } & 0 & \text { (no data) }\end{array}$

(4) Mineralization score

$$
\begin{aligned}
& \text { Fe GHD }=80+50+0=130 \\
& \text { Fe SBD }=35+50+10=95 \\
& \text { Fe WCD }=35+0+0=35 \\
& \text { Fm }=80+50+10=140 \\
& \text { Fna GHD }=\frac{130}{140} \times 80=\underline{74} \text { (out of a possib1e 80) } \\
& \text { Fna SBD }=\frac{95}{140} \times 80=\underline{54} \text { (out of a possib1e 80) } \\
& \text { Fna WCD }=\frac{35}{140} \times 80=\underline{20} \text { (out of a possib1e 80) }
\end{aligned}
$$

\begin{tabular}{|c|c|c|c|c|}
\hline \multirow[b]{2}{*}{ Second Level Criterion } & \multicolumn{3}{|c|}{$\begin{array}{r}\text { Applied Normalized } \\
\text { Favorability Values }\end{array}$} & \multirow{2}{*}{$\begin{array}{c}\text { Maximum } \\
\text { Applied } \\
\text { Normalized } \\
\text { Values } \\
\end{array}$} \\
\hline & $\begin{array}{l}\text { Gas } \\
\text { Hills } \\
\end{array}$ & $\begin{array}{c}\text { Shirley } \\
\text { Basin }\end{array}$ & $\begin{array}{c}\text { We1d } \\
\text { County } \\
\end{array}$ & \\
\hline $\begin{array}{l}\text { Tectonic, Structural and } \\
\text { Regional Geologic Setting }\end{array}$ & +50 & +50 & +22 & +50 \\
\hline Continental Sedimentary Sequence & +60 & +57 & +43 & +65 \\
\hline Host Sandstone & +38 & +40 & +24 & +40 \\
\hline Alteration and Mineralization & +63 & +55 & +21 & +70 \\
\hline
\end{tabular}

(c) Alteration and Mineralization Score

$$
\begin{aligned}
& \text { Fe GHD }=80+74=154 \\
& \text { Fe SBD }=80+54=134 \\
& \text { Fe WCD }=30+20=50 \\
& \text { Fm }=90+80=170 \\
& \text { Fna GHD }=\frac{154}{170} \times 70=\underline{63} \text { (out of a possible 70) } \\
& \text { Fna SBD }=\frac{134}{170} \times 70=\underline{55} \text { (out of a possible 70) } \\
& \text { Fna WCD }=\frac{50}{170} \times 70=\underline{21} \text { (out of a possible 70) }
\end{aligned}
$$

The second level favorability estimate calculated in the preceding pages can now be tabulated in preparation for calculating the favorability estimates for roll-type deposits in these three areas: 
The favorability for roll-type deposits in these three areas is calculated using the data above and the same procedures used in the preceding calculations.

$$
\begin{aligned}
& \text { Fe GHD }=50+60+38+63=211 \\
& \text { Fe SBD }=50+57+40+55=202 \\
& \text { Fe WCD }=22+43+24+21=110 \\
& \text { Fm }=50+65+40+70=225 \\
& \text { Fn GHD }=\frac{211}{225} \times 100=94 \% \\
& \text { Fn SBD }=\frac{202}{225} \times 100=90 \% \\
& \text { Fn WCD }=\frac{110}{225} \times 100=49 \%
\end{aligned}
$$

These results suggest both the Gas Hills and the Shirley Basin areas are extremely favorable for roll-type uranium deposits, and the Weld county area is moderately favorable. These results are as one would expect and reflect the demonstrated uranium resources of the districts. The percent favorability, as discussed in the text, is probably equivalent to a somewhat lower probability of occurrence for a deposit in any area studied. 


\section{SELECTED REFERENCES}

Adler, H. H., 1974, Concepts of uranium-ore formation in reducing envixonments in sandstones and other sediments, in Formation of uranium ore deposits: Athens, International Atomic Energy Agency, p. 141-168.

Adler, H. H., and Sharp, B. J., 1967, Uranium ore rolls--occurrence, genesis, and physical and chemical characteristics: Utah Geological Society, Guidebook No. 21 (1967), p. 53-77.

Anderson, D. C., 1969, Uranium deposits of the Gas Hills: Wyoming University Contributions to Geology, v. 8, p. 93-103.

Armstrong, F. C., 1970, Geologic factors controlling uranium resources in the Gas Hills district, Wyoming: Wyoming Geological Association, 22nd Field Conference Guidebook, p. 31-44.

Austin, S. R., 1970, Some patterns of sulfur isotope distribution in uranium deposits: Wyoming Geological Association, Earth Science Bulletin, v. 3, no. 2 , p. 5-22.

Bailey, R. V., 1965, Applied geology in the Shirley Basin uranium district, Wyoming: Wyoming University Contributions to Geology, v. 4, p. 27-35.

Bailey, R. V., 1969, Uranium deposits in the Great Divide Basin-Crooks Gap area, Fremont and Sweetwater Counties, Wyoming: Wyoming University Contributions to Geology, v. 8, p. 105-120.

Bailey, R. V., 1980, Comments on Shirley Basin uranium deposits and on the ages of all Wyoming uranium deposits in Eocene host rocks, in Third annual uranium seminar: New York, American Institute of Mining, Metallurgy, and Petroleum Engineers, p. 41-59.

Brobst, D. A., 1961, Geology of the Dewey quadrangle, Wyoming-South Dakota: U. S. Geological Survey Bulletin 1036-B, p. 13-60.

Brunt, D. A., 1978, Uranium in Tertiary stream channels, Lake Frome area, South Australia: Proceedings, Australian Institute of Mining and Metallurgy, No. 266, June 1978, p. 79-90.

Callen, R. A., 1975, Lake Frome Area--regional geology, Tertiary stratigraphy and uranium localization, in Knight, C. L., ed., Economic Geology of Australia and Papua New Guinea, 1. Metals: Australian Institute of Mining and Metallurgy, Monograph No. 5, Victoria, Australia, p. 803-808.

Cargi11, S. M., and Clark, A., eds., 1978, Standards for computer applications in resource studies--a conference held as part of the International Geological Correlations Program, Project 98, Taita Hills, Kenya, November $8-15,1979$, published as Journal of the International Association for Mathematical Geology, v. 10, no. 5, p. 405-642. 
Cheney, E. S., and Jensen, M. L., 1966, Stable isotopic geology of the Gas Hills, Wyoming, uranium district: Economic Geology, v. 61, p. 44-71.

Childers, M. 0., 1970, Uranium geology of the Kaycee area, Johnson County, Wyoming: Wyoming Geological Association, 22nd Field Conference Guidebook, p. $13-20$.

Childers, M. 0., 1974, Uranium occurrences in Upper Cretaceous and Tertiary strata of Wyoming and northern Colorado: Mountain Geologist, v. 11, no. 4, p. 131-147.

Cuppels, N. P., 1963, Geology of the Clifton quadrangle, Wyoming and South Dakota: U. S. Geological Survey Bulletin 1063-H, p. 271-321.

Curry, D. L., 1976, Evaluation of uranium resources in the Powder River Basin, Wyoming: Wyoming Geological Association, 28 th Field Conference Guidebook, p. 235-242.

Dahl, A. R., and Hagmaier, J. L., 1976, Genesis and characteristics of the southern Powder River Basin uranium deposits, Wyoming: Wyoming Geological Association, 28 th Field Conference Guidebook, p. 243-252.

Davis, J. F., 1969, Uranium deposits in the Powder River Basin: Wyoming University Contributions to Geology, v. 8, p. 131-147.

Denson, N. M., Bachman, G. O., Zeller, H. D., 1959, U'ranium-bearing lignite in northwestern South Dakota and adjacent states: U. S. Geological Survey Bulletin 1055B, p. 11-57.

Denson, N. M., and Chisholm, W. A., 1971, Summary of mineralogic and lithologic characteristics of Tertiary sedimentary rocks in the middle Rocky Mountains and the northern Great Plains: U. S. Geological Survey Professiona1 Paper 750-C, p. C117-C126.

Denson, N. M., and Horn, G. H., 1975, Geologic and structure map of the southern part of the Powder River Basin, Converse, Niobrara, and Natrona Counties, Wyoming: U. S. Geological Survey Map I-877.

Department of Energy, 1979, Statistical data of the uranium industry: U. S. Department of Energy GJo-100(79), Grand Junction, Colorado.

Dooley, J. R., Jr., Harshman, E. N., Rosholt, J. N., 1974, Uranium-lead ages of the uranium deposits of the Gas Hills and Shirley Basin, Wyoming: Economic Geology, v. 69, p. 527-53ג.

Files, F. G., 1970, Geology and alteration associated with Wyoming uranium deposits: University of California, Berkeley, Ph.D. dissertation, $113 \mathrm{p}$.

Fischer, R. P., 1970, Similarities, differences, and some genetic problems of the Wyoming and Colorado Plateau types of uranium deposits in sandstone: Economic Geology, v. 65, p. 778-784. 
Gabelman, J. W., 1970, Metallotectonic control of uranium distribution, in Uranium exploration geology: Vienna, International Atomic Energy Agency, p. 187-204.

Gabelman, J. W., and Krusiewski, S. V., 1964, Zonal distribution of uranium deposits in Wyoming, U.S.A.: New Delhi, India, 22nd International Geology Congress, pt. 5, p. 661-672.

Galloway, W. E., 1979, Early Tertiary--Wyoming intermontane basins, in Depositional and ground-water flow systems in the exploration for uranium: Austin, Texas, University of Texas, Bureau of Economic Geology, p. 197-213.

Galloway, W. E., 1979, Fluvial depositional systems, in Depositional and ground-water flow systems in the exploration for uranium: Austin, Texas, University of Texas, Bureau of Economic Geology, p. 13-42.

Garrels, R. M., 1960, Mineral equilibria, New York, Harper and Brothers, 254 p.

Garrels, R. M., and Christ, C. L., 1965, Solutions, minerals, and equilibria: New York, Harper and Row, 450 p.

Gaschnig, J., 1980, Development of uranium exploration models for the Prospector consultant system: SRI International, Project 7856, Menlo Park, California, 603 p.

Gilluly, J., 1973, Steady plate motion and episodic orogeny and magmatism: Geological Society of America Bulletin, v. 84, no. 2, p. 499-514.

Goldhaber, M. B., and Reynolds, R. L., 1979, Origin of marcasite and its implications regarding the genesis of roll-front uranium deposits: U. S. Geological Survey Open-File Report 79-1696, 38 p.

Gott, G. B., and Schnabel, R. W., 1963, Geology of the Edgemont NE quadrangle, Fall River and Custer Counties, South Dakota: U. S. Geological Survey Bulletin 1063-E, p. 127-190.

Gott, G. B., Wolcott, D. W., and Bowles, C. G., 1974, Stratigraphy of the Inyan Kara group and localization of uranium deposits, southern Black Hills, South Dakota and Wyoming: U. S. Geological Survey Professional Paper $763,57 \mathrm{p}$.

Granger, H. C., and Warren, C. G., 1969, Unstable sulfur compounds and the origin of roll-type uranium deposits: Economic Geology, v. 64, p. 160-171.

Granger, H. C., and Warren, C. G., 1978, Some speculations on the genetic geochemistry and hydrology of roll-type uranium deposits: Wyoming Geological Association, 30th Field Conference Guidebook, p. 349-361.

Granger, H. C., and Warren, C. G., 1979, The importance of dissolved oxygen during the formation of sandstone-type uranium deposits: U. S. Geological Survey Open-File Report 79-1603, 21 p. 
Gruner, J. W., 1956, Concentration of uranium in sediments by multiple migration-accretion: Economic Geology, v. 51, p. 495-520.

Grutt, E.W., Jr., 1957, Environment of some Wyoming uranium deposits, in Advances in nuclear engineering: Nuclear Engineering and Scientific Congress, 2d, Philadelphia, Proceedings 2d Conference, v. 2, p. 313-323.

Grutt, E. W., Jr., 1972, Prospecting criteria for sandstone-type uranium deposits, in Bowie, S. H. U., Davis, M., and Ostle, D., eds., Uranium prospecting handbook: London, Institution of Mining and Metallurgy, 346 p.

Hansuld, J. A., 1966, Behavior of molybdenum in secondary dispersion media: Mining Engineering, v. 18, no. 12, p. 75.

Harris, D. P., and Carrigan, F. J., 1980, A probabilistic endowment appraisal system based upon the formalization of geologic decisions, a general description: Grand Junction, Colorado, U. S. Department of Energy, 114 p.

Harshman, E. N., 1962, Alteration as a guide to uranium ore, Shirley Basin, Wyoming: U. S. Geological Survey Professional Paper 450-D, P. D8-D10.

Harshman, E. N., 1966, Genetic implications of some elements associated with uranium deposits, Shirley Basin, Wyoming: U. S. Geological Survey Professional Paper 550-C, p. C167-C173.

Harshman, E. N., 1968, Uranium deposits of Wyoming and South Dakota, in Ridge, J. D., ed., Ore deposits of the United States, 1933-1967 (GratonSales volume): New York, American Institute of Mining, Metallurgy, and Petroleum Engineers, v. 1, p. 815-831.

Harshman, E. N., 1970, Uranium ore rolls in the United States, in Uranium exploration geology: Vienna, International Atomic Energy Agency, p. 219-232.

Harshman, E. N., 1972, Geology and uranium deposits, Shirley Basin area, Wyoming: U. S. Geological Survey Professional Paper 745, 82 p.

Harshman, E. N., 1974, Distribution of elements in some rol1-type uranium deposits, in Formation of uranium ore deposits: Athens, International Atomic Energy Agency, p. 169-183.

Hart, 0. M., 1968, Uranium in the Black Hills, in Ridge, J. D., ed., Ore deposits of the United States, 1933-1967 (Graton-Sales volume): New York, American Institute of Mining, Metallurgy, and Petroleum Engineers, v. 1, p. 832-83.7.

Hart, P. E., Duda, R. 0., Einaudi, M. T., 1978, Prospector--a computer-based consultation system for mineral exploration: Journal of the International Association for Mathematical Geology, v. 10, no. 5, p. 589-610. 
Hay, R. L., 1963, Stratigraphy and zeolitic diagenesis of the John Day Formation of Oregon: California University, Publications of Geological Sciences, v. 42, p. 199-262.

Haynes, R. W., 1975, Beverley sedimentary uranium ore body, Frome Embayment, South Australia, in Knight, C. L., ed., Economic Geology of Australia and Papua New Guinea, I. Metals: Australian Institute of Mining and Metallurgy, Monograph No. 5, Victoria, Australia, p. 808-813.

Hemley, J. J., and Jones, W. R., 1964, Chemical aspects of hydrothermal alteration with emphasis on hydrogen metasomatism: Economic Geology, v. 59, p. $538-567$.

Hostetler, P. B., and Garrels, R. M., 1962, Transportation and precipitation of uranium and vanadium at low temperatures, with special reference to sandstone-type uranium deposits: Economic Geology, v. 57, p. 137-167.

Houston, R. S., 1969, Aspects of the geologic history of Wyoming related to the formation of uranium deposits: Wyoming University Contributions to Geology, v. 8, p. 67-79.

Jensen, M. L., 1958, Sulfur isotopes and the origin of sandstone-type uranium deposits: Economic Geology, v. 53, p. 598-616.

Kashirtseva, M. F., 1964, Mineralic and chemical zonality in uranium infiltration ore occurrences: Sovetskaya Geologiya, no. 10, p. 51-65.

Keefer, W. R., 1970, Structural geology of the Wind River Basin, Wyoming: U. S. Geological Survey Professional Paper 495-D, 35 p.

King, J.W., and Austin, S. R., 1965, Some characteristics of rol1-type uranium deposits at Gas Hills, Wyoming: U. S. Atomic Energy Commission Workshop Paper No. 7.

King, J. W., and Austin, S. R., 1966, Some characteristics of rol1-type uranium deposits at Gas Hills, Wyoming: Mining Engineers, v. 18, no. 5 , p. 73-80.

Kochenov, A. V., Zinevyev, V. V., and Lovaleva, S. A., 1965, Some features of the accumulation of uranium in peat bogs: Geochemists International, v. 2 , n. 1 , p. 65-70.

Kreitler, C. W., 1979, Ground-water hydrology of depositional systems, in Depositional and ground-water flow systems in exploration for uranium: Austin, Texas, University of Texas, Bureau of Economic Geology, p. 118-176.

Lakin, H. W., 1961, Geochemistry of selenium in relation to agriculture, in Selenium in agriculture: U. S. Department of Agriculture Handbook $2 \overline{00}$, p. 3-12.

Langen, R. E., and Kidwe11, A. L., 1974, Geology and geochemistry of the llighland uranium deposit, Converse County, Wyoming: Mountain Geologist, v. 11 , no. 2 , p. 85-93. 
Langmuir, D., and Applin, K., 1977, Refinement of the thermodynamic properties of uranium minerals and dissolved species, with application to the chemistry of ground waters in sandstone-type uranium deposits, in Campbel1, J.A., ed., Short papers of the U. S. Geological Survey, Uranium-Thorium Symposium, 1977: U. S. Geological Survey Circular 753, $75 \mathrm{p}$.

Lindgren, W., Graton, L. C., and Gordon, C. H., 1910, The ore deposits of New Mexico: U. S. Geological Survey Professional Paper 68, 361 p.

Lipman, P. W., Prostka, J. H., and Christiansen, R. L., 1972, Cenozoic vo1canism and plate-tectonic evolution of the Western United States. I--Early and Middle Cenozoic: Philosophical Transactions of the Royal Society of London, v. 271, p. 217-248.

Lisitsyń, A. K., and Kuznetsova, E. C., 1967, Role of micro-organisms in development of geochemical reduction barriers where limonitization bedded zones wedge-out: International Geology Review, v. 9, no. 9, p. 1180-1191.

Lisitsyn, A. K., 1969, Conditions of molybdenum and selenium deposition in exogenous epigenetic uranium deposits: Lithology and Mineral Resources (translated from Russian) 5, p. 542.

Love, J. D., 1970, Cenozoic geology of the Granite Mountains area, central Wyoming: U. S. Geological Survey Professional Paper 495-C, p. C1-C154.

Ludwig, K. R., 1978, Uranium-daughter migration and U/Pb isotope apparent ages of uranium ores, Shirley Basin, Wyoming: Economic Geology, v. 73, p. 29-49.

Ludwig, K. R., 1979, Age of uranium mineralization in the Gas Hills and Crooks Gap districts, Wyoming, as indicated by U-Pb isotope apparent ages: Economic Geology, v. 74, p. 1654-1668.

Masursky, H., 1962, Uranium-bearing coal in the eastern part of the Red Desert area, Wyoming: U. S. Geological Survey Bulletin 1099-B, p. B1-B152.

McGowen, J.H., 1979, Alluvial fan systems, in Depositional and ground-water flow systems in the exploration for uranium: Austin, Texas, University of Texas, Bureau of Economic Geology, p. 43-79.

Melin, R. E., 1964, Description and origin of uranium deposits in Shirley Basin, Wyoming: Economic Geology, v. 59, p. 835-849.

Melin, R. E., 1969, Uranium deposits in Shirley Basin, Wyoming: Wyoming University Contributions to Geology, v. 8, p. 143-149.

Mickle, D. G., 1978, A preliminary classification of uranium deposits: U. S. Department of Energy GJBX-63(78), Grand Junction, Colorado, 78 p.

Mickle, D. G., and Mathews, G. W., 1978, Geologic characteristics of environments favorable for uranium deposits: U. S. Department of Energy, GJBX-67(78), Grand Junction, Colorado, 250 p. 
Mrak, V. A., 1968, Uranium deposits in the Eocene sandstones of the Powder River Basin, Wyoming, in Ridge, J. D., ed., Ore deposits of the United States, 1933-1967 (Graton-Sales volume): New York, American Institute of Mining, Metallurgy, and Petroleum Engineers, v. 1, p. 838-848.

Pipiringos, G. N., and Denson, N. M., 1970, The Battle Spring Formation in south-central Wyoming: Wyoming Geological Association, 22nd Field Conference Guidebook, p. 161-168.

Rackley, R. I., 1972, Environment of Wyoming Tertiary uranium deposits: American Association of Petroleum Geologists Bulletin, v. 56, p. 755-774.

Rackley, R. I., 1976, Origin of western-states type uranium mineralization, in Handbook of strata-bound and stratiform ore deposits, H. K. Wolf, ed.: Amsterdam, Elsevier Scientific Publishing Co., p. 89-156.

Rackley, R. I., Shockey, P. N., and Dahill, M. P., 1968, Concepts and methods of uranium exploration: Wyoming Geological Association, 20th Field Conference Guidebook, p. 115-124.

Reade, H. J., Jr., 1976, Grover uranium deposit: a case history of uranium exploration in the Denver Basin, Colorado: Mountain Geologist, v. 13, no. 1 , p. 21-31.

Renfro, A. R., 1969, Uranium deposits in the Lower Cretaceous of the Black Hills: Wyoming University Contributions to Geology, v. 8, p. 87-92.

Robinson, C. S., Mapel, W. J., and Bergendahl, M. H., 1964, Stratigraphy and structure of the northern and western flanks of the Black Hills uplift, Wyoming, Montana, and South Dakota: U. S. Geological Survey Professional Paper 404, 134 p.

Rosholt, J. N., Zartman, R. E., and Nkomo, I. T., 1973, Lead isotope systematics and uranium depletion in the Granite Mountains, Wyoming: Geological Society of America Bulletin, v. 84, p. 989-1002.

Ruzlcka, V., 1976, Uranium resources evaluation model as an exploration tool, in Exploration for uranium ore deposits: Vienna, International Atomic Energy Agency, p. 673-682.

Ryan, J. D., 1964, Geology of the Edgemont quadrangle, Fall River County, South Dakota: U. S. Geological Survey Bulletin 1063-J, p. 379-426.

Schmidt-Collerus, J. J., 1969, Part II, Experimental investigations, of Investigations of the relationship between organic matter and uranium deposits: Atomic Energy Commission Open-File Report GJ0-933-2, 192 p.

Schmidt-Collerus, J. J., 1979, Investigation of the relationship between organic matter and uranium deposits: U. S. Department of Energy GJBX-130(79), Bendix Field Engineering Corporation, 281 p. 
Sharp, W. N., and Gibbons, A. B., 1964, Geology and uranium deposits of the southern part of the Powder River Basin, Wyoming: U. S. Geological Survey Bulletin 1147-D, p. D1-D60.

Sharp, W. N., McKay, E. J., McKeown, F. A., and White, A. M., , 1964, Geology and uranium deposits of the Pumpkin Buttes area of the Powder River Basin, Wyoming: U. S. Geological Survey Bulletin 1107-H, p. 541-638.

Sherborne, J. E., Jr., Pavlak, S. J., Peterson, C. H., Buckovic, W. A., 1980, Uranium deposits of the Sweetwater Mine area, Great Divide Basin Wyoming, in Third annual uranium seminar: New York, American Institute of Mining, Metallurgy, and Petroleum Engineers, p. 27-37.

Sheridan, D. M., Maxwe11, C. H., and Col1ier, J. T., 1961, Geology of the Lost Creek Schroeckingerite deposits, Sweetwater County, Wyoming: U. S. Geological Survey Bulletin 1087-J, p. 391-478.

Singer, D. A., and Ovenshine, A. T., 1979, Assessing Alaska's metal resources: American Scientist, v. 57, no. 5, p. 582-589.

Soister, P. E., 1968, Stratigraphy of the Wind River Formation in southcentral Wind River Basin, Wyoming: U. S. Geological Survey Professiona1 Paper 594-A, p. 50.

Stephens, J. G., 1964, Geology and uranium deposits at Crooks Gap, Fremont County, Wyoming: U. S. Geological Survey Bulletin 1147-F, p. F1-F82.

Stuckless, J. S., and Nkomo, I. T., 1978, Uranium-lead isotope systematics in uraniferous alkali-rich granites from the Granite Mountains, Wyoming: implications for uranium source rocks: Economic Geology, v. 73, p. 427-441.

Thode, H. G., Kleerekoper, H., and McElcheren, D., 1951, Isotopic fractionation in the bacterial reduction of sulfate: Research (London), v. 4, p. 581-582.

Tweto, 0., 1975, Laramide (Late Cretaceous-Early Tertiary) orogeny in the southern Rocky Mountains: Geological Society of America Memoir 144, p. 1-43.

Van Houten, F. B., 1964, Tertiary geology of the Beaver Rim area, Fremont and Natrona Counties, Wyoming: U. S. Geological Survey Bulletin 1164, 99 p.

Vickers, R. C., 1957, Alteration of sandstone as a guide to uranium deposits and their origin, northern Black Hills, South Dakota: Economic Geology, v. 52, p. 599-611.

Vine, J. D., and Tourtelot, E. B., 1970, Preliminary geochemical and petrographic analysis of Lower Eocene fluvial sandstones in the Rocky Mountain region: Wyoming Geological Association, 22nd Field Conference Guidebook, p. 251-263. 
Voelker, A. H., Wedow, H., Oakes, E., and Scheffler, P. K., 1979, A systematic method for resource rating with two applications to potential wilderness areas: Oak Ridge National Laboratory, Oak Ridge, Tennessee, ORNL/TM-6739, $65 \mathrm{p}$.

Vredenburgh, L. D., and Cheney, E. S., 1971, Sulfur and carbon isotopic investigation of petroleum, Wind River Basin, Wyoming: American Association of Petroleum Geologists Bulletin, v. 55, no. 11, p. 1954-1975.

Waagé, K. M., 1959, Stratigraphy of the Inyan Kara group in the Black Hills: U. S. Geological Survey Bulletin 1081-B, p. 11-90.

Warren, C. G., 1968, The synthesis of ferroselite from aqueous solution at low temperature: Economic Geology, v. 63, p. 418-419.

Warren, C. G., 1971, A method of discriminating between biogenic and chemical origins of the ore-stage pyrite in a roll-type uranium deposit: Economic Geology, v. 66, p. 919-928.

Warren, C. G., 1972, Sulfur isotopes as a clew to the genetic geochemistry of a rol1-type uranium deposit: Economic Geology, v. 67, p. 759-767.

Weimer, R. J., 1973, A guide to uppermost Cretaceous stratigraphy, central Front Range, Colorado: Deltaic sedimentation, growth faulting, and early Laramide crustal movement: Mountain Geologist, v. 10, no. 3, p. 53-97.

Zielinski, R. A., 1980, Uranium in secondary silica: a possible exploration guide: Economic Geology, v. 75, no. 4, p. 592-602. 